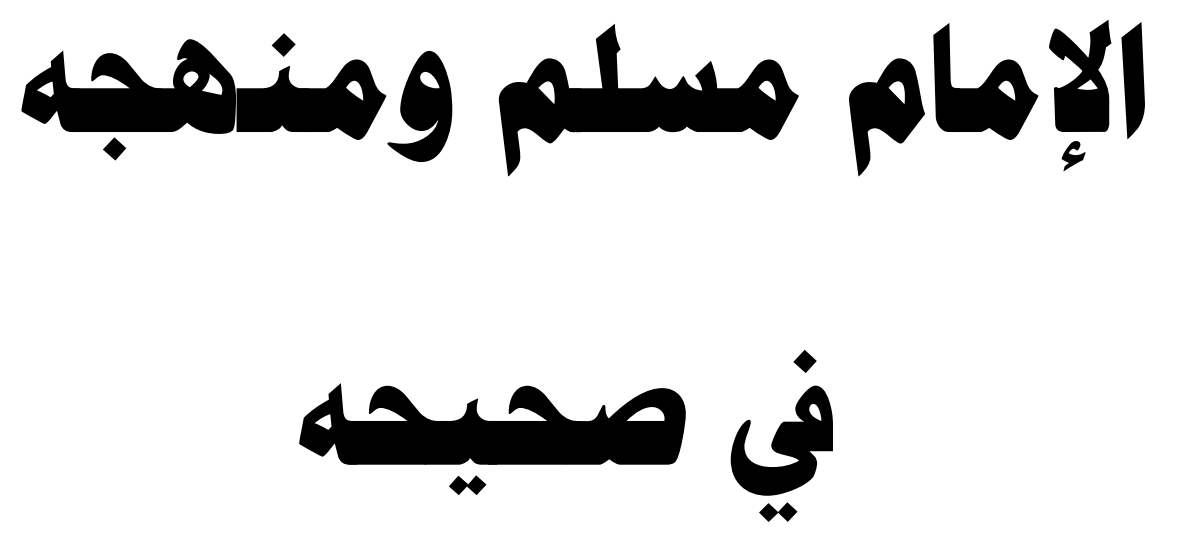

$$
\begin{aligned}
& \text { تأليف } \\
& \text { دكتورة / أمينة السيد حامد النادي } \\
& \text { ملدرس بقسيم الحليث وعلومه }
\end{aligned}
$$




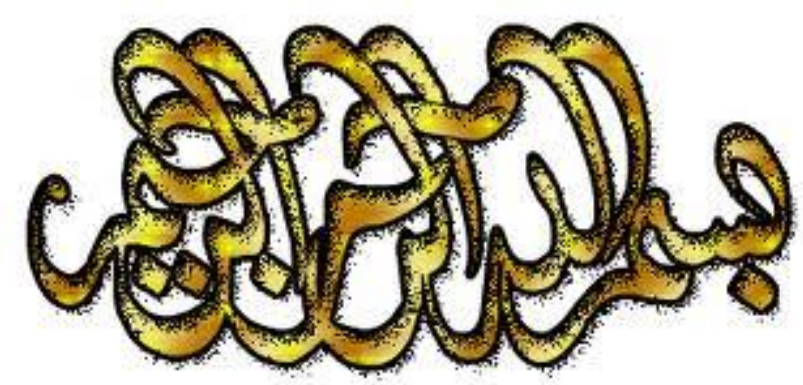

الحمد لله ، نحمده ونستعينه ونستففره، ونعوذ بالله من شرور أنفسنا ومن سيئات

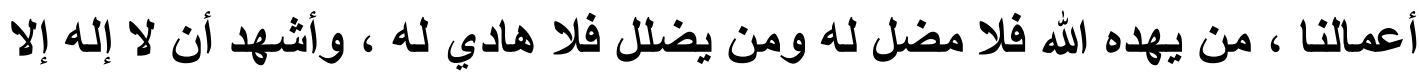

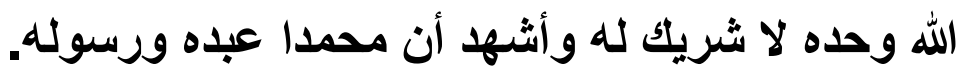
وبعد.......'

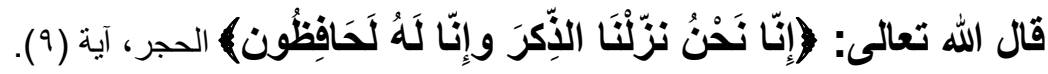
ان الدراسات المتعلقة بمناهج المحثثين تعد من الدراسات الحديثة و

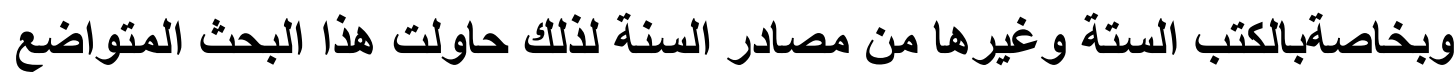

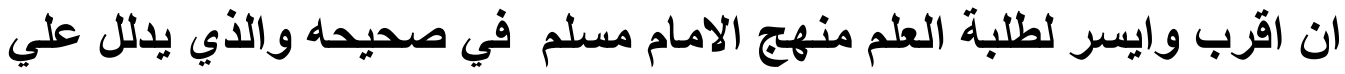
عبقرية الامام مسلم في ترتيب صحيحه وظهور الصناعة الحديثة في احاديثه وقد قسمته الي مقدمة ومبحثين ذكرت في المقدمة صورة اجماليةلموضوع البحث

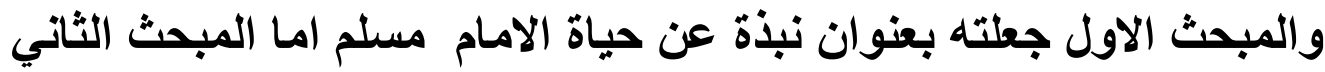

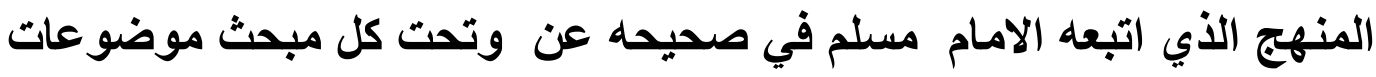
تثعلق به.

سائلة المولى عز وجل أن يشرح صدرنا و يعينتا و ييسر أمرنا و يوفقنا لاتمام

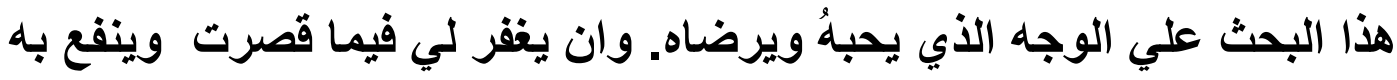

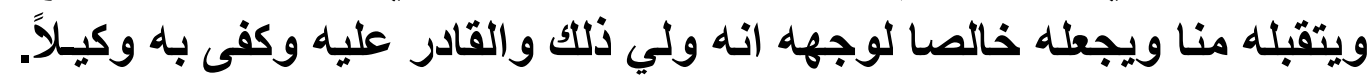

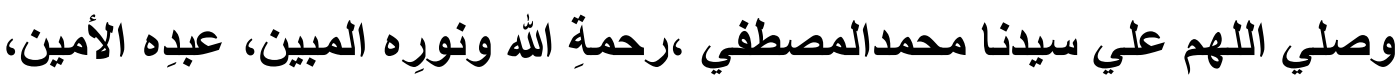

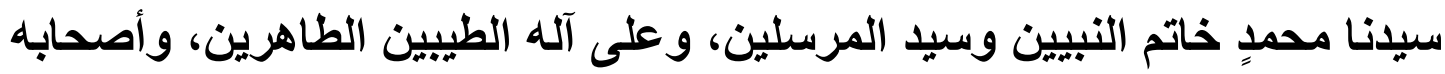

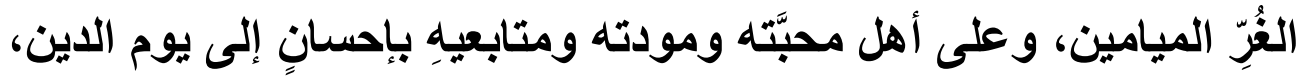


=

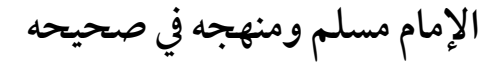

المبحث الأول

نبذة عن حياة الامام مسلم رحمه الله 
المطلب الاول اسمه ونسبه ونشاته

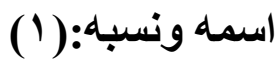

هو الإمام الكبيز الحافظ المجوّد الحجّة الصادق احدّة احد اعمدة النهضة الحديثة في عصره الإمام

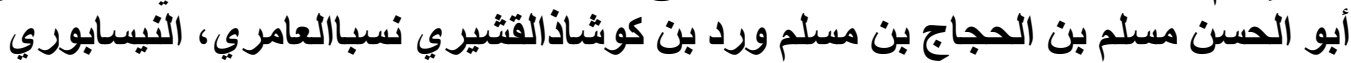

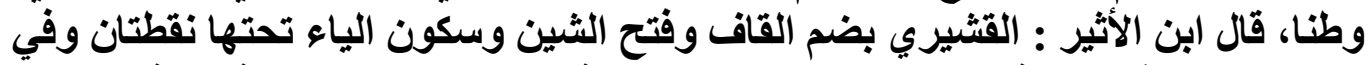

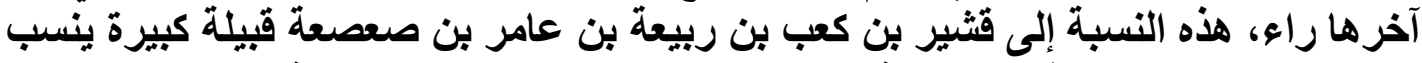

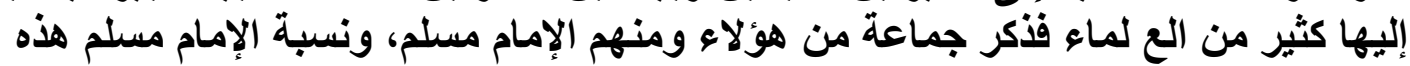

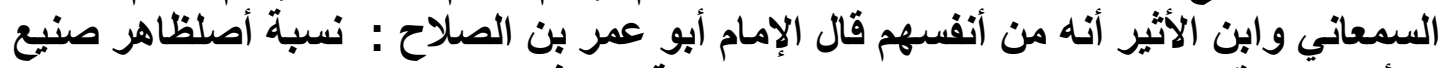

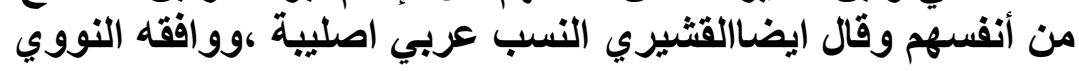

نيسابور هي مدينة في مقاطعةخراسان في شمال شرق ايران بالقرب من العاصمة الإقليمية

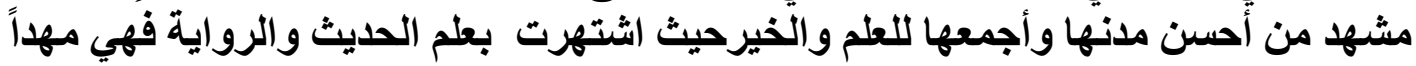

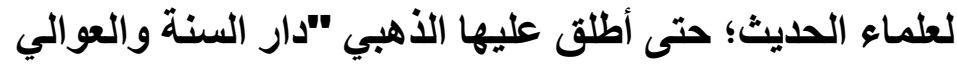

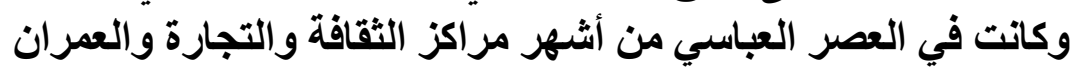

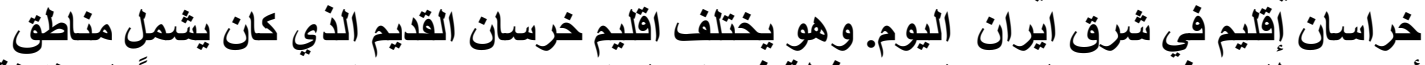

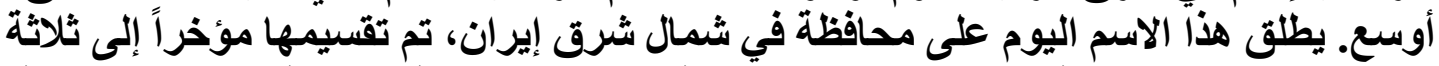

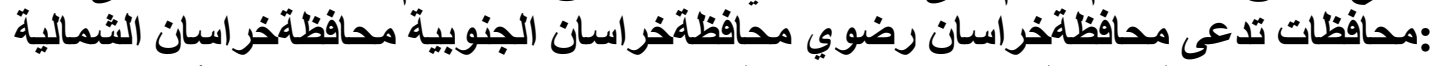

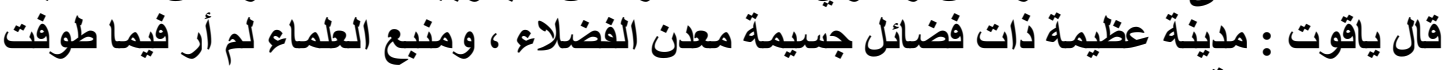

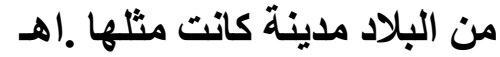

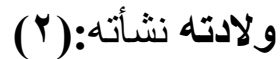
اختلف أهل العلم في مولده و لم يضبطه أحداً من الحفاظ و لكن وأجمعوا أنه ولا بعد المائتين

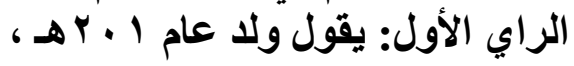

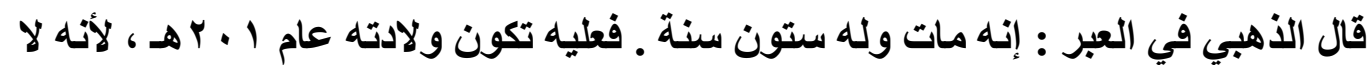

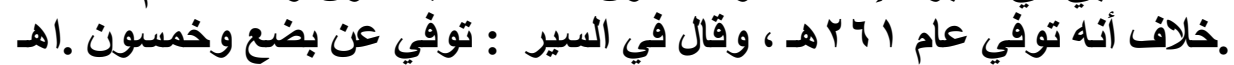

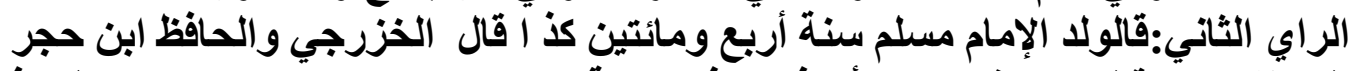

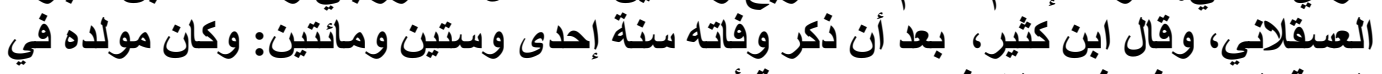
السنة التي توفي فيها الثافعي وهي سنة أنئ أربع ومائتين

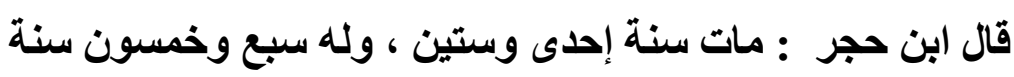

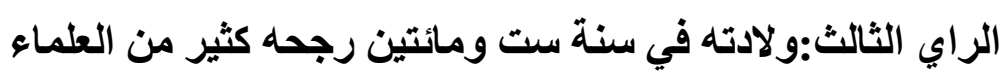

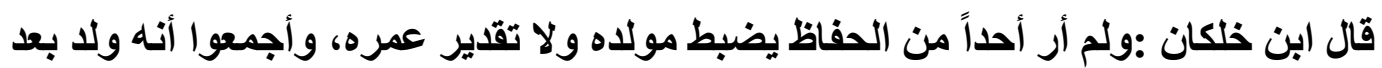

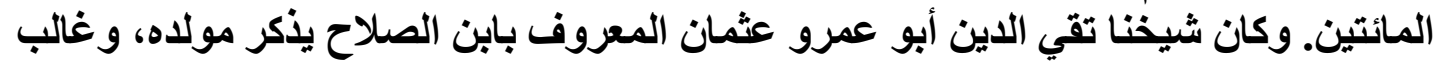

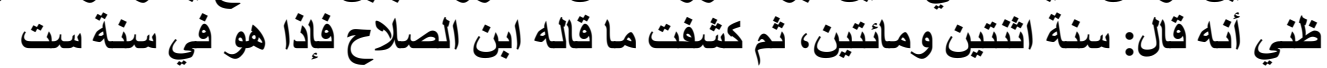
ومائتين، نقل ذلتك من كتاب

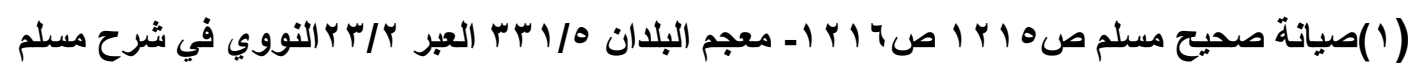
$|r| 1$

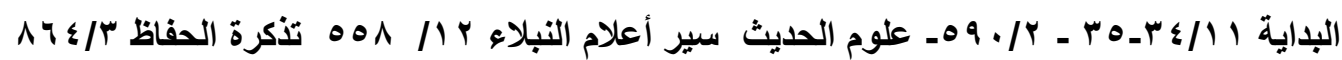

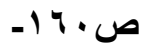

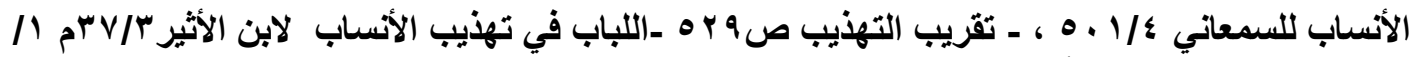

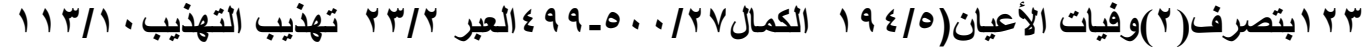




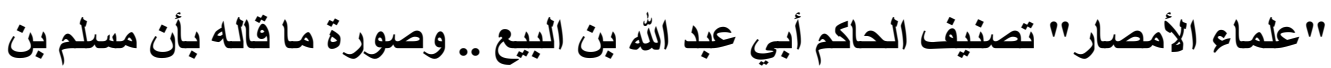

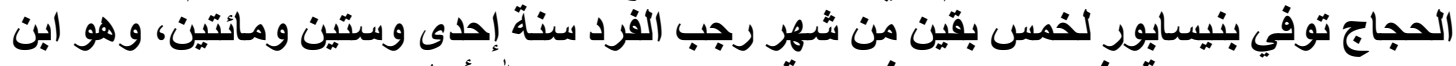

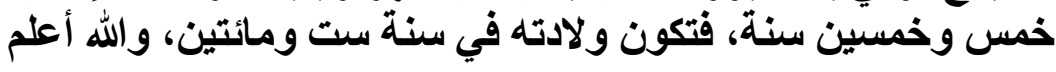

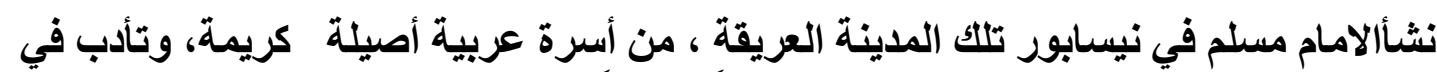

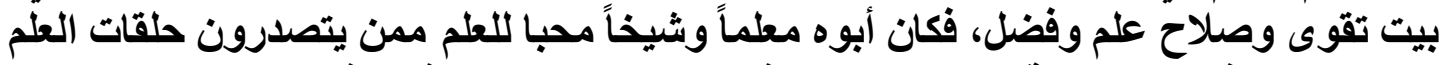

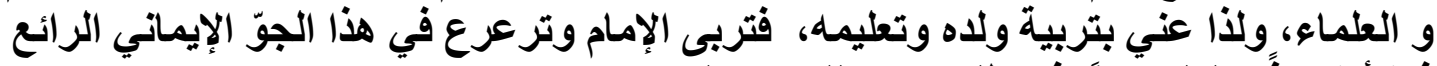

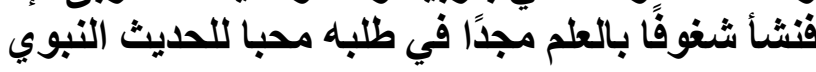

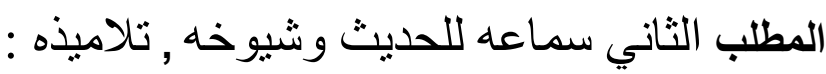
(1): مني بدا سماعه للحديث

بدألإمام مسلم رحمه الله رحلته في سماع الحديث و طلب العلم مبكرًا، سنة ثماني عشرة وماتثين

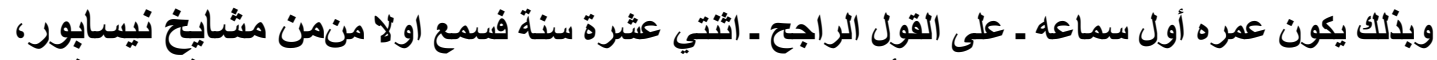

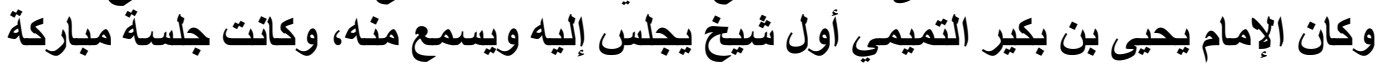

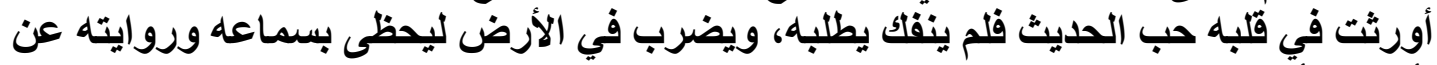

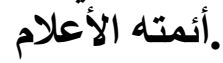
(r): شيوخها:

طاف الامام مسلم البلاد الإسلامية رحل إلى الحجاز والعراق وإئ والثام ومصر طلباً للعلم وسمع

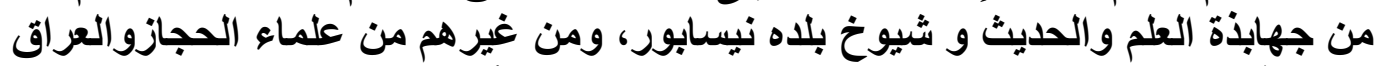

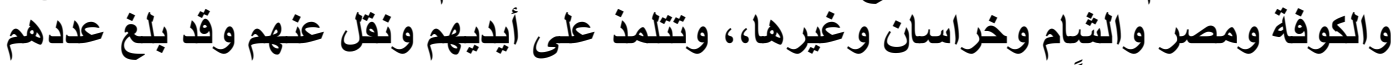
مئتان وعشرون رجلًا، فقد سمع بمكة من عبد الله بن مسلمة القعنبي، وهو يعدأكبر شيخ له، وسمع بالكوفة والعراق

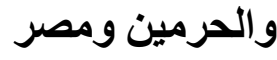
وأكثر من السماع عن محمد بن المثي الملقب الزمن ـقتيبة بن سعيد محمد بن حاتم الملقب

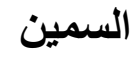

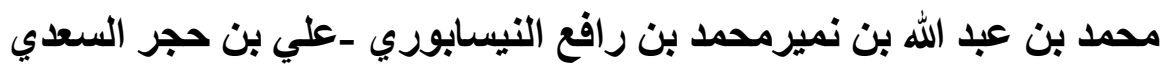

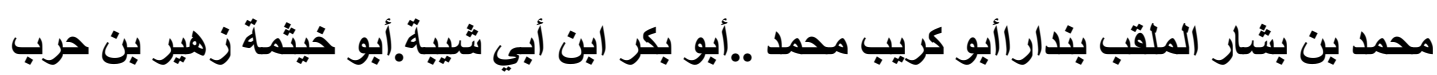

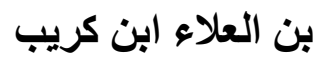

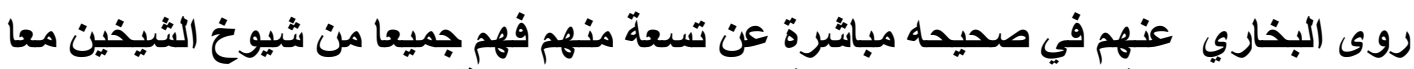

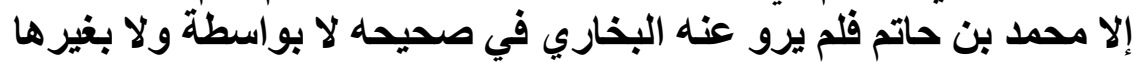

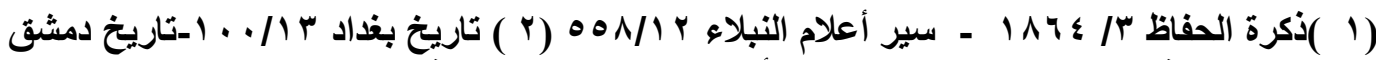

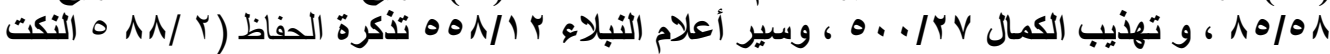

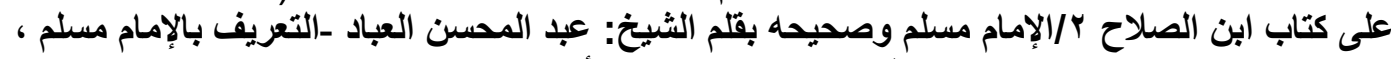

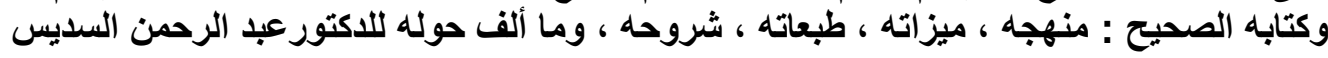




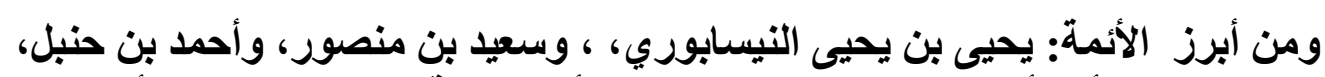

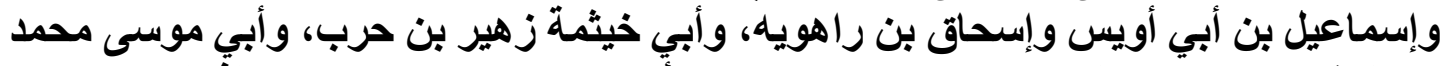

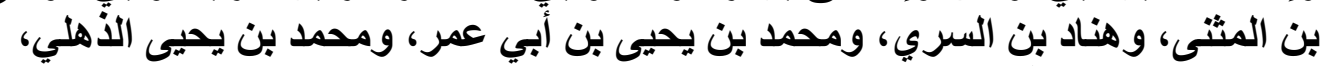

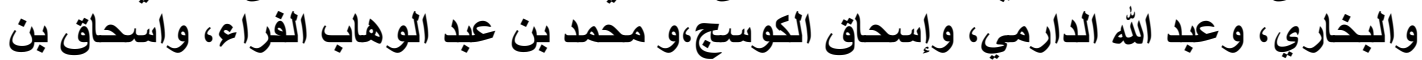

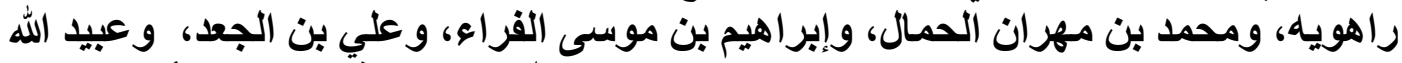

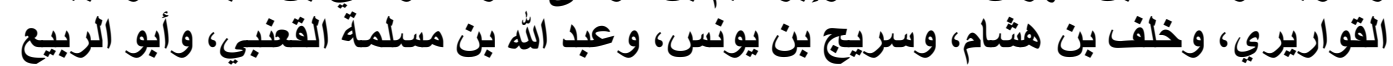

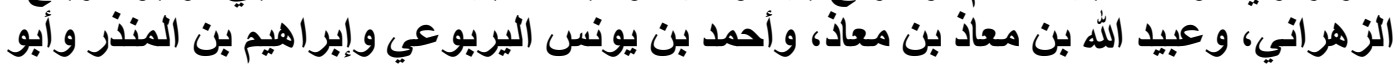

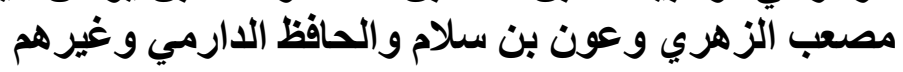

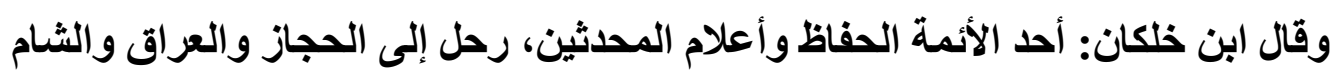

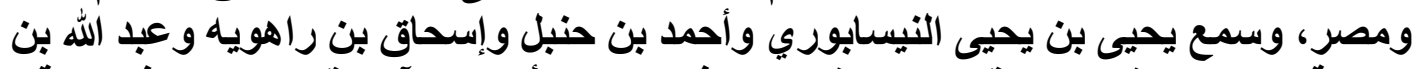

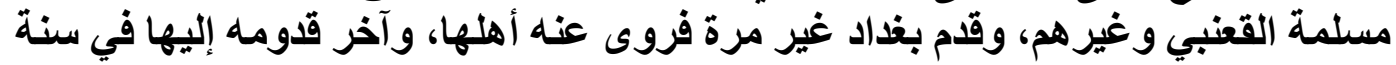

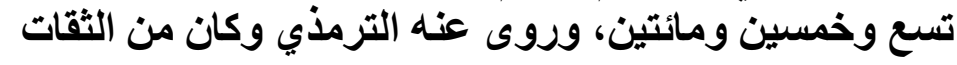

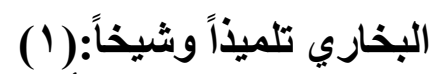

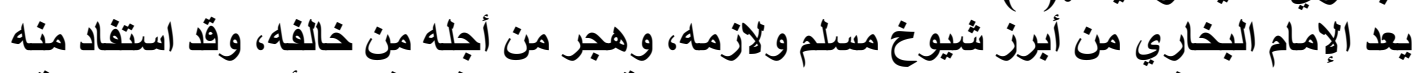

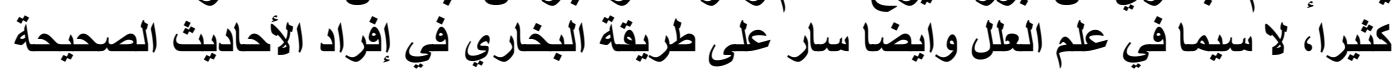

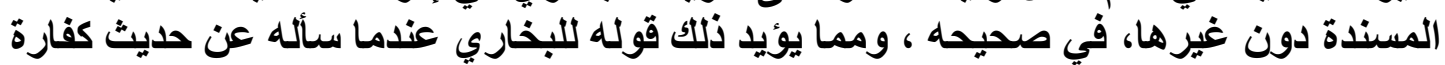

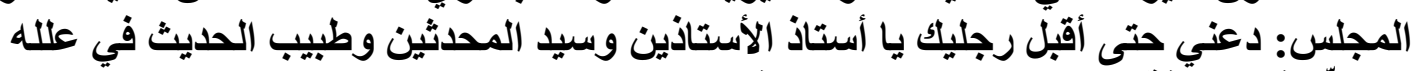

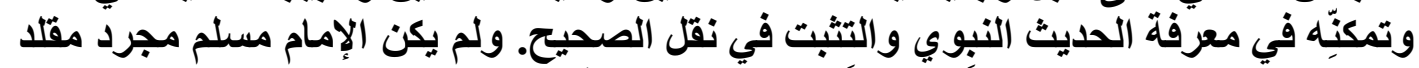

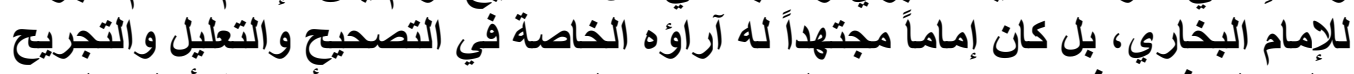

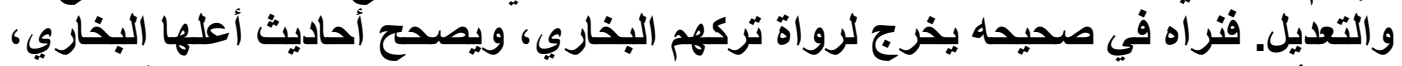

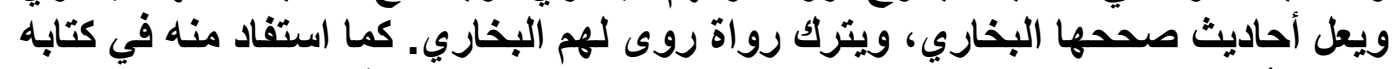

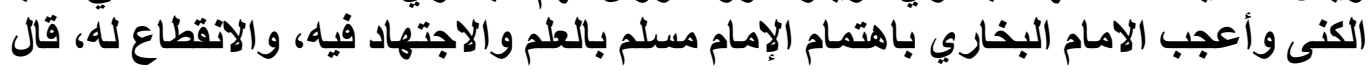

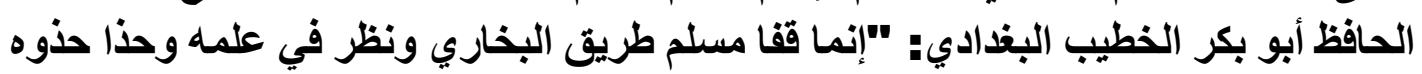

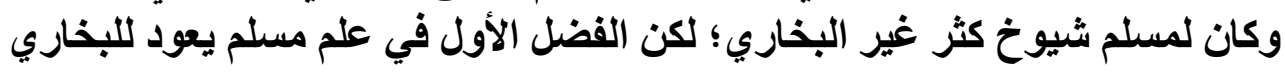

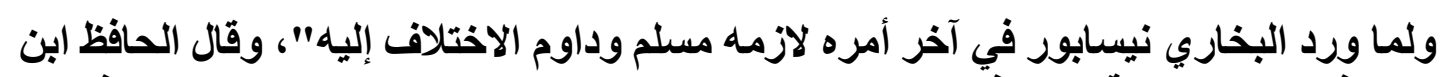

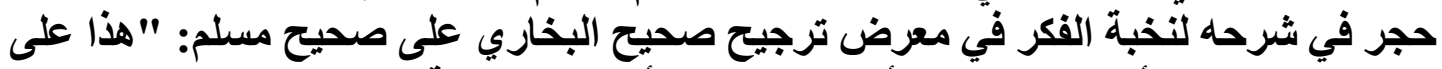

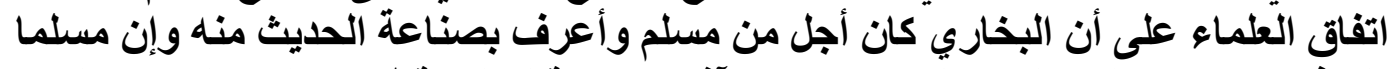

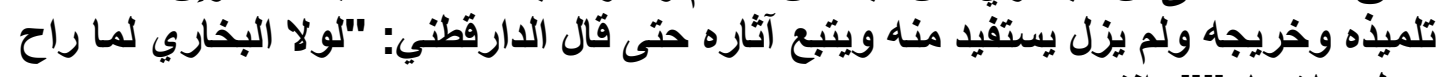

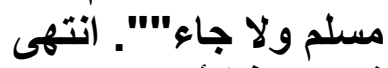

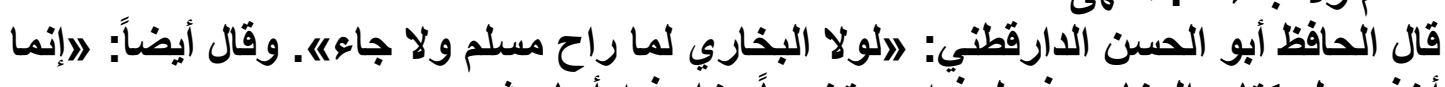

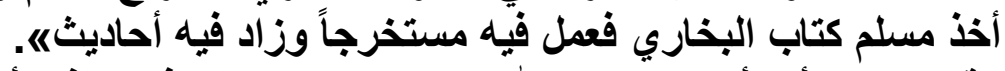

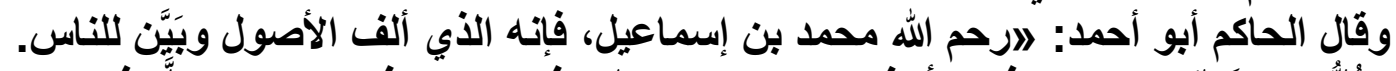

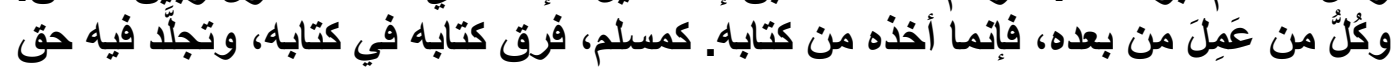

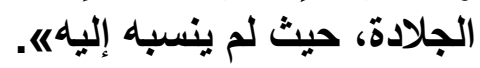

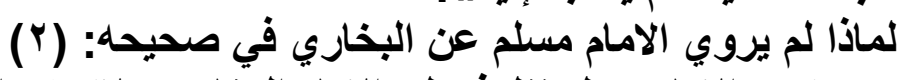

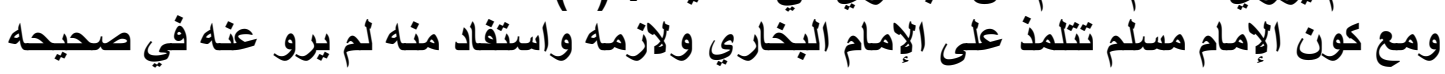
شيئا

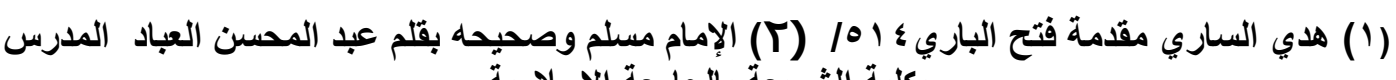
بكلية الثريعة بالجامعة الإسلامية 
ويبدو والله تعالى أعلم أن مسلما رحمه الله فعل ذلك لأمرين

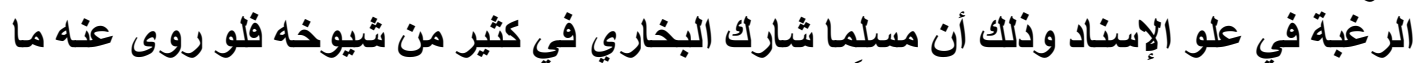

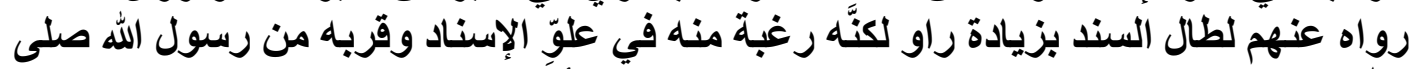

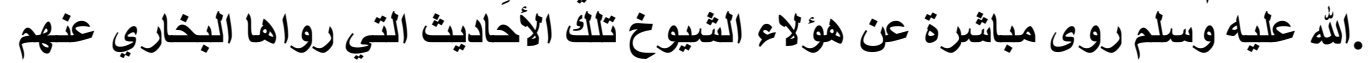
الثاني:

أن الإمام مسلما رحمه الله سـاءه ما حصل من بعض العلماء من مزج الأحاديث الضعيفة

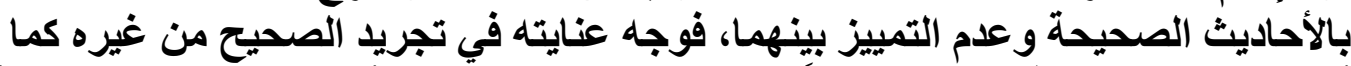

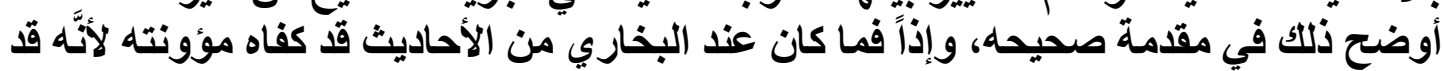

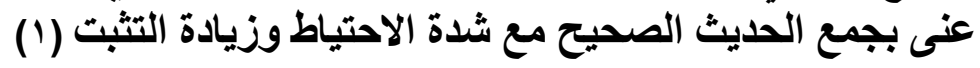

\section{(r) تلاميذه}

وقد تتلمذ وأخذ الحديث ، والعلم من الإمام مسلم تلاميذ كثيرون سمعوا منه منهم: أبو الفضل

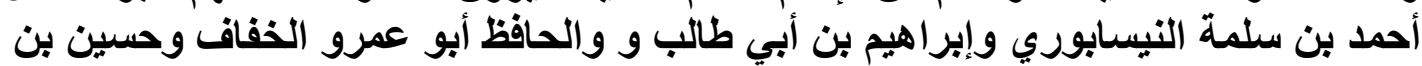

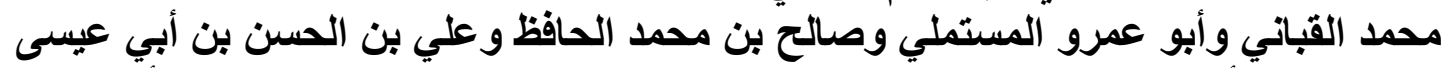

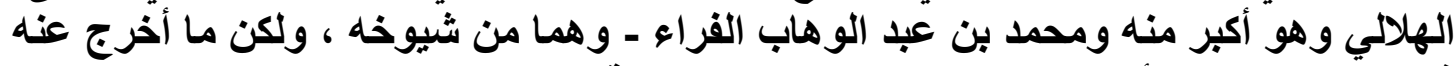

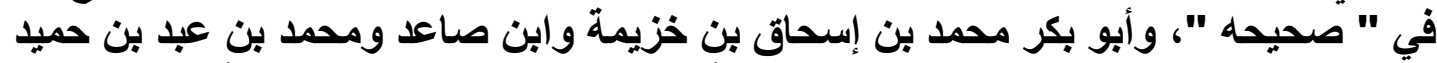

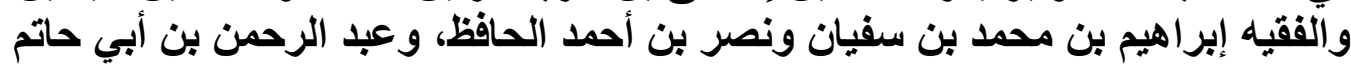

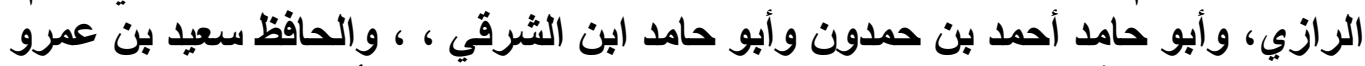

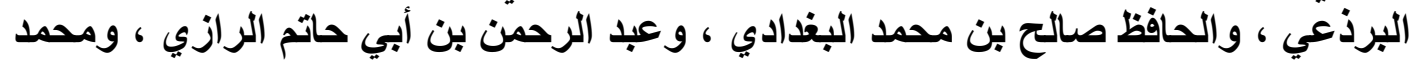

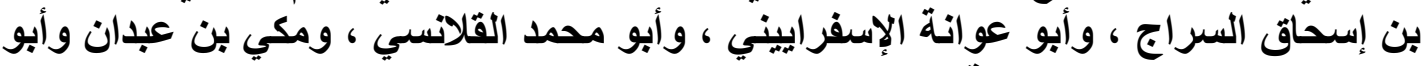

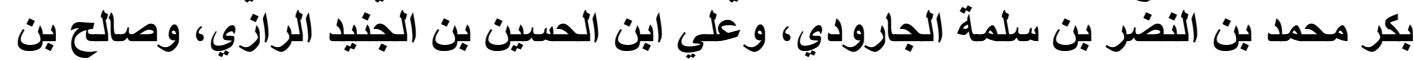

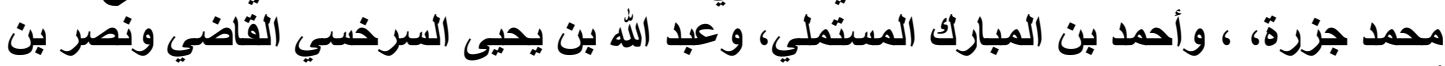

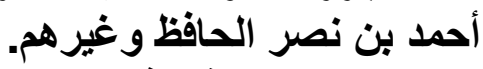

وروى عنه التزمذي في جامعه حديثا واحدا فئن أخرجه في كتاب الصيام باب ما جاء في إحصاء

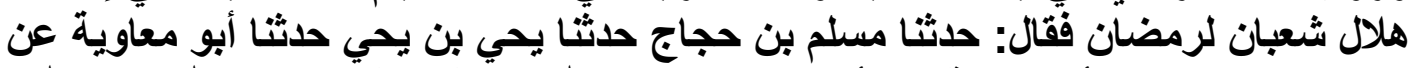

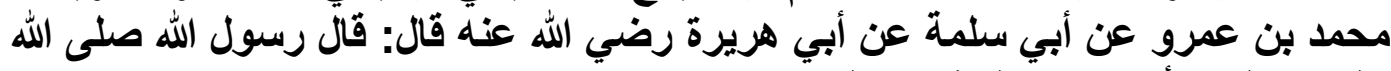

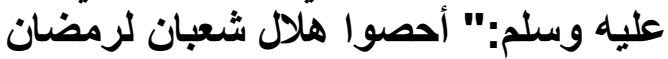

قال العراقي ـكما نقله عنه المباركفوري في تحفة الأحوذي-: "لم يرو المصنف في كتابه شيئا

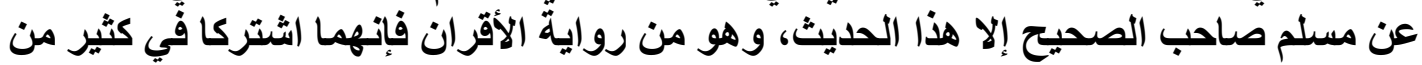

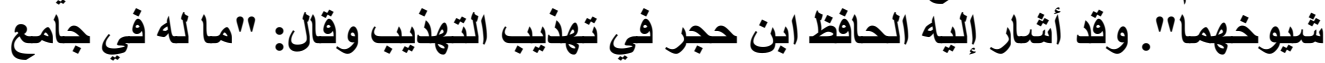

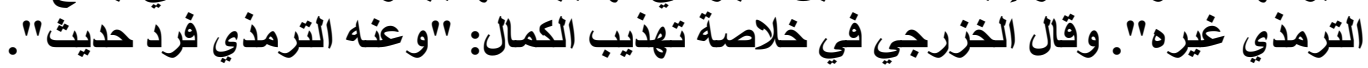

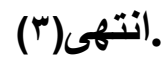

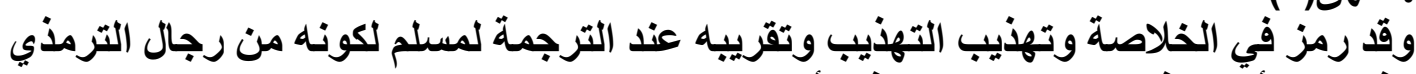
وذلك من أجل هذا الحديث الواحد الأي أخرجه

( ) عثرون حديثاً من صحيح مسلمدراسة أساتيدها وشرح متونها تأليفعبد المحسن بن حمد العباد

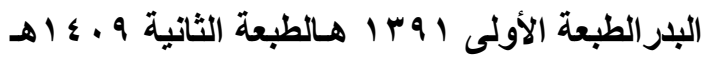

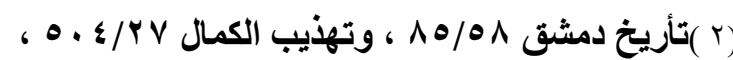

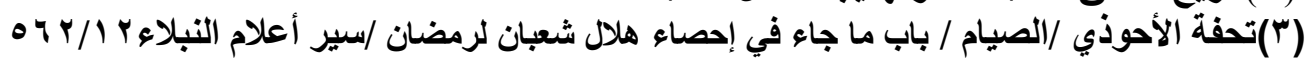


المطلب الثالث/ ثناء العلماء عليه وصفته الخلقية واهم ملامح شخصيته

(1) ثناء العلماء عليه: (1)

وبرغم ظهوره معاصراً لعدد من العلماء الأفذاذ فإن اجتهاده كان كفيلاً بوضعه بقوة موازياً

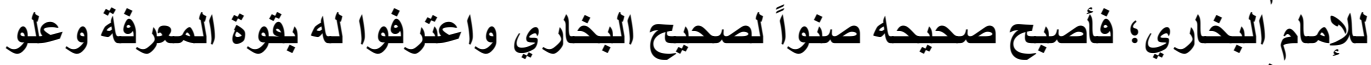

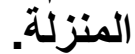
،و لقد فاضث ألسنة العلماء بعبارات التقدير والثناء على ألثى

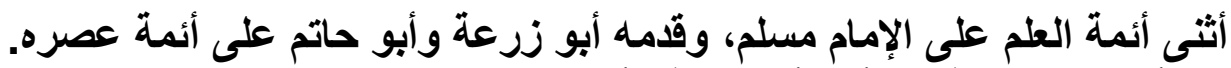

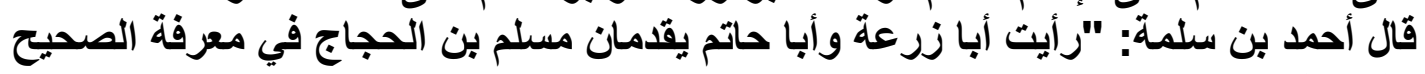

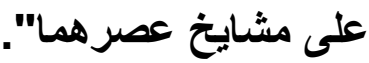

وقال شيخه محمد بن عبد الوهاب الفراء : كان مسلم من علماء الناس وأوعية العلم، ما علمته إلا خيراً،

$$
\text { وقال مسلمة بن قاسم : ثقة جليل القدر من الأئمة، }
$$

وقال النووي: أجمعوا على جلالته وإمامته، وعلو مرتبته وحذقه في الصنعة وتقدمه فيها

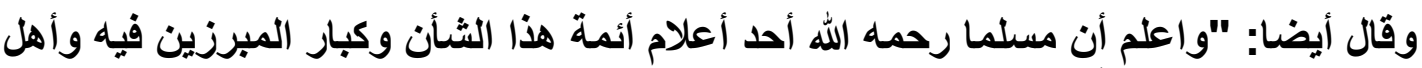

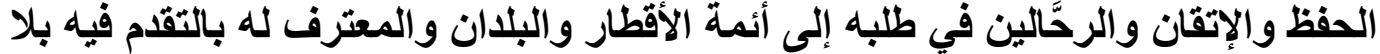

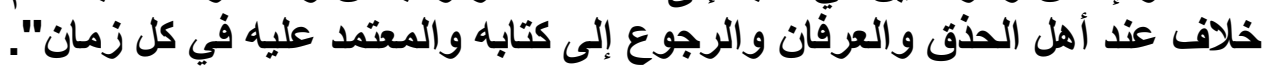

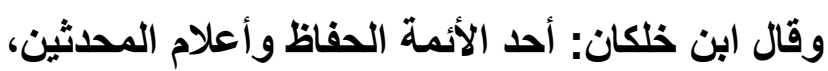

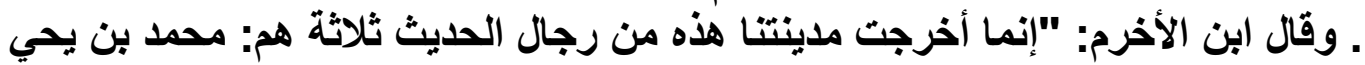

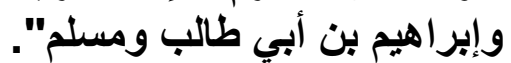

وقال ابن عقدة: "قلما يقع الغلط لمسلم في الرجال لأنه كتب الحديث على وجهه".

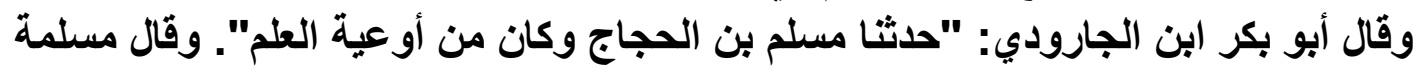
بن قاسم: "ثقة جليل القدر من الأيمة". وقال ابن أبي حاتم: "كتبت عنه، وكان ثقة من الحفاظ له معرفة في الحديث وسئل عنه أبي فقال صدوق"، وقال بندار: "الحفاظ أربعة أبو زرعة ومحمد بن إسماعيل والدارمي ومسلم". وقال إسحاق

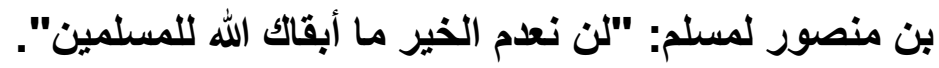
وقال أحمد بن سلمة: "رأيت أبا زرعة وأبا حاتم يقدمان مسلم بن الحجاج في معرفة الصحيح على مشايخ عصرهما".

وقال الذهبي في العبر: "أبو الحسين النيسابوري الحافظ أحد أركان الحديث".

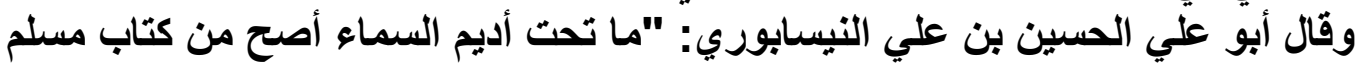
بن الحجاج في علم الحي الحيث بن عليث

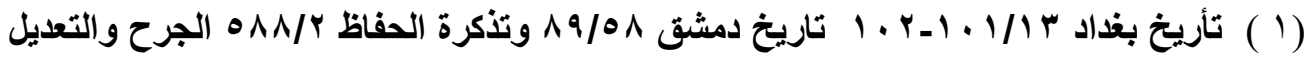


صفته الخلقية واهم ملامح شخصيته:

يُعدّ الإمـام مسلم أحد أعلام علم الحديث،شهد لله العلماء بكثرة علمهه وبراعته وبعلم الحديث

خاصة:

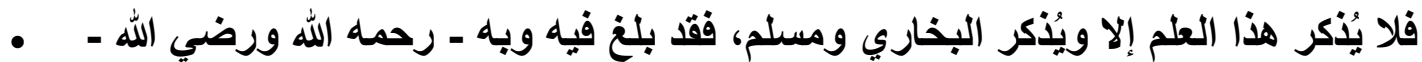

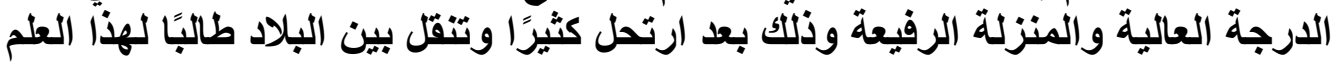

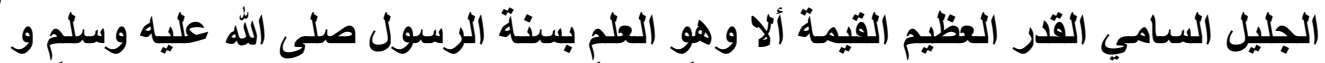

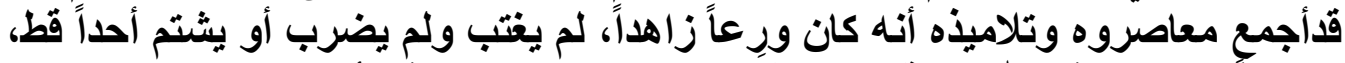

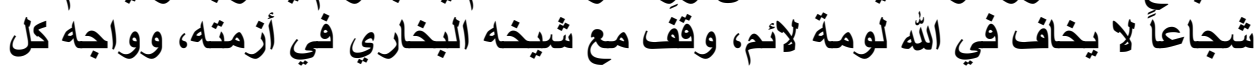

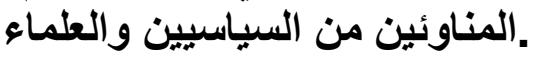

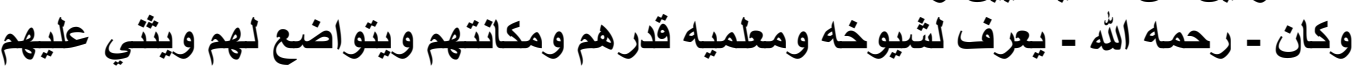

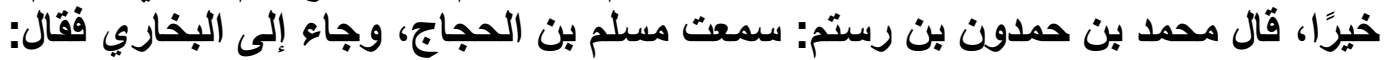

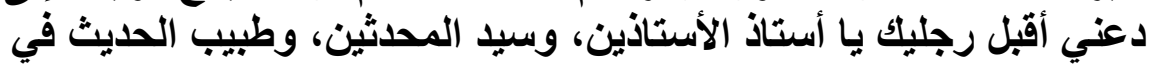

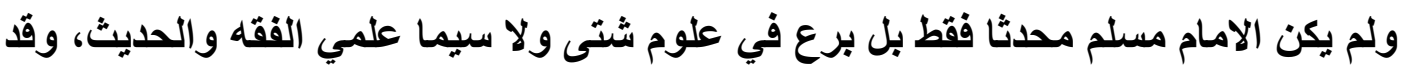

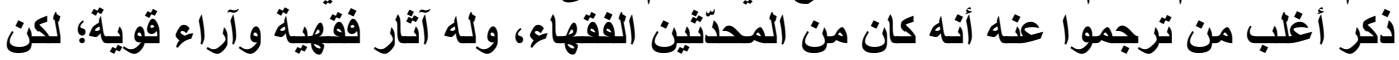

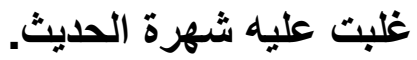

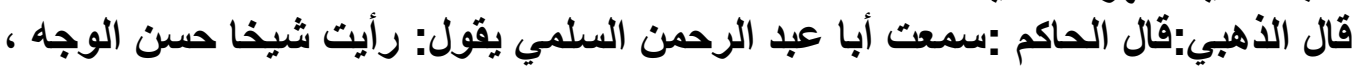

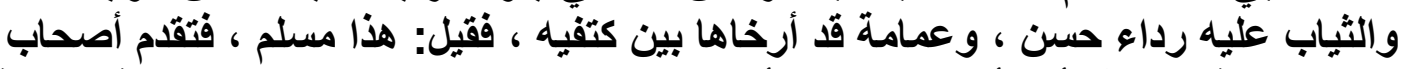

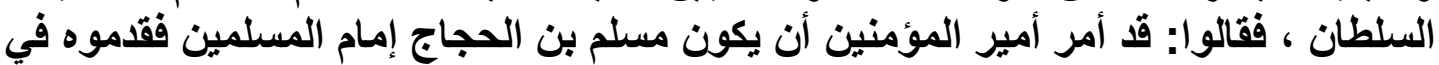

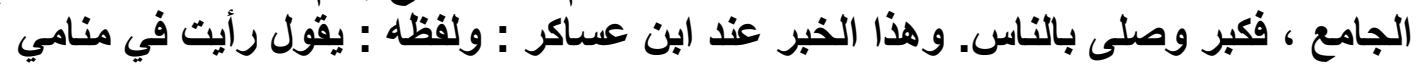
شيخا..

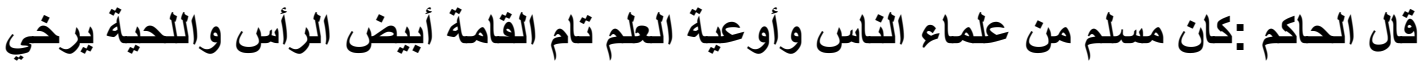

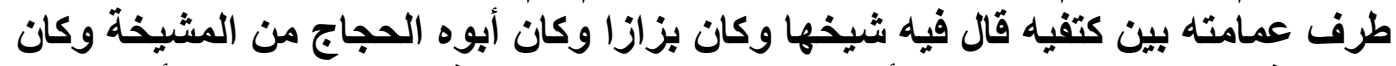

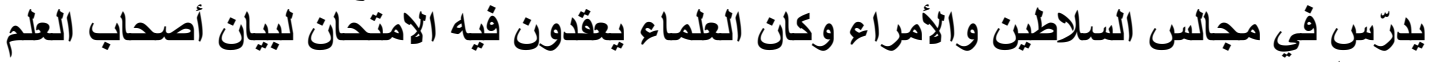
من مدّعيه.

ذكره الذهبي في كتابه ممن يعتمد قوله في الجرح والتعديل (

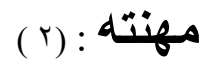

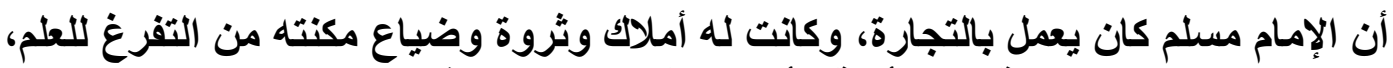

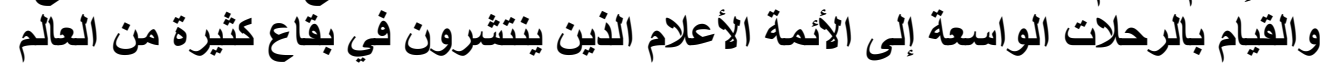

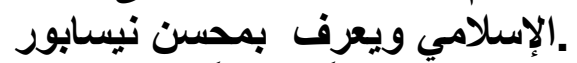

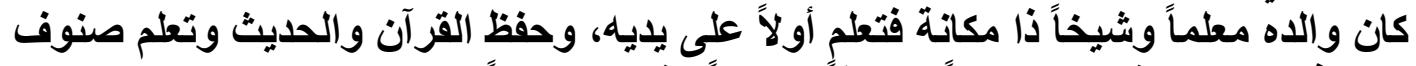

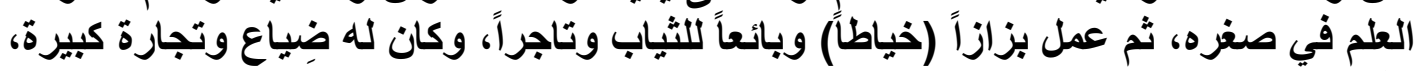
وقد سناعدته

ثروته على التقرّغ لطلب العلم؛ فحفظ القرآن وبدأ في سماع الحديث وعمره اثني عثرة سنة،

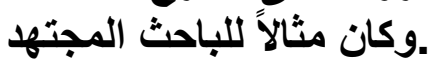
قال الذهبي في العبر:كان صاحب املاحك وثروة وكان محسن نيسابور

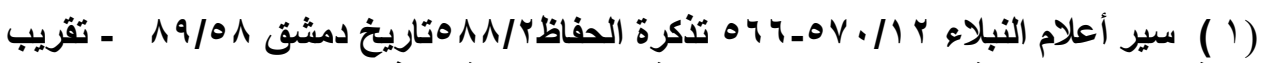

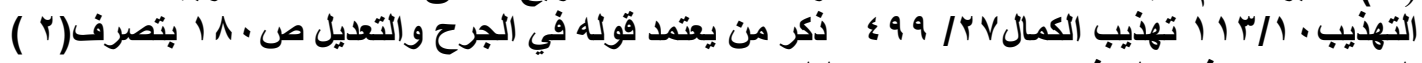

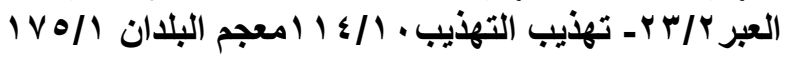


مؤلفاته: ( ) مون (1)

قال النووي في (تهذيب الأسماء واللغات): وصنّف مسلم - رحمه الله ـ في علم الحديث كتباً

ا ـ هذا الكتاب الصحيح r - ومنها الكتاب المسند الكبير على أسماء الرجال. (r) وكتاب الجامع الكبير على الأبواب.

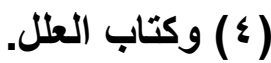
(0) وكتاب أوهام المحدثين.

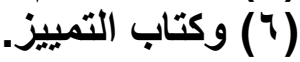

(V) وكتاب من ليس لله إلاب راو واحد. (V) (^) وكتاب طبقات (التابعين.

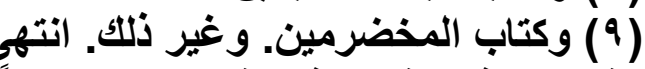
وذكر الحافظ الذهبي في تذكرة الحفاظ نقلاً عن الحاكم عشرين مؤلفاً لمسلم هي بالإضافة إلى ما تقدم.

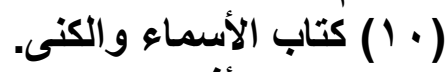

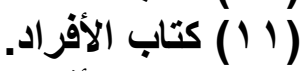

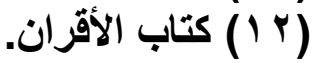

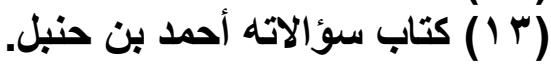

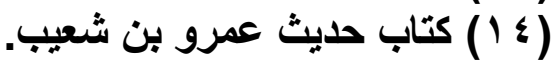
(10 (10) كتاب الانتفاع بأهب السباع.

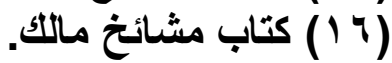
كتاب مشائخ الثوري. (IV) (1 ) كتاب مشائتخ شعبة.

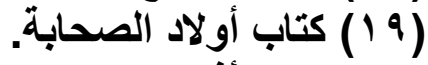

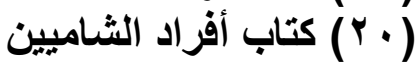

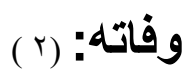

توفي الإمام مسلم رحمه الله عشية يوم الأحد ودفن يوم الاثنين لخمس بقين من رجب سنة

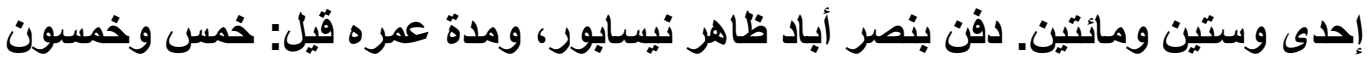

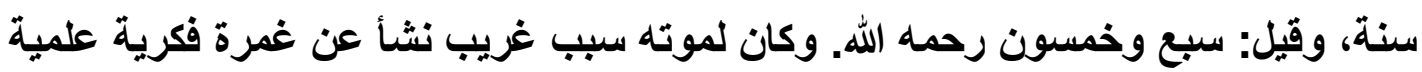

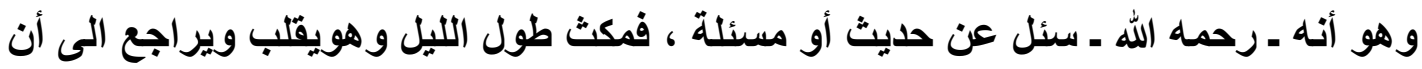

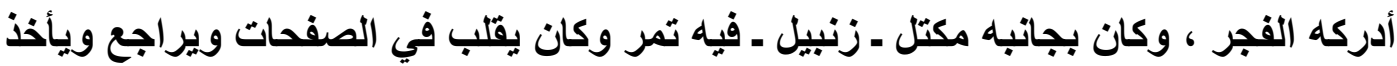

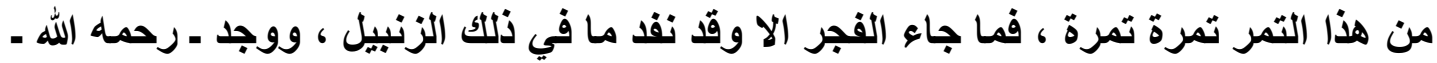

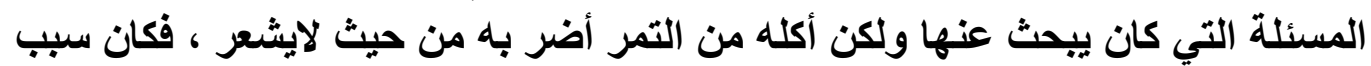

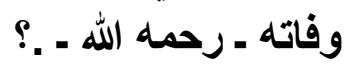

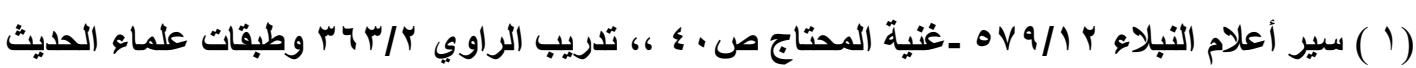

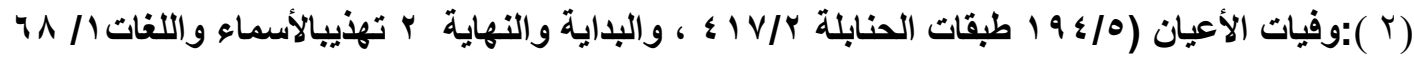

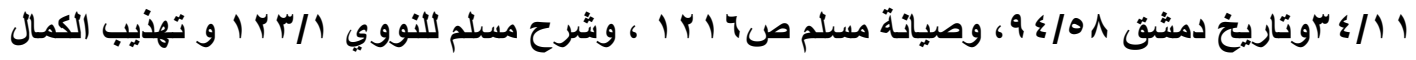




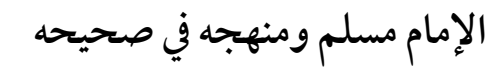

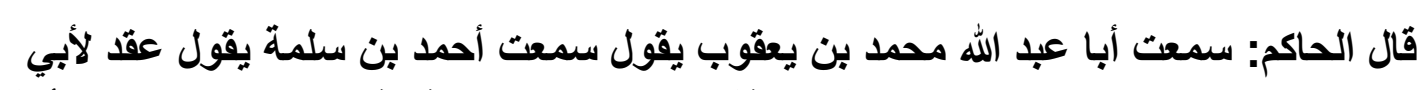

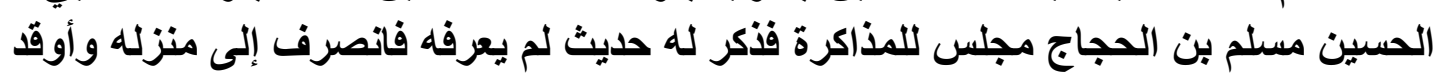

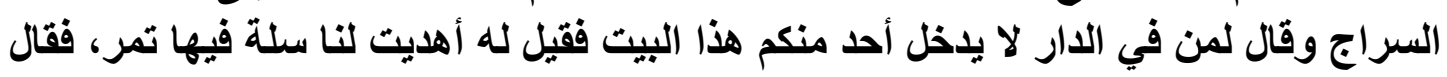

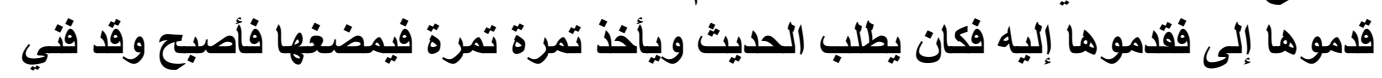

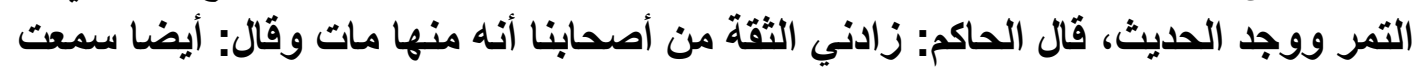

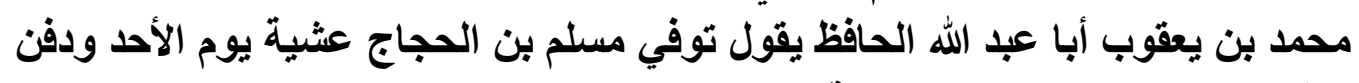

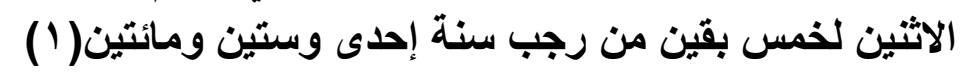

وقال ابن خلكان: وتوفي مسلم المذكور عشية يوم الأحد ودفن بنصر أباذ ظاهر نيسابور يوم

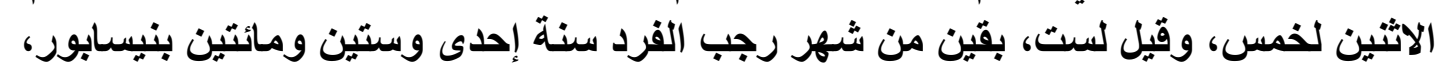

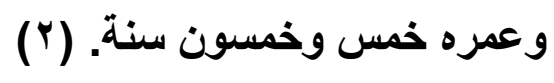




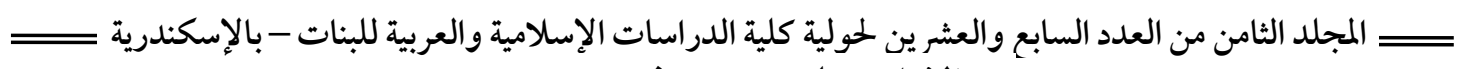

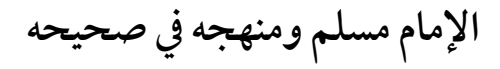

$$
\text { منهج الامام مسلم في الثاني }
$$




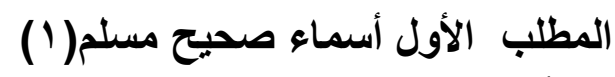

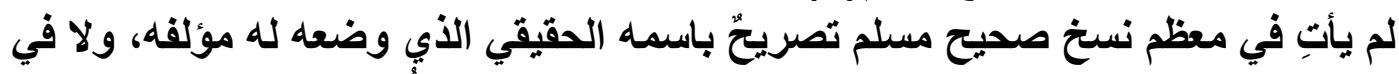

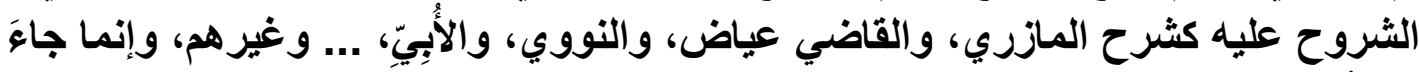

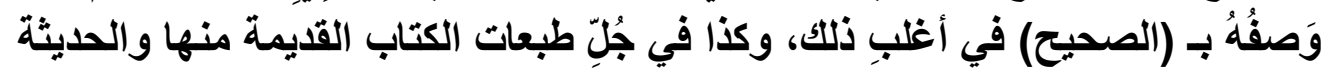

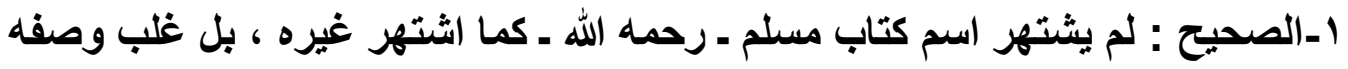

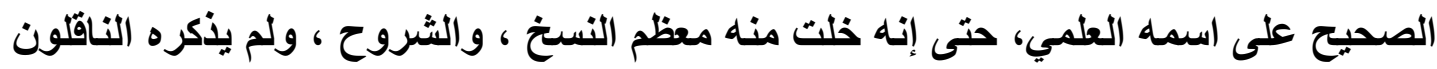

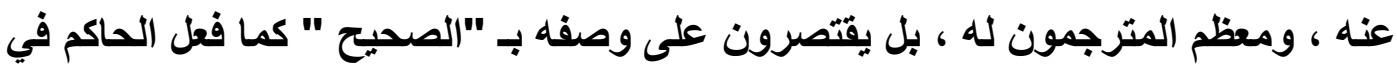

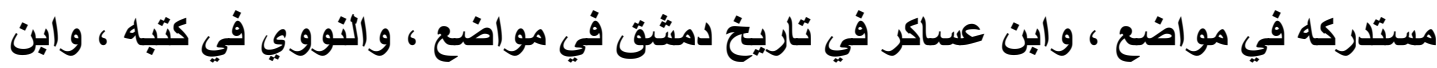

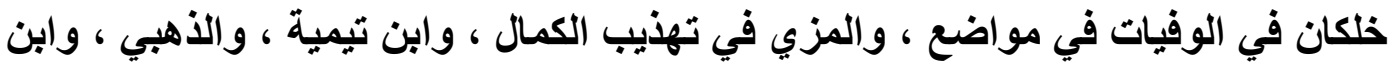

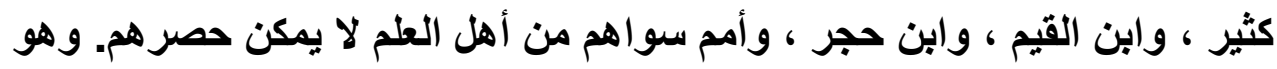

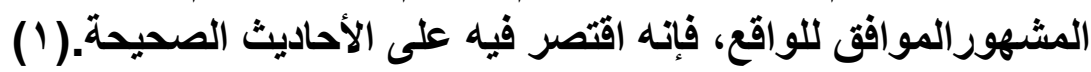

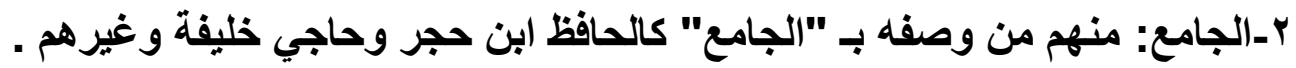
وقال صديق خان : في معرض ذئ ذهره لأنواع كتب الحديث نقلا عن المحدث عبد العزيز الدهلوي

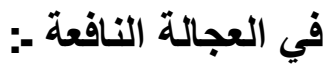

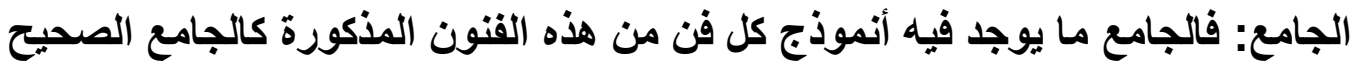

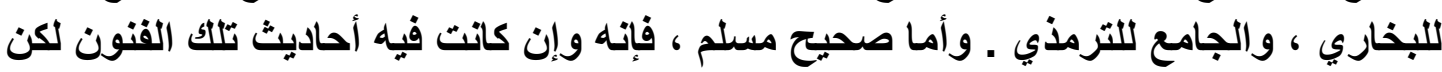

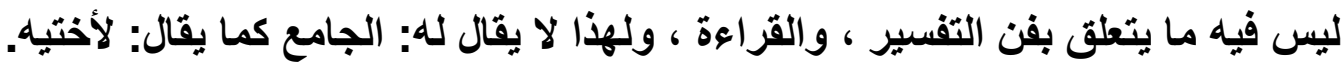

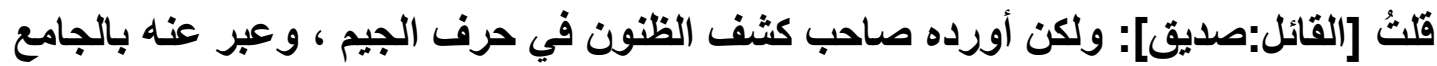

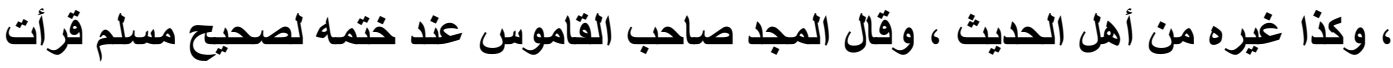

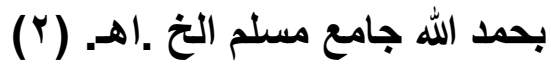

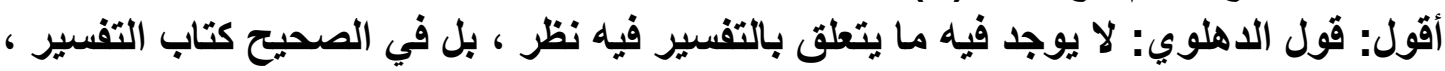

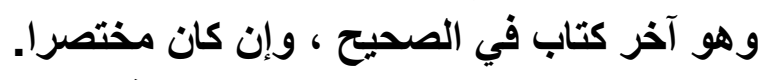

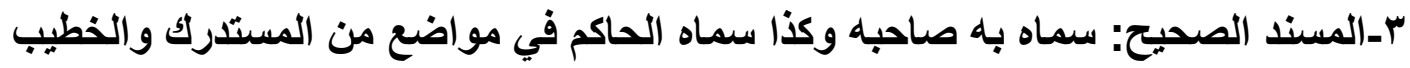

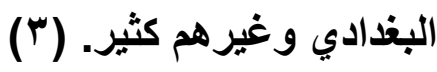

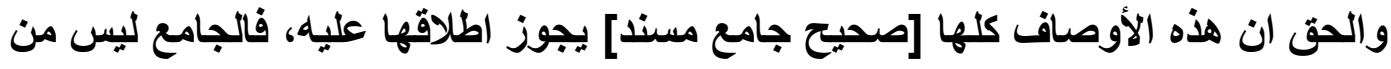

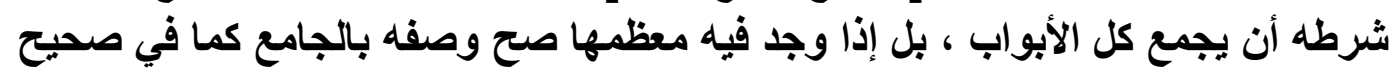

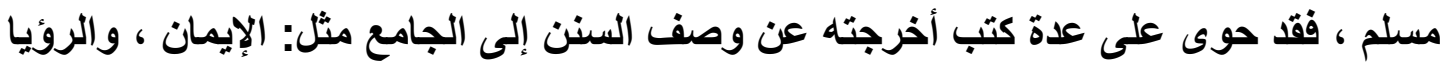

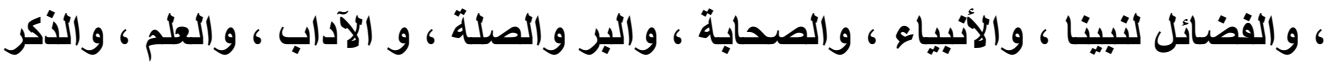

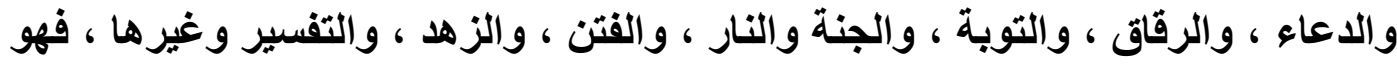

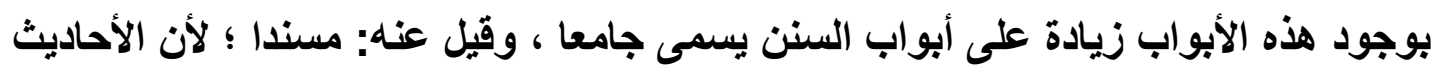
تروى فيه بالإسناد ، وهذا معروف مستعمل.

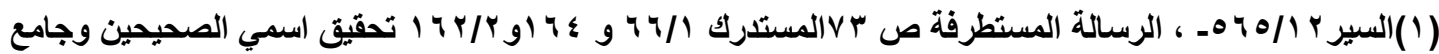

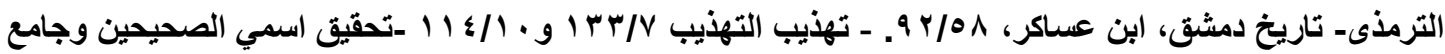

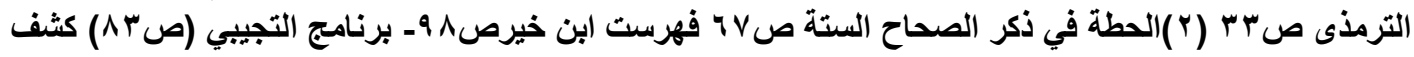

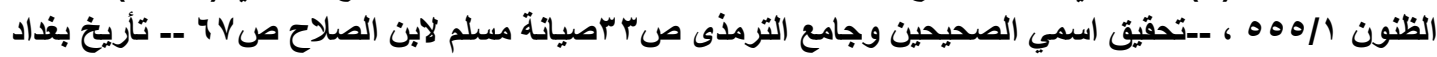

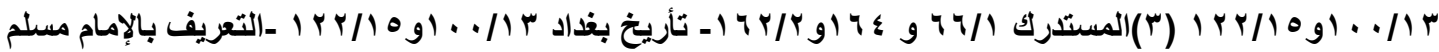
، وكتابه الصحيح : منهجه ، ميزاته ، طبعاته ، شروحه ، وما آنا ألف حوله 


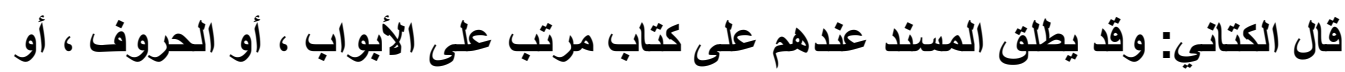

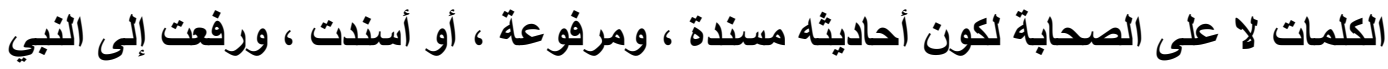

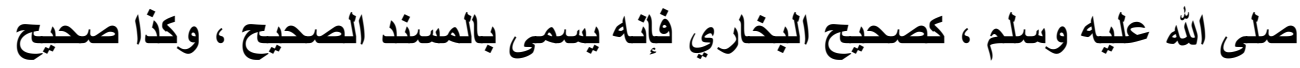

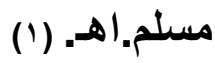

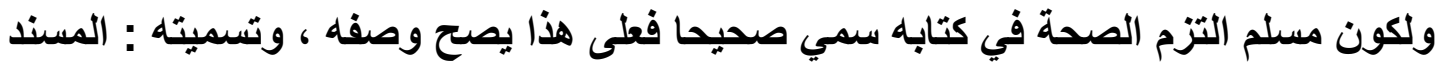

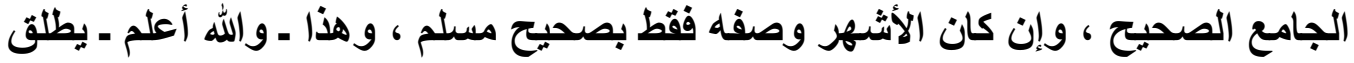

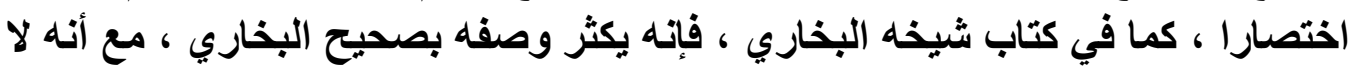

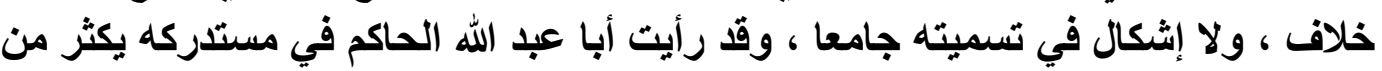

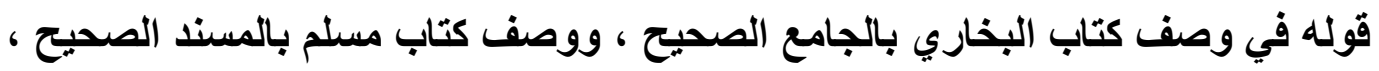
ولعله فعل ذللك موافقة لما جاء عنهما..

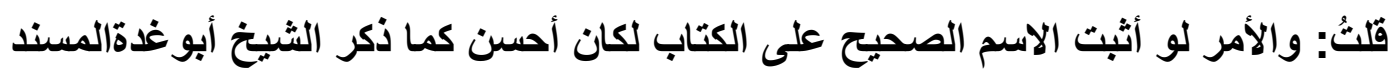

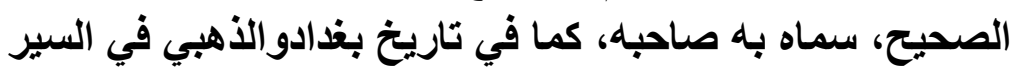

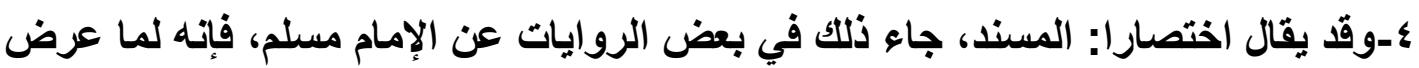

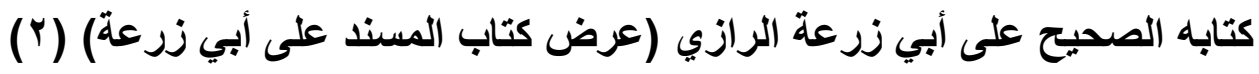
هـالمسند الصحيح المختصر من السنن بنقل العدل عن العدل إلى رسول الله صلي الله عليه

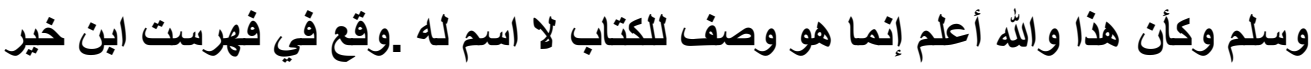

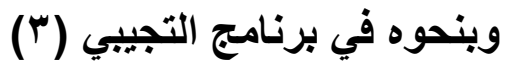
المطلب الثاني سبب تأليفه واهتمامه به و مكان تأليفه

سبب تأليفه: (؟)

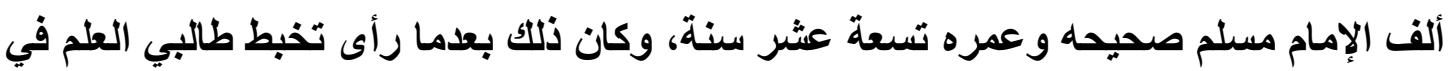

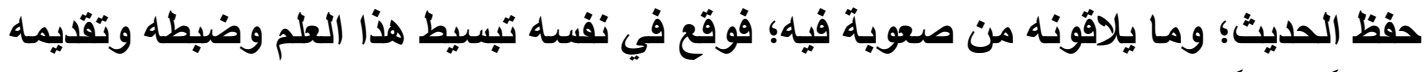

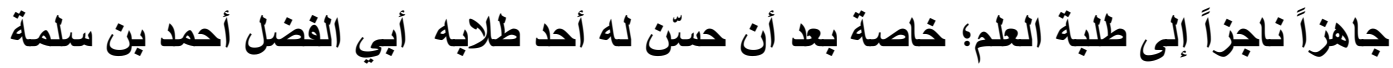

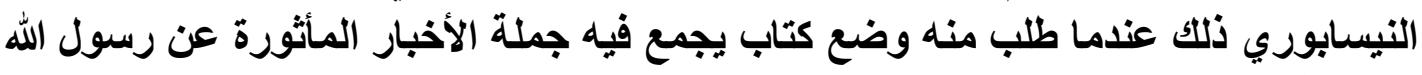

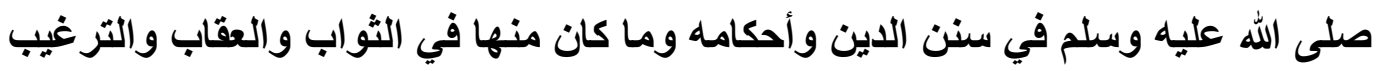

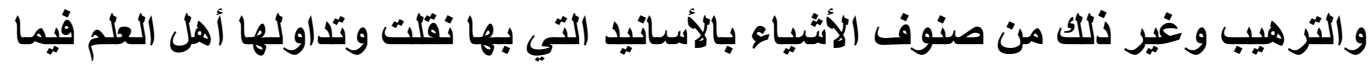

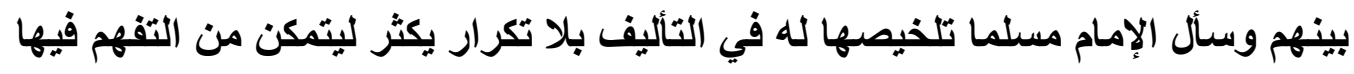

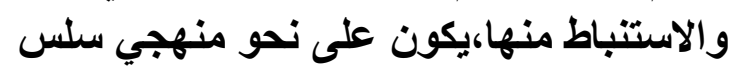
وقد زاده رغبة في الإجابة عليه ما رآه من قيام بعض مض العلماء بجمع الحديث دون تمييز بين صحيح وضعيف ولأهمية هذا المطلوب وما يترتب عليه من منفعة موجودة وعاقبة محمودة له خصوصا

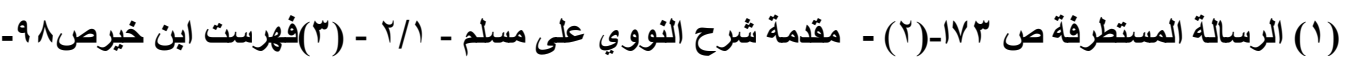

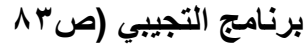

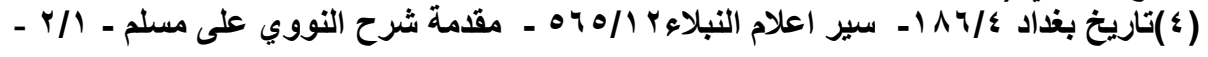


وللمسلمين عموما أقدم على جمع هذه الدرر خالصة نقية من الثوائب وزاده رغبة في القيام

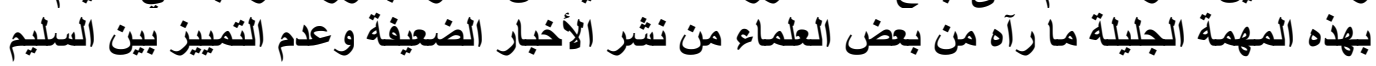

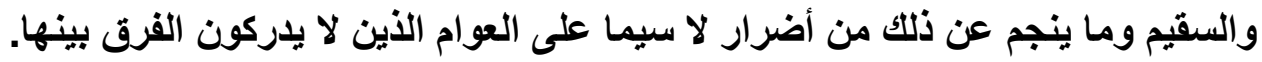
وهذا نص كلامه:

قال الإمام مسلم: فإتك يرحمك الله بتوفيق خالقك ذكرث أنك هممت بالفحص عن تَمَرَّفِ جملة

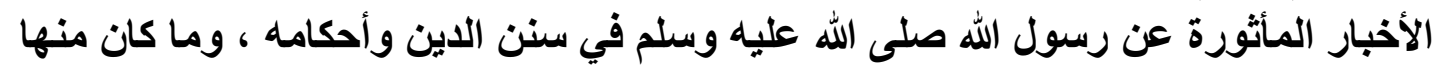

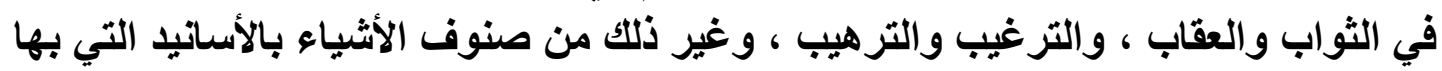

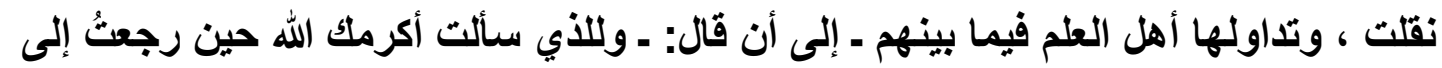

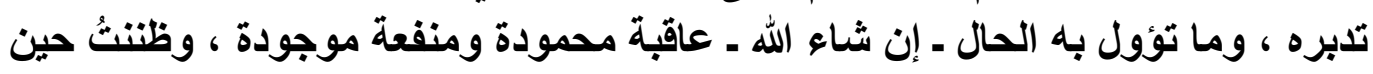

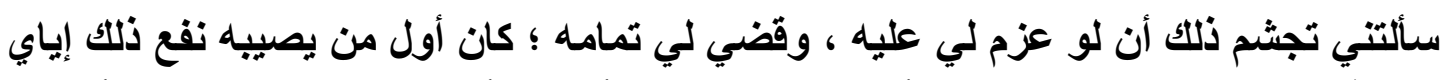

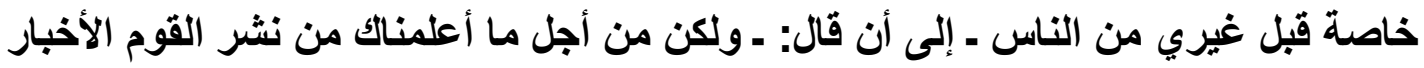

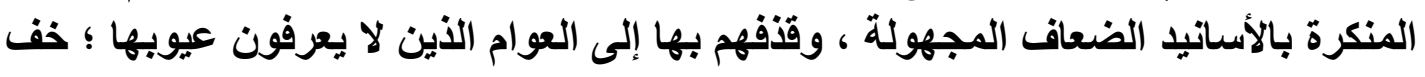

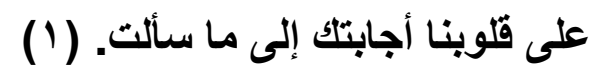
وقد ذكر الخطيب البغدادي : أن مسلما جمع الصحيح لأبي الفضأبل الفي أحمد بن سلمة النيسابوري

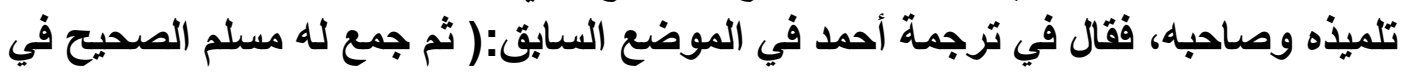

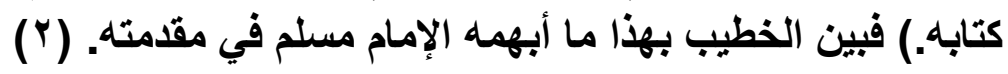

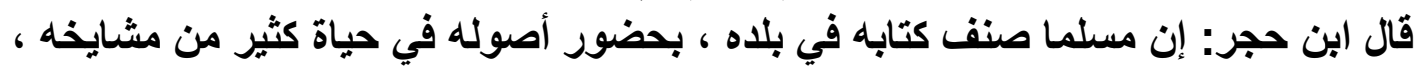

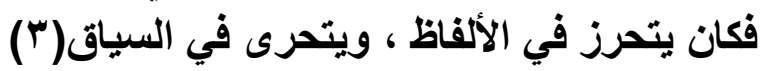

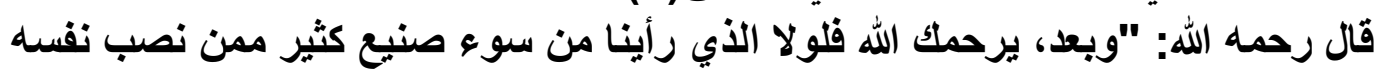

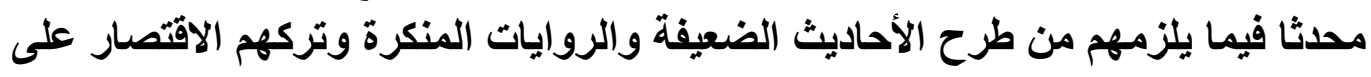

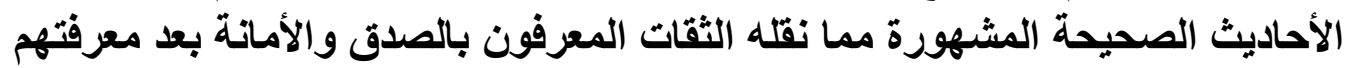

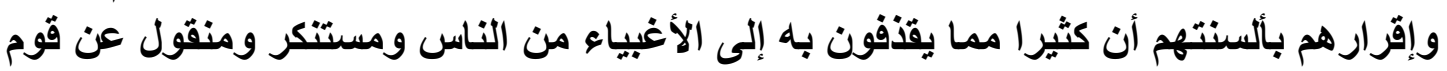

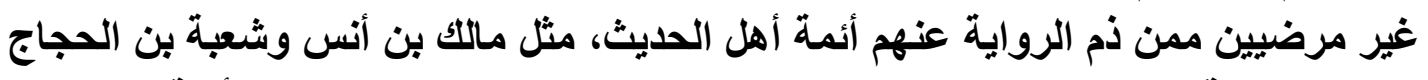
وسفيان عينة ويحي بن سعيد القطان وعبد الرحمن بن مهاي وغيرهم من من الأئمة لما سهل

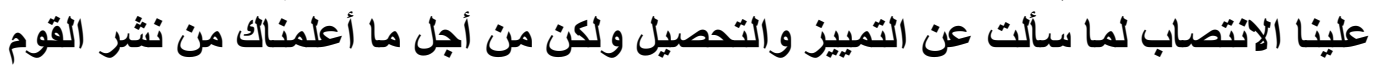

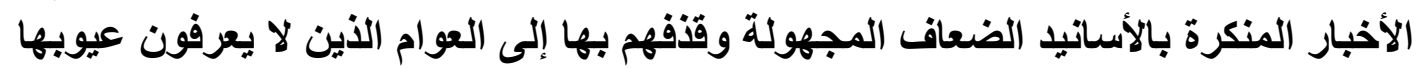

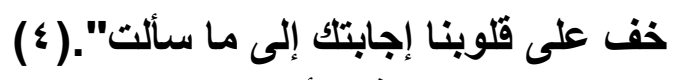
ا اهتمامه و عنايته في تأليفه: قضى الإمام مسلم في تثقيح وتهذيب وانتقاء .. كتابه الصحيح ست عشرة سنة نقل نقل عنه ذلك الإمام النووي في شرحه لصحيح مسلم، كما نقلّه صاحب السراج الوهاج شرح فحس صحيح مسلم بن الحجاج. وهذه المدة المذكورة مدة التهذيب والانتقاء .. أما مدة التبيضيض والتأليف فإنها أكثر من ذلك.

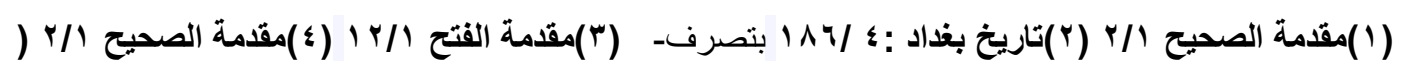

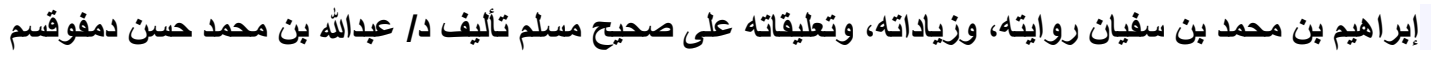

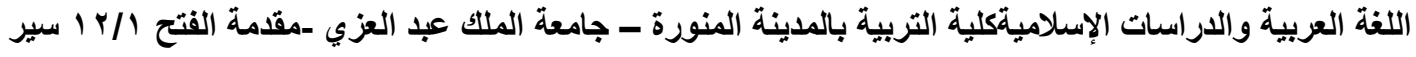

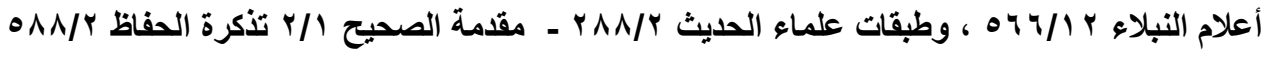


قال الإمام النووي :وقد انتخب علمه ولخص ما ارتضاه في هذا الكتاب، ويقي في تهذيبه وانتقائه

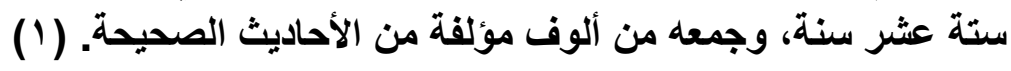

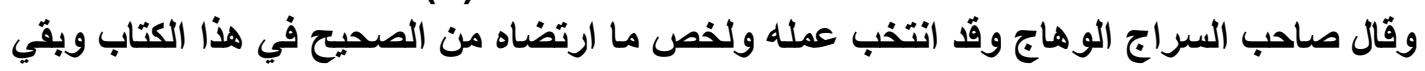

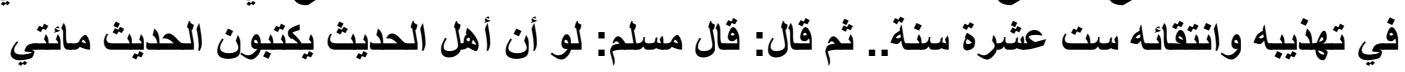

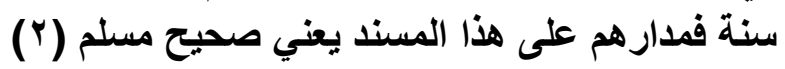

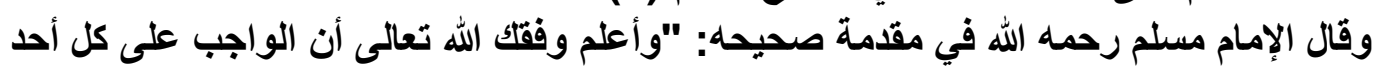

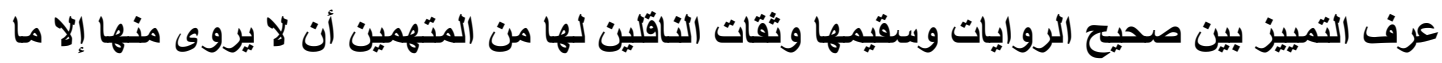

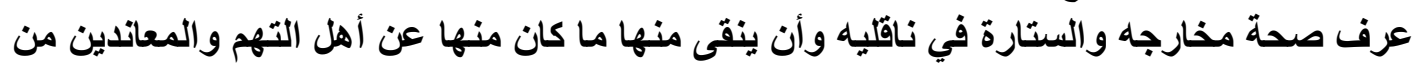

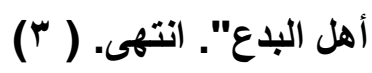

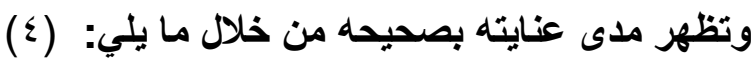

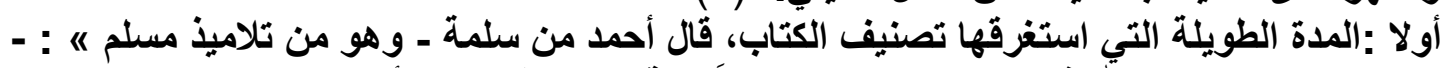

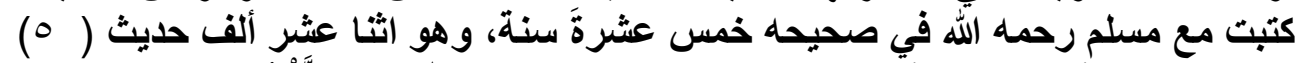

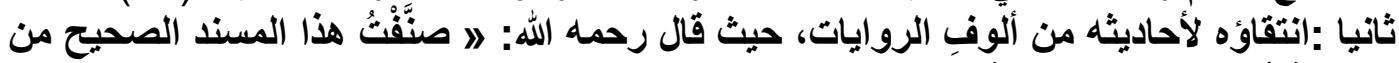

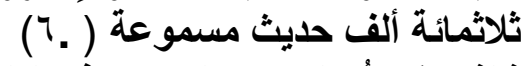

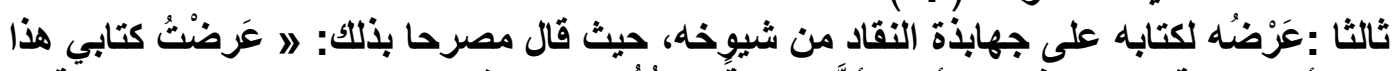

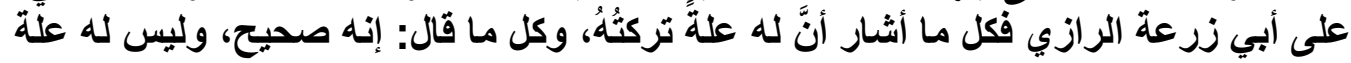

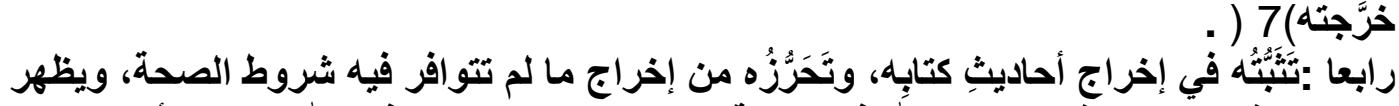

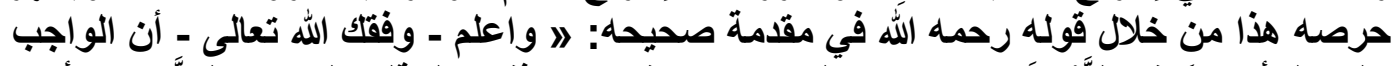

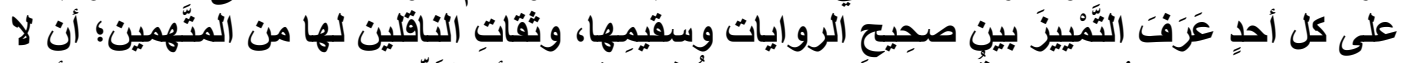

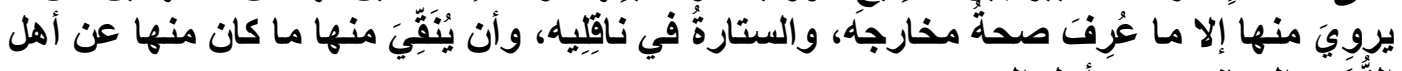

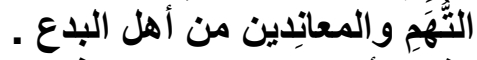

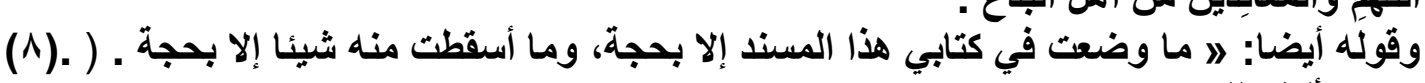

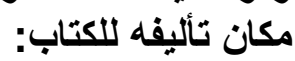

إن مسلما صنف كتابه في بلده ، بحضور أصوله في حياة كثير من مشايخه ، فكان يتحرز في الألفاظ

$$
\text { ، ويتحرى في السياق(9) }
$$

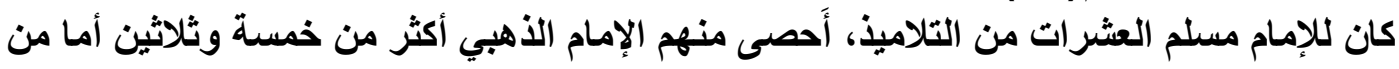

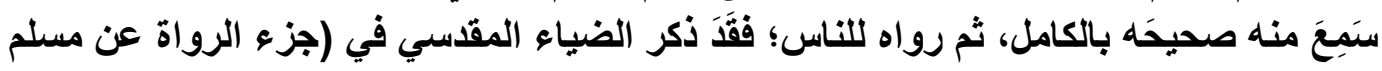

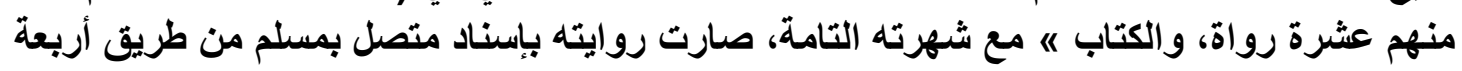

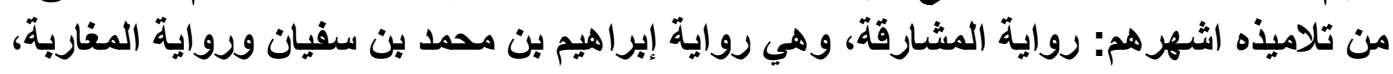
وهي رواية القلانسي.

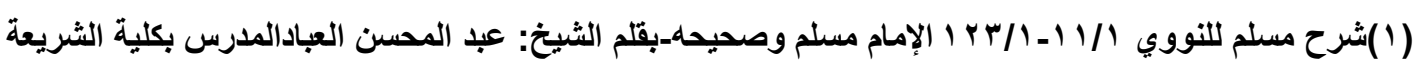

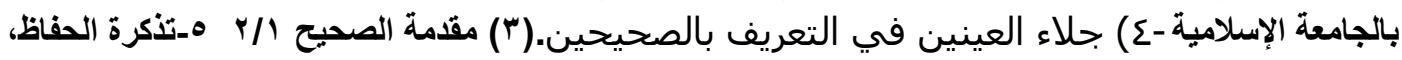

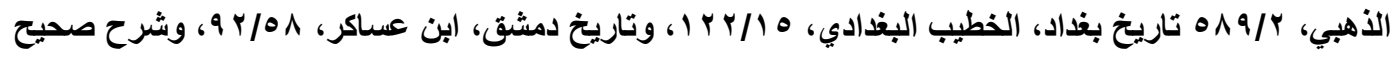

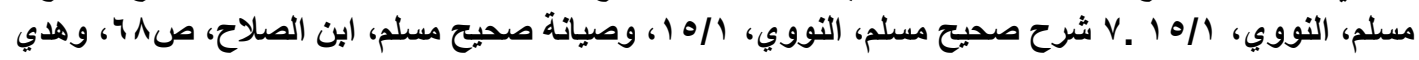

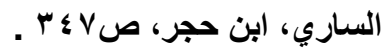

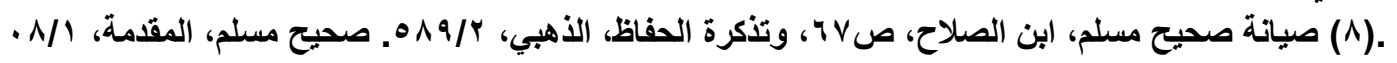

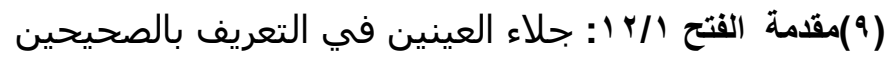

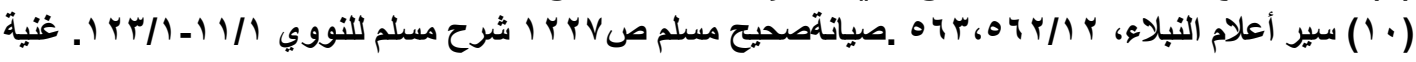

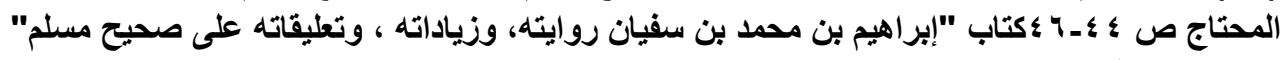

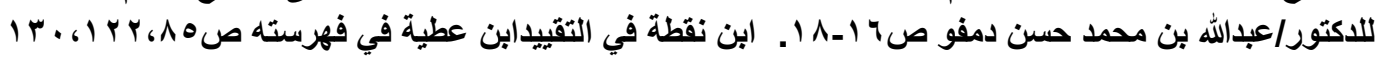


قال الإمام النووي: (1). لا صحيح مسلم رحمه الله في نهايةٍ من الثهرة، وهو متواترّ عنه

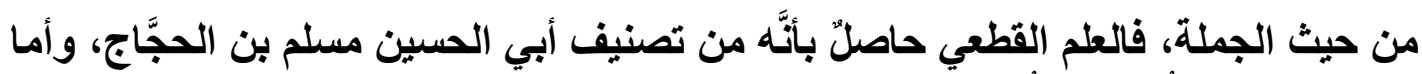

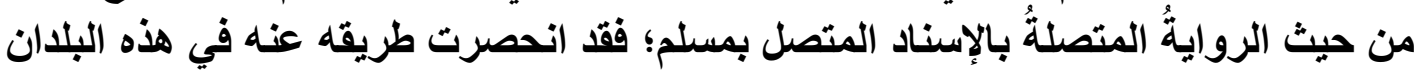

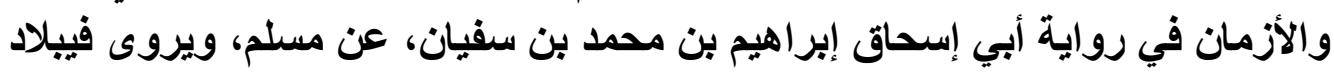

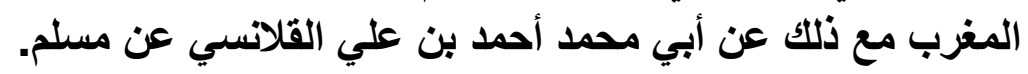

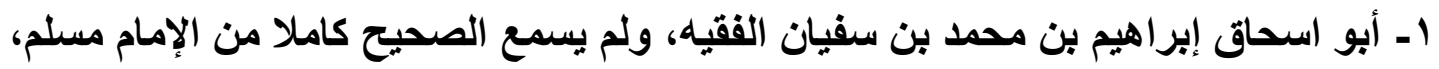

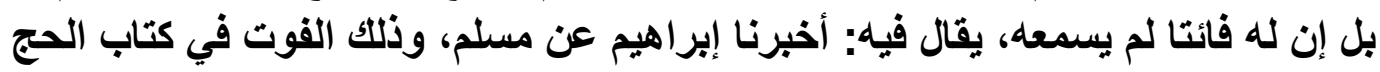

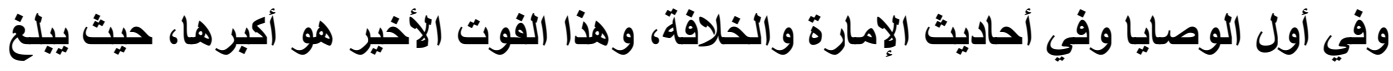

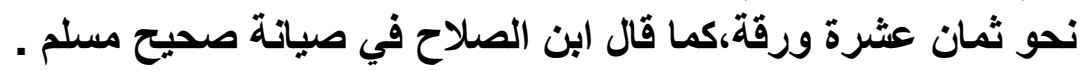

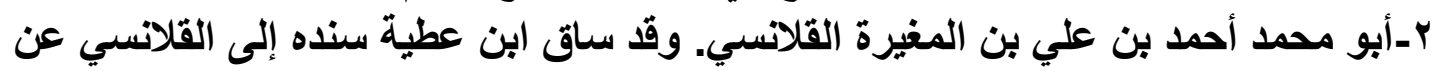

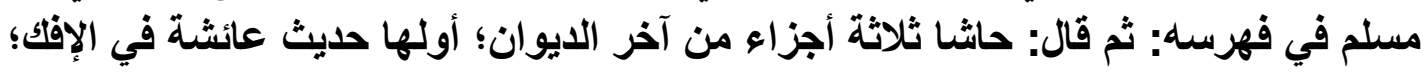

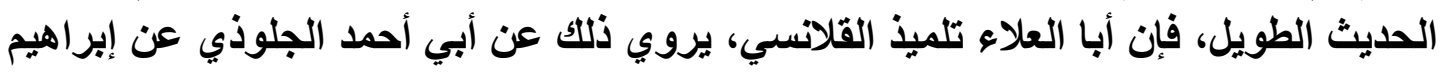

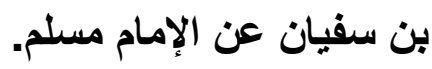

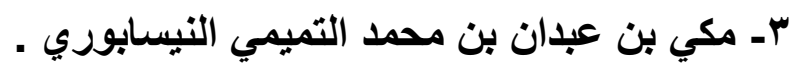

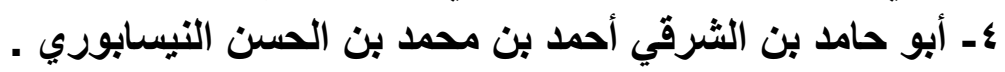

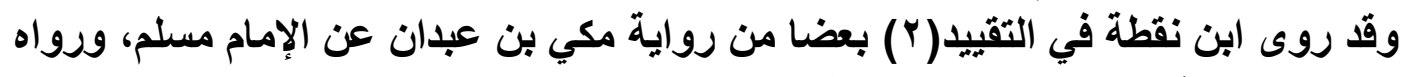

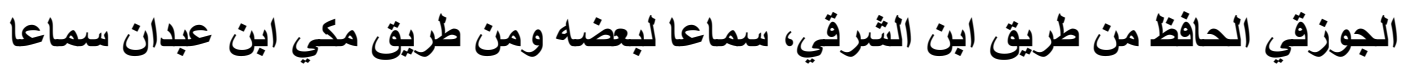

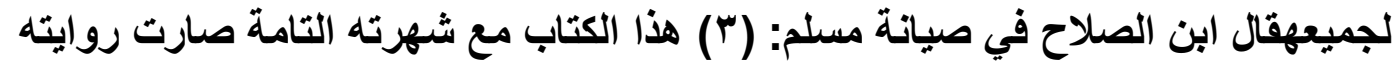

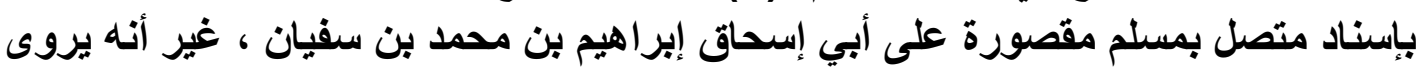

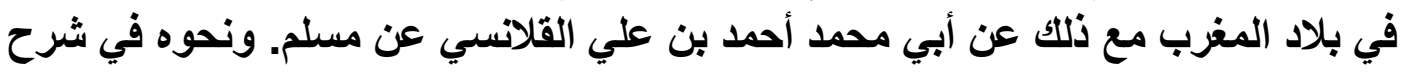

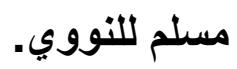

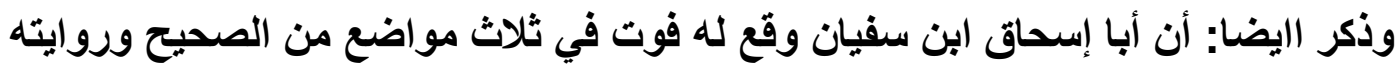

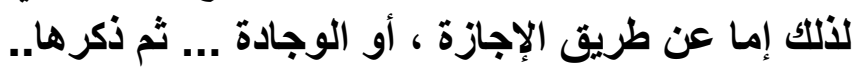

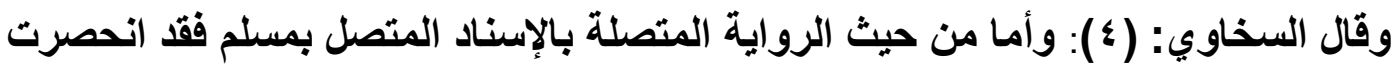

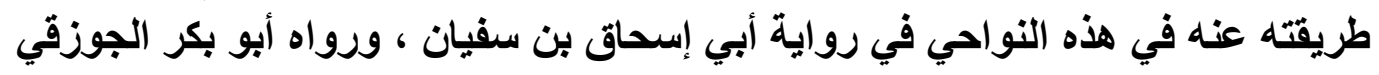

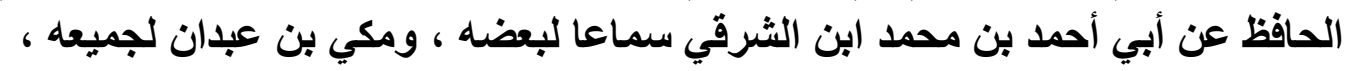

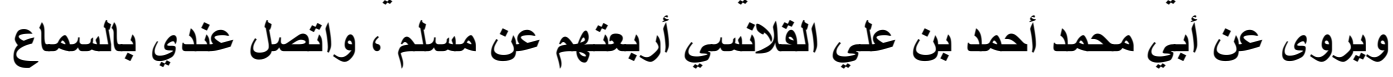

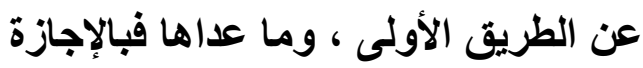

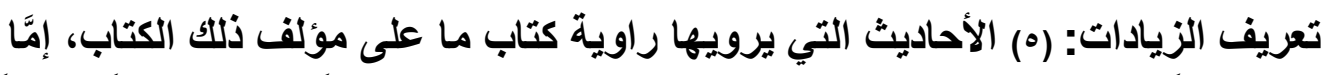

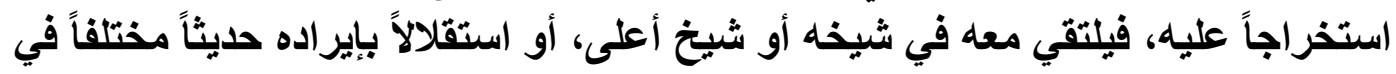

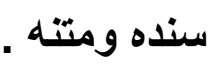

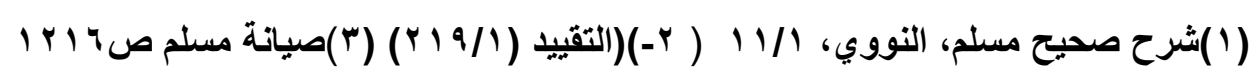

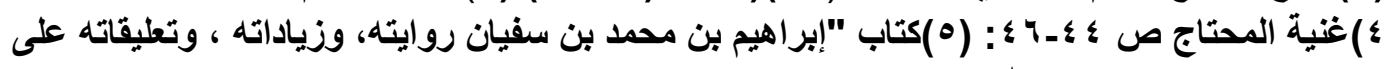

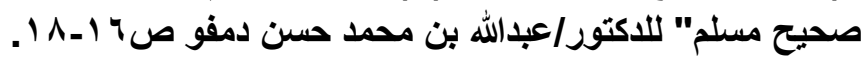


والفرق الزيادات وبين المستخرجات:(1)

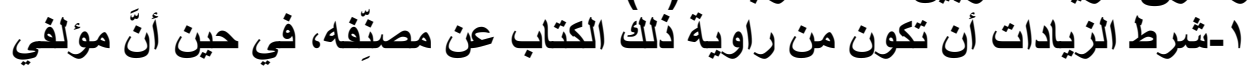

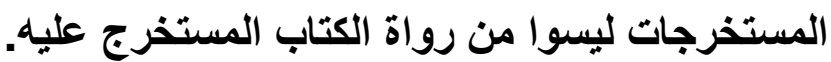

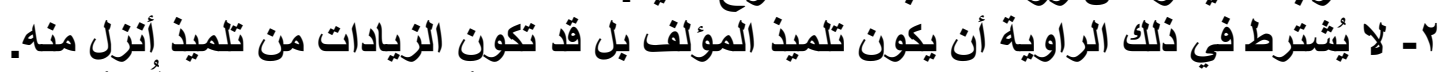

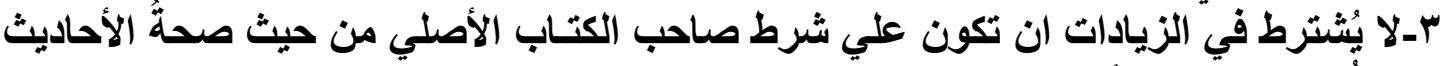

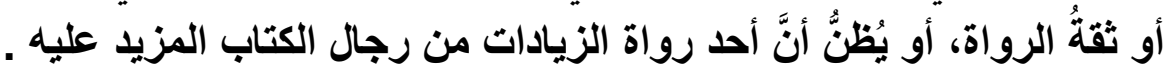

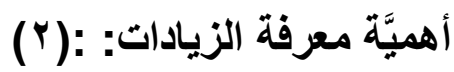

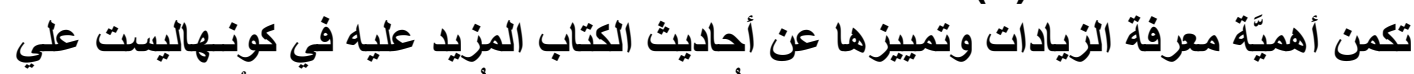

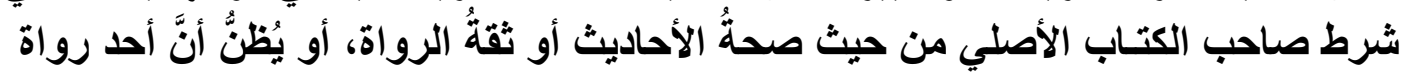
الزيادات من رجال الكتاب المزيد عليه .

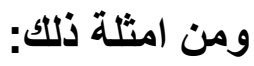

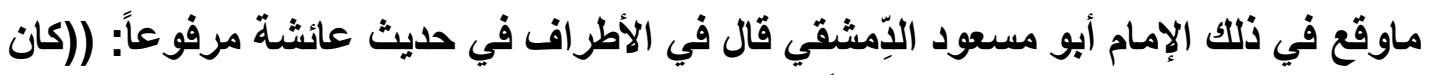

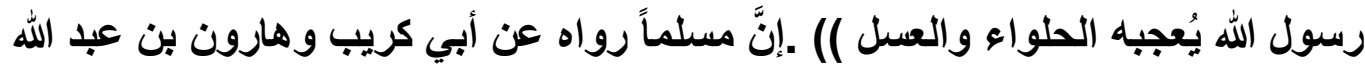

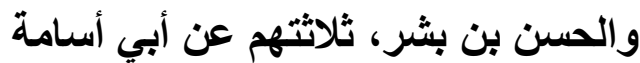

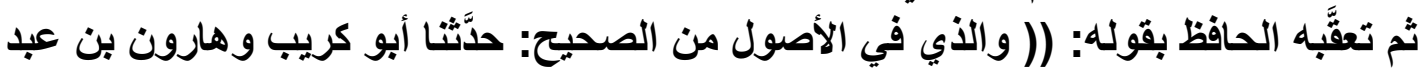

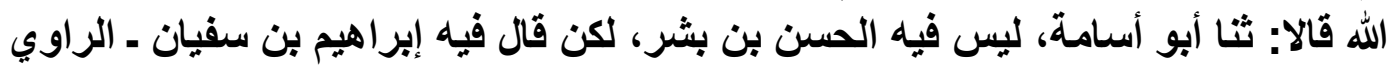

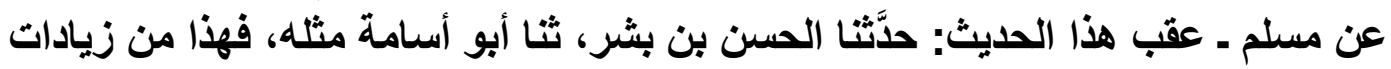

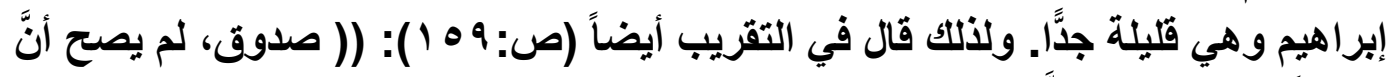

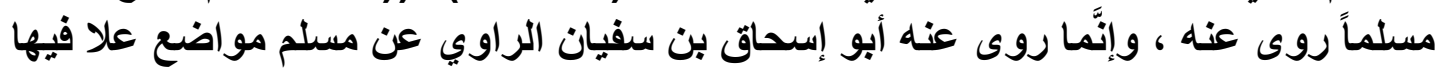

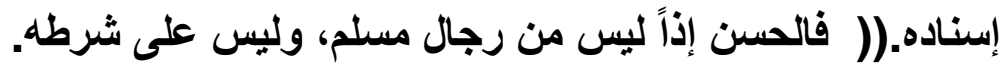

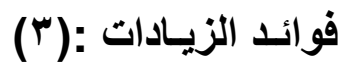

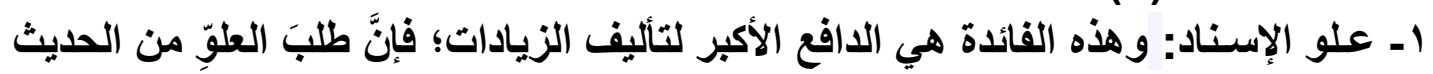

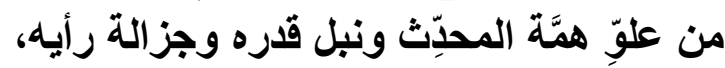

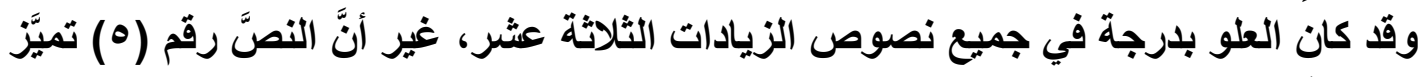

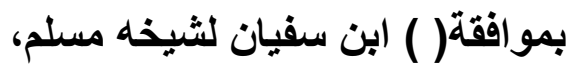

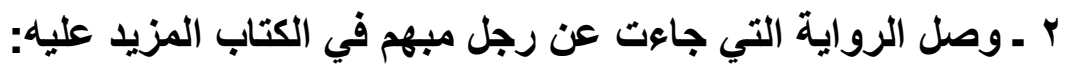

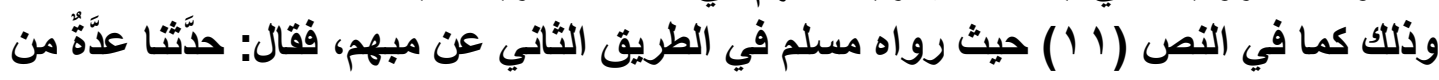

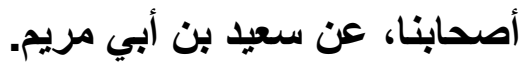

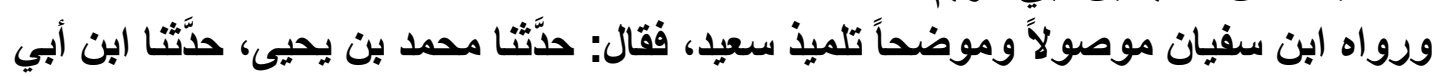
مريم. ومحمد بن يحيى هو الذهان هوصولاني.

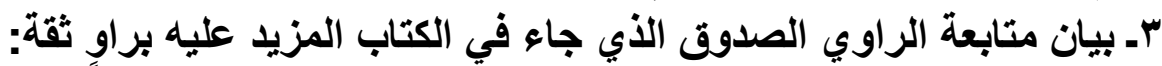

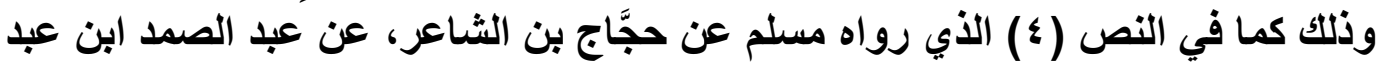

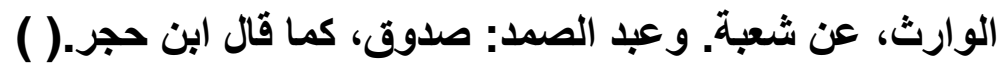

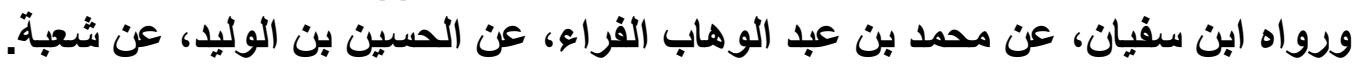

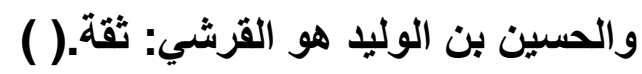

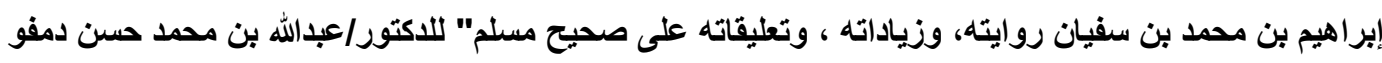

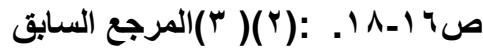


ــ ـ تكثير طرق الحديث، و دفع الغرابة:

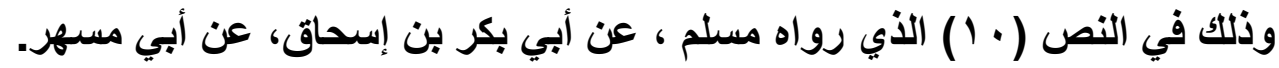

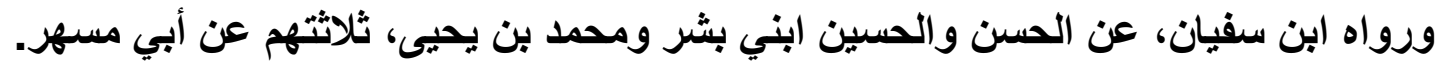

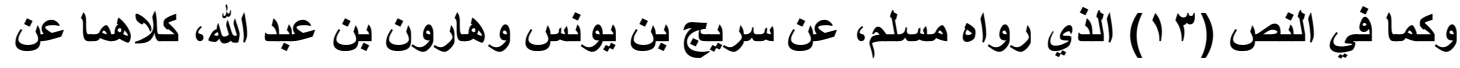

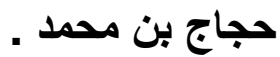
ورواه ابن سفيان، عن الحسين بن عيسى البسطامي وسهل بن عمار و إبراهيم بن بنت حفص

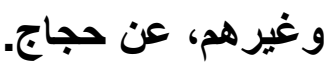

هـ دفع احتمال اختصار متن الحديث من أحل الرواة في إسناد الكتاب المزيد عليه، وتحميله

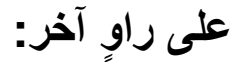

وذلك كما في النص ( • () الذي رواه مسلم من طريقي مروان الامشقي وأبي مسهر ، كلاهما

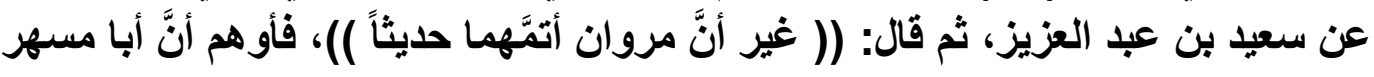

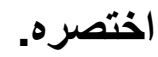

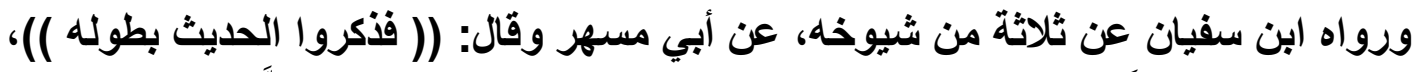

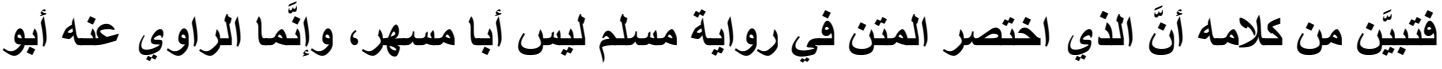

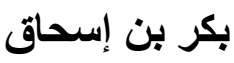

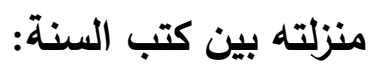

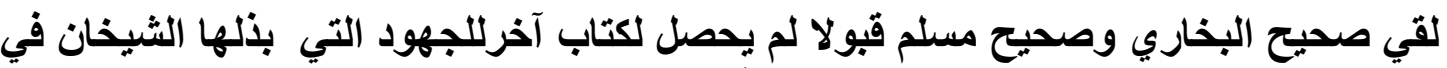

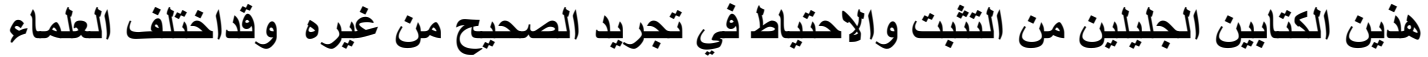

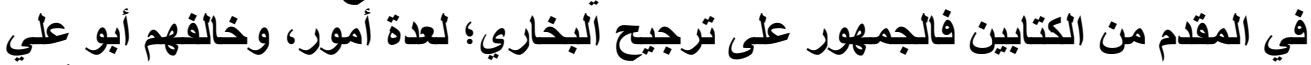

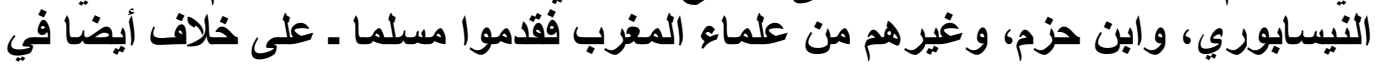

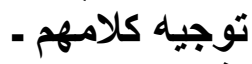
فالجمهور على ان صحيح مسلم يأتي في الارجة الثانية بعد صحيح البخاري فهو ثاني كتابين هما أصح الكتب بعد كتاب الله تعالى. فيدي

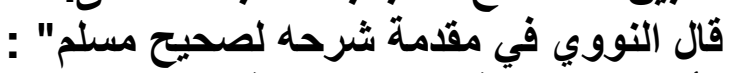
وأصح مصنف في الحديث بل في العلم مطلقا الصحيحان للإمامين القدوتين أبي عبد الله محمد

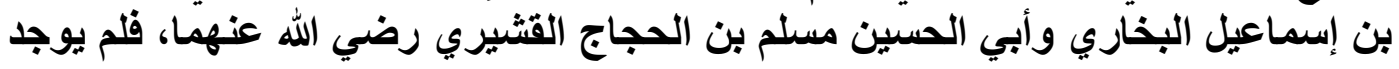

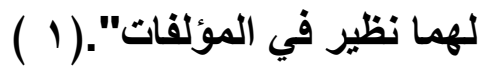

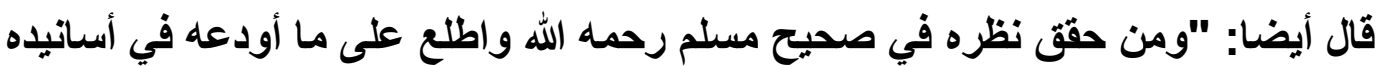

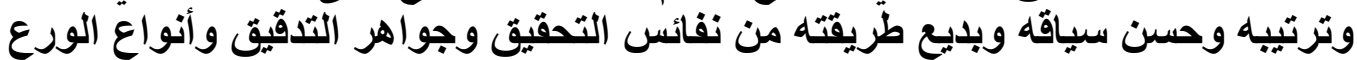

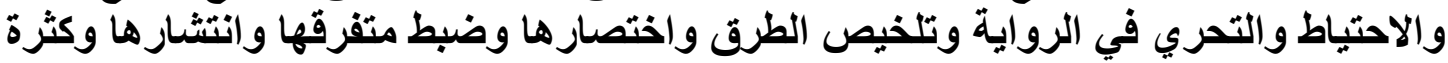

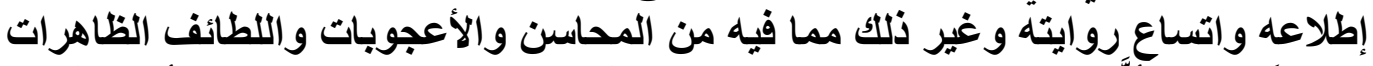

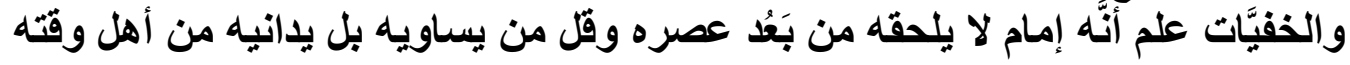

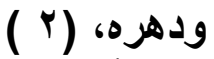

وقال أيضا: "اتفق العلماء رحمهم الله على أن أصح الكتب بعد القرآن العزيز الصحيحان

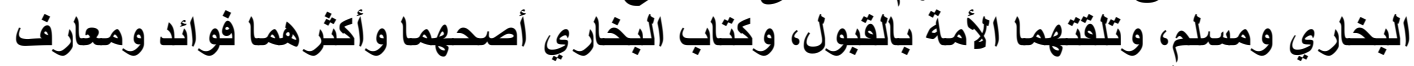

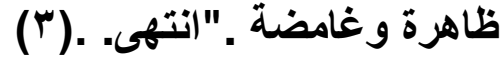

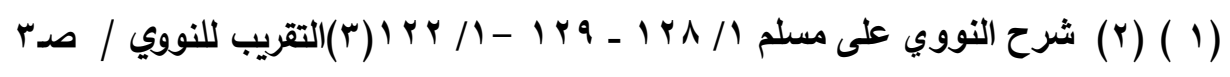




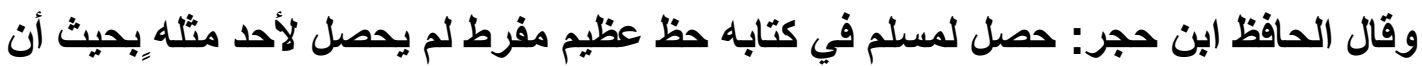

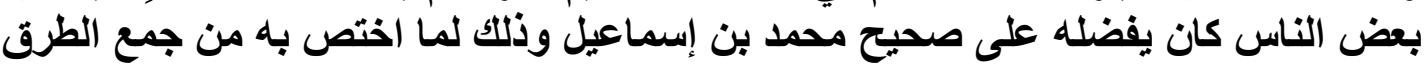

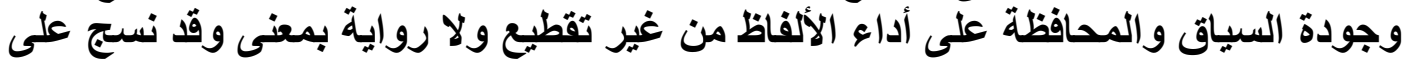

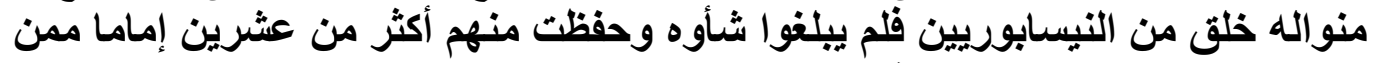

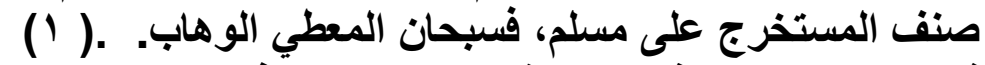

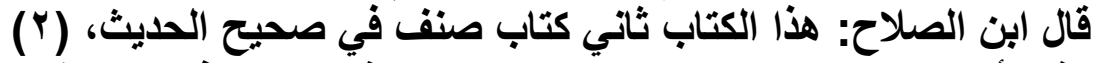

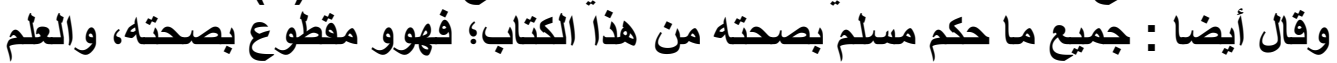
النظري حاصل بصحته في نفس الأمر، ... وذلك لأن الأمة تلقت ذللك بالقبول سوى من من لا يعتد

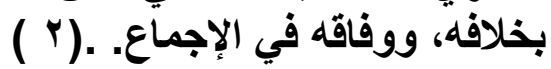
امامانقل عن أبي علي النيسابوري شيخ الاجعاع (الحاكم قوله: "ما تحت أديم السماء كتاب أصح من

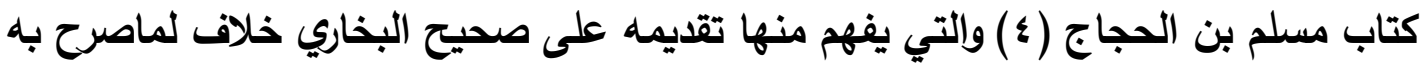
جمهورالعلماء من ترجيح صحيح البخاري عليه

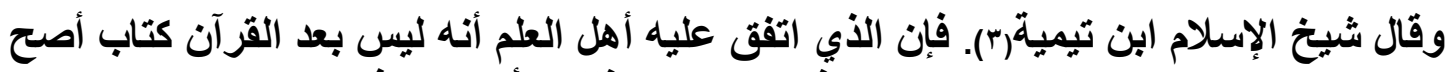

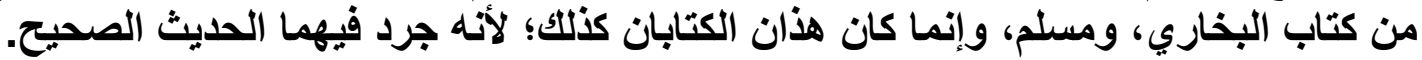

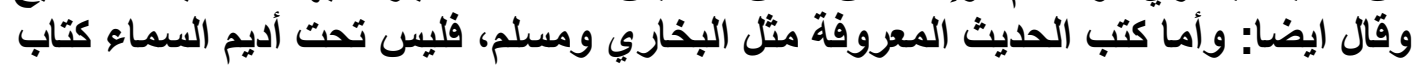

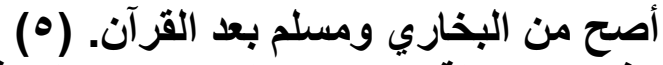
هذه هي منزلة صحيح مسلم بين كتب السنة فهو في في أعلى درجات الصحيح لا يتقدمه في ذلك

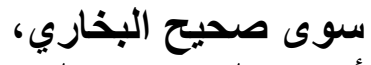

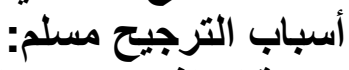
اولا:قال الذهبي ردا علي عبارة أبي علي النيسابوري"قلت :لعل العل أبا علي ما وصل إليه صحيح

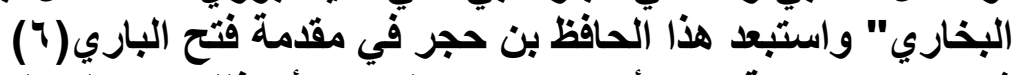

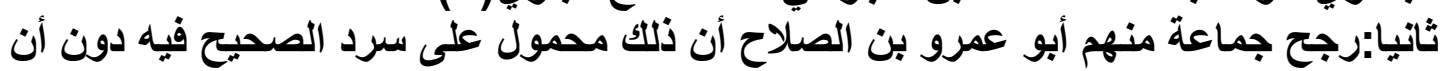

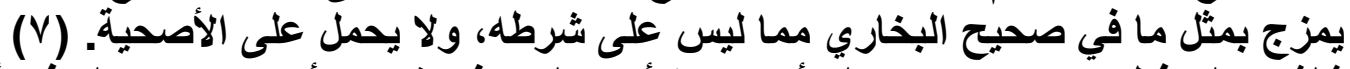

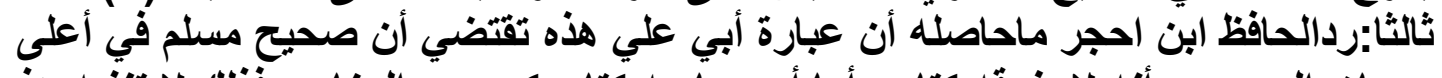

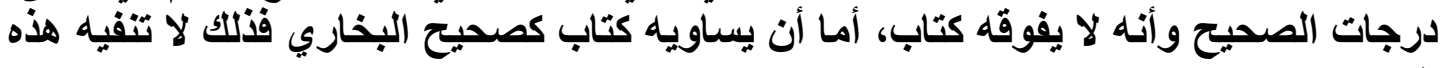

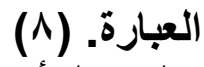

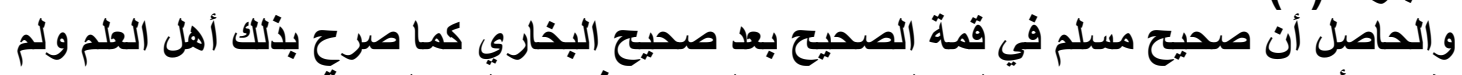
يفصح أحل بترجيح صحيح مسلم على صحيح البخاري فيما يتعلق بالصحة. 
المطلب الثالث خصائص صحيح مسلم

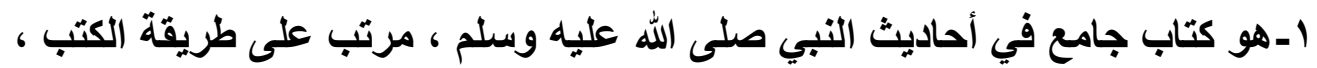

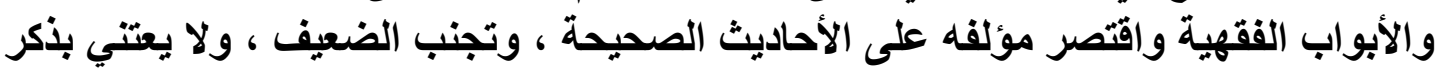

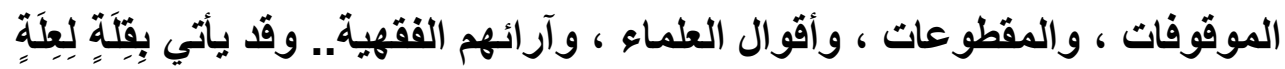

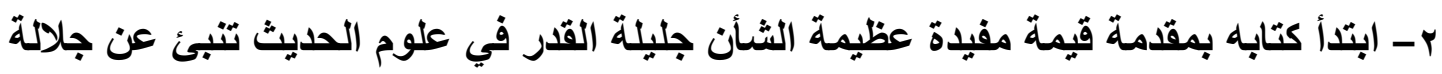

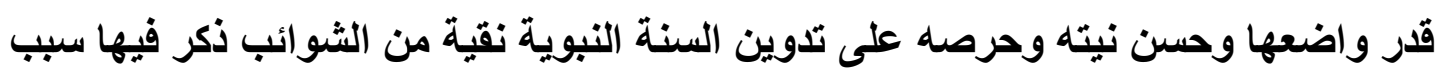

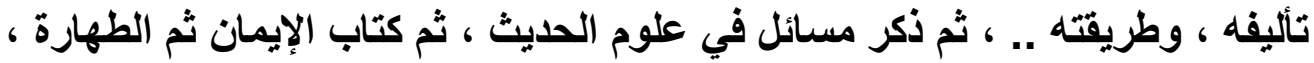

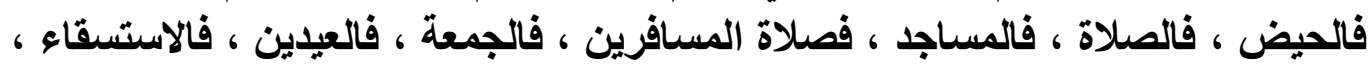

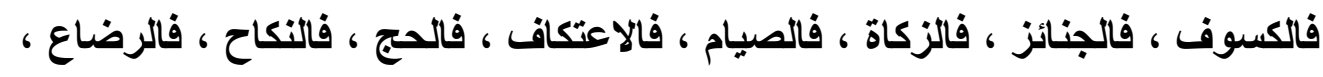

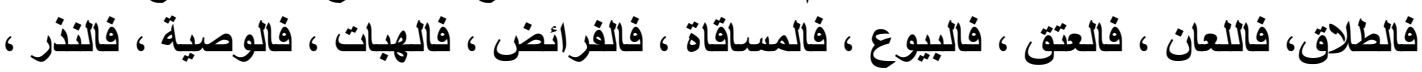

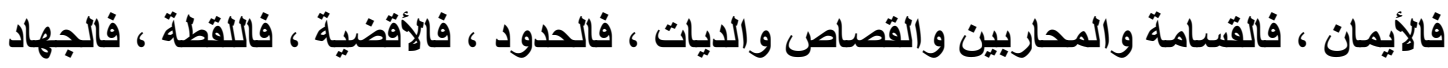

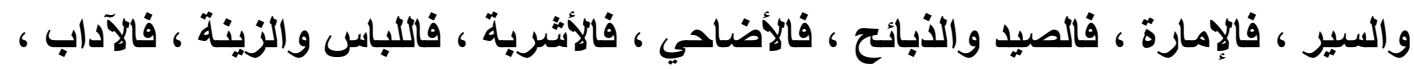

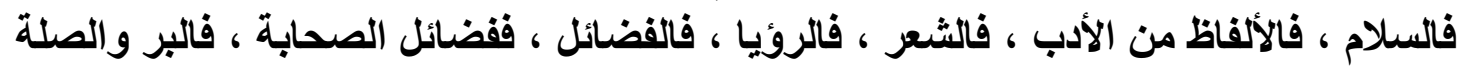

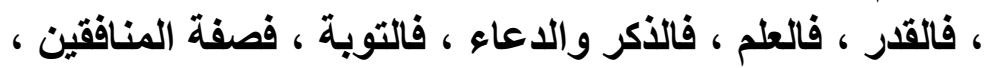

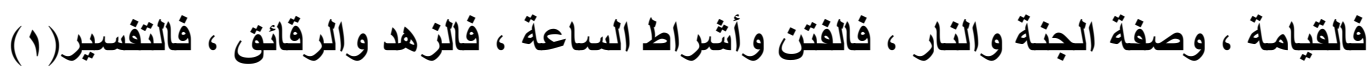

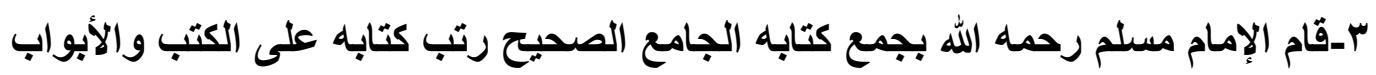

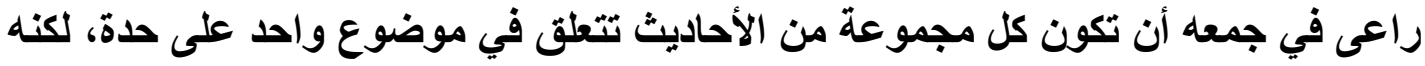

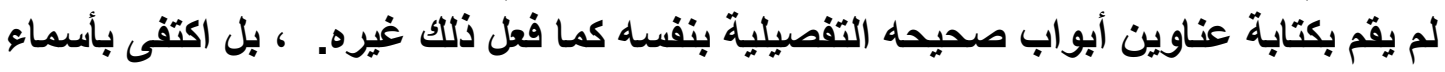

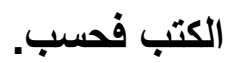
وهو في الحقيقة في حكم المبوَّب وإنما فعل ذلك مسلم والله أعلم لئلا يزيد بها حجم الكتاب من

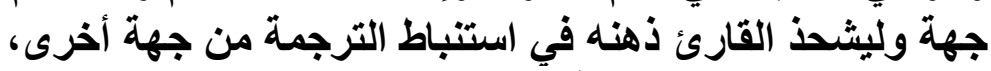

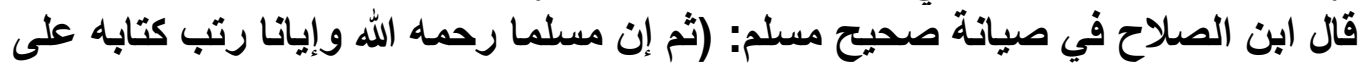

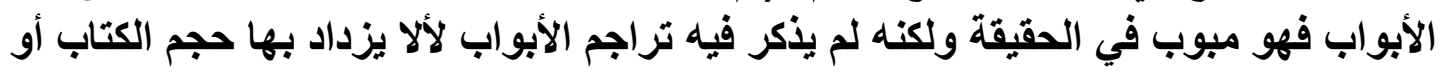

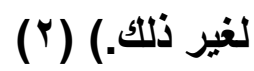

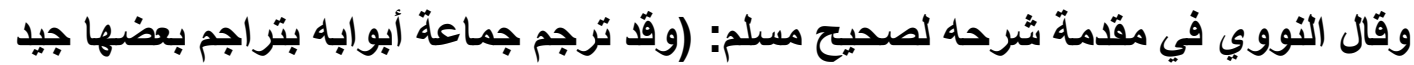

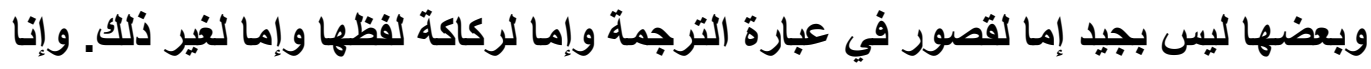

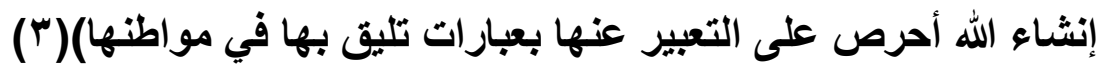

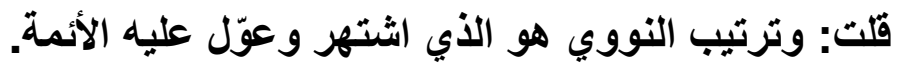

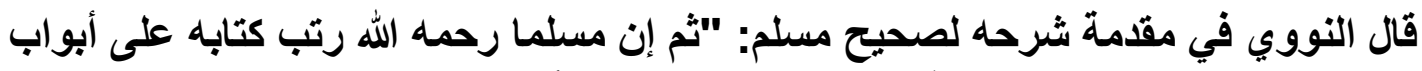

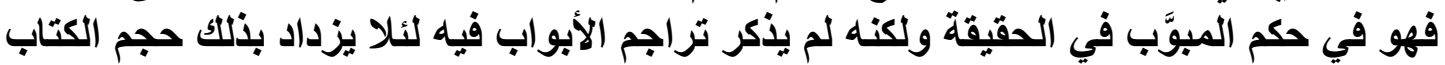

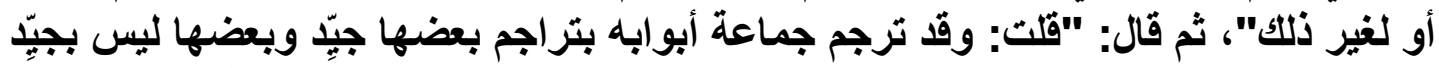

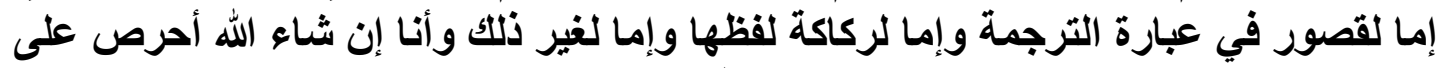

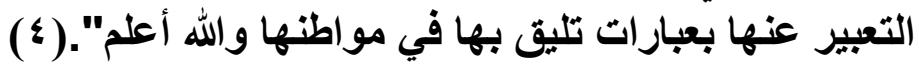

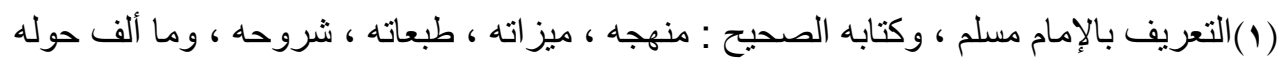

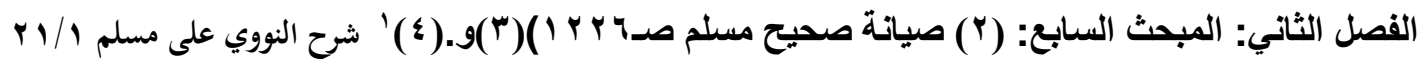


في كثير من التراجم السمة الغالبة عليها الطول لعل السبب في ذلك رغبته في ان تكون

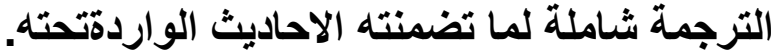

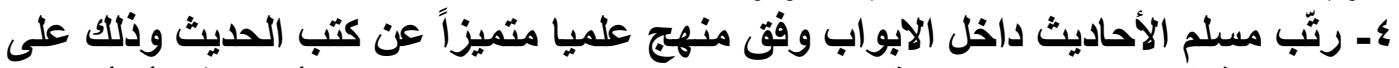

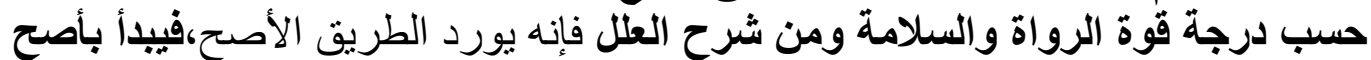

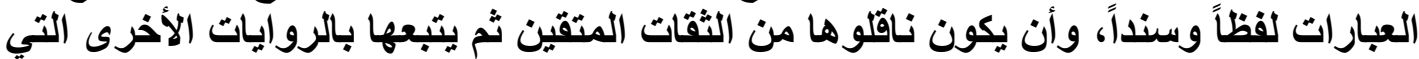

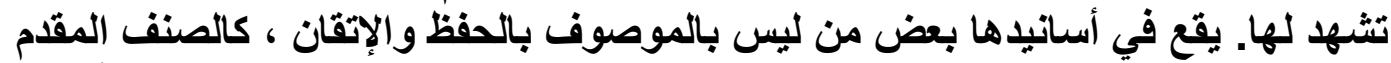

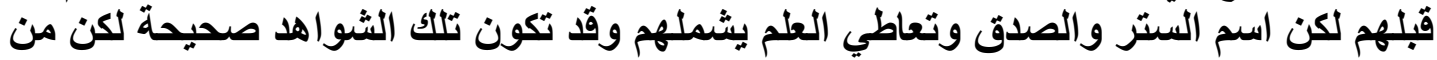

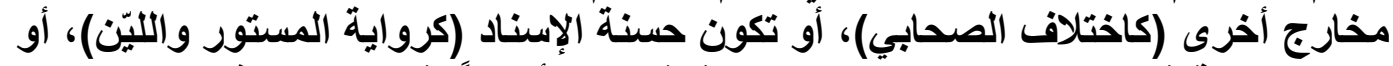

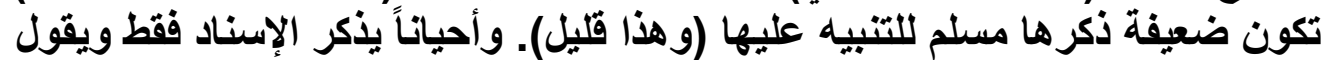

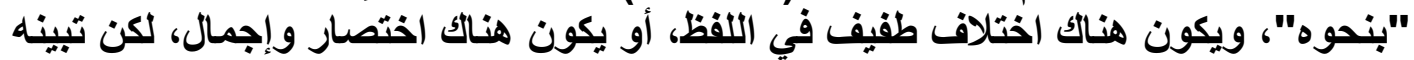

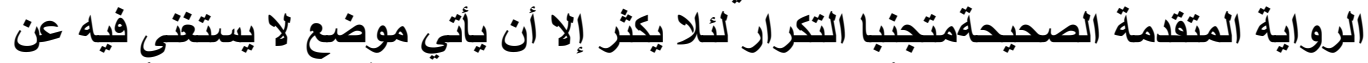

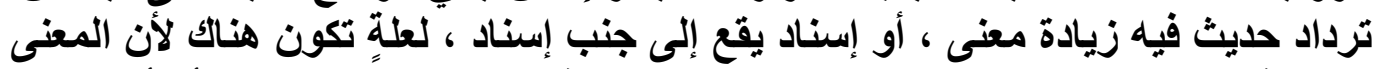

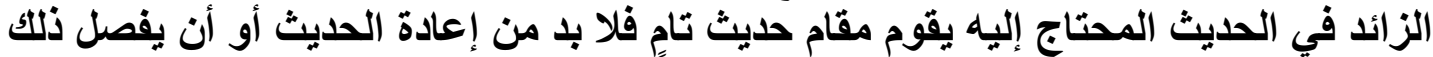

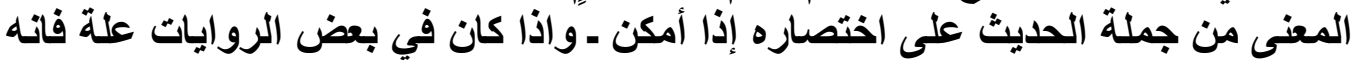

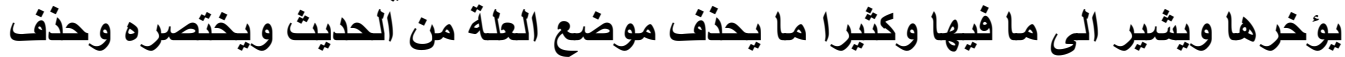

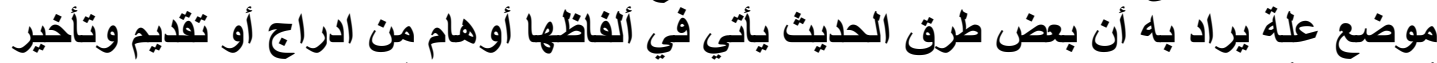

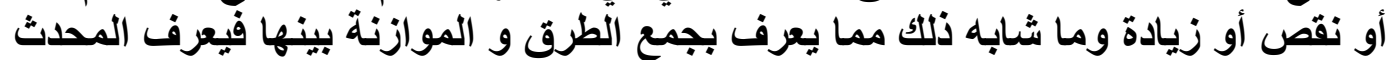

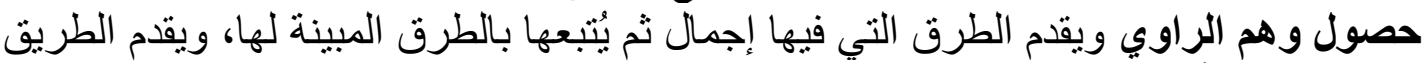

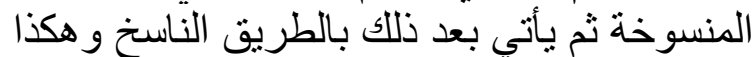

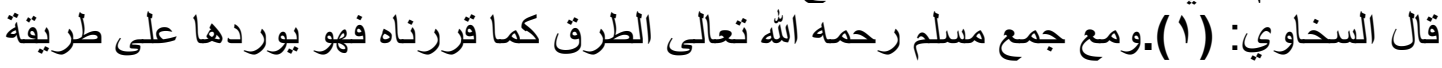

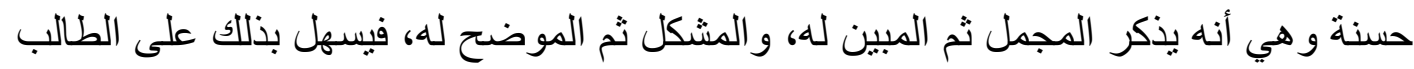

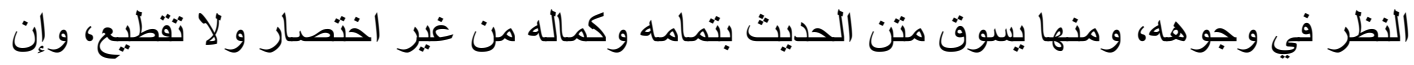

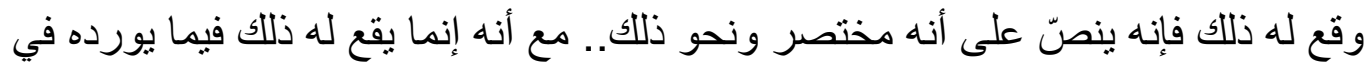

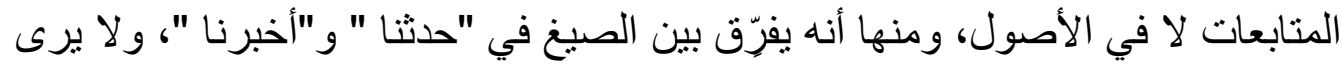

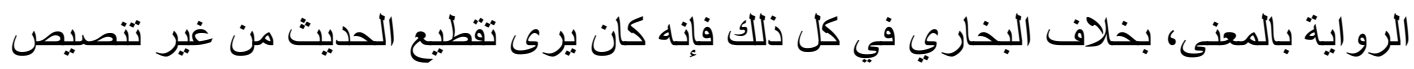

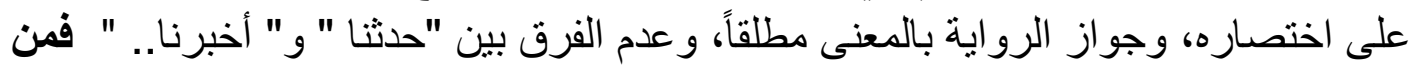

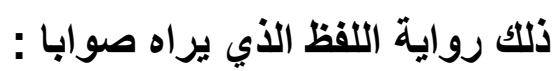

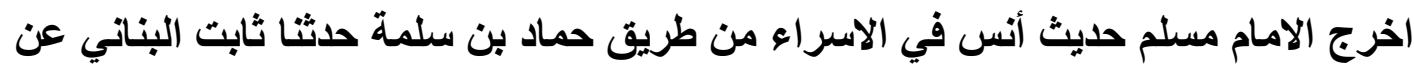

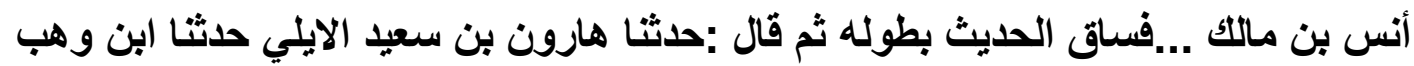

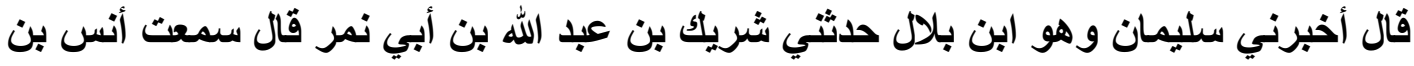

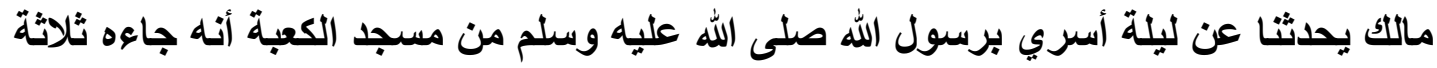

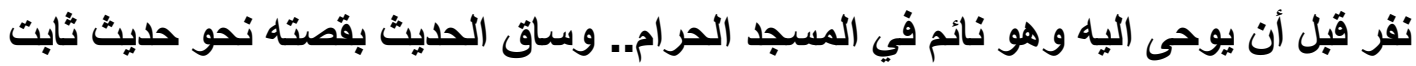

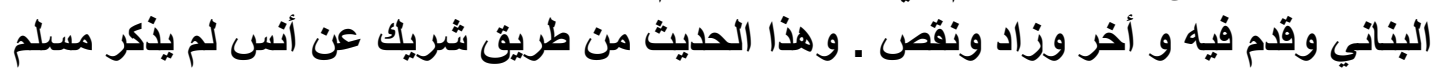

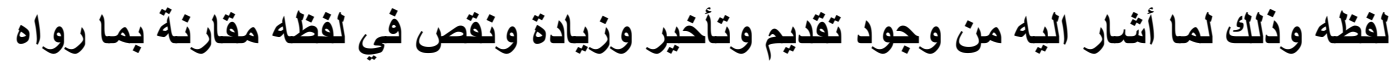


الثقات الأخرون ،وكاتت هذه علة اقتضت من مسلم رواية اللفظ الذي يراه صوابا وقدمه ومثال آخر حذف موضع العلة عمدا: حديث أبي اسحاق عن آلافي الاسود عن عائشة ،قالت [كان رسول الله عليه الصلاة وأزكى التسليم

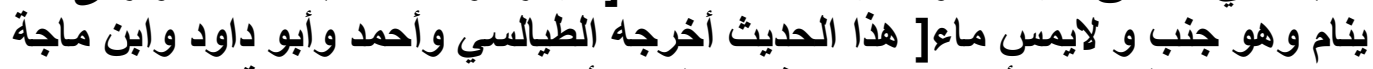

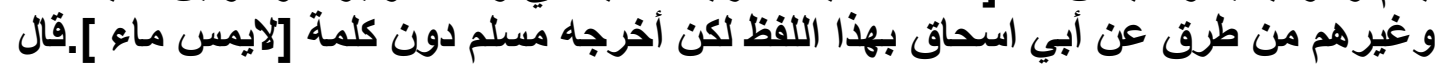

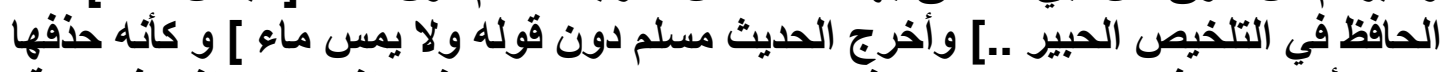

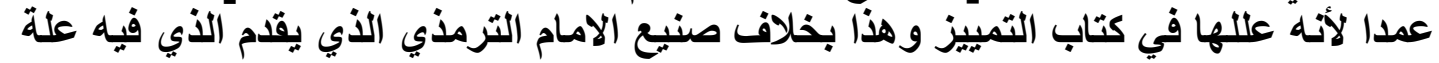

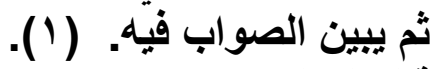

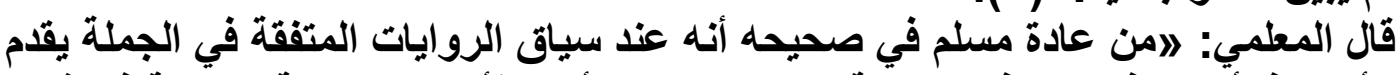

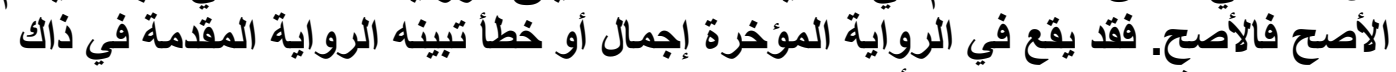

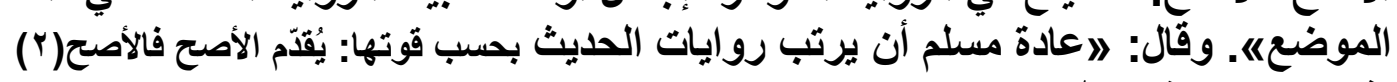

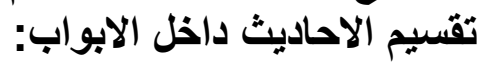

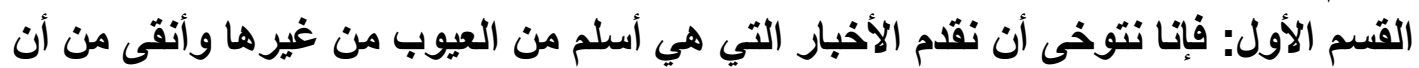

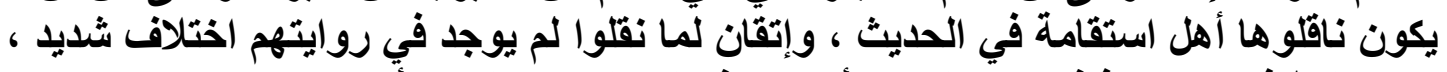

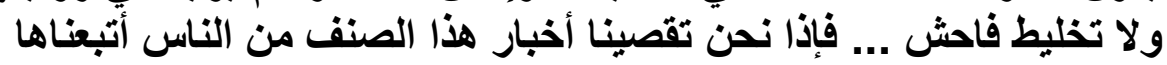

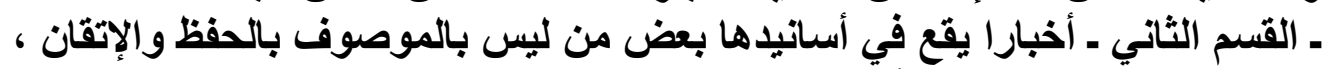

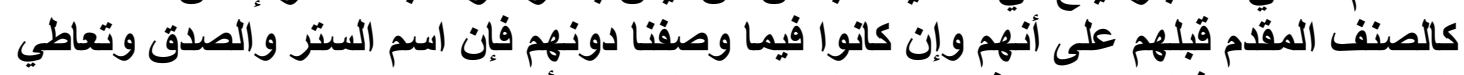

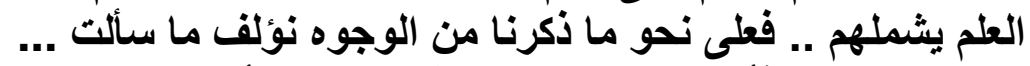

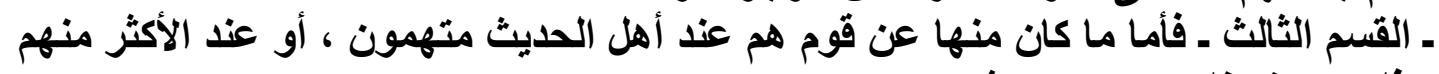

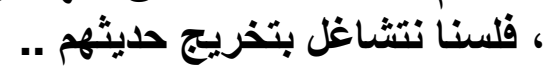

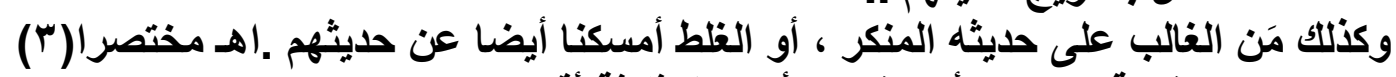

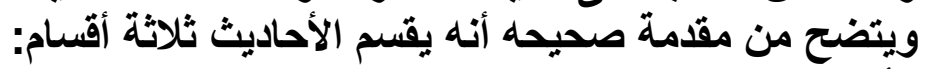

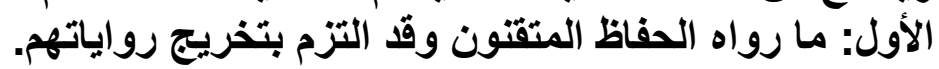

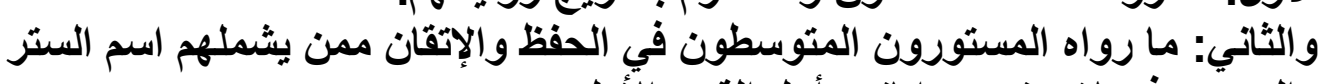

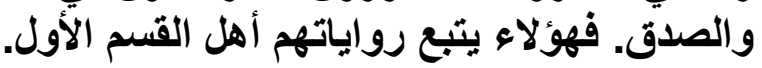

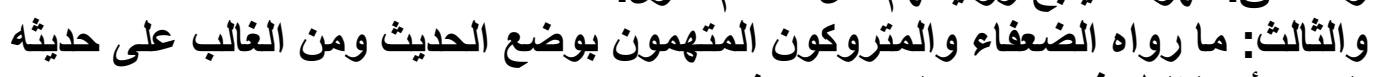

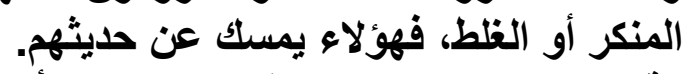

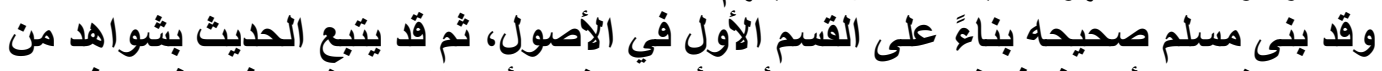

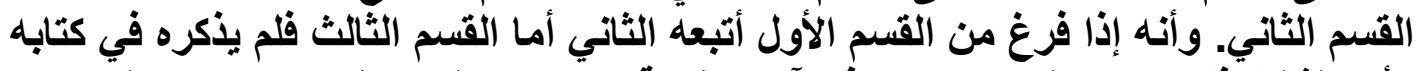

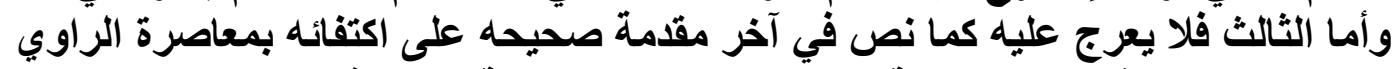

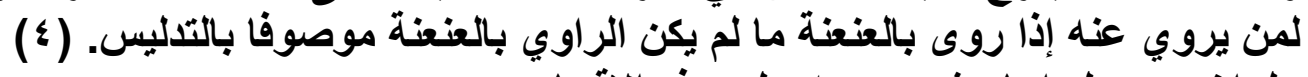

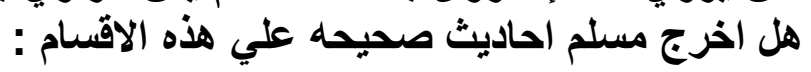

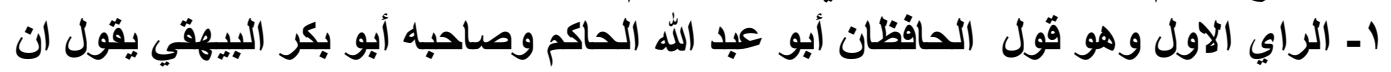

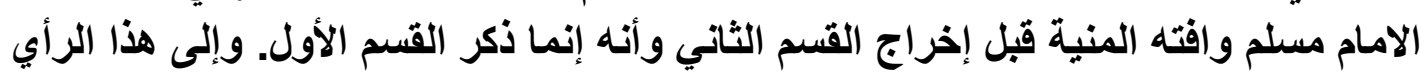

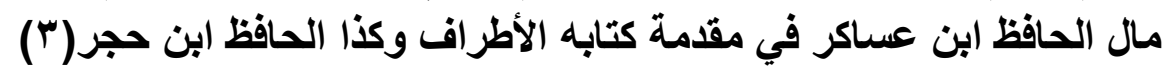
r ـ القول الثاني: رد القاضي عياض هذا القول وقال: (إنه قد ذكر في أبواب كتابه حديث الإن

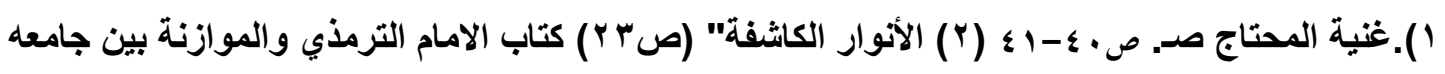

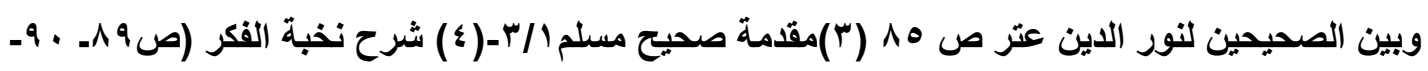

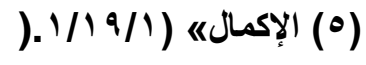




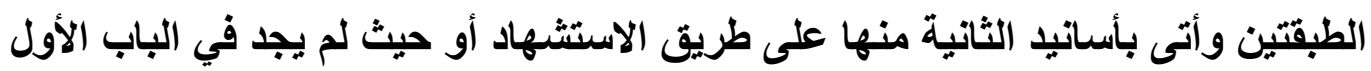

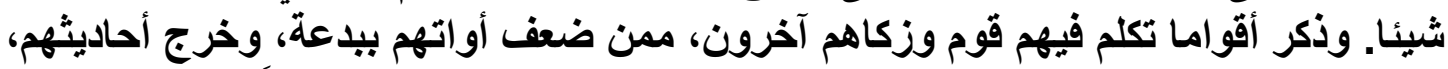

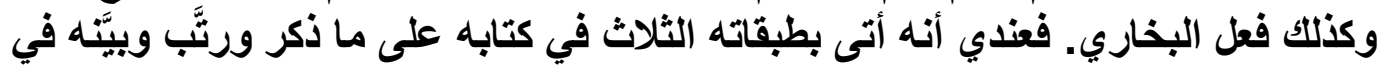

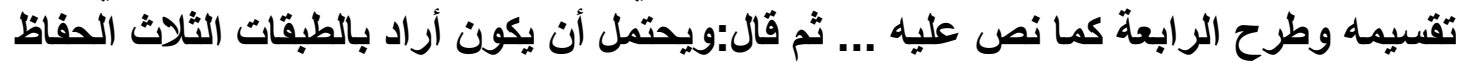

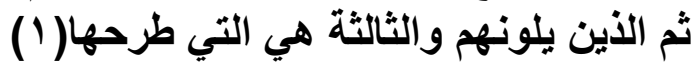

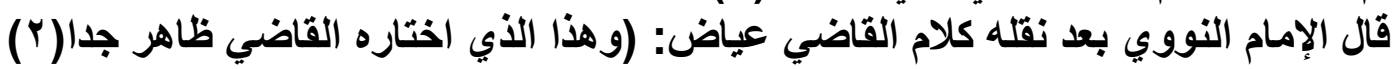

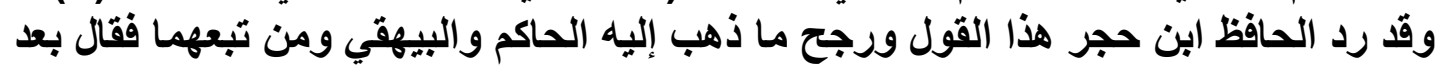

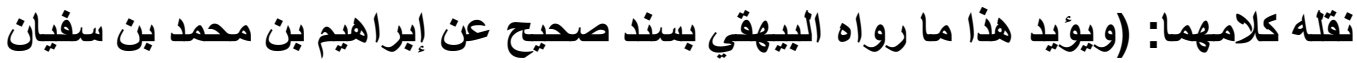

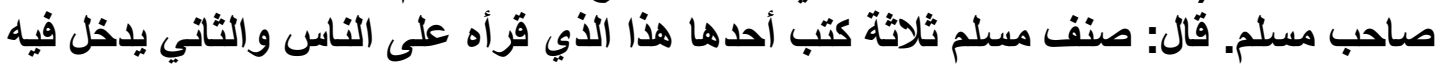

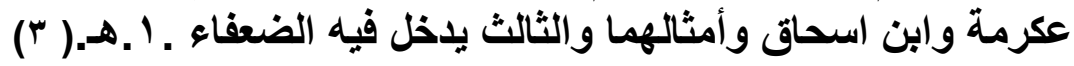

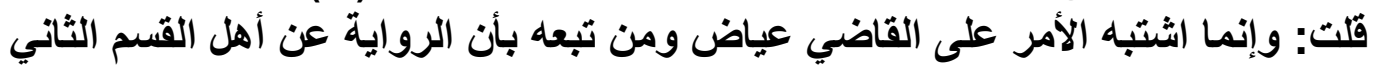

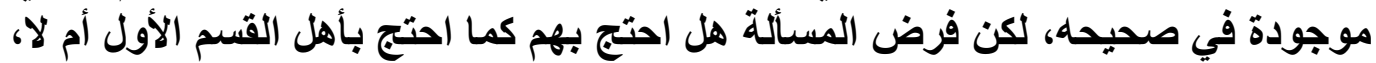

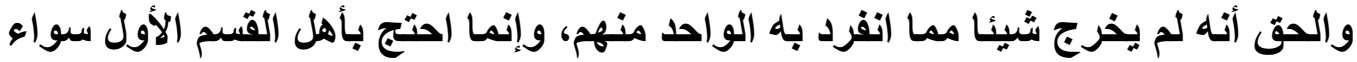

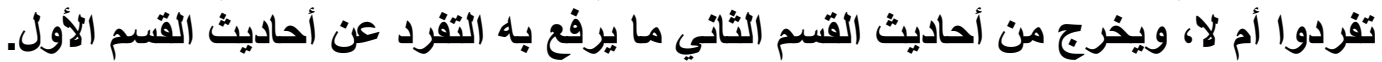

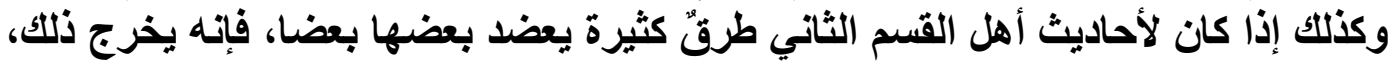

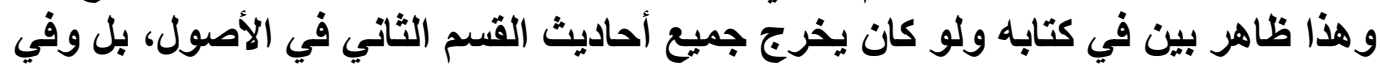

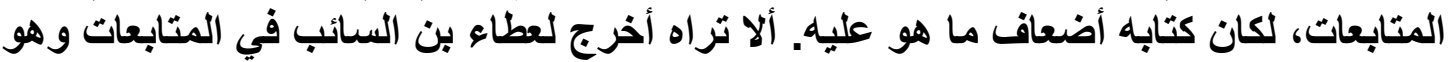

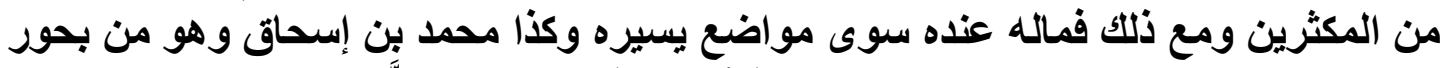

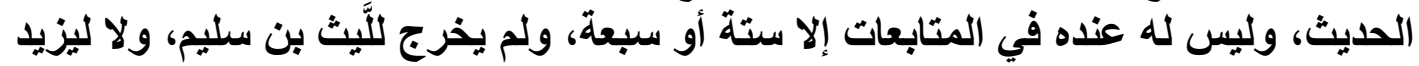

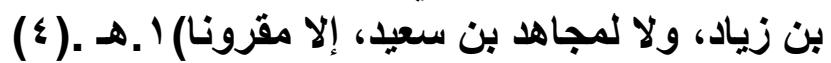

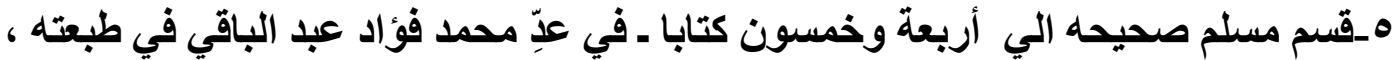

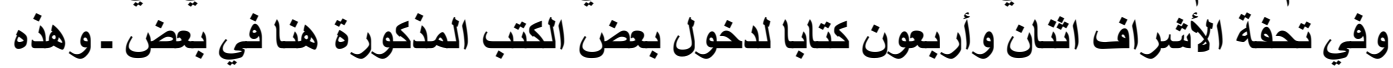

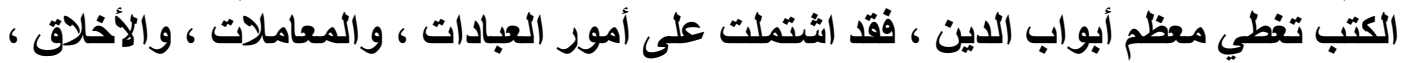

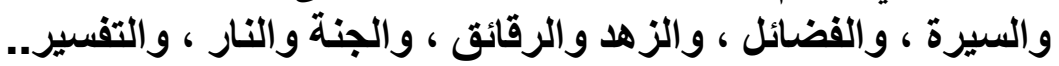

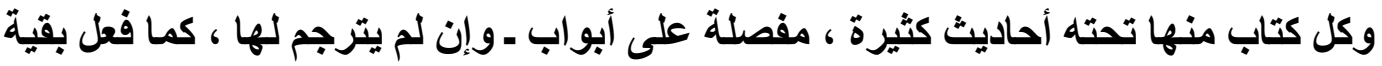

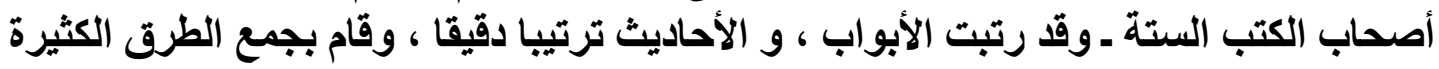
للحديث في مكان واحد ، ويحيل على الألفاظ.

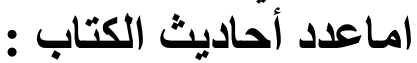

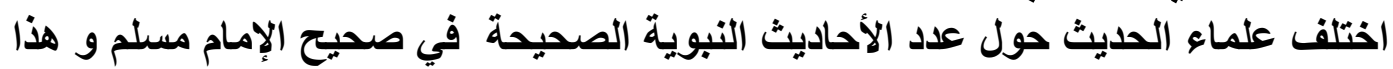

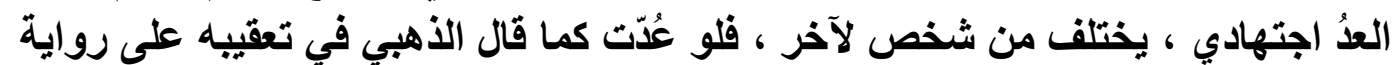

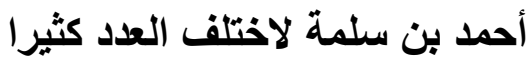
قال النووي : أن عدد أحاديث صحيح الإمام مسلم أربعة آلاف حديث أصول دون المكرر،

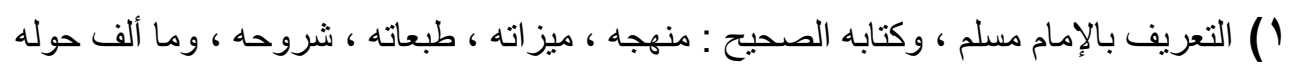

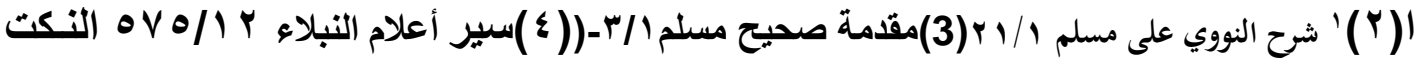




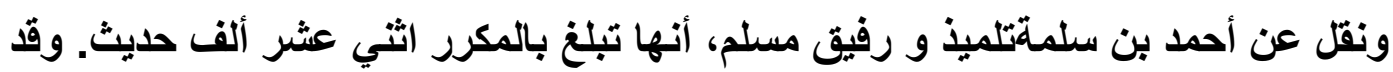

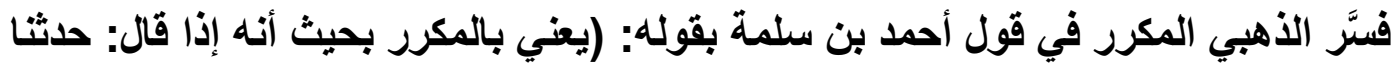

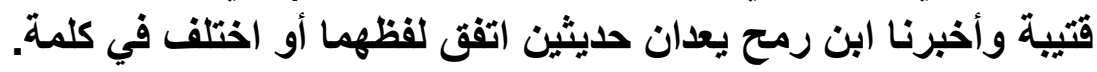

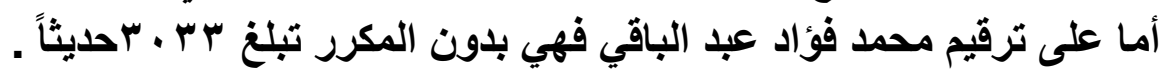

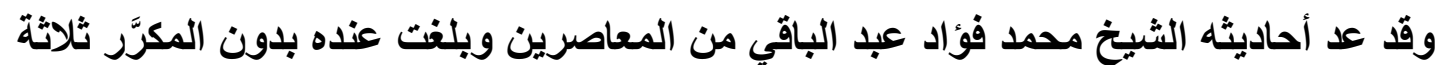

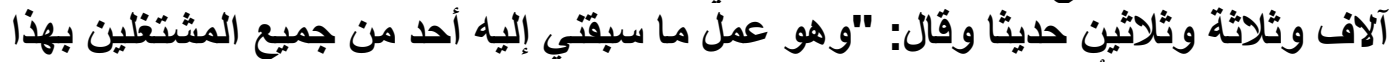

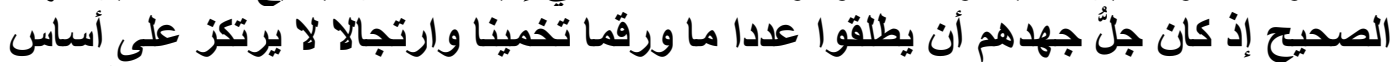

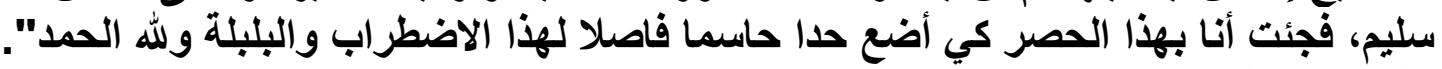
وقيل: غير ذلكي...

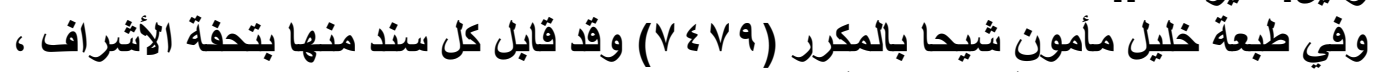

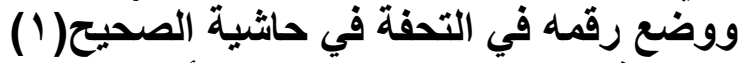

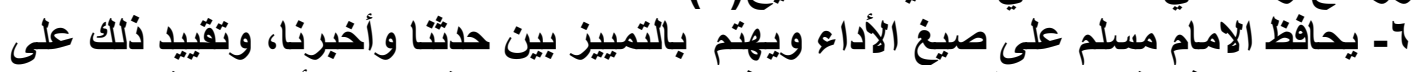

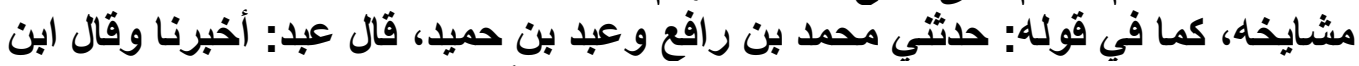

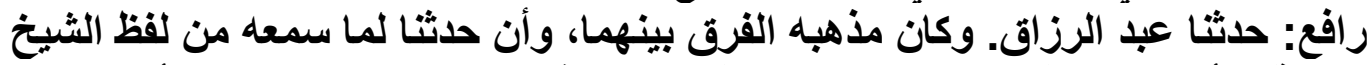

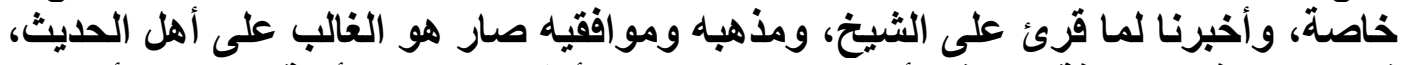

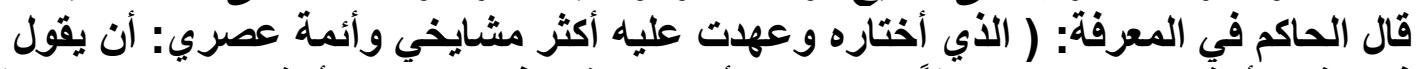

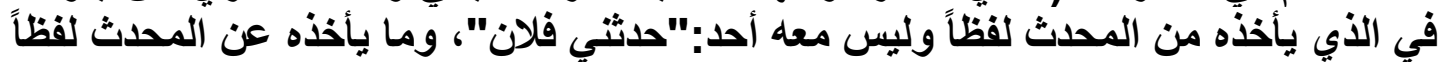

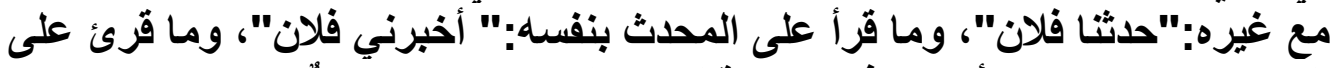

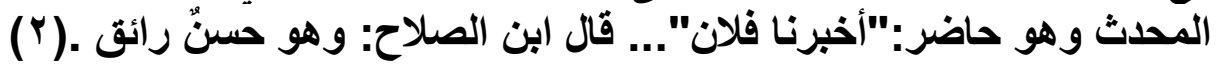

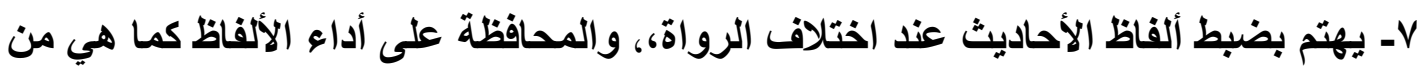

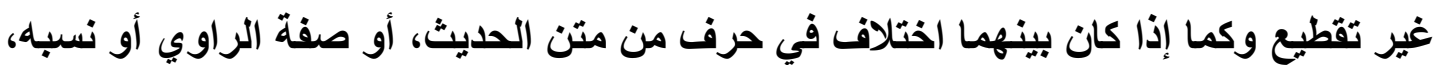

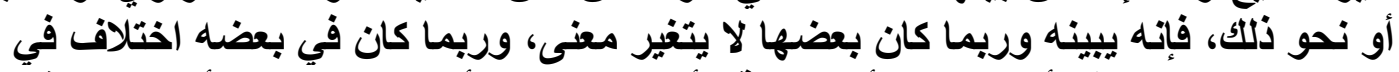

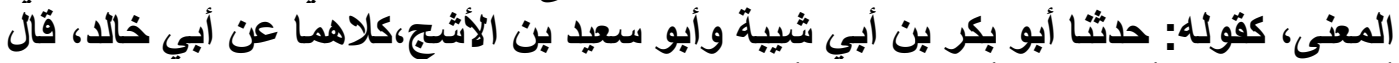

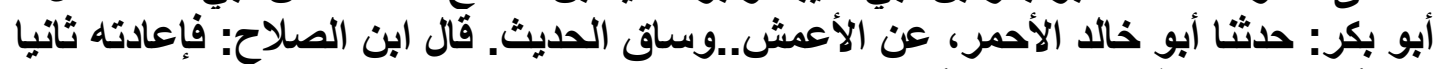

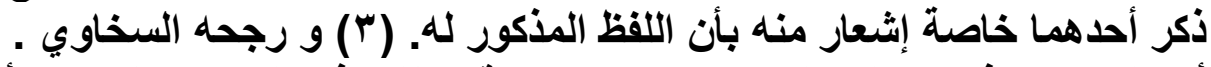

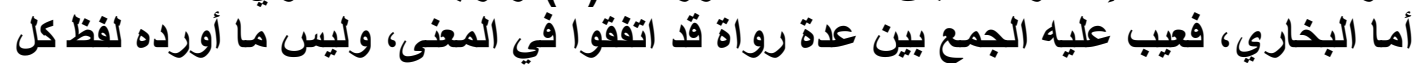

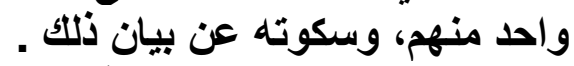

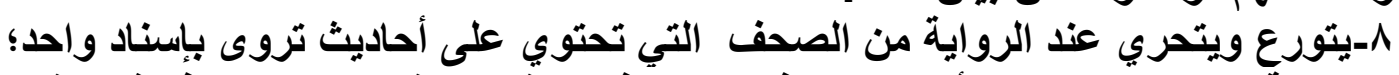

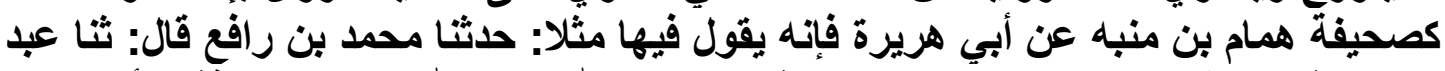

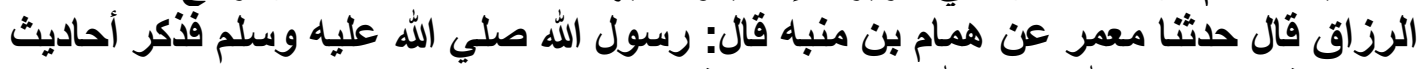

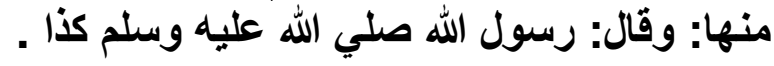

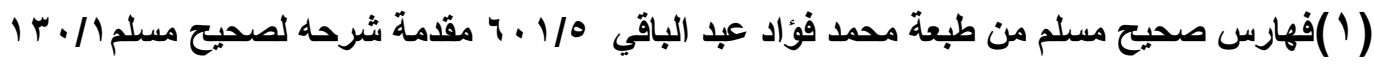

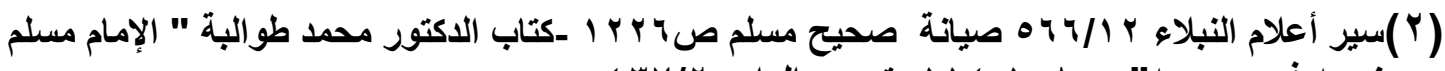

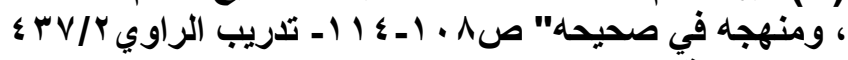

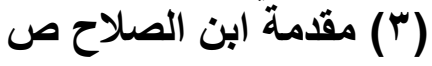


قال ابن الصلاح في صيانة صحيح مسلم: (فتكريره رحمه الله وإيانا في كل حديث منها لقوله:

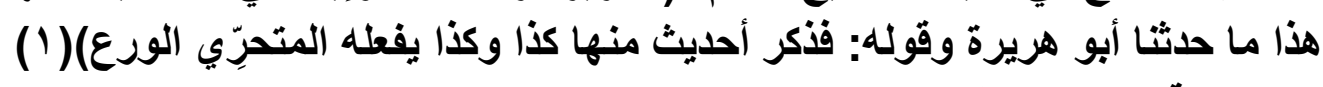

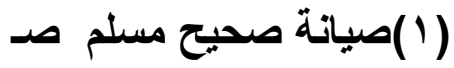
قلت: كثير من العلماءمن يثني علي صنيع مسلم ، ويفضله على البخاري وخاصة المغاربة،

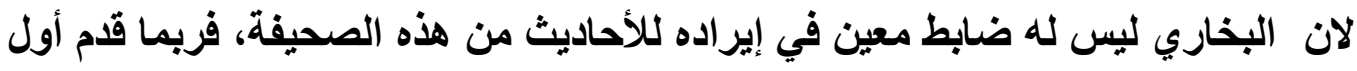

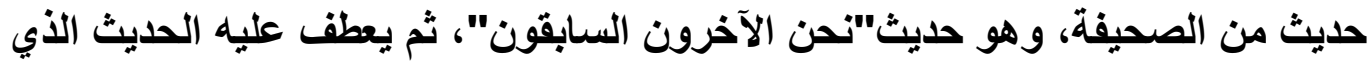

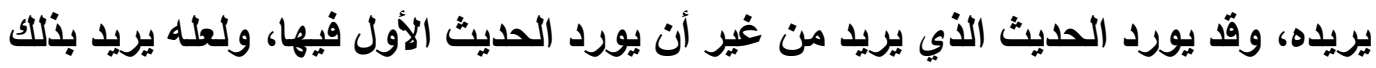

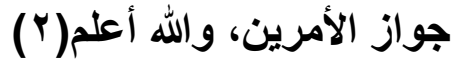

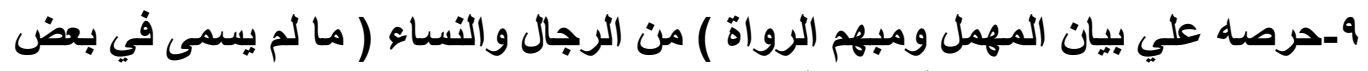

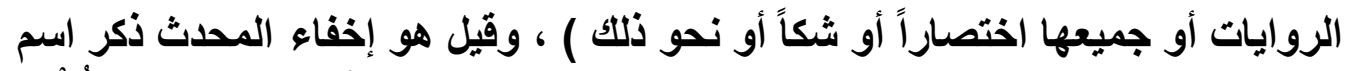

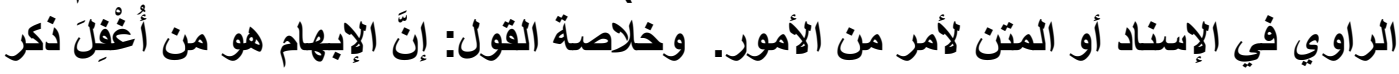
اسمه في الإسناد أو في المتن لأمر من الأمور، وهو الأمون على أنواع سنأتي على بيانها لاحقاً. وهو مهم ، وفائدة البحث عنه زوال الجهالة التي يرد الخبر معها ، حيث يكون الإبهام في

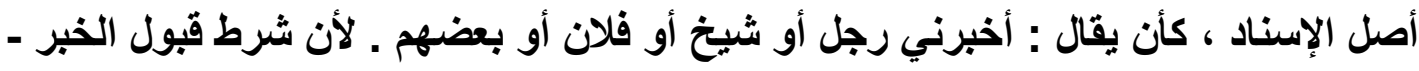

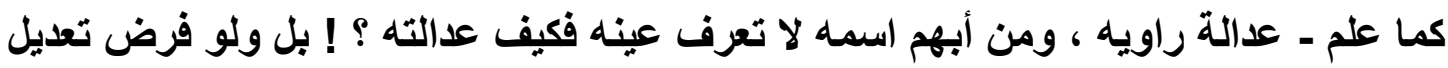

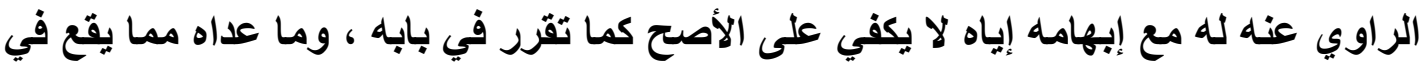
أصل المتن ونحوه

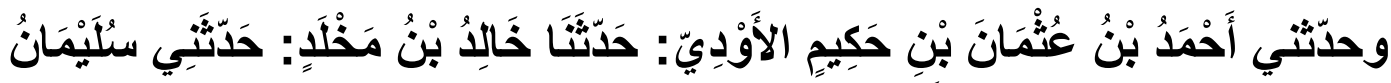

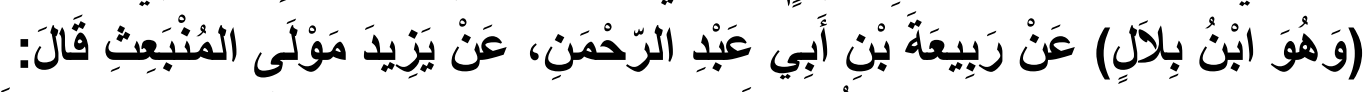

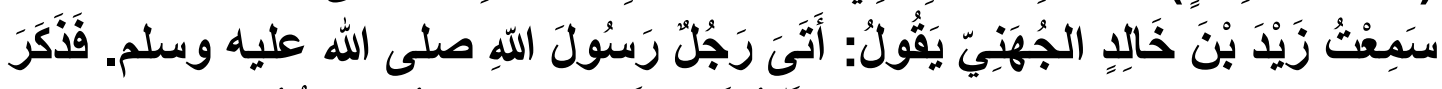

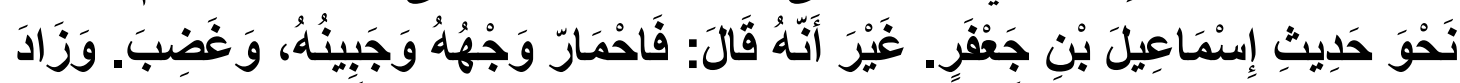

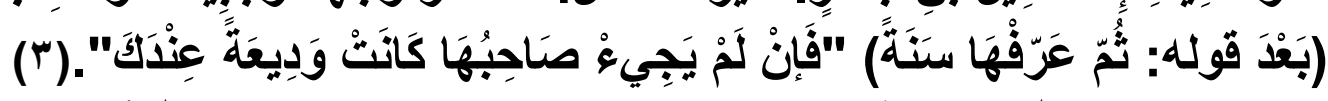
كقوله حدثنا عبد الله بن سلمة حدثنا سليمان يعني بلال. ولم يستجز رحمه الله أن يقول

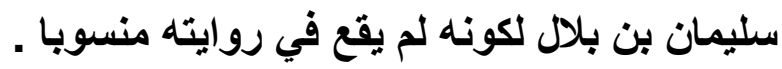

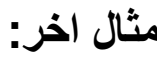

فقي المتن ( كامرأة ) سألت النبي صلى الله عليه وسلم عن غللها ( في الحيض ) فقال لها :

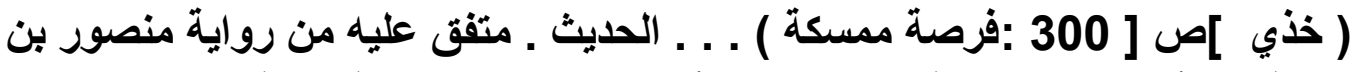

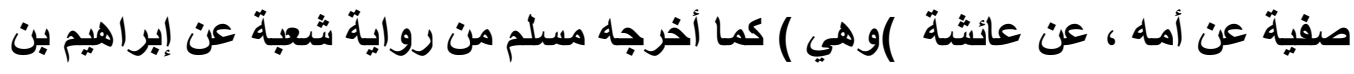

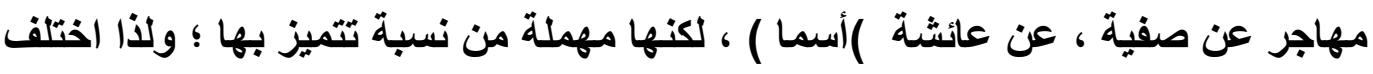

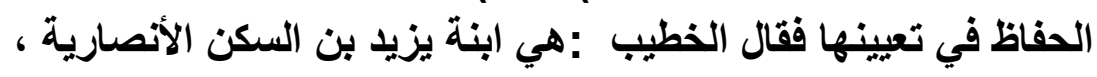

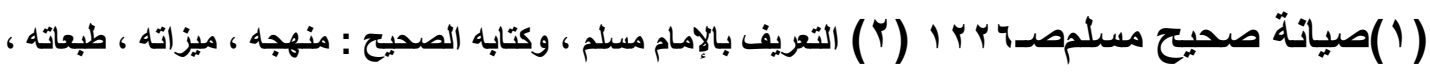
شروحه ، وما ألف حوله.(r)صحيح مسلم كتاب اللقطة 


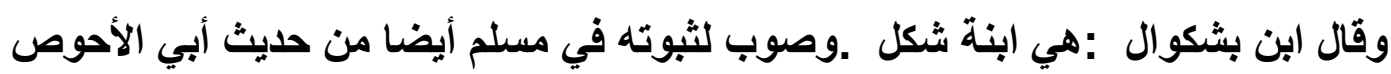

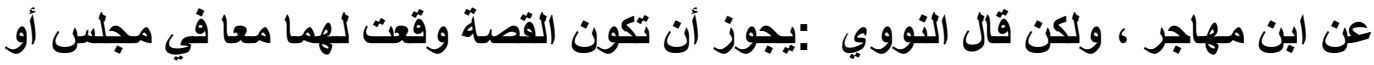

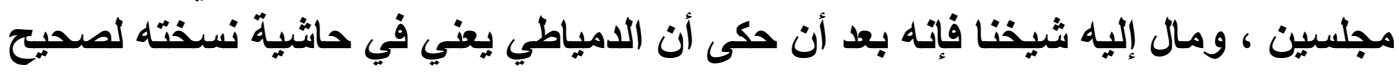

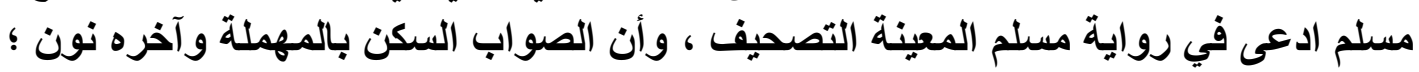

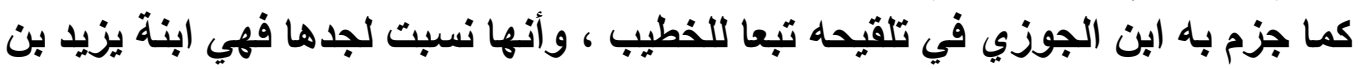

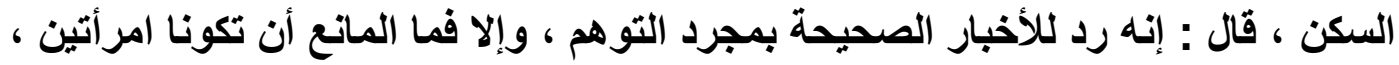

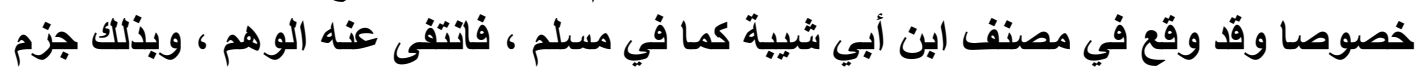

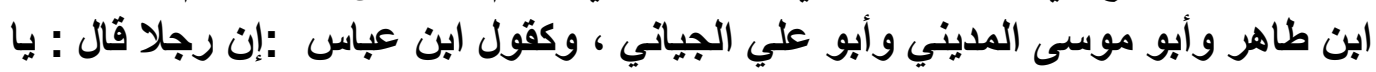

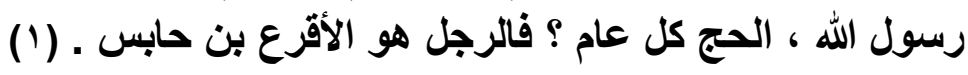

• 1 - يسوق مسلم الحديث في مكان واحد ، و يجمع طرقه ويتحاشي التكرار إلا نادرا وإذا

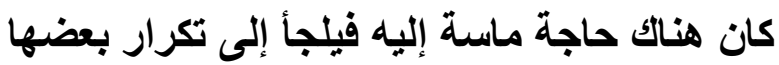

قال في المقدمة: (على غير تكرار إلى أن يأتي موضع لا يستغنى فيه عن ترداد حديث فيه

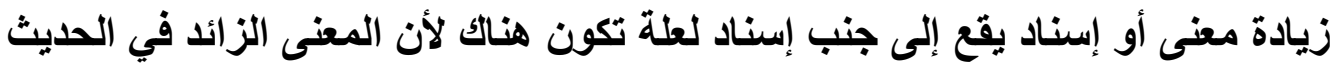

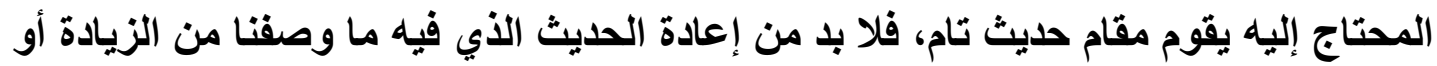

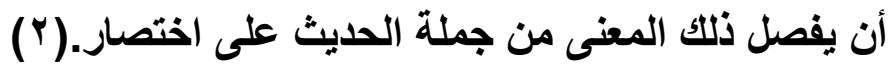
كما في حديث ابن عباس في قصة مجيء وفد عبد قيس فإنه ذكره في كتاب "الإيمان" وكرره في كتاب "الأشرية".

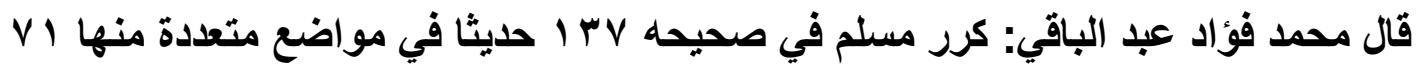

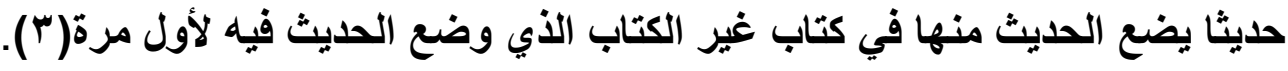

قال الإمام السخاوي في ختمه على صحيح مسلم: وقد قال الإمام أبو محمود المقدسي فيما

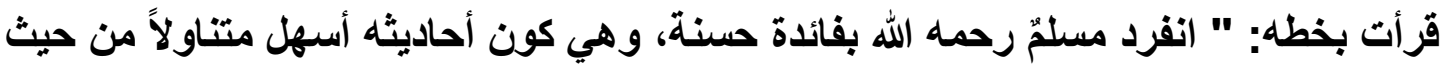

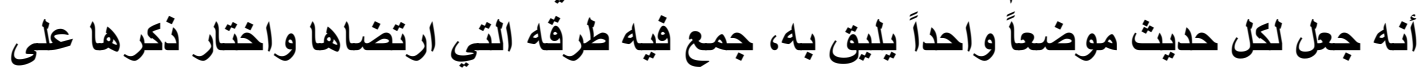

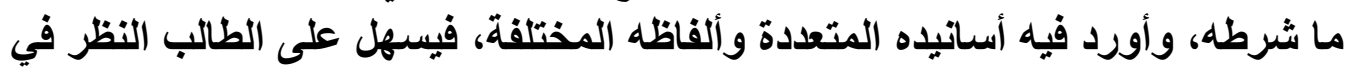

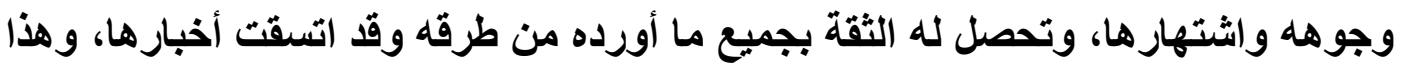

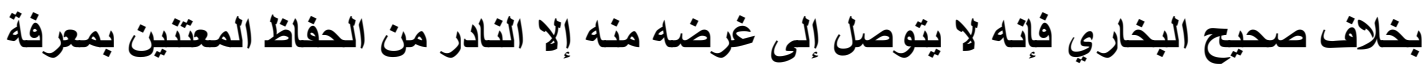

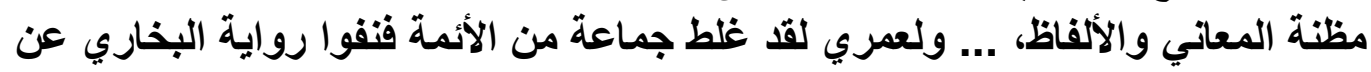

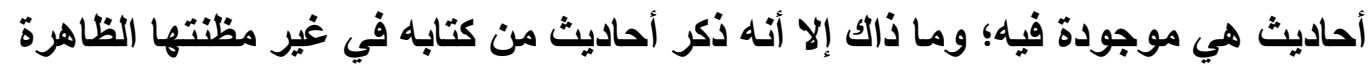

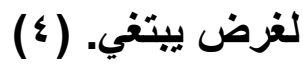

$$
\begin{aligned}
& \text { (1) }
\end{aligned}
$$

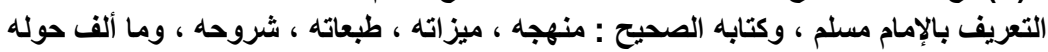

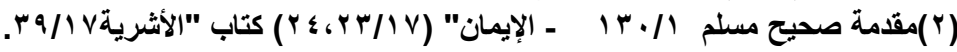

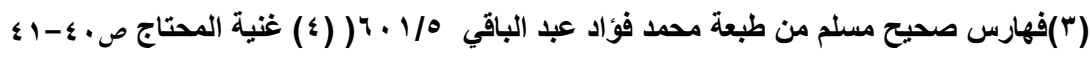

ال-- تلخيص الطرق وتحوُل الأسانيا، مع إيجاز العبارة وكمال حسنهاوالجمع بين الشيوخ: و

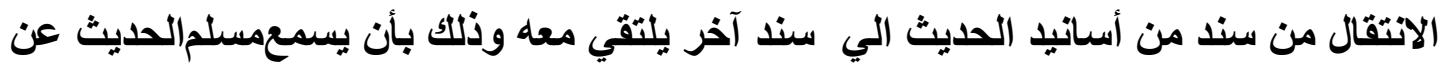
شيخين أو أكثر من شيوخه ويلتقون جميعاعند من فوقهم (شيخ شيخه 
فكان يأكر هم جريعا فيعف الثاني على الأولوالثالث عليهما وهذا.... ثم يذكر بقية الإسناد وفق منهجهالمعتاد فيكون بذلك قد جمـعبينروايتين أو أكثر في سياق واحد.

قال العلامة المعلمي - رحمه الله : (ويميز الألفاظ ، وصيخ الأداء ، وتحويل الأسانيا ،)(1)

مثال: حدثنا أبو بكر بن أيس شيبة ومحمد بن المثني وابن بشار قالوا حدثا محمدبنجفر

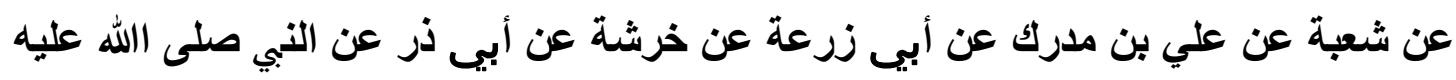

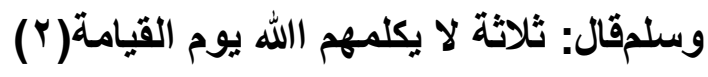

مثال : قال مسلم: حدثنا أبو بكر بن ابي شيبة حدثنا أبو أسامة ح وحدثنا ابن نمير حدثنا

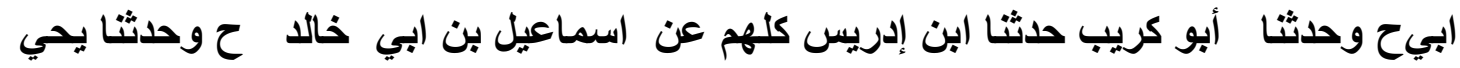

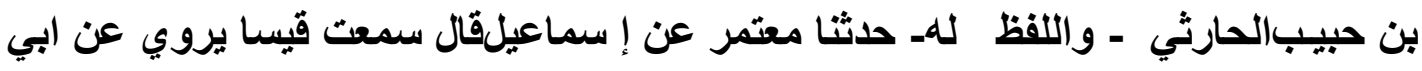

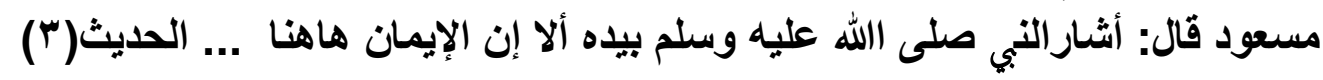
فهنا نلاحظ كيف أن مسلما قد جمع بين أربعة أحاديث كلها في سياق واحد فوضع حرف ح تثلاث مرات. r أعتماده الشهرة في ترتيبه؛ فيفضل الحديث الأي اشتهر بين الثقات على الحديث الأي لم

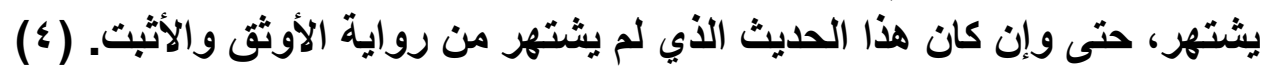
مسلم لا يحتج بالوحدان:

ليس في صحيح مسلم حديث أصل من رواية من ليس له إلا راو واحد أبداً. وليس في صحيح البخاري إلا حديث واحد عن تابعية من الوحدان.

ب ا ـ مراعاة التسلسل؛ كأن يكون رواة الحديث كلهم من أهل بلا واحد، أو قبيلة واحدة، فيقدم

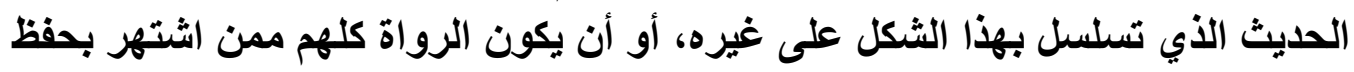

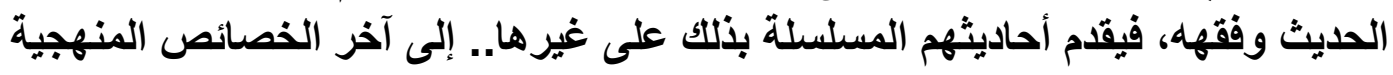

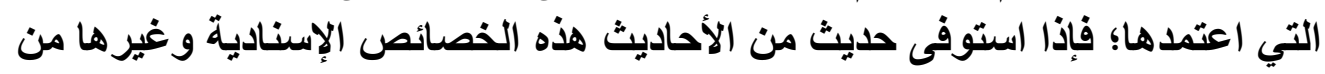
المرجحات التي لا تحصى؛ يكون ذلتك الحديث أسلم وأنقى من غيره الاحيث.

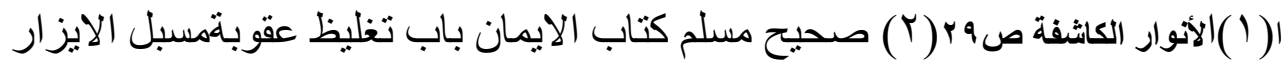

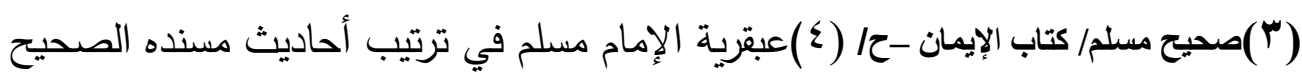

$$
\begin{aligned}
& \text { المؤلف : حمزة المليباري }
\end{aligned}
$$

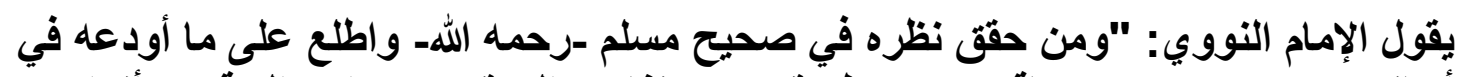

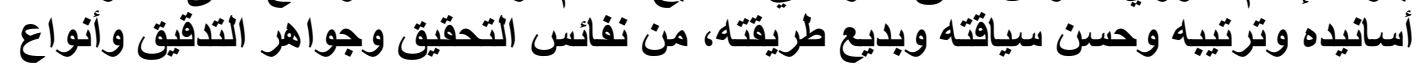




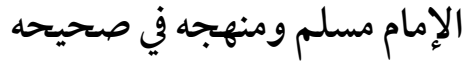

الورع والاحتياط والتحري في الرواية وتلخيص طرقه واختصار ها وضبط متفرقها واتتشارها

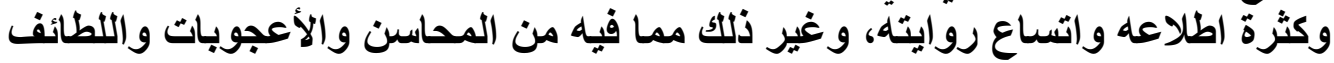

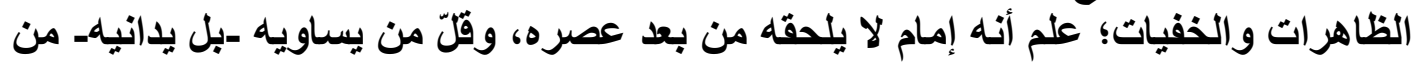

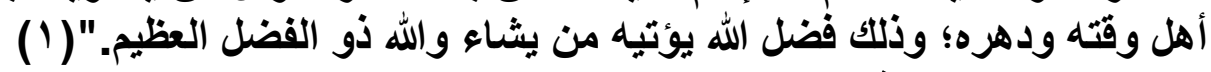
ع أشروط مسلم في صحه ودميحه:

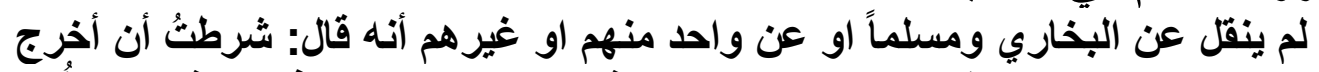

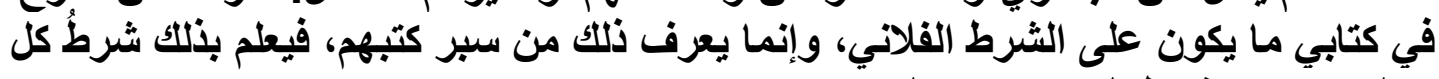

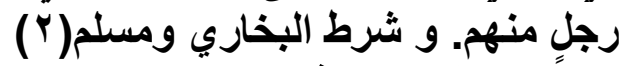

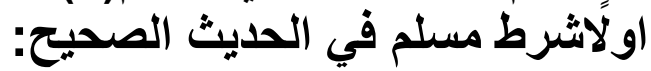

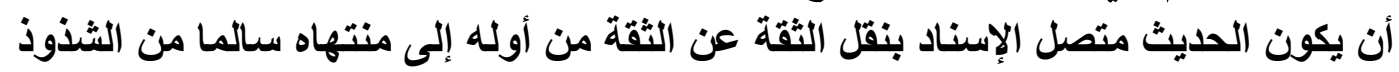

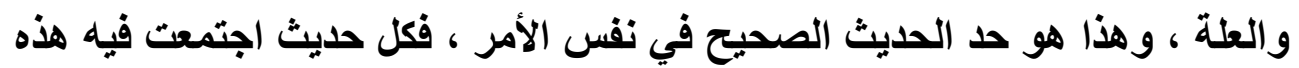

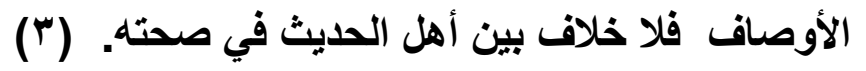

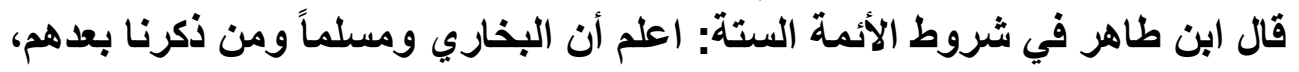

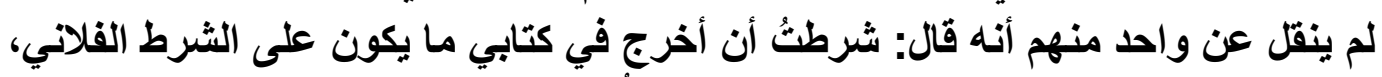

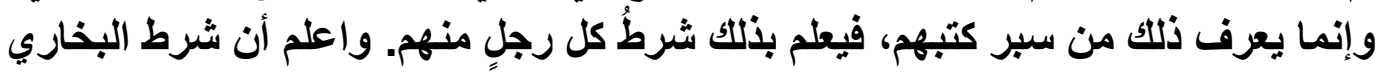

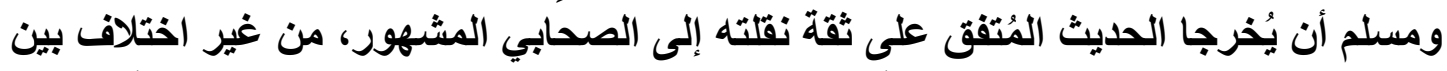

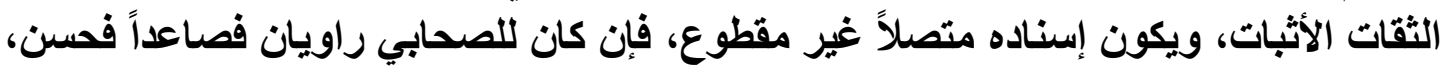

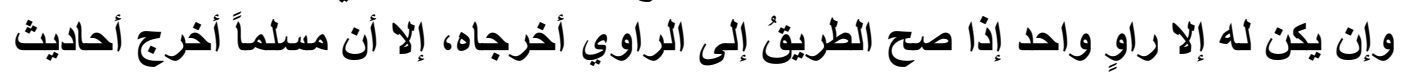

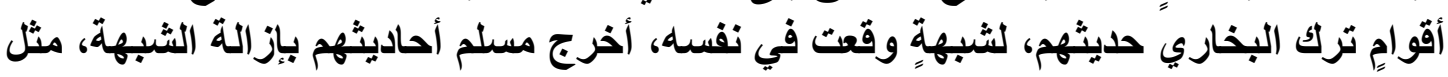

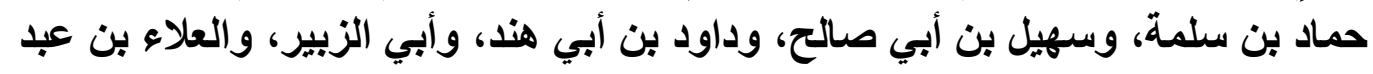

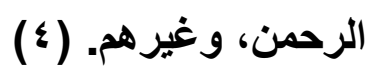

وقال الحازمي في شروط الأئمة الخمسة: مذهب من يخرج الصحيح أن يعتبر حال

الراوي العدل في مشايخه وفيمن روى عنهم، وهم ثقات أيضا، وحديثه عن بعضهم صحيح

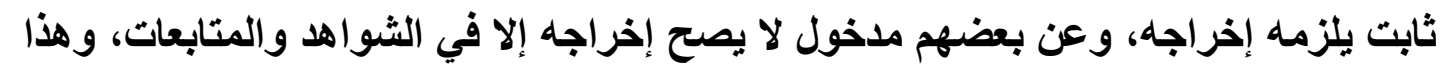

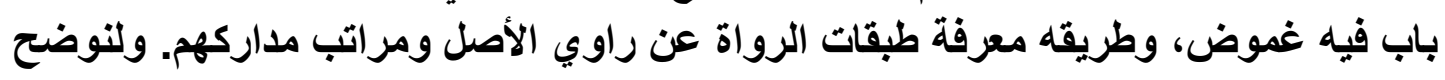

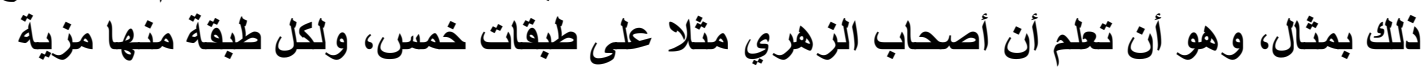

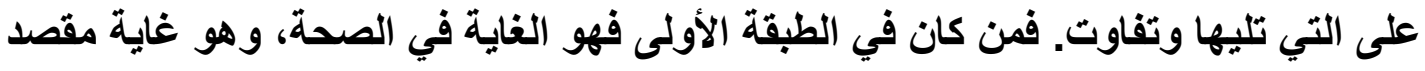

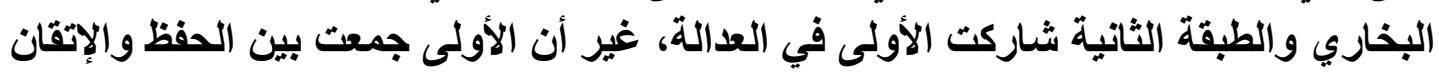

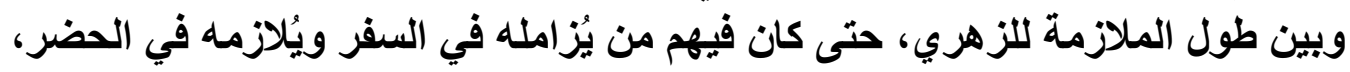

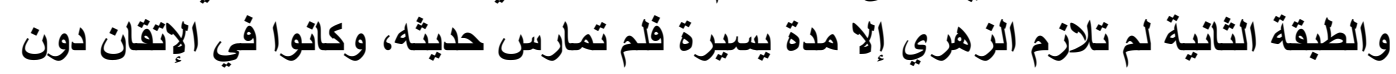

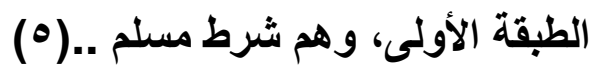

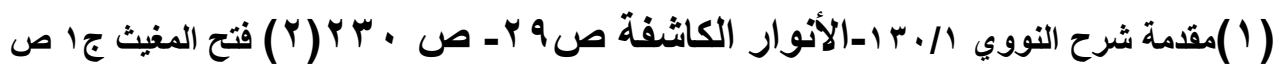

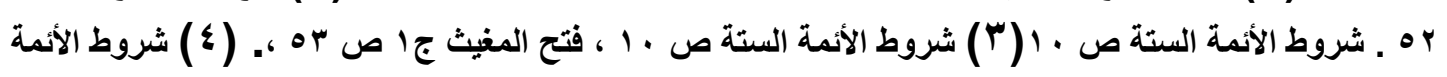

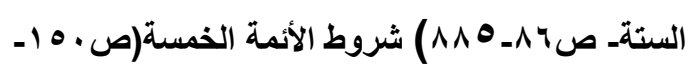

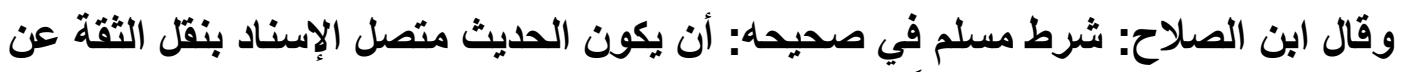

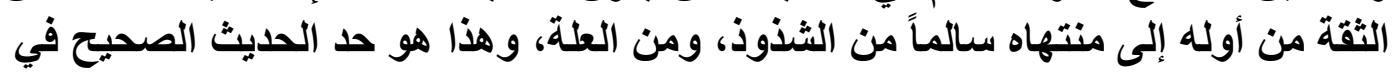

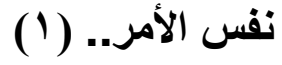




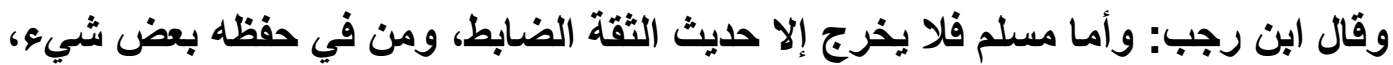

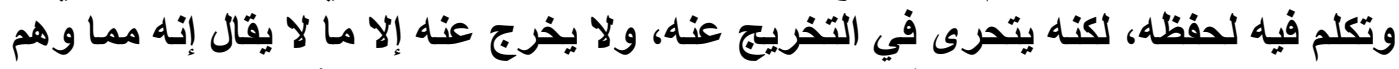

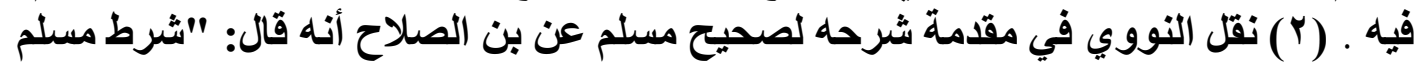

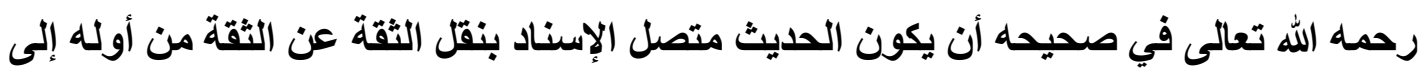

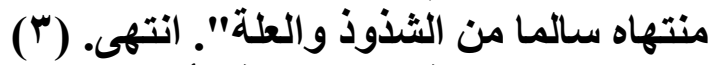

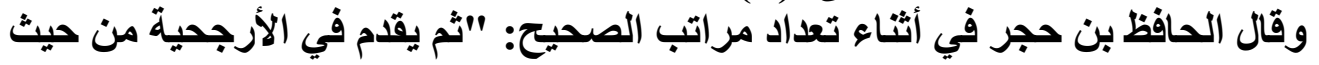

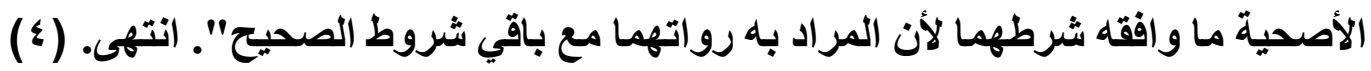

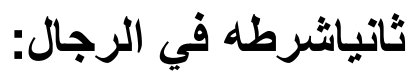

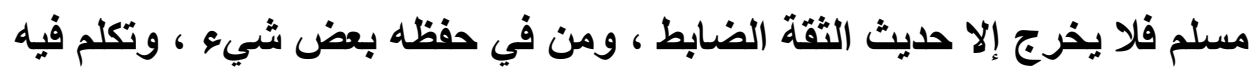

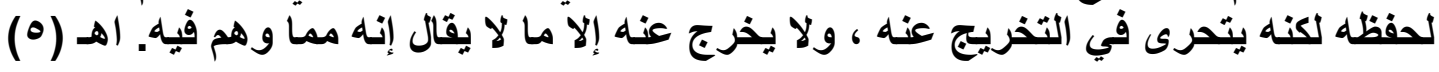
وقال شيخ الإسلام ابن تيمية:

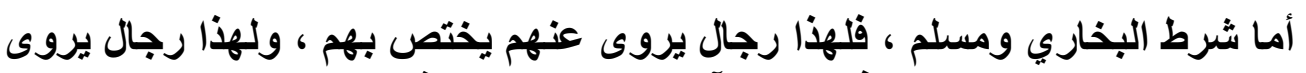

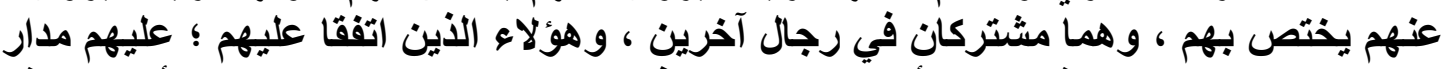

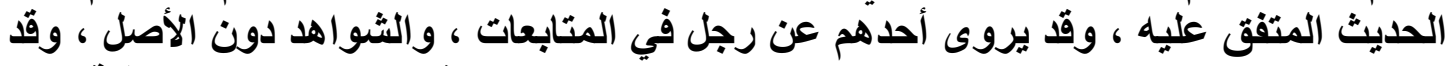

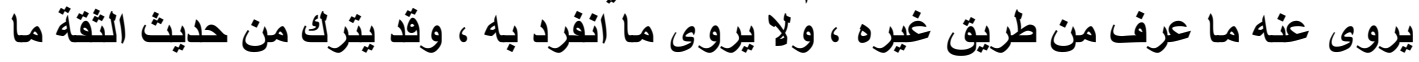

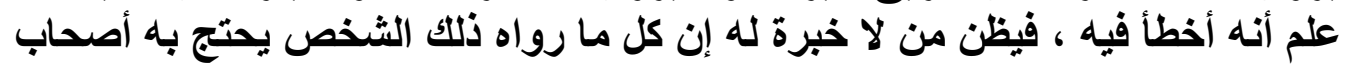

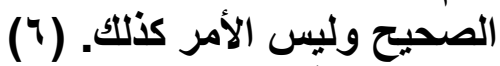

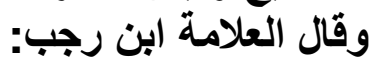

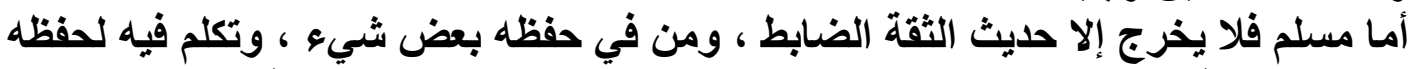

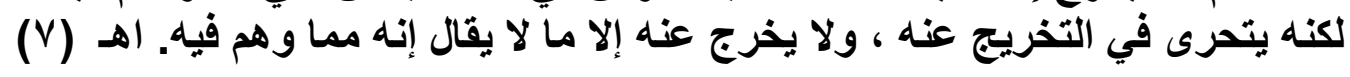

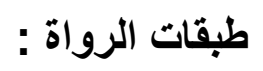

الطبقة الأولى فهو الغاية في الصحة، وهو غاية مقصد البخاري جمعت بين الحفظ والإتقان

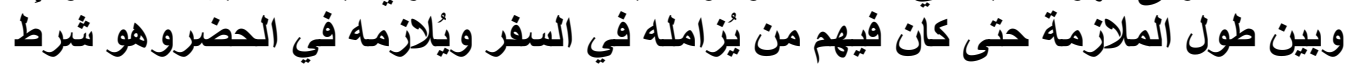

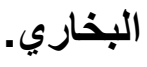

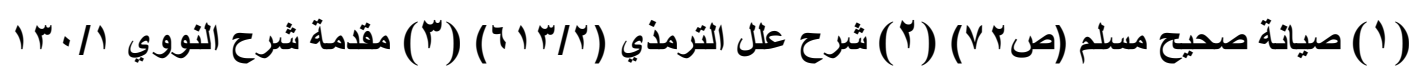

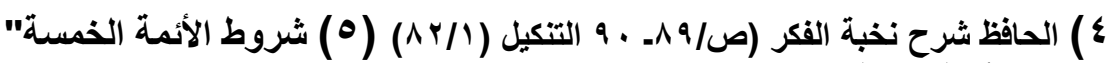

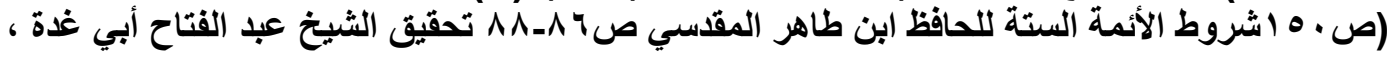

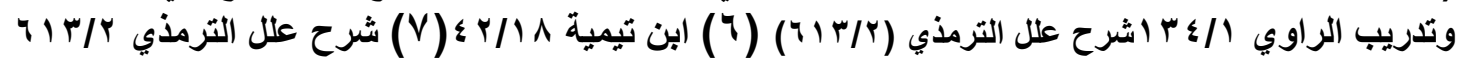




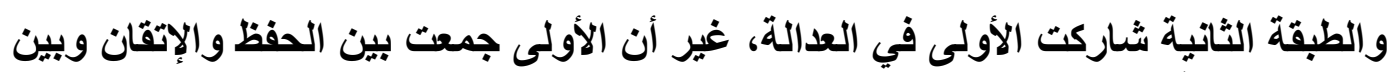

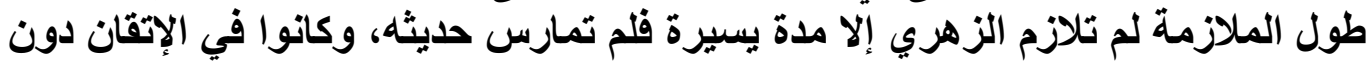

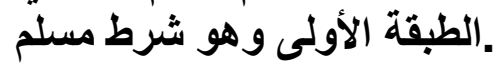

والطبقة الثالثة: جماعة لزموا الزهري مثل أهل الطبقة الأولى، غير أنهم لم يسلموا من غوائل . الجرح، فهم بين الرد والقبول، وهو شرط أبي داود والنسائي.

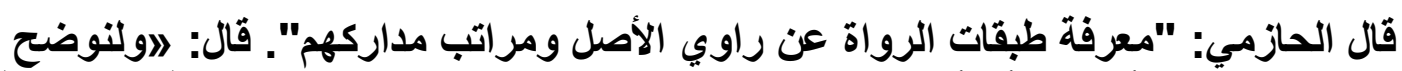

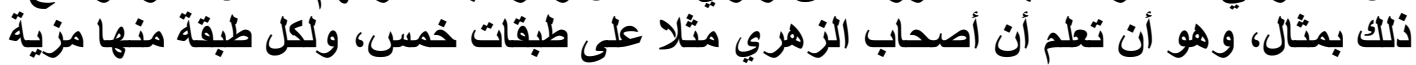

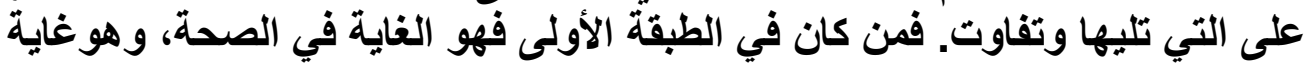

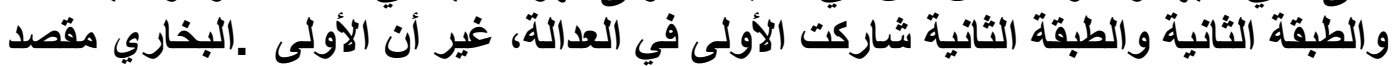

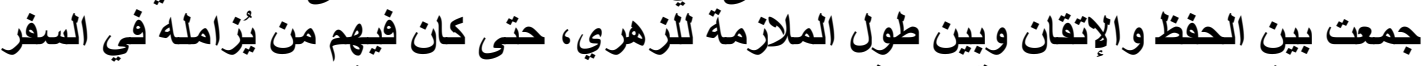

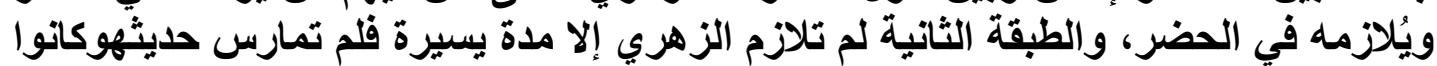

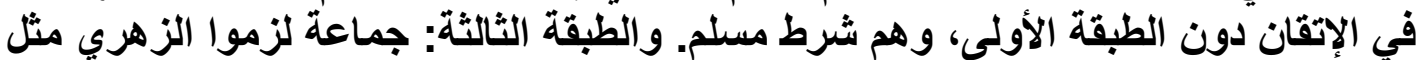

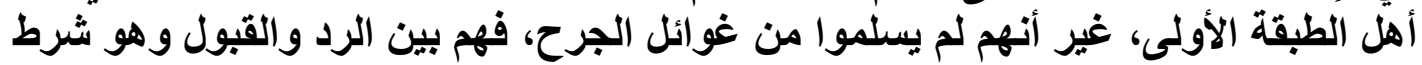
أبي داود والنسائي (1)

هل شرط مسلم في المقدمة هو شرطه في صحيحه.

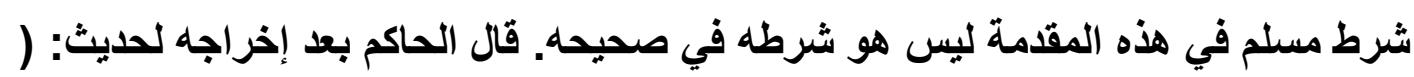

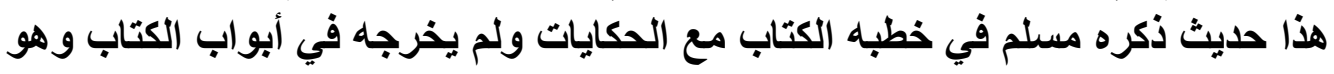

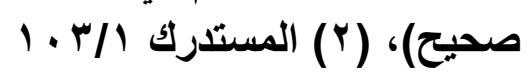

وقال ابن القيم في في معرض ردده على مخالف له: (وأما قولكم إن مسلم روى لسفيان بن فئن

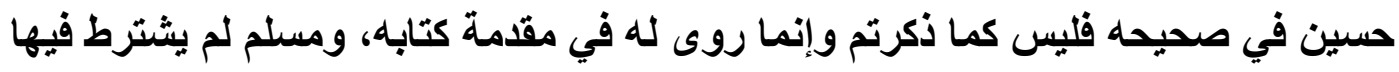

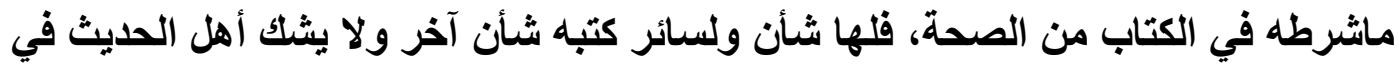

ذلتك(r)

ومما يال على صحة التفريق في الثرط بين الصحيح والمقدمة أن أصحاب كتب التراجم

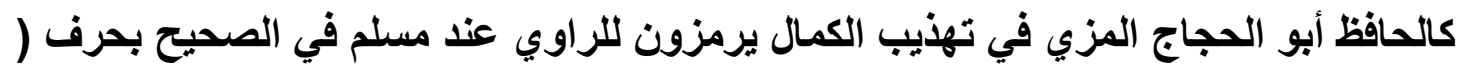

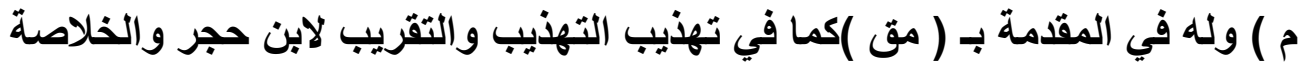

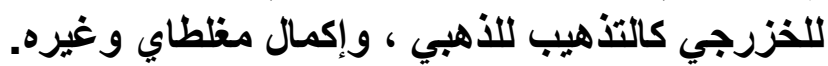

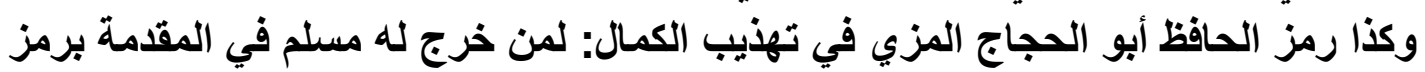

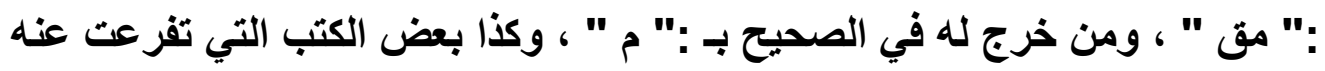

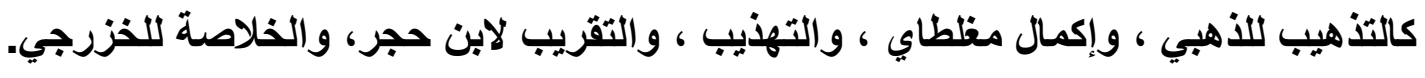

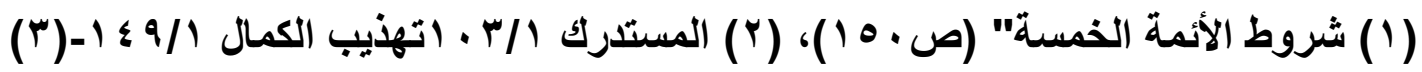

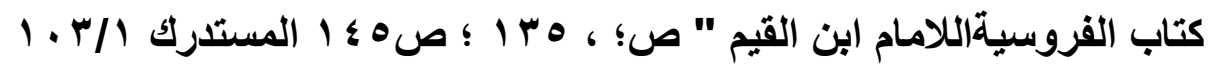




\section{هل يكتفي مسلم بالمعاصرة:}

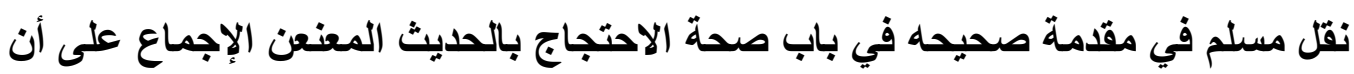

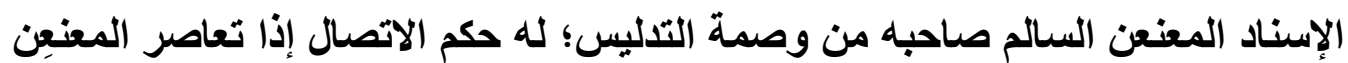

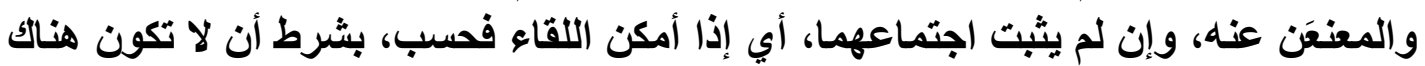

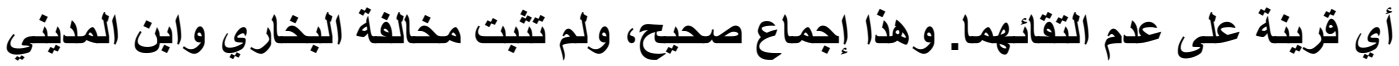

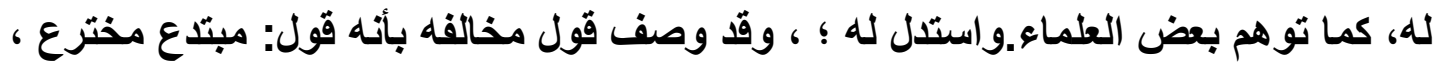

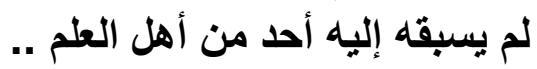

فقال رحمه الله: (وهذا القول يرحمك الله في الطعن في الأسانيد، قول مخترع مستحدث، غير

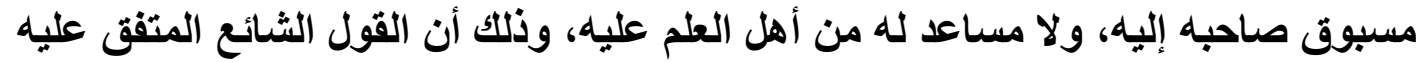

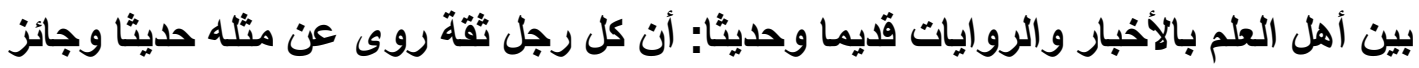

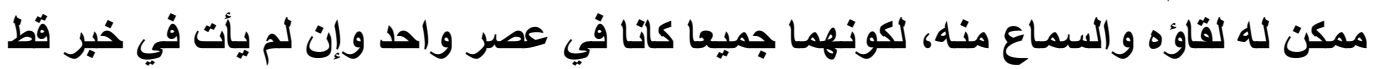

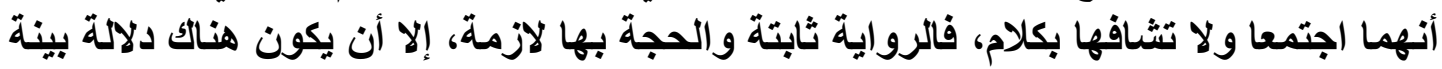

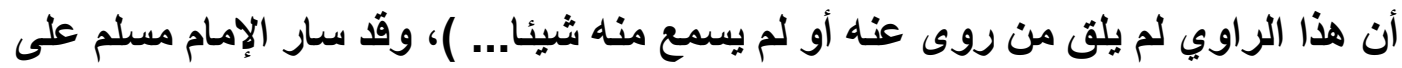

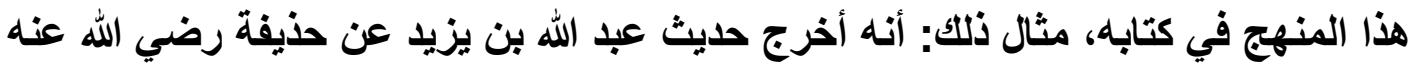

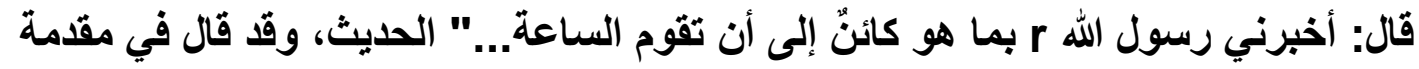

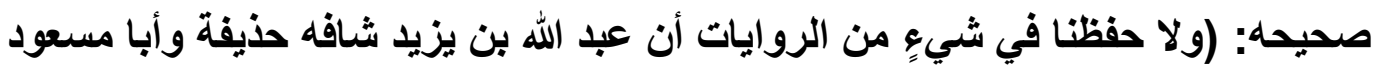

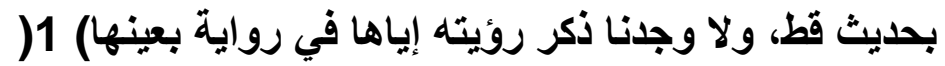

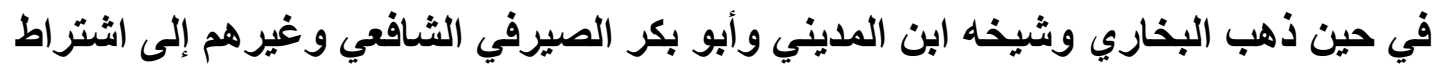

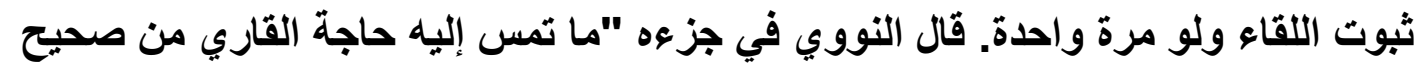
البخاري": (وهذا أقوى)، وقد أظهره البخاري في التاريخ وجرى ولت عليه في الصحيح .

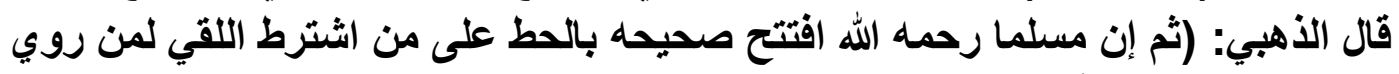

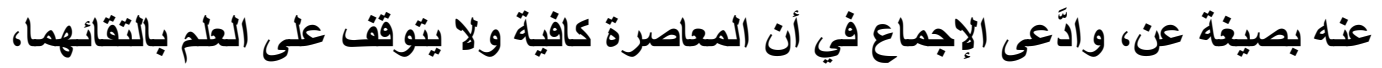

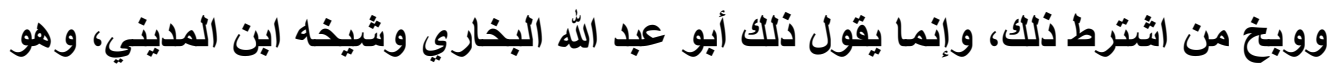

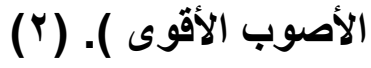

وقال ابن رجب: (وما قاله ابن المديني والبخاري، هو مقتضى كلام أحمد وأبي زرعة وأبي

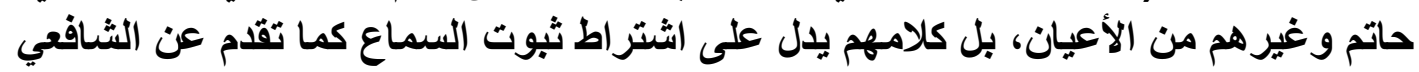
( أهـ.كن فرض المسألة؛ هل عمل مسلم بهذه القاعدة في صحيحه أولا ؟ (r )

قال النووي في مقدمة شرح مسلم: (وإن كنا لا نحكم على مسلم بعمله في صحيحه بهذا

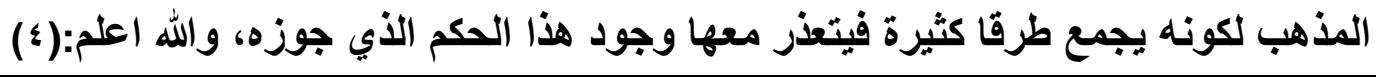

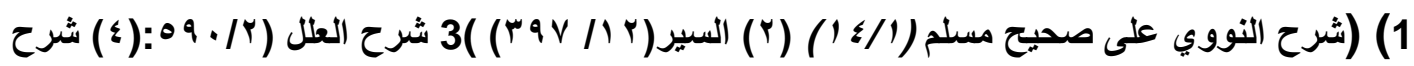

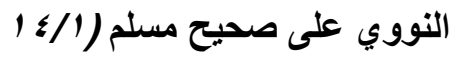




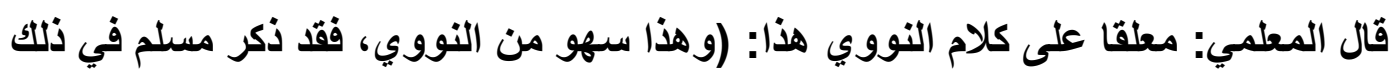

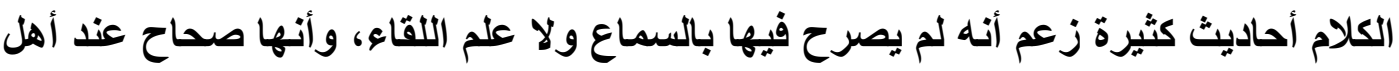

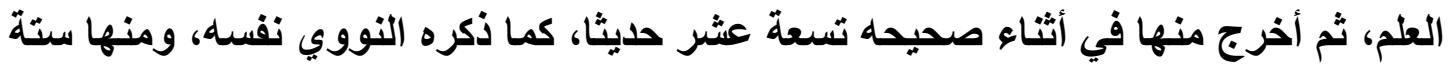
في صحيح البخاري كما ذكره النووي أيضا ( )

فاختلف فيمن أراد الإمام مسلم رحمه الله عليه على أقوال :

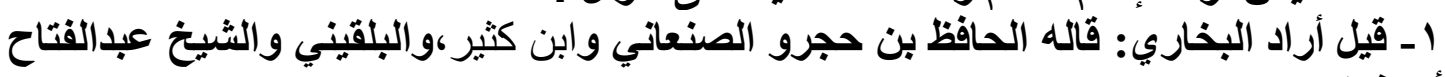

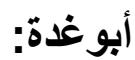

قال الحافظ بن حجر: (واكتفى مسلم بمطلق المعاصرة و ألزم البخاري بأنه يحتاج إلى ألا يقبل

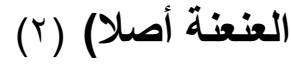

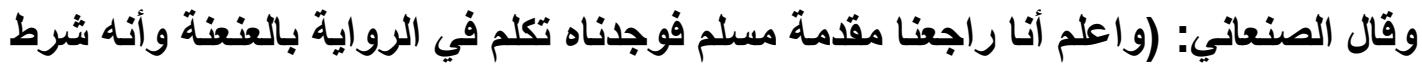

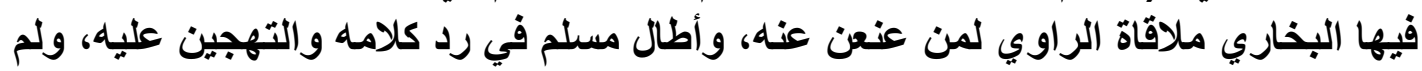

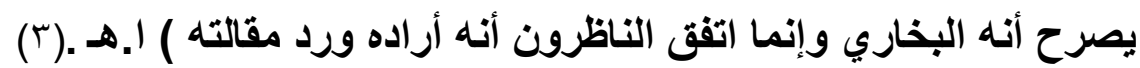

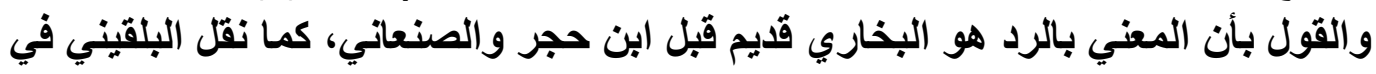

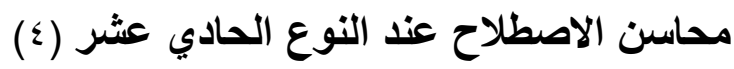

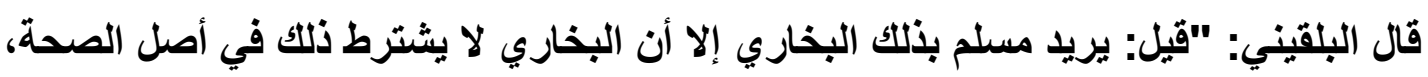

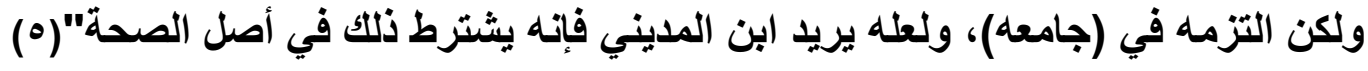

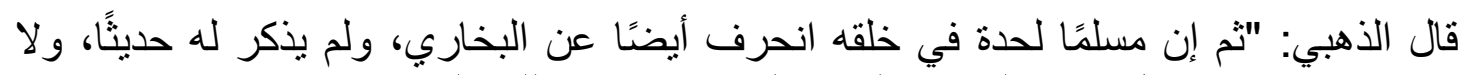

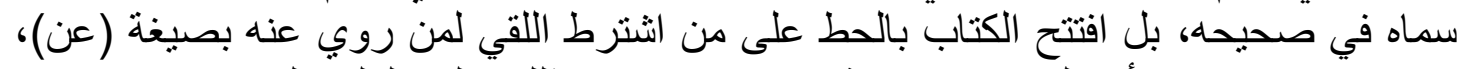

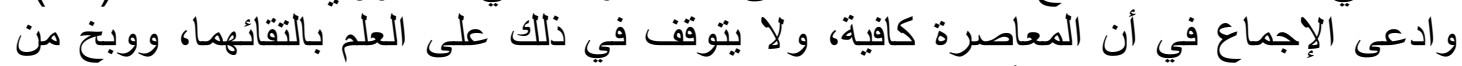

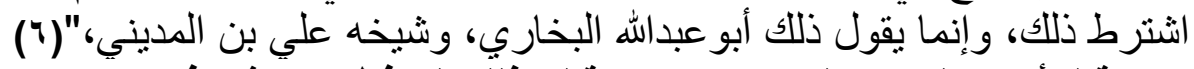

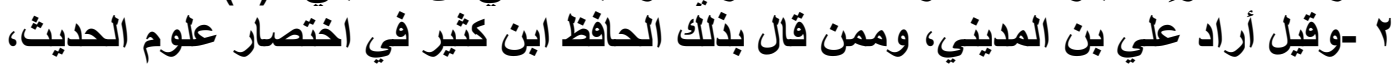

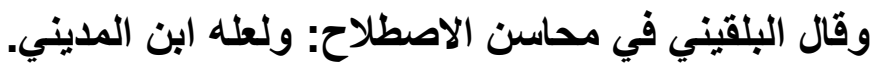

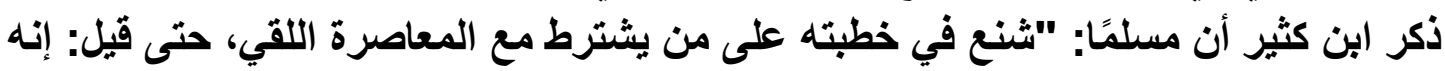

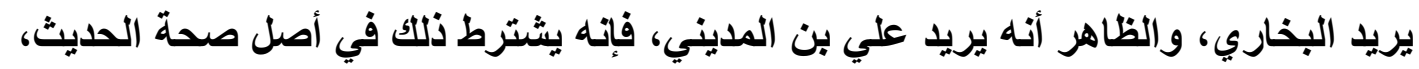

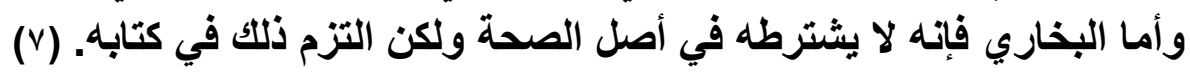
قال البقيني: "قيل: يريد مسلم بذلك البخاري إلا أن البخاري لا يثترط ذلك في أصل الصدة الصدة،

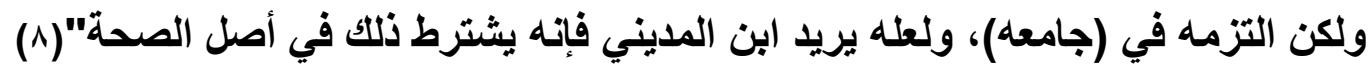
ونقل البقاعي في النكت الوفية عن شيخه ابن حجر ما يخالف ما في النزهة. فقال في مبحث

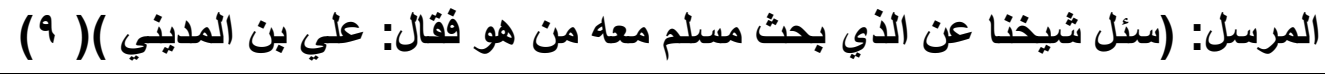

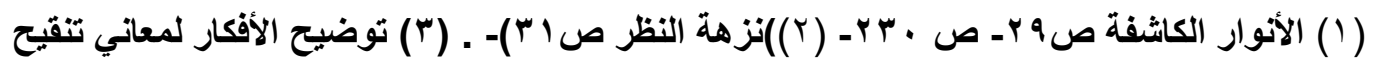

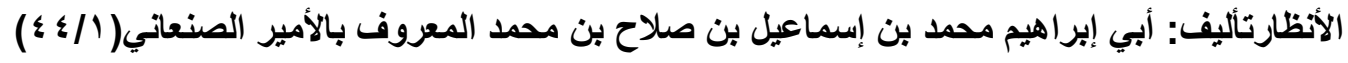

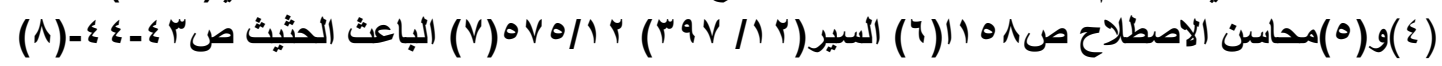

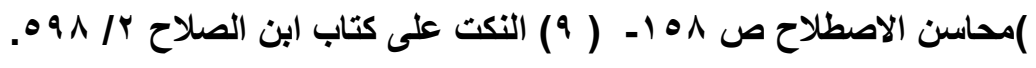


r- ويحتمل أنه أراد الاثنين معا أو أكثر

قال الشيخ المعلي: " قيل: إنه أراد البخاري، ولا مانع من أن يريله هو، وشيخه ابن

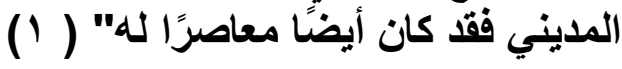

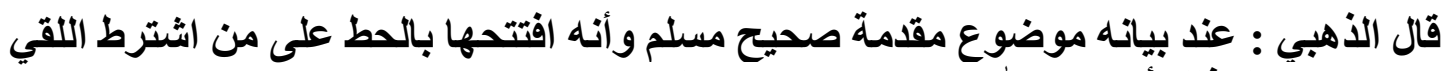

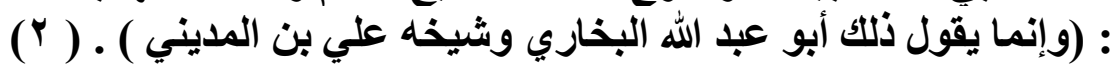

وقد ذكر ابن رجب في شرح العلل أن ما قاله البخاري وابن المديني هو مقتضى كلام الأئمة

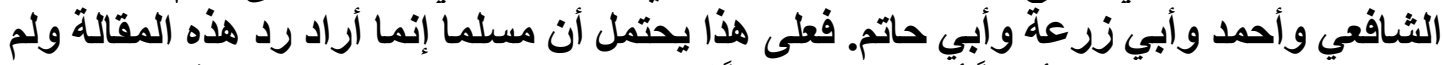

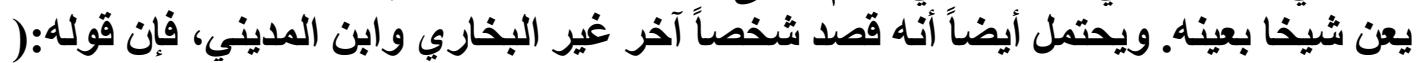

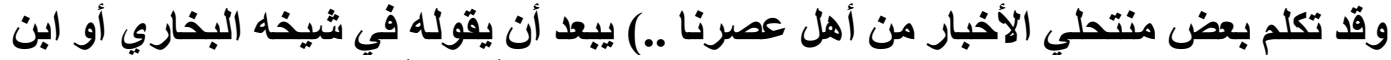

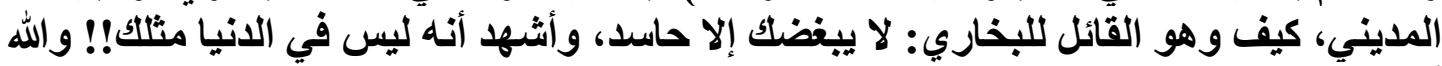
أعلم(r)

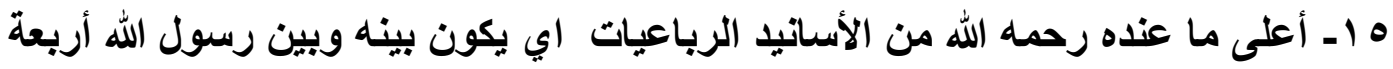

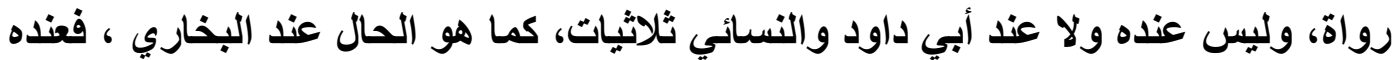
أحاديث ثلاثية كثيرة، وعند الترمذي حديث واحد، وعند وعند ابن ماجه خمسة أحاديث إلا أنها

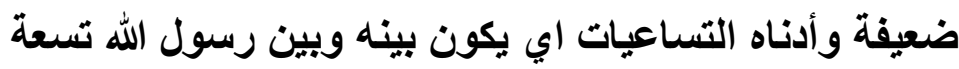
قال السخاوي: أعلى ما عنده الرباعيات ، وأدناه التساعيات .

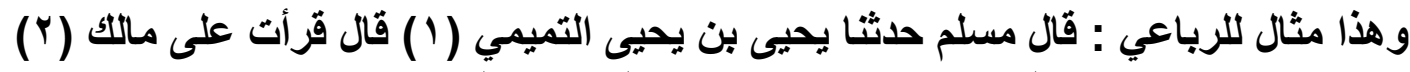

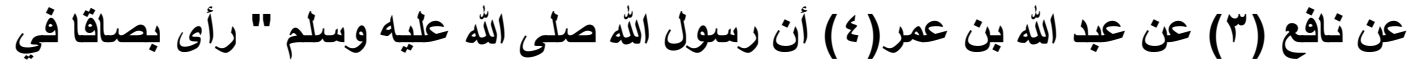

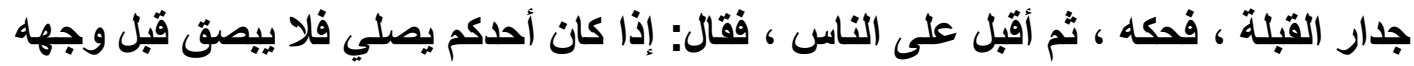

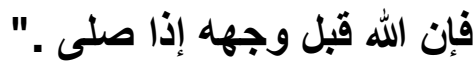

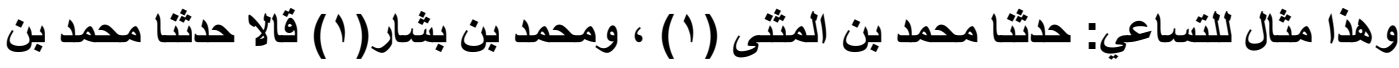

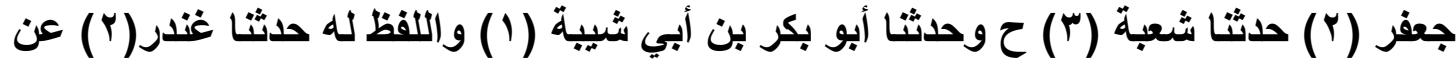

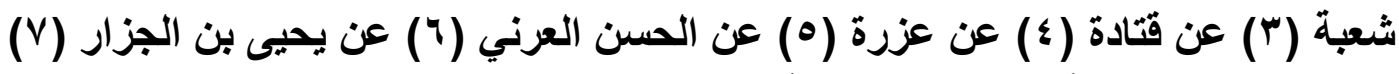

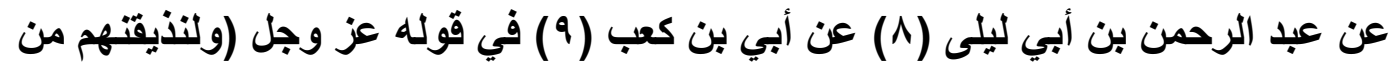

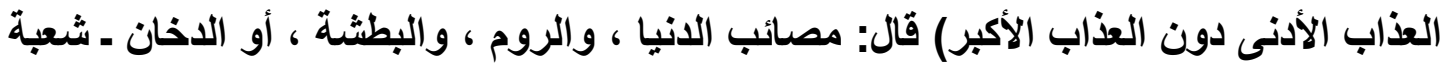

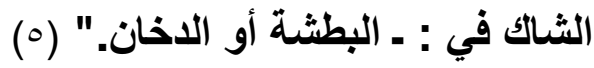

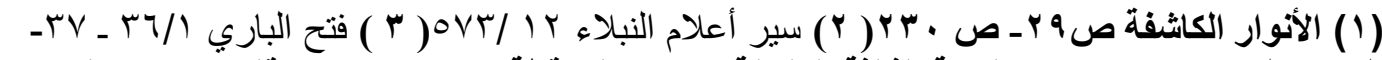

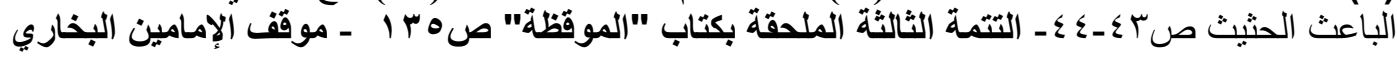

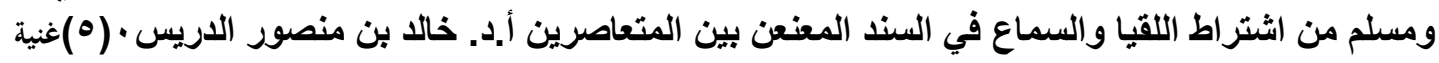




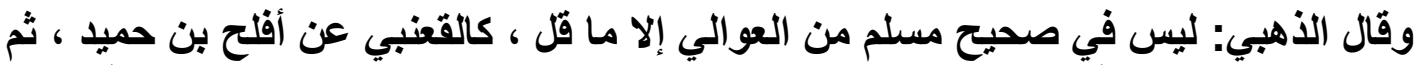

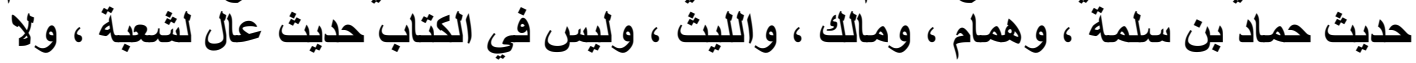

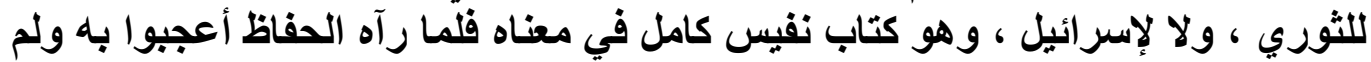

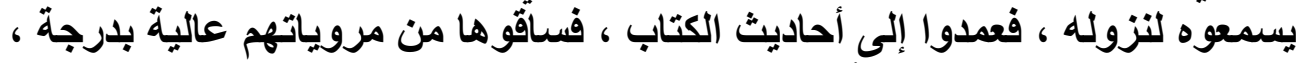

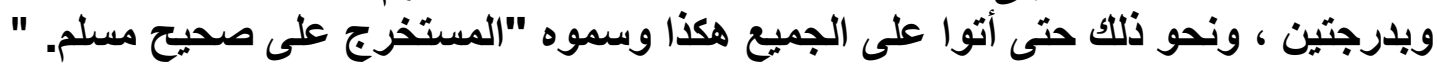

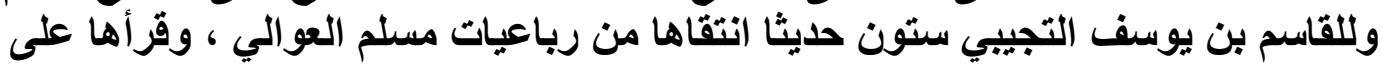

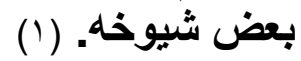

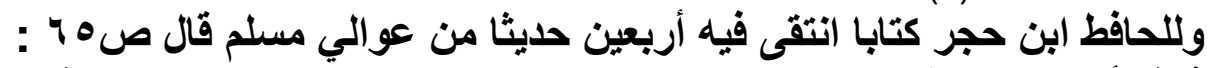

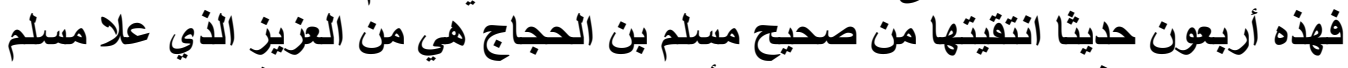

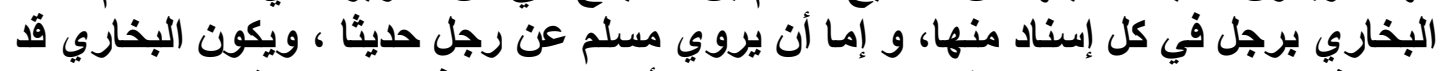

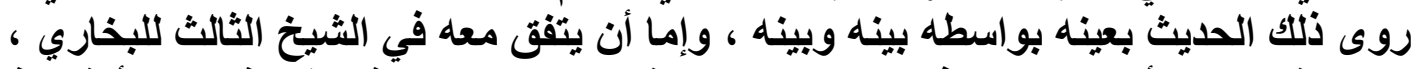

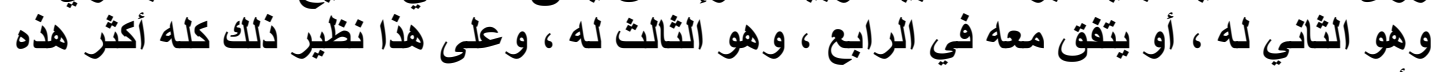

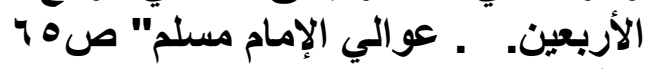
وطبع الكتاب باسم "عو الي الإمام مسلم" صلم وحققه محمد المجذوب ، وطبع باسم "عو الي مسلم

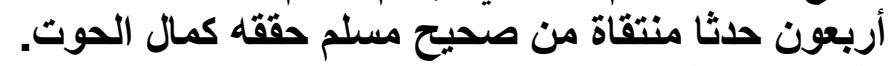

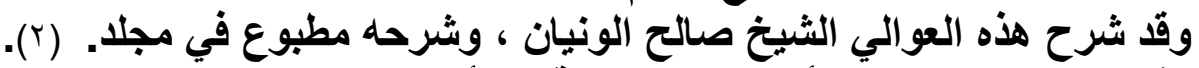

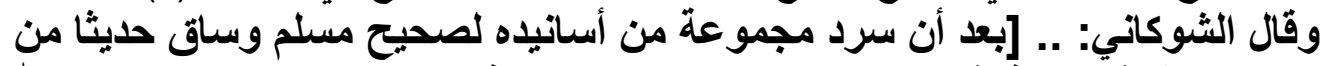

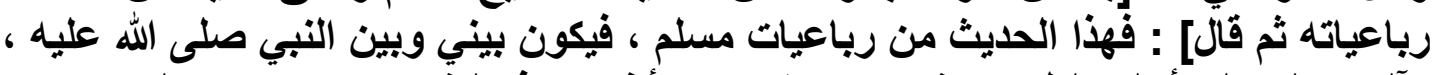

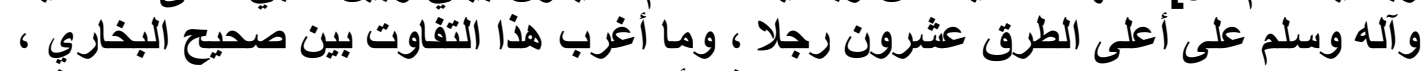

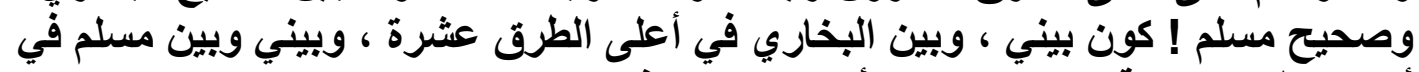

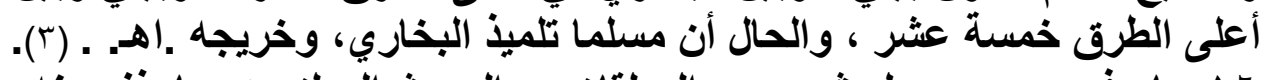

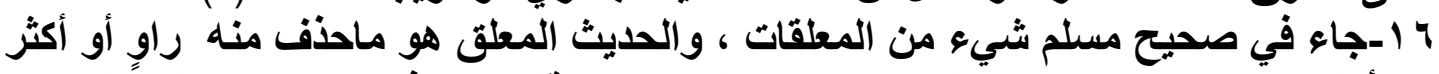

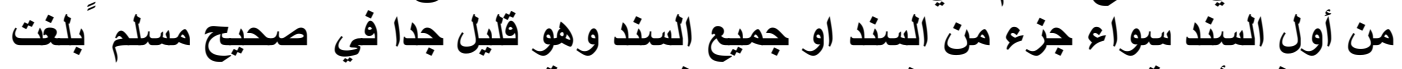

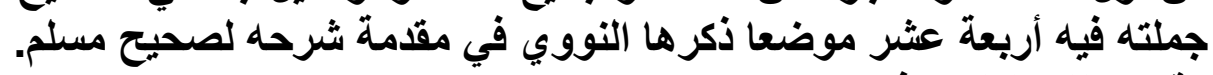

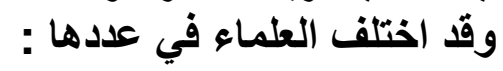
فقال أبو علي الجياني: إنها أربعة عثر موضعاً ، وتابعه المازري ، والعراقي وغيرهم. (ع). وقال ابن الصلاح في صيانة مسلم: -بعد أن ذكر المواضع المعلقة - وذذكر أبو علي الجياني

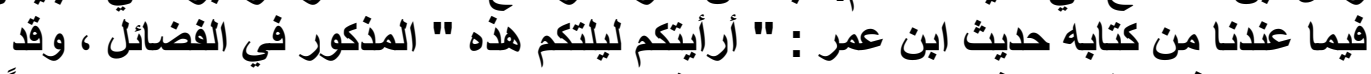

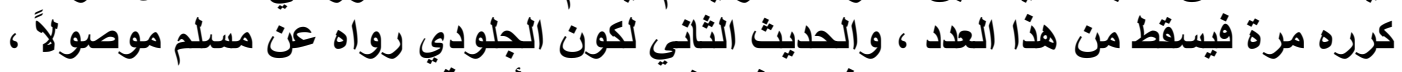

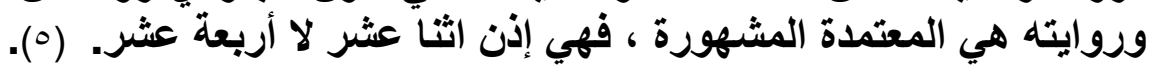

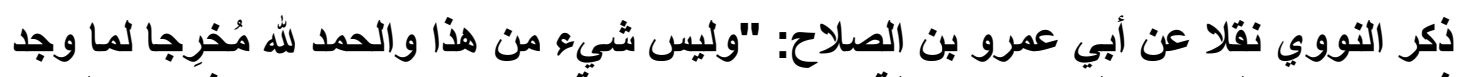

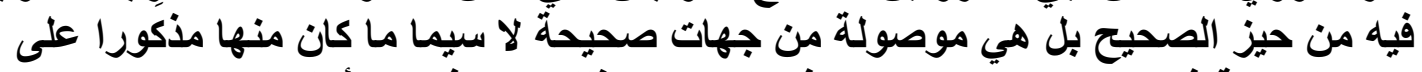

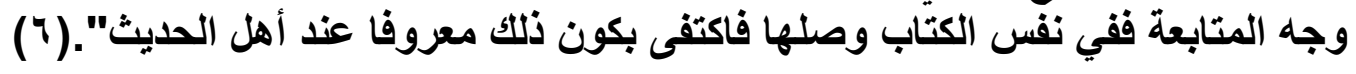

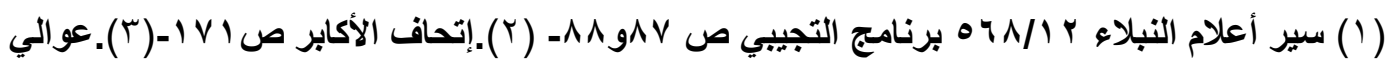

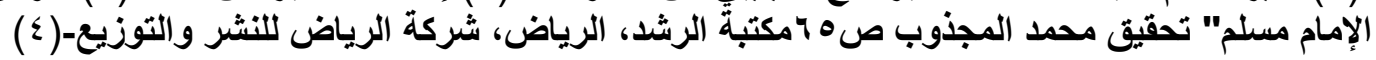

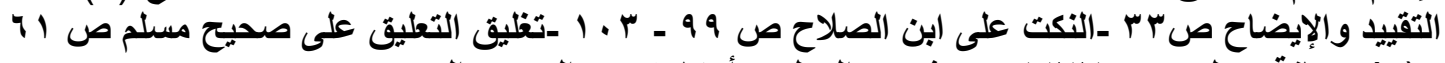

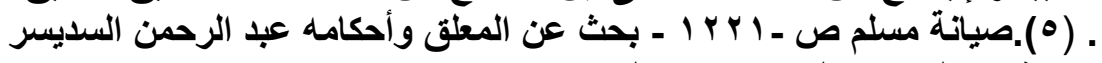

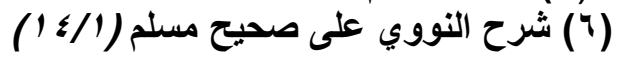


وقال ابن حجر في النكت : بعد أن ذكر المعلقات في صحيح مسلم - : وقد عثرث على شيع إنهاء

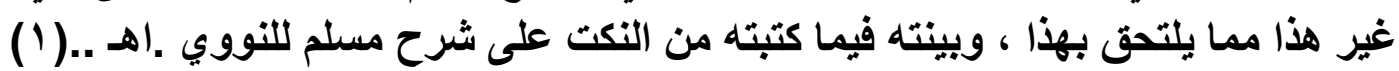

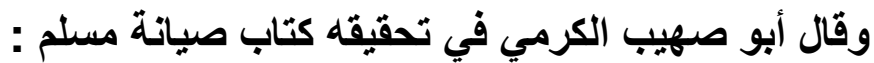

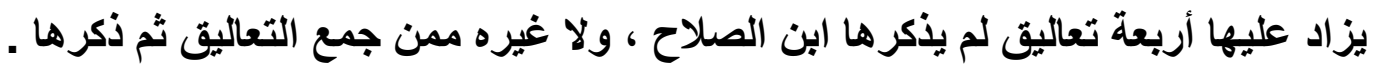

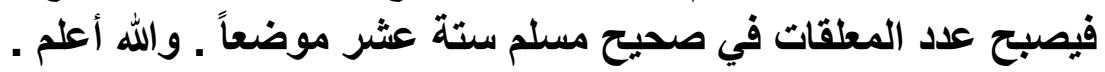
وهذه أنواعها ، ومواضعها :

-1ما علقه ووصله في صحيحه، وهو خمسة أحاديث:

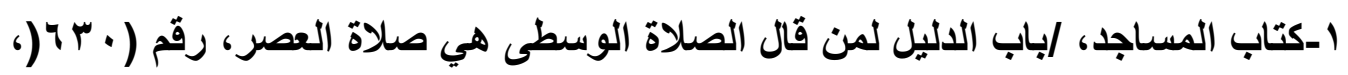

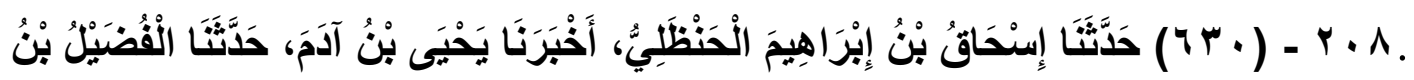

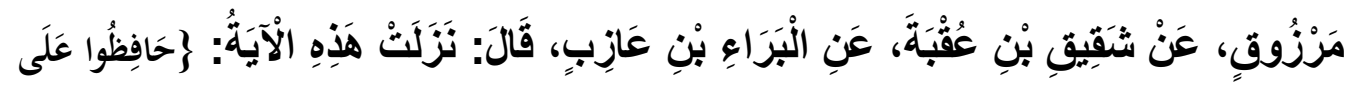

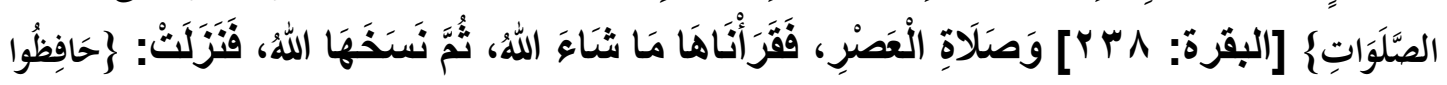

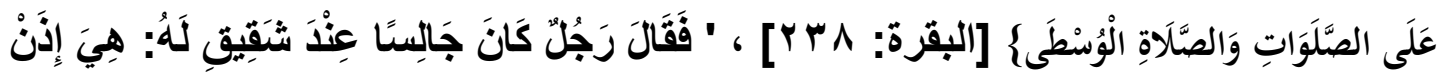

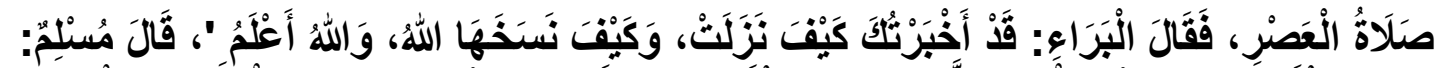

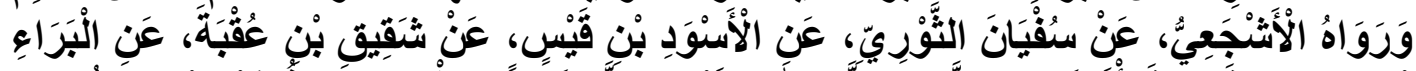

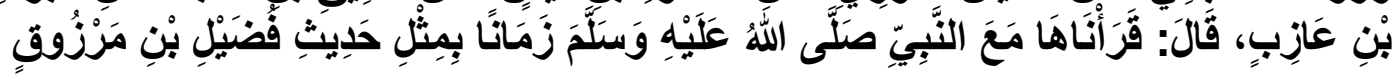

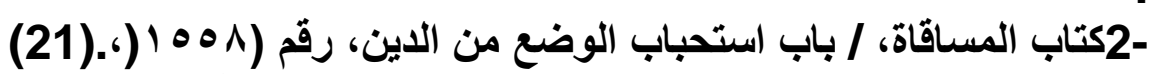

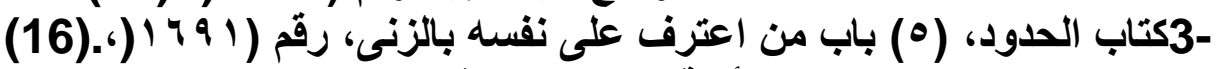

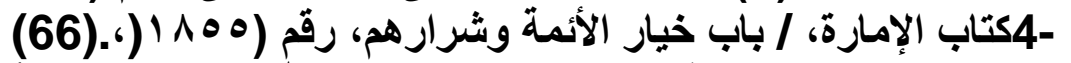

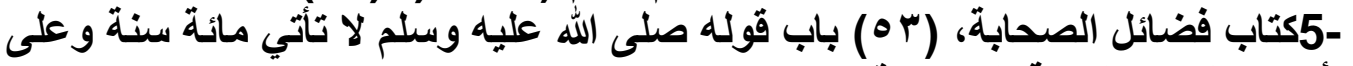

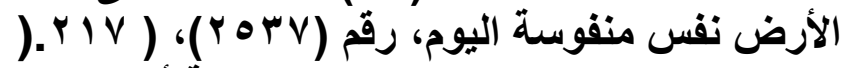

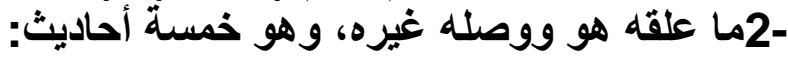

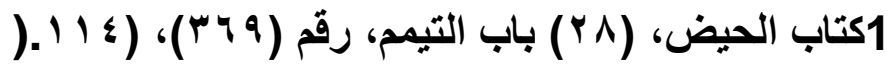

باب التيمم في الحضر لرد السلام

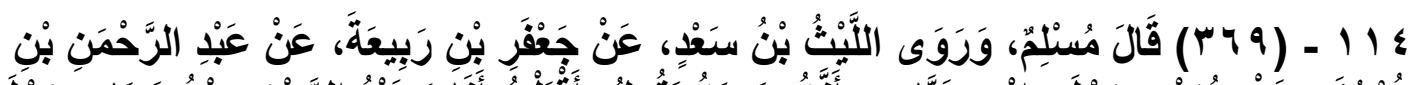

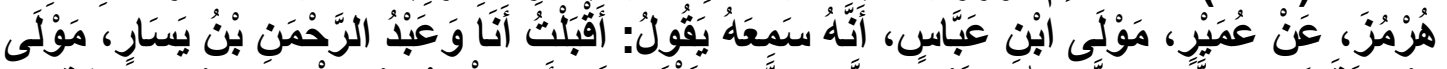

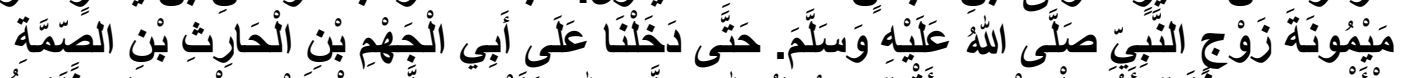

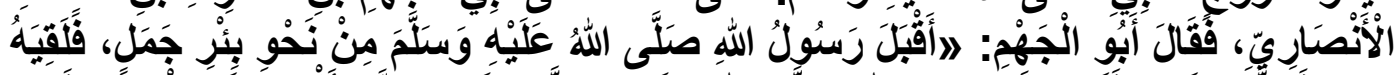

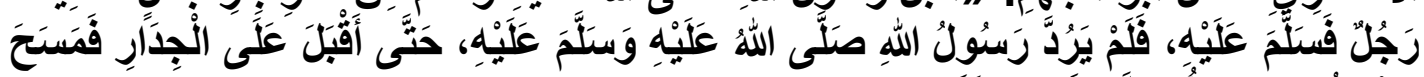

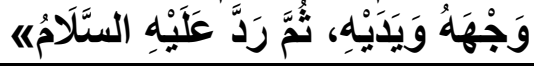

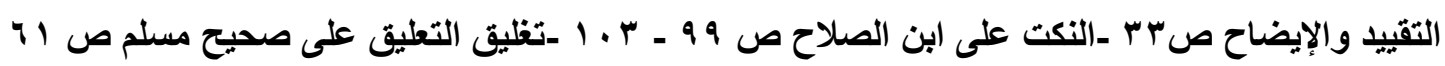

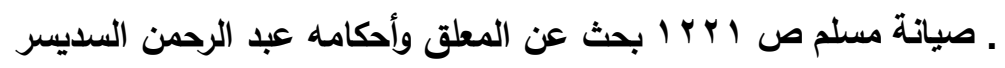




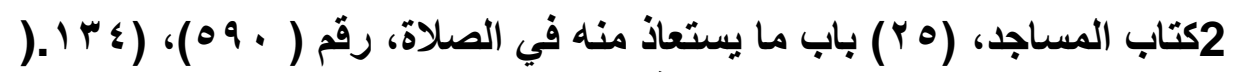

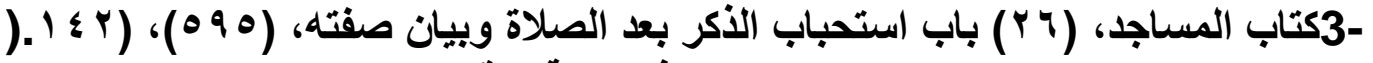

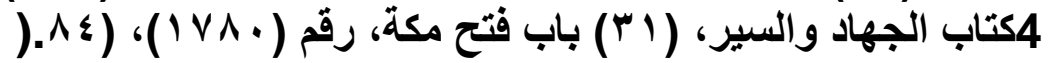

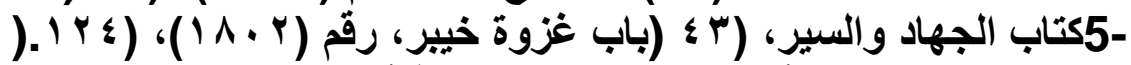

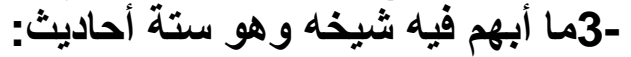

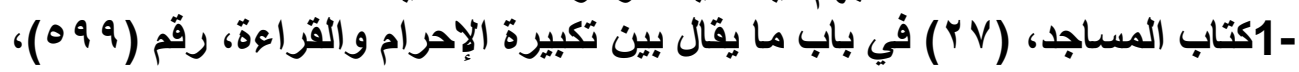
). $1 \leqslant \Lambda$ )

باب إذا نهض من الركعة الثانية

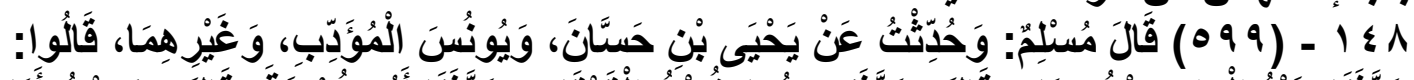

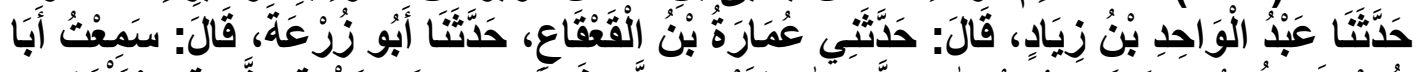

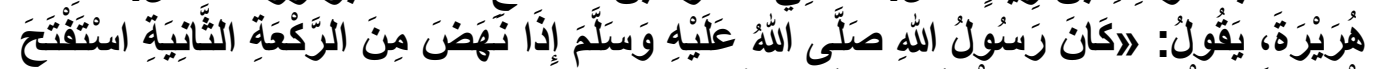

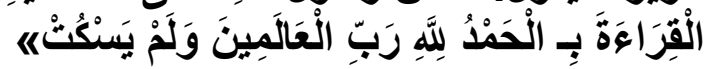

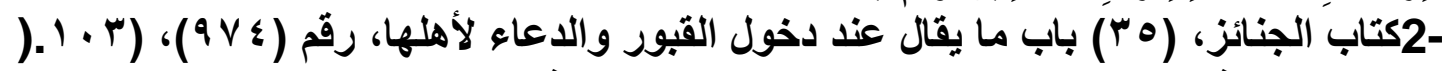

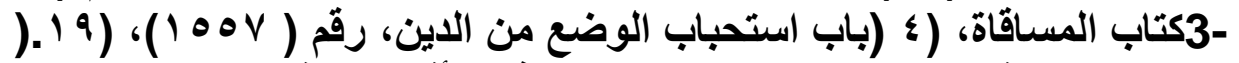

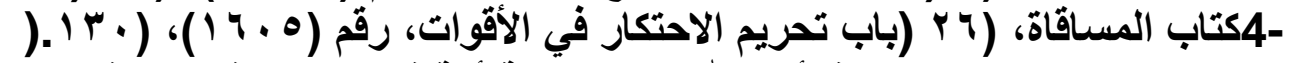

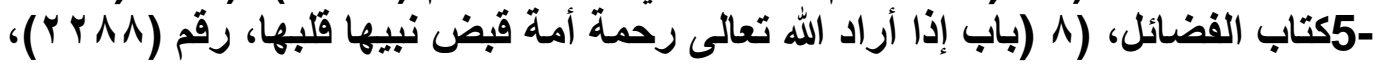

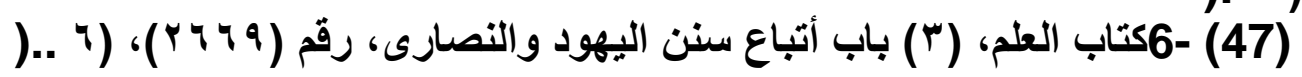

الغرض من ايراد الاحاديث المعلقة:

هذا النوع لم يأتي في الصحيح لغرض الاحتجاج ، و العمل ، بل لأغراض أخرى مختلفة منها : بيان العلة أحيانا ، أو الاستثنهاد ، أو المتابعات .. الخ ـالتعريف بالإمام مسلم ، وكتابه الصحيح : منهجه ، V V ايوجد نحو 17 V أحاديث موقوفة ، ومقطوعة في صحيح مسلم وقع أكثرها ضمن أحاديث

مرفوعة (1) ماندو

الأحاديث الموقوفة هي المروية عن الصحابة مع الوقوف عليه وعدم وصل السند الى التبي

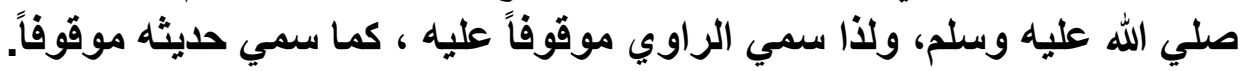

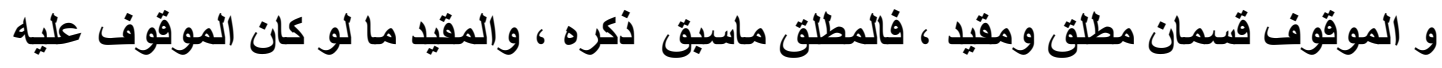

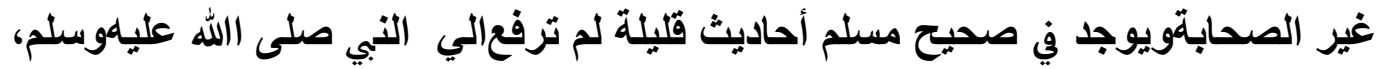
وهي إما موقوفة على بعض الصحابة، أو مقطوعة من أقوال التابعين و معظمهذه الأحاديث

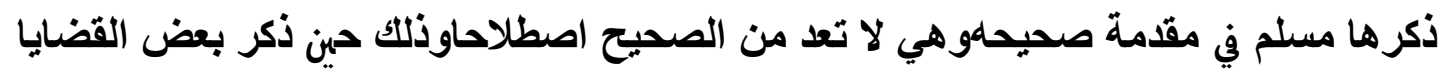

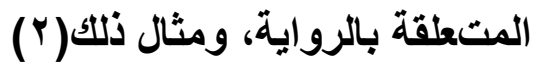




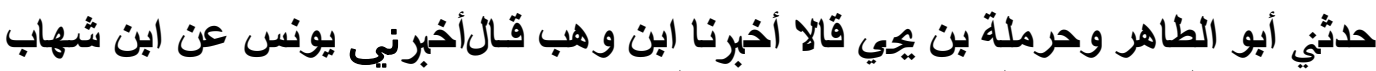

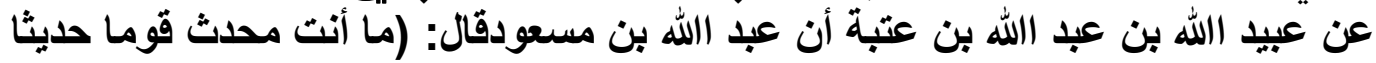

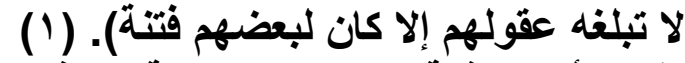

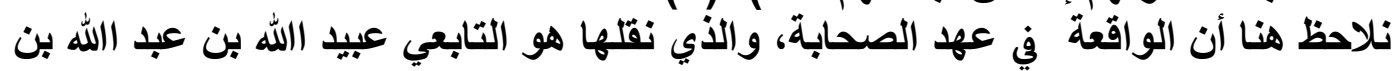

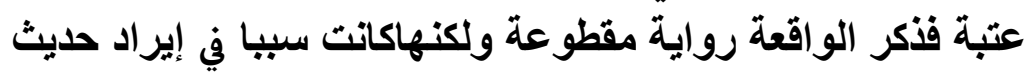

وخلاصة القول فإن هذا النوع من الروايات قليل جذا عند مسلم، قد وقع أكثرها ضمن

أحاديث مرفوعة.

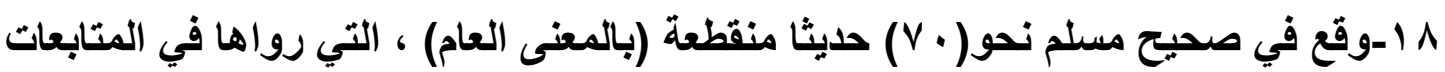

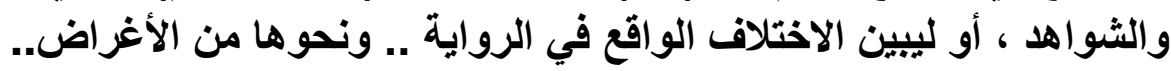

وهذه ليست من مقصود الصحيح ..

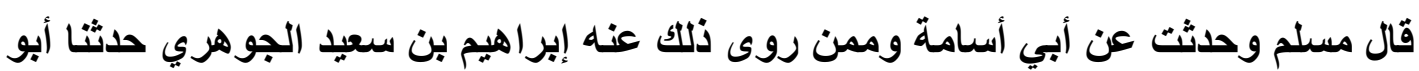

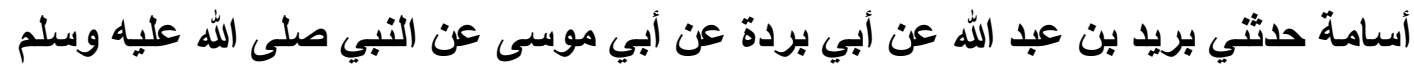

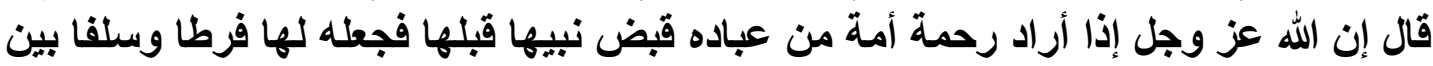

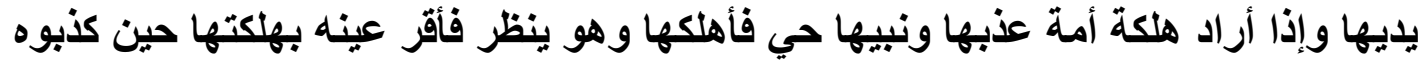

و وعصوا أمره (r)

قال المازري والقاضي : هذا الحديث من الأحاديث المنقطعة في مسلم ، فإنه لم يسم الذي حدثه عن أبي أسامة .

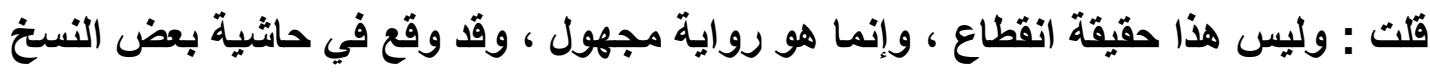

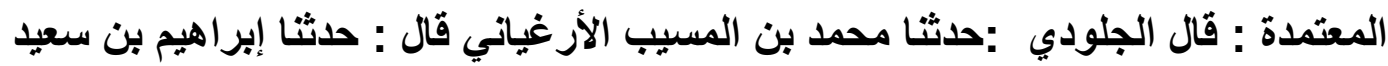
الجوهري بهذا الحديث عن أبي أسامة بإسناده

9 ا -وقع في صحيح مسلم نحو( • V ) حديثا منقطعة (بالمعنى العام) ، التي رواها في المتابعات

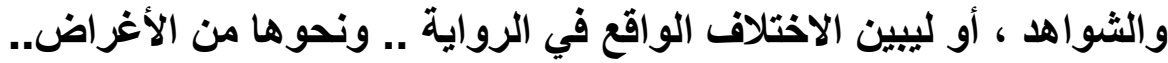

ورذه ليست من مقصود الصحيح(3).

(1) (1) (بواه مسلم في مقدمة الصحيح

(Y)شرح النووي على مسلم/ كتاب الفضائل/ باب إذا أراد الله تعالى رحمة أمة قبض نبيها قبلها

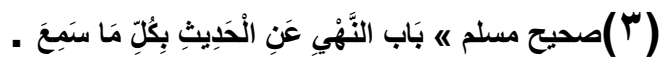


المطلب الرابع بحوث ودراسات حول الصحيح:

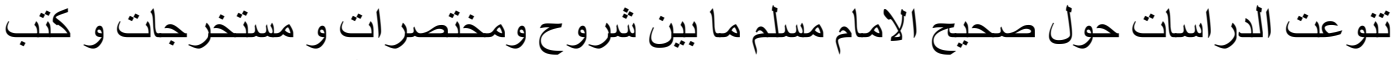

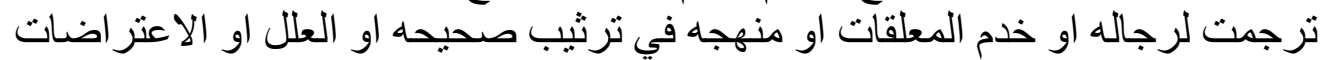

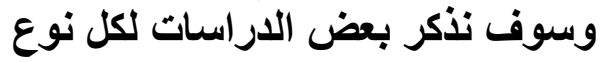

اولا:شروح صحيح الإمام مسلم: (1)

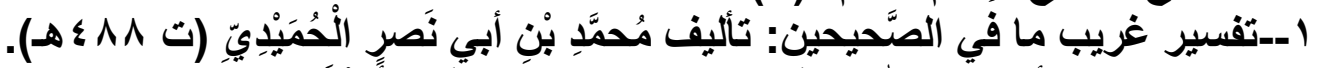

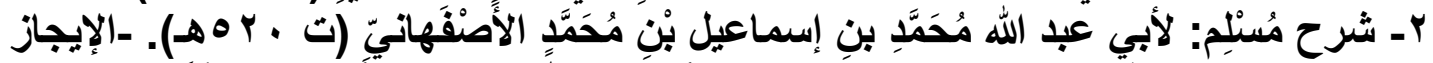

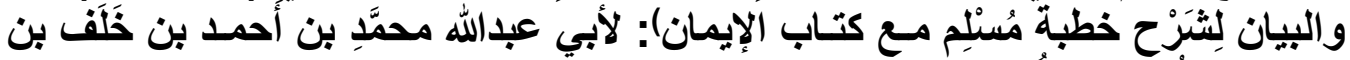

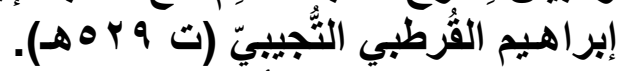

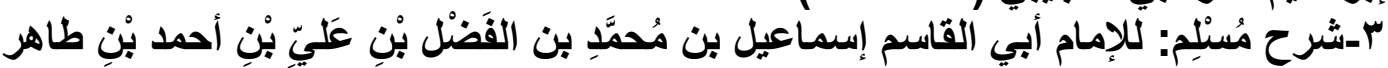

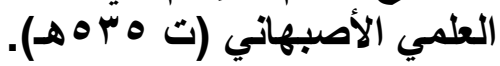

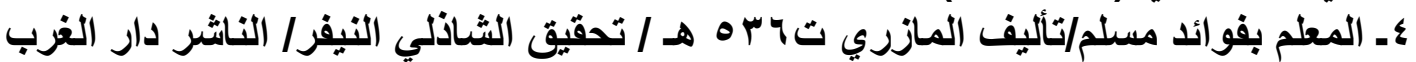

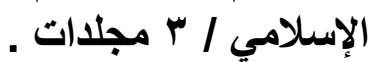

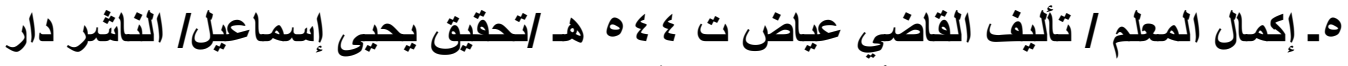
الوفاء / في 9 مجلات وطم اتبع أيضا في مطبعة السعادة ومعه مكمل إكمال الإكمال.

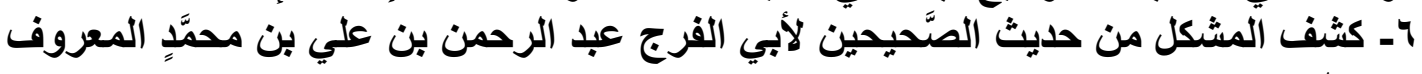

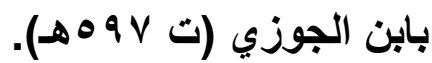

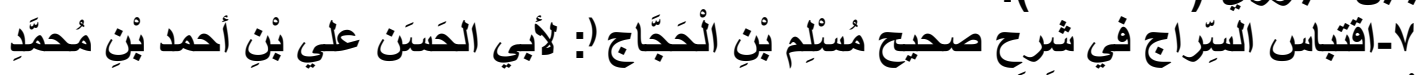

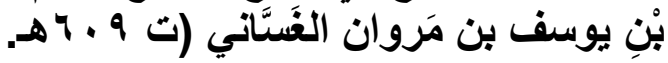

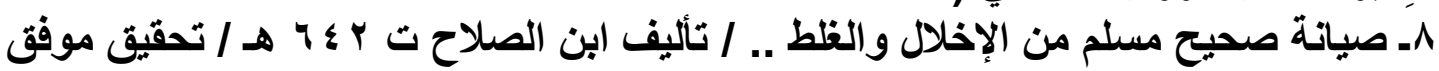

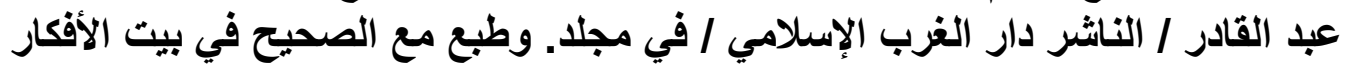
الاولية. وهو شرح لكتاب الإيمان من صحيح مسلم.

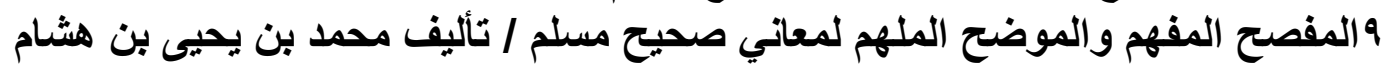

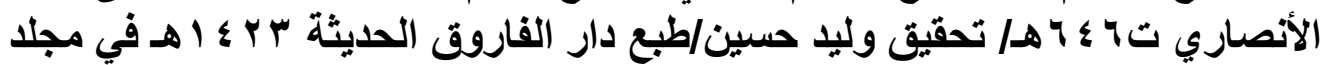

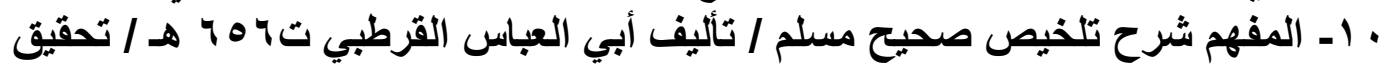

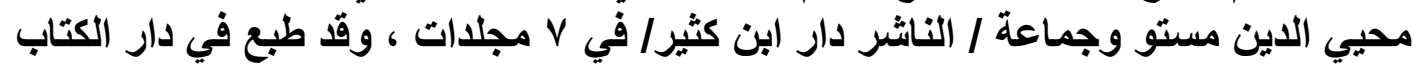

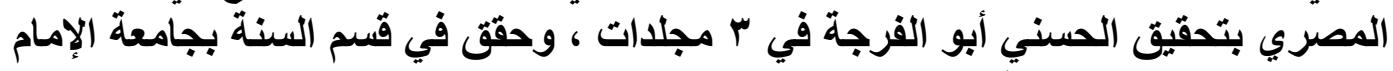

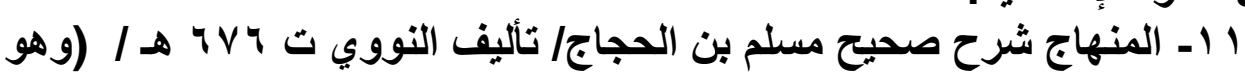
محمد بن سعود الإسلامية. شرح وسط مفيد جمع عدة شروح سبقته، ومن أشهر شروح صحيح مسلم طبع عدة طبعات

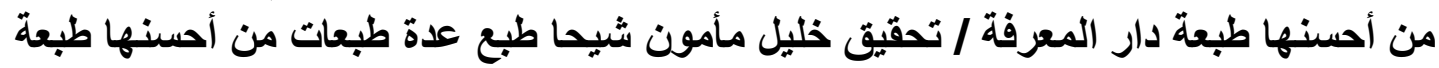

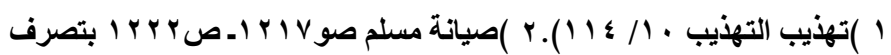

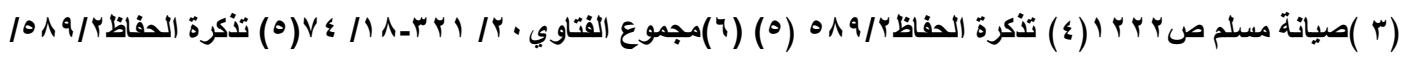

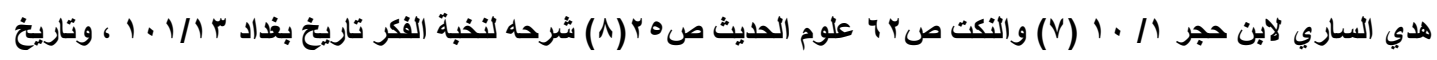
دمشث 9 r/01

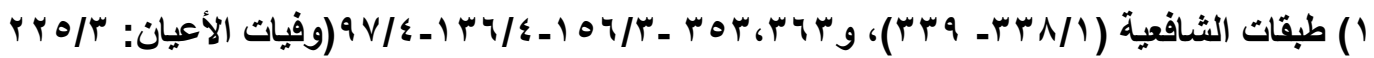

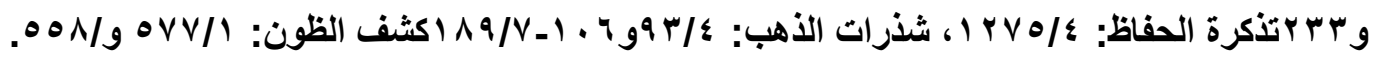

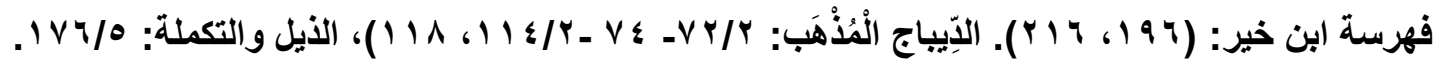




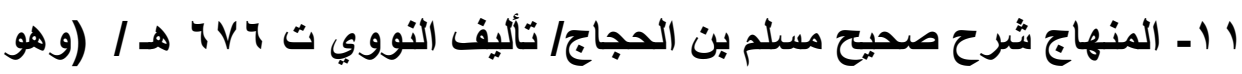
شرح وسط مفيد جمع عدة شروح سبقته، ومن أشهر شروح صحيح مسلم طبع عدة طبعات

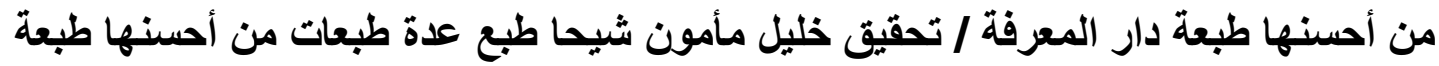

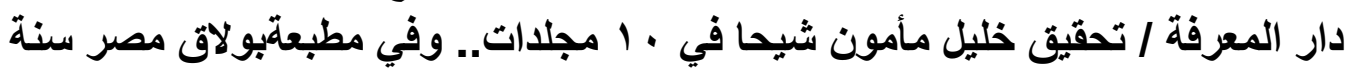

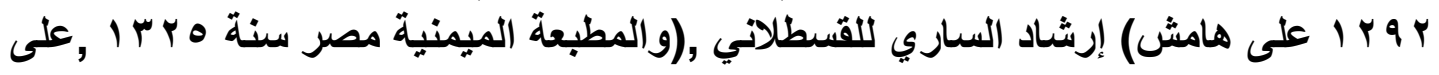

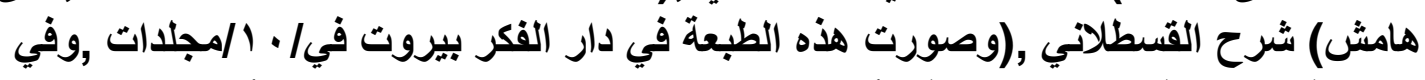

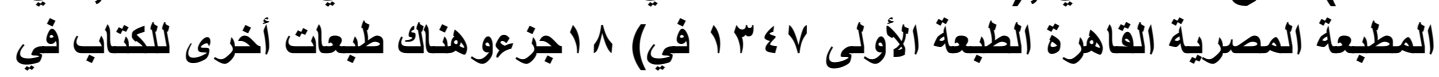

دار الفكر

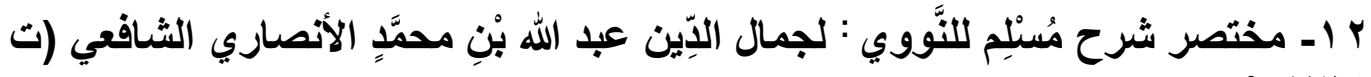
. A P Y (

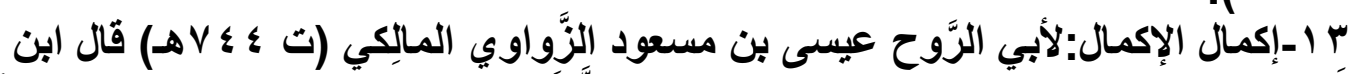

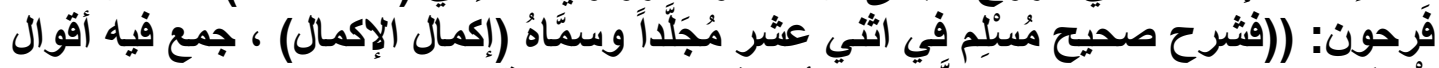

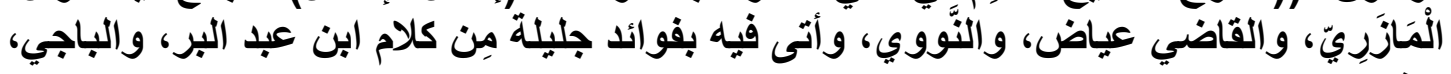
وغيرهما.

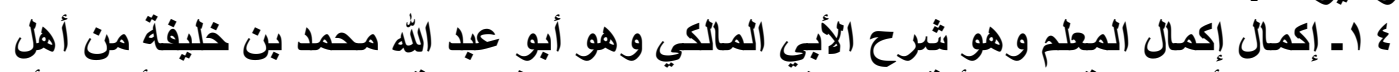

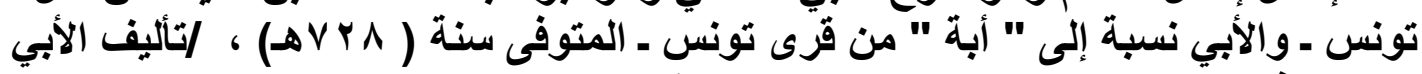

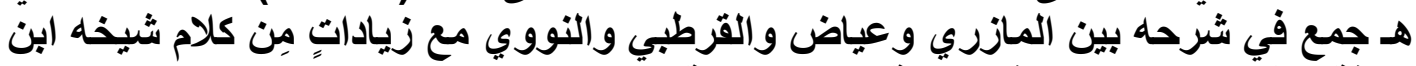

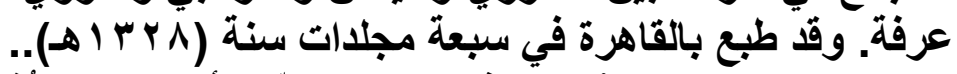

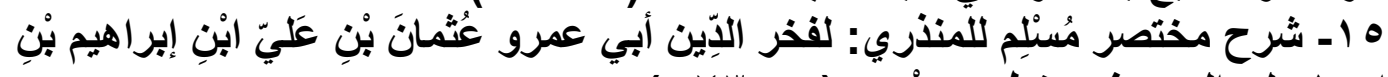

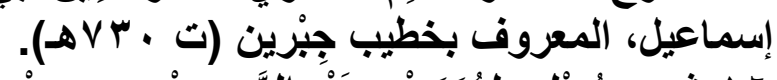

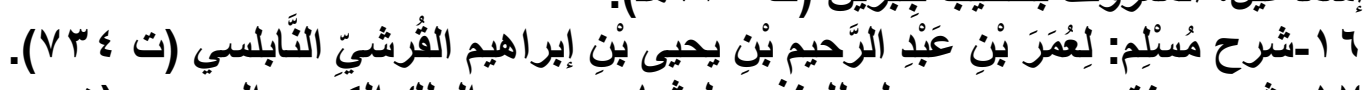

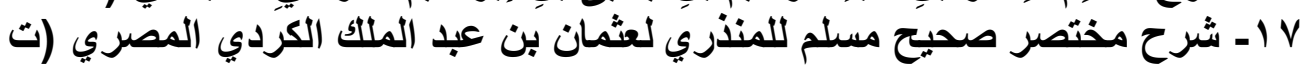
(هVM

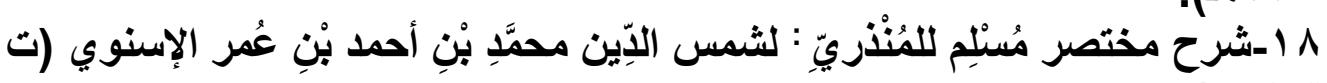
.

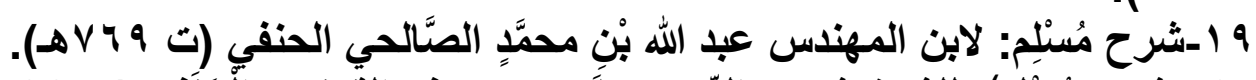

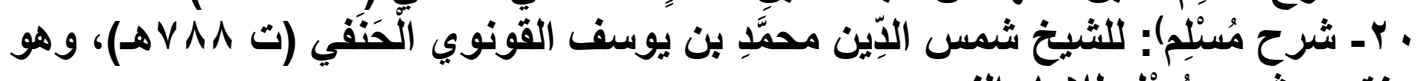

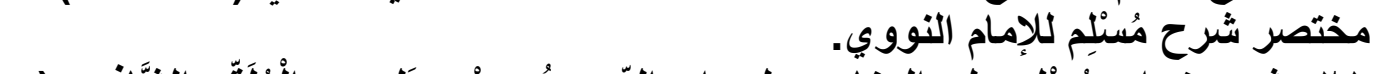

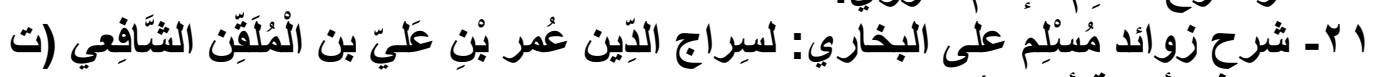

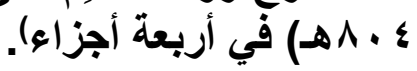

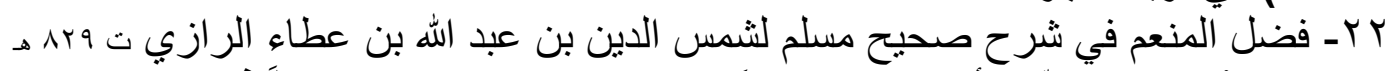

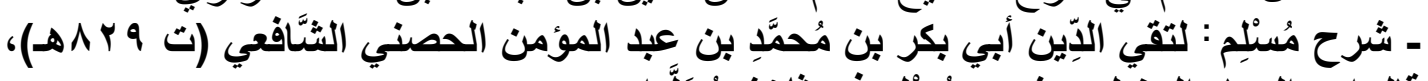

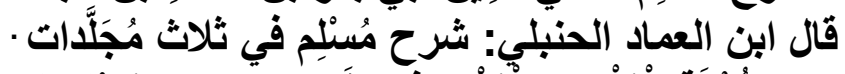

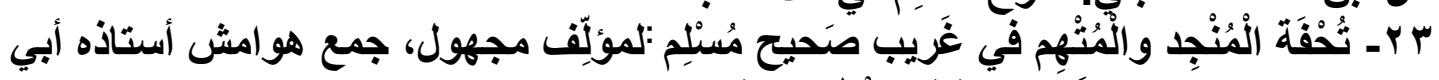

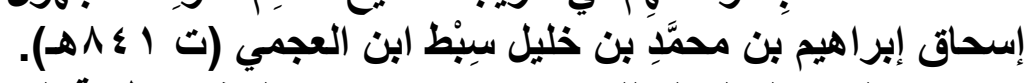

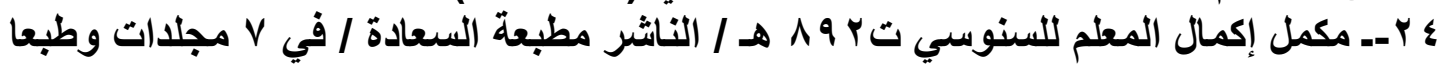
أيضا في دار الكتب العلمية في 9 مجلدات .

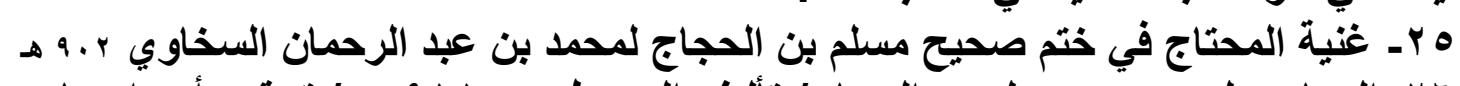

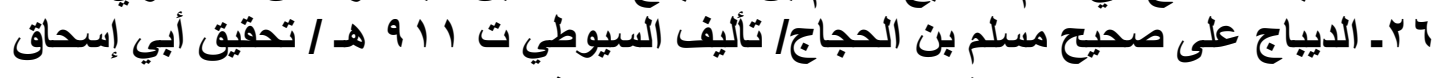

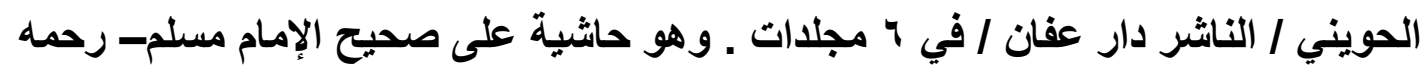




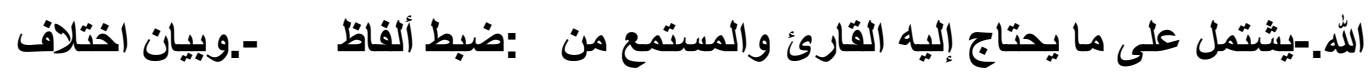

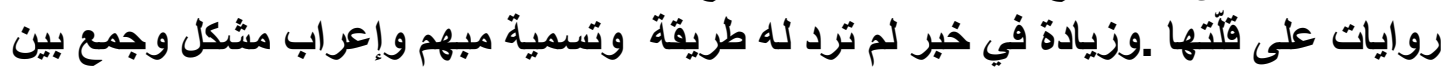

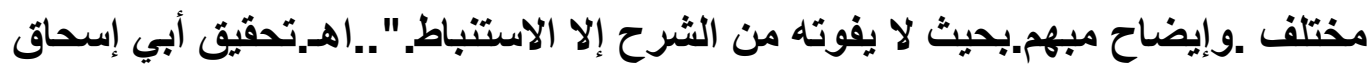
الحويني / الناشر دار عفان.

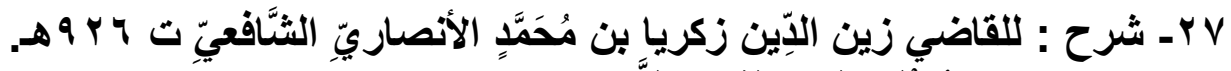

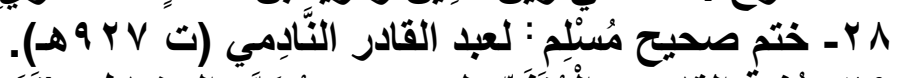

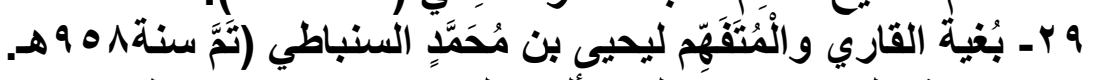

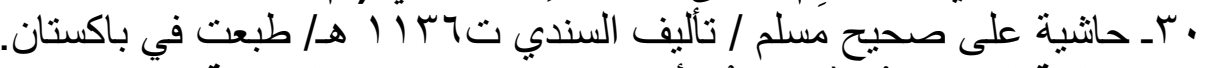

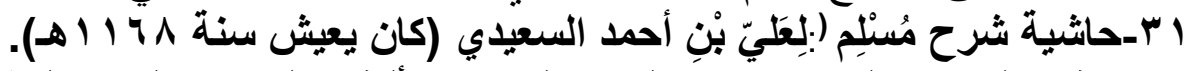

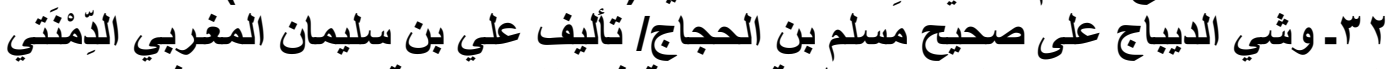

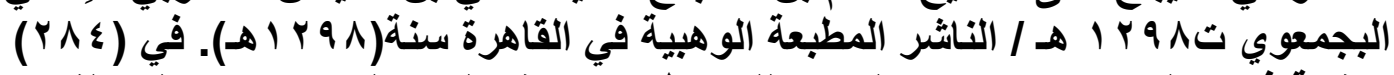

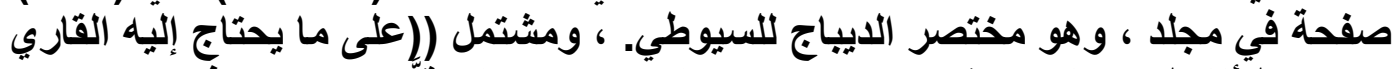

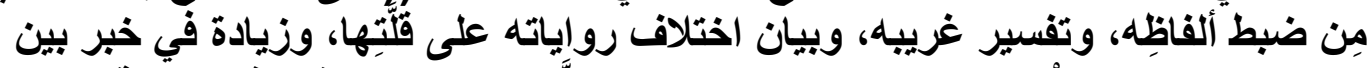

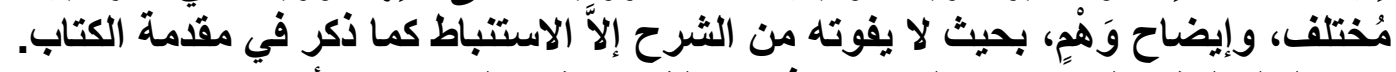

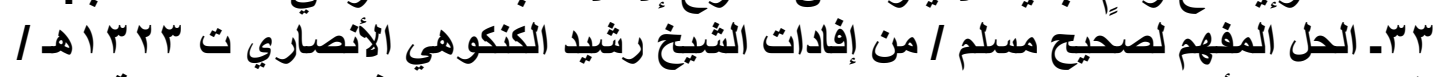

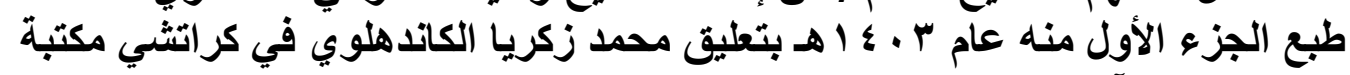
الشيخ- بهادر آباد باكستان.

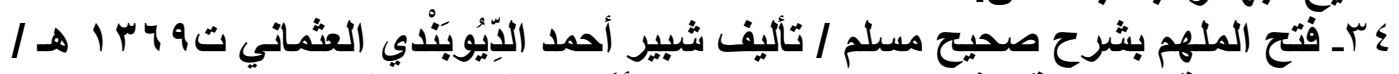

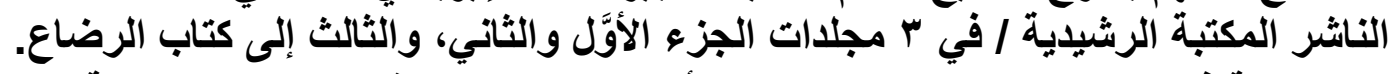

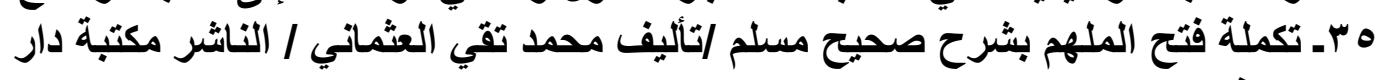

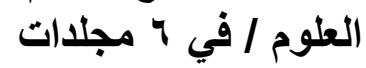

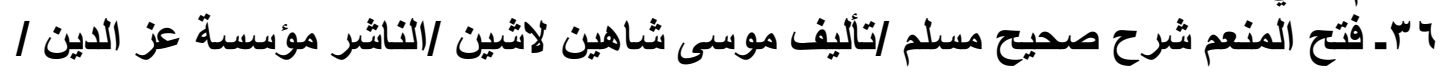

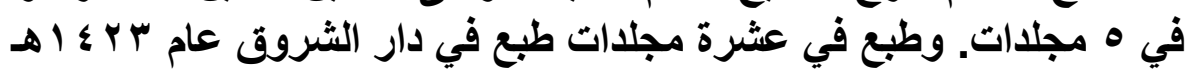

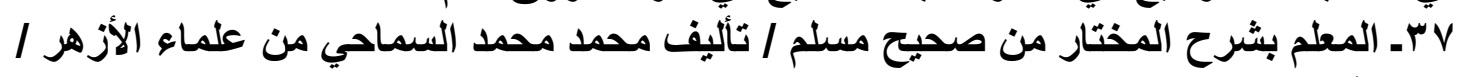

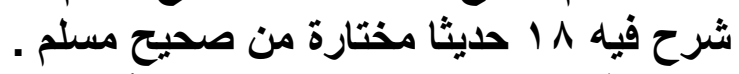

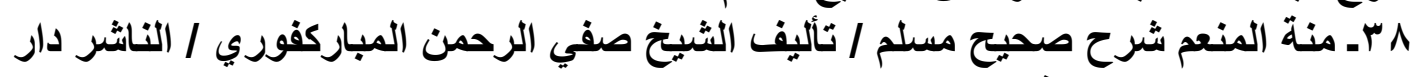

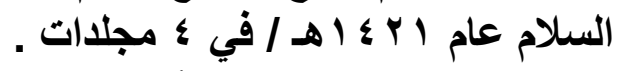

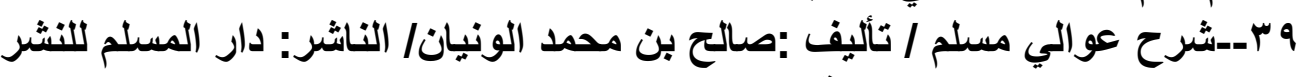
والتوزيع - الرياض ع ع السعودية.

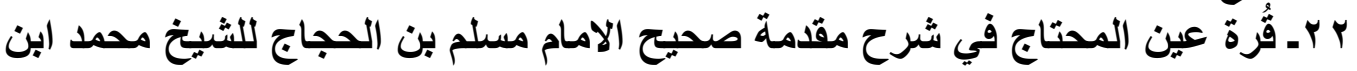

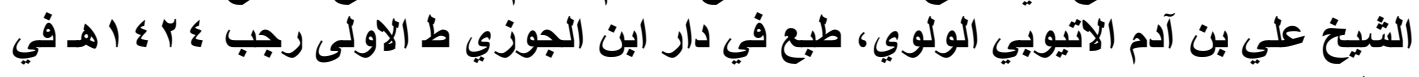
بَّ البحر المحيط الثجاج في شرح صحيح مسلم بن الحجاج ـ للشيخ علي بن آدم بن موسي

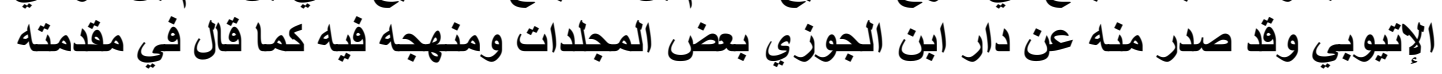

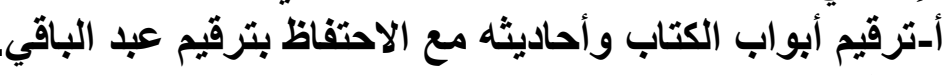

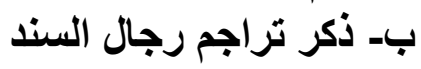

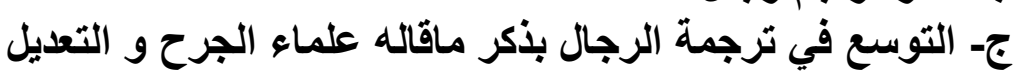

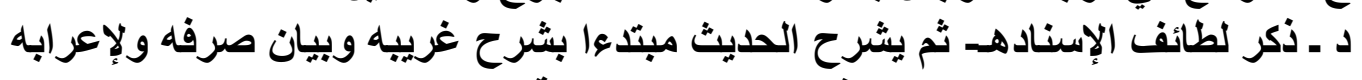

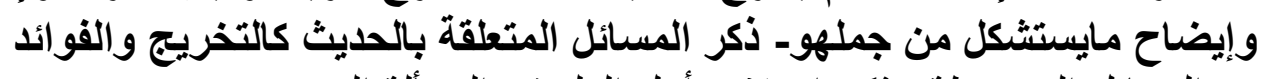

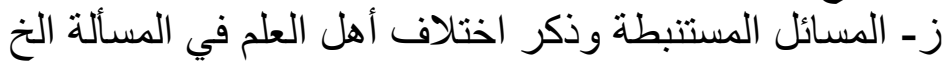


ح- العناية بإتمام إحالات المصنف و هذا البحث مهم جدا فإن إحالات المصنف رحمه الله كثيرة

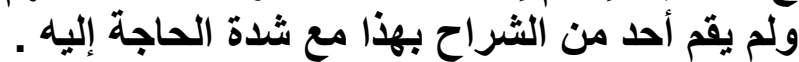

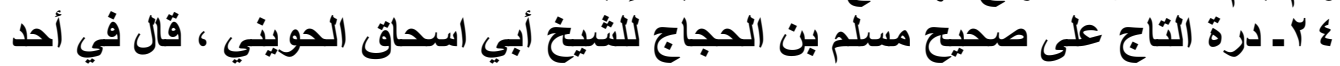

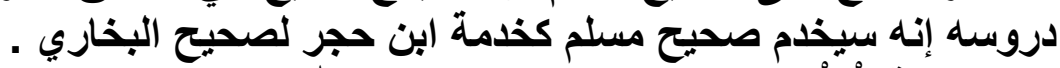

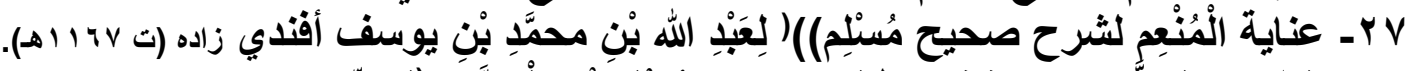

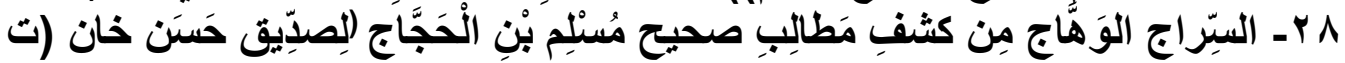

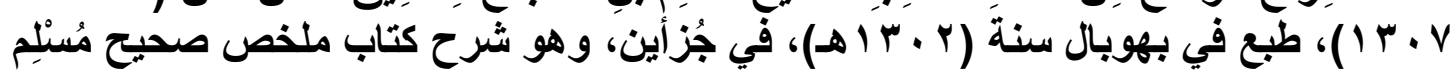

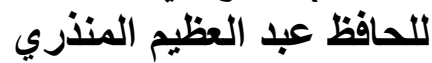

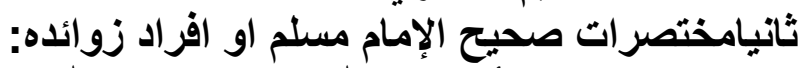

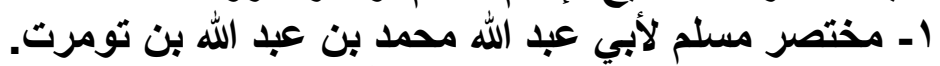

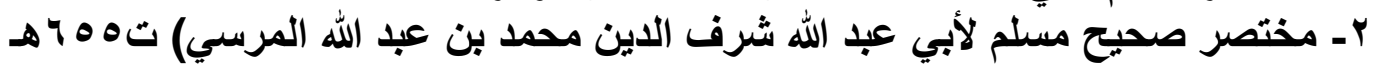

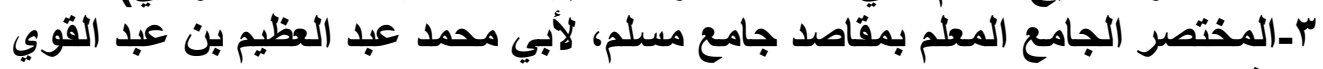

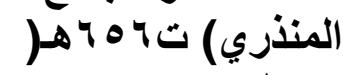
ــ تلخيص صحيح الإمـام مسلم لأبي العباس أحمد بن عمر بن إبراهيم القرطبي

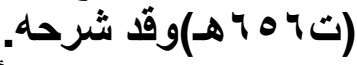
هـ إرشاد الساري إلى أفراد مسلم عن البخاري ، جمع الشيخ عبد الله العبيلان زوائد مسلم

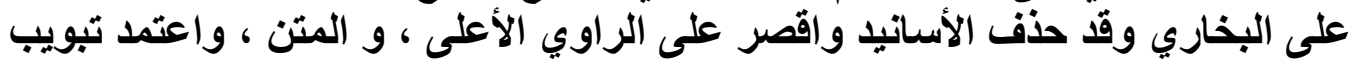

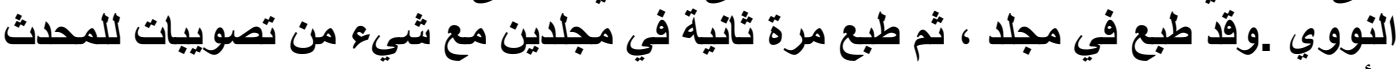
الألباني.. - الأوفي.

ثالثامستخرجات على صحيح الإمام مسلم:

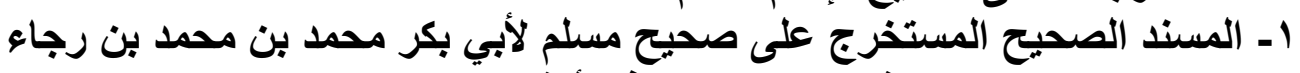

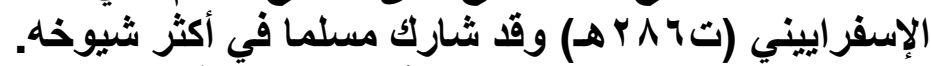

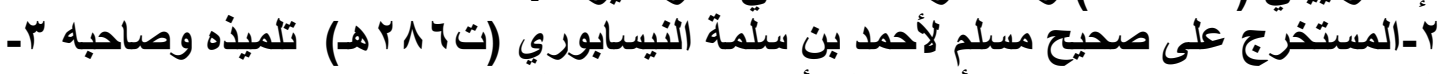

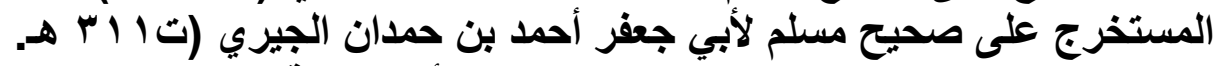

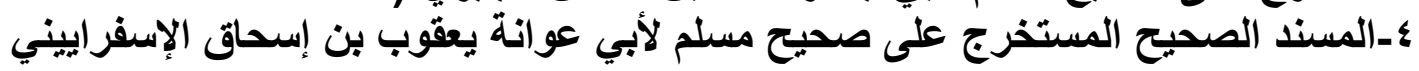

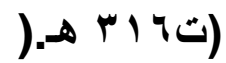

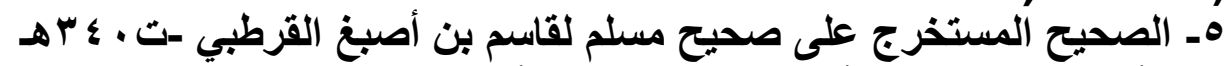

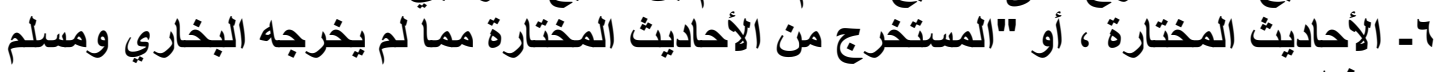
وللحافظ ضياء الاين المقدسي الماري V- مستخرج الحافظ العراقي على مستدرك الحاكم ، وهين ، وهو عبارة عن أحاديث أملاها في

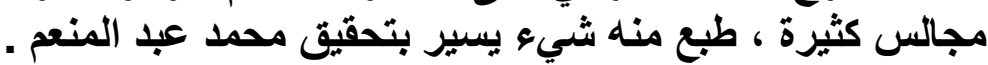

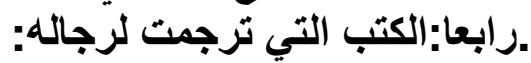

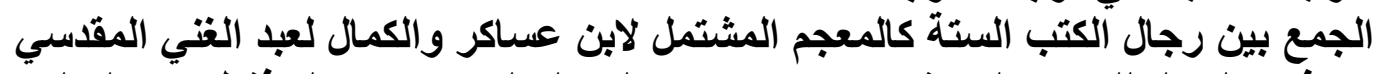

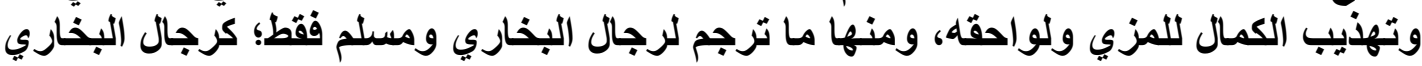

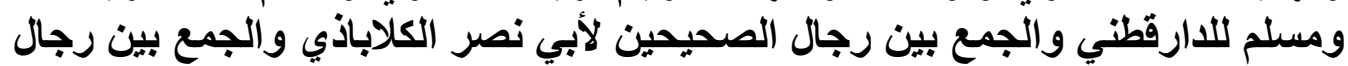

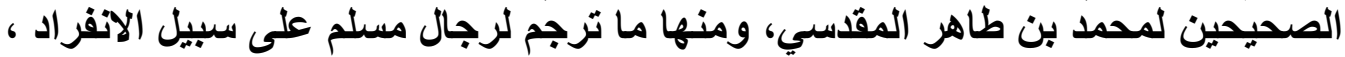

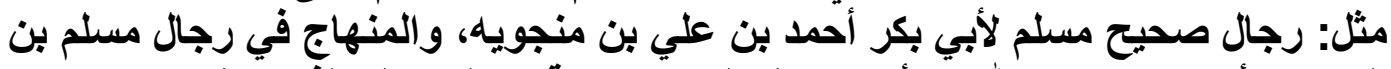

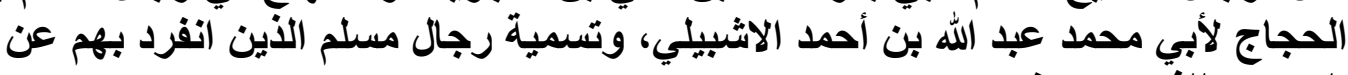

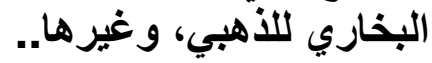


رابعا: كتب تتبعت واستدركت علي الصحيحين والرد عليها:

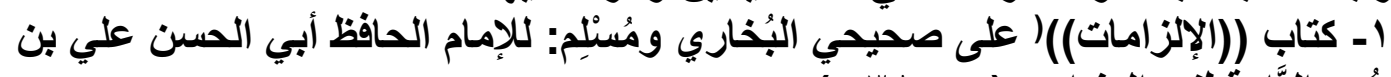

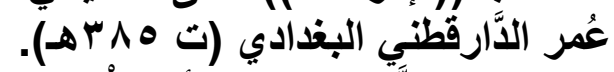

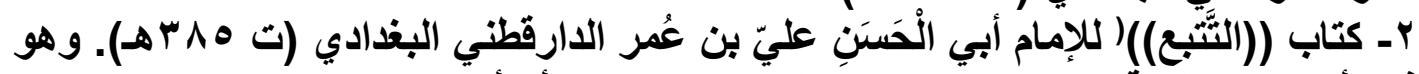

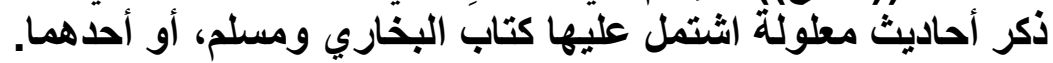

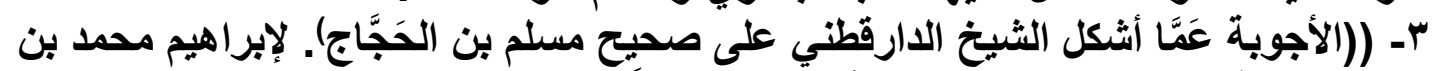

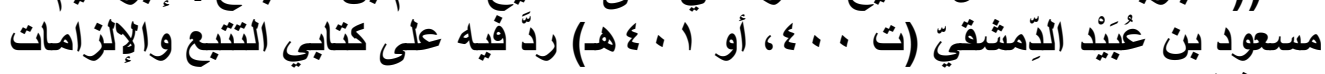

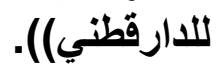

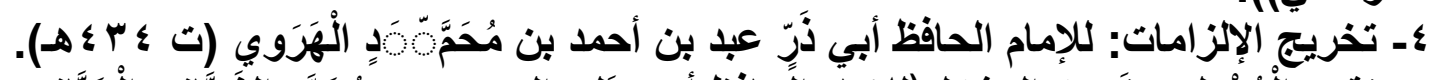

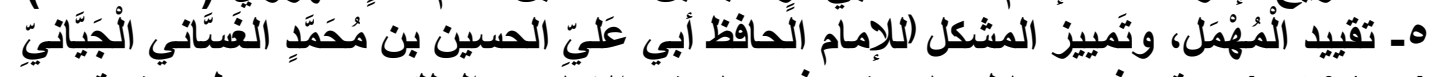

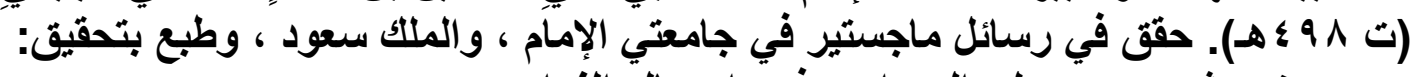

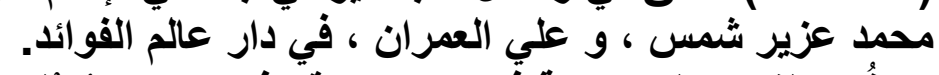

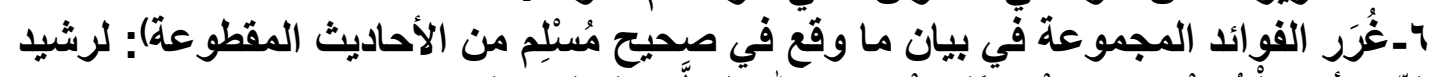

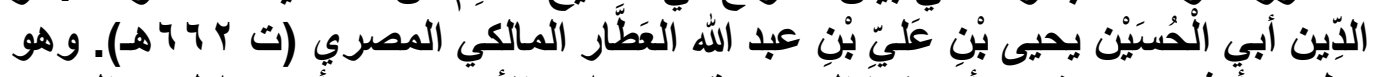

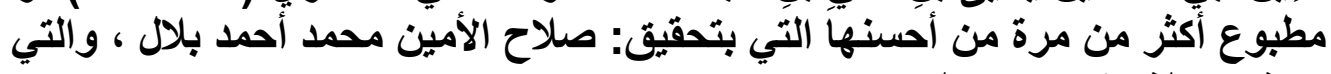

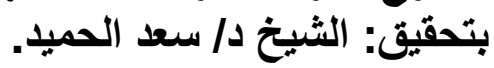

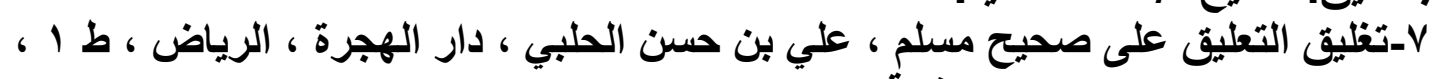

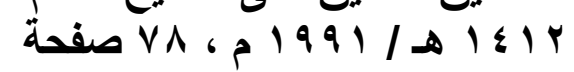

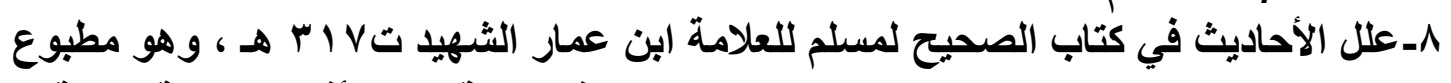

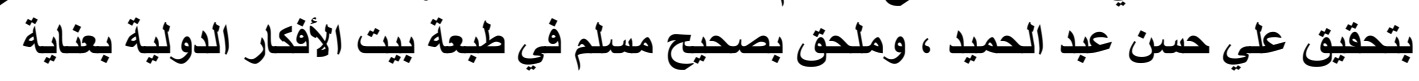
أبي صهيب الكرمي.. 9-كتاب "عبقرية مسلم" نفائس عن منهجه في الترتيب ، والتعليل ؛ للشيخ حمزة المليباري

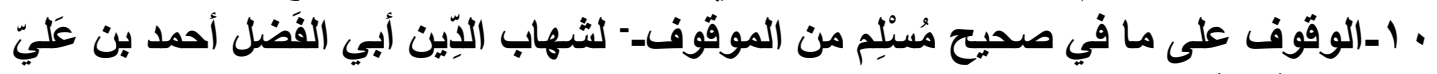

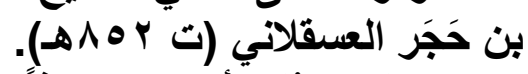

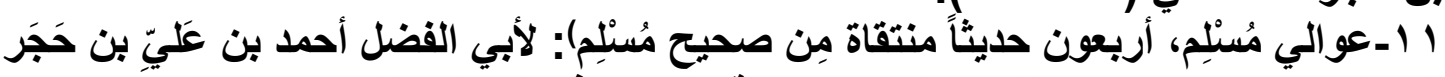

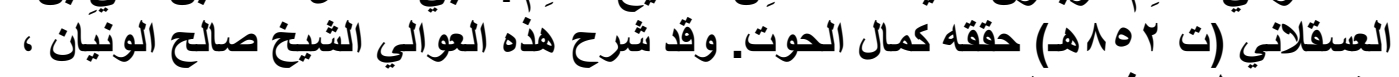

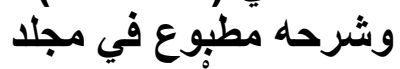

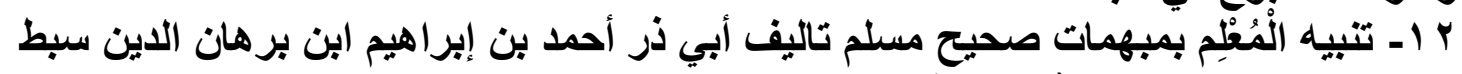

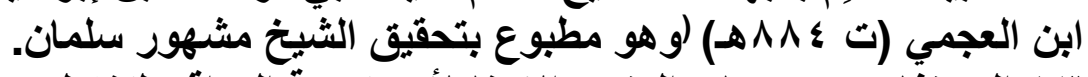

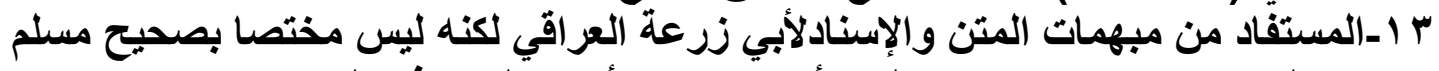

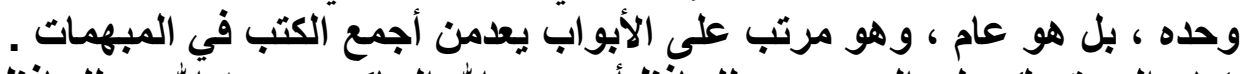

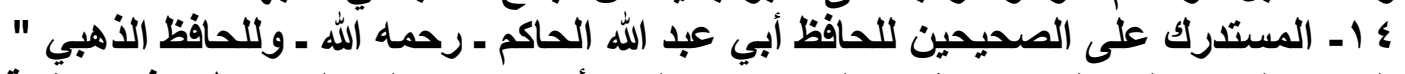

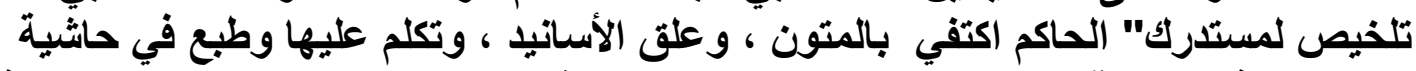

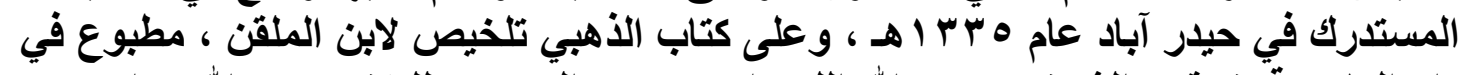

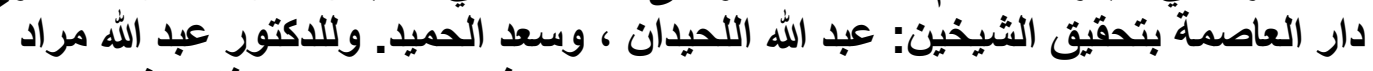

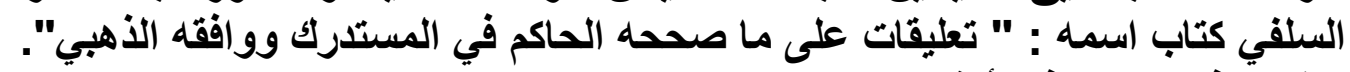

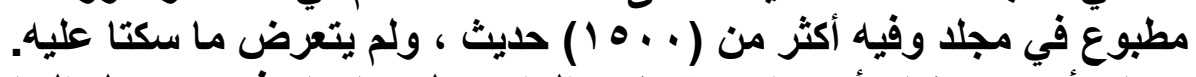

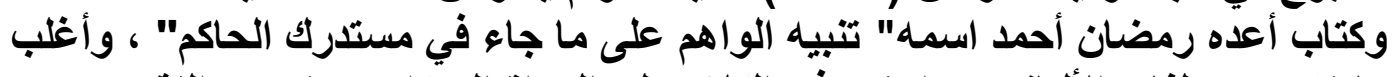

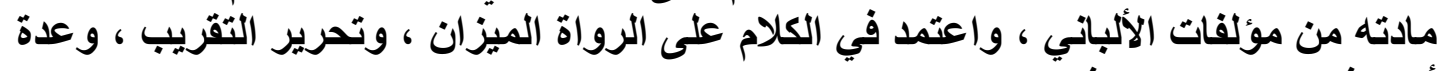

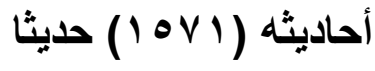


مستخرج الحافظ العراقي على مستدرك الحاكم ، وهو عبارة عن أحاديث أملاها في مجالس

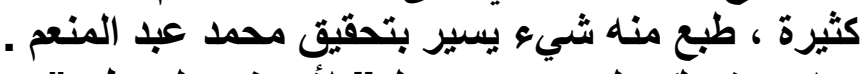

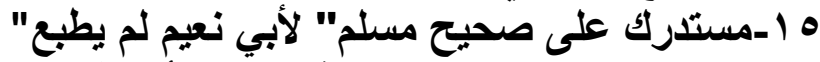

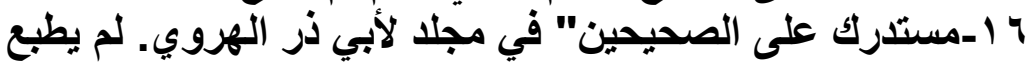

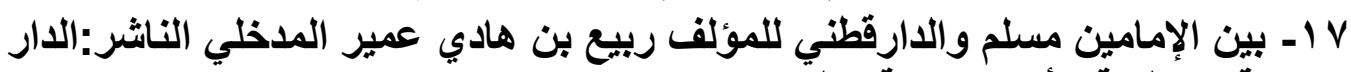

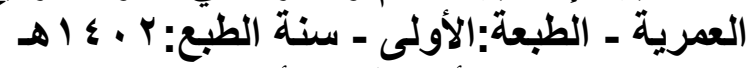

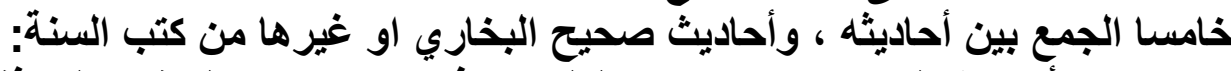

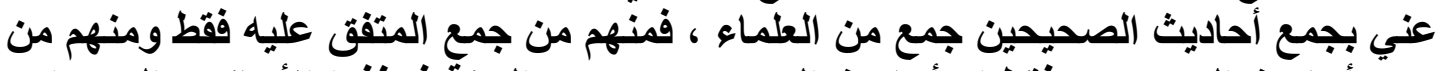

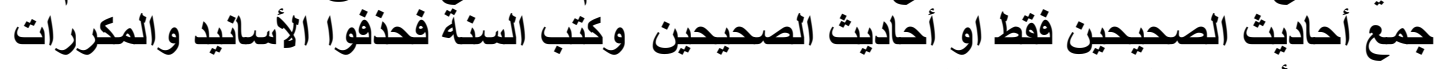

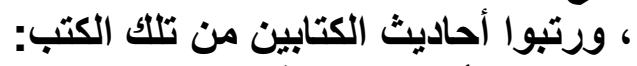

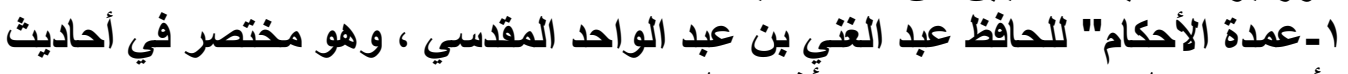

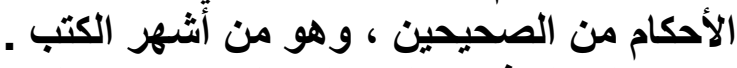

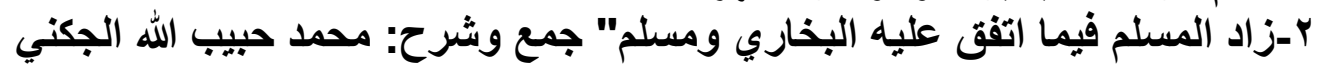

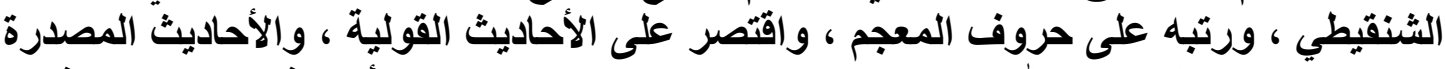

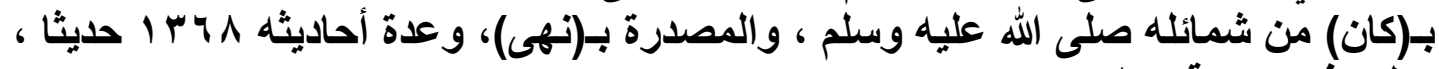

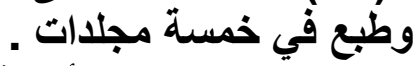

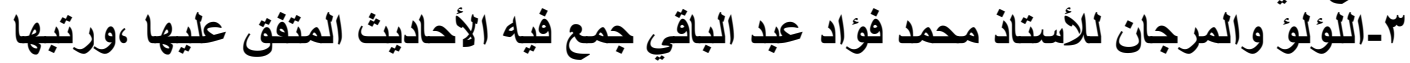

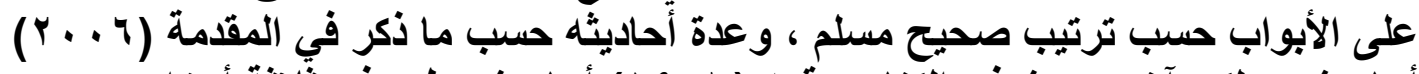

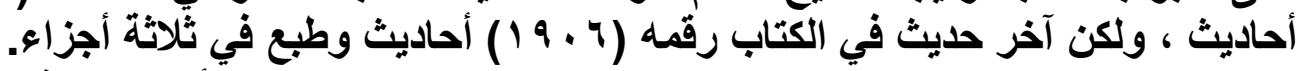

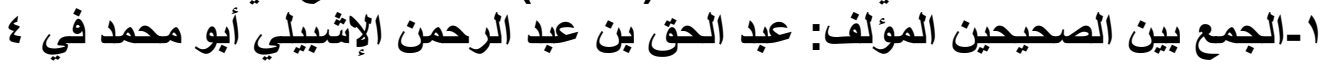
مجلدات إنع ץ- الجمع بين الصحِيحين البخاري ومسلم ل المؤلف: محمد بن فتوح الحميدي في ع مجلدات:

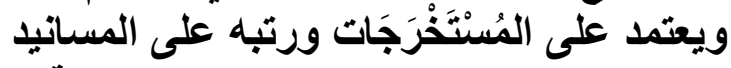

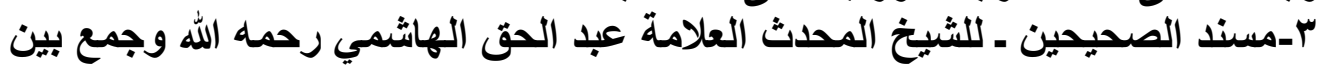
الصحيحين من ناحية المساتيد ومن ناحية الفقه المينه

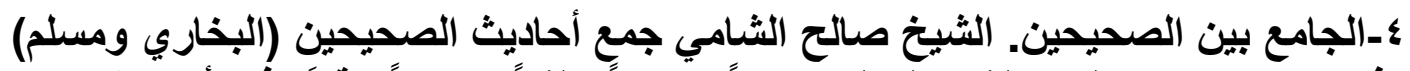

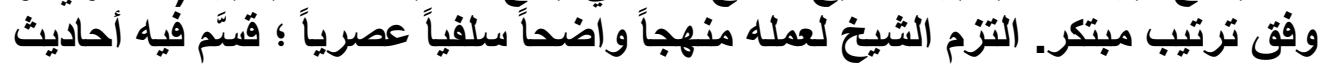

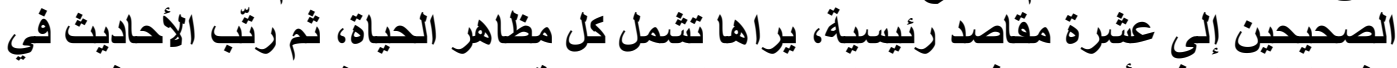

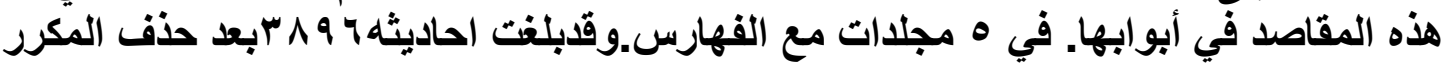

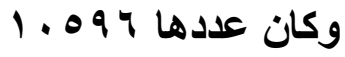
هـالجمع بين الصحيحين البخاري ومسلم و يحيى بن عبد العزيز اليحيى في 1 مجلدات الناشر: دار ابن الجوزي هـ" الموثق " و للشيخ صالح الشقيق كتاب مختصر اسمه جمع فيه أحاديث الأحكام من

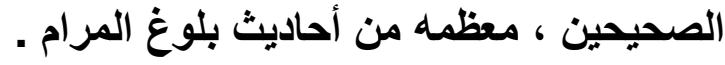

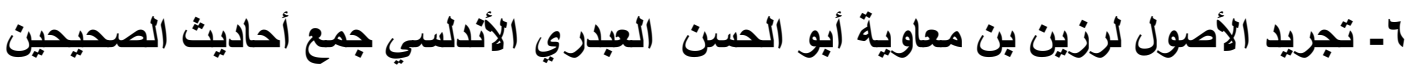

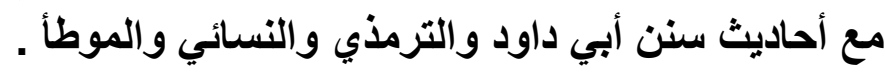

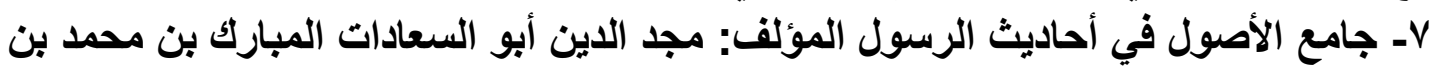

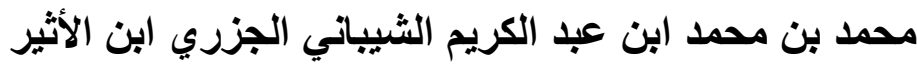


المطلب الخامس : الانتقادات الموجه لصحيح مسلم والرد عليها: ذكر ابن حجر في مقدمة القتح أن الارقطني وغيره من الحفاظ انتقدوا على الصحيحن مائتين

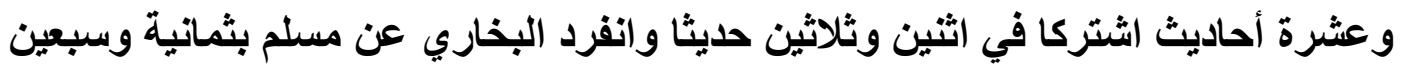
حديثا، وانفرد مسلم عن البخاري بمائة حديث، وقد تولى الحافظ ابن حجر في مقدمة الفتح

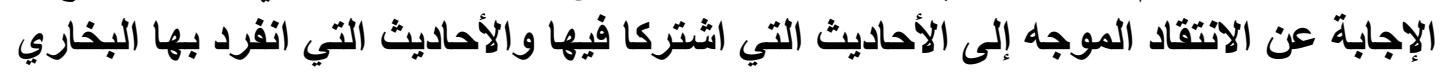

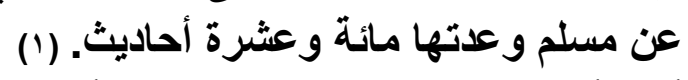

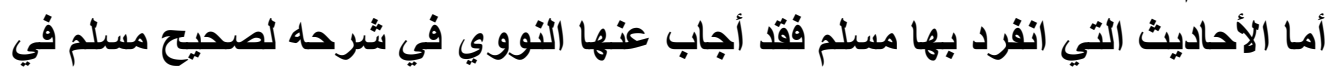

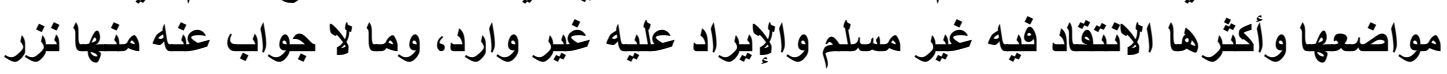

يسير لا يعد شيئا في جنب الآلاف من الأحاديث الصحيحة التي الآنتمل عليها فئا صحيحه.

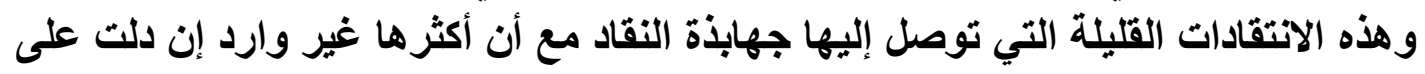

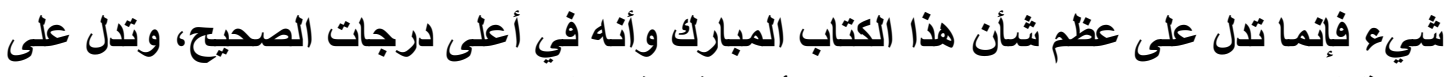

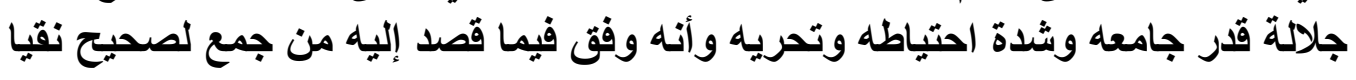

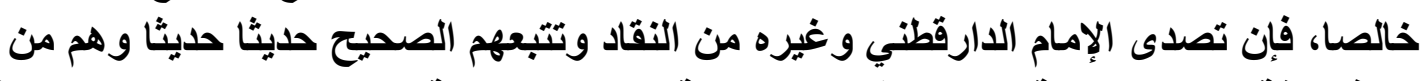

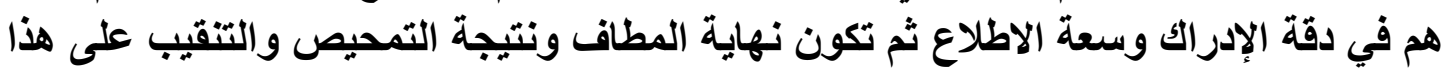

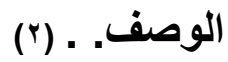

وهذه الانتقادات تتلخص في الاتي:

اولا:وقع في صحيح مسلم بعض الأحاديث التي انتقدت عليه بعضها منصب على الطعن في

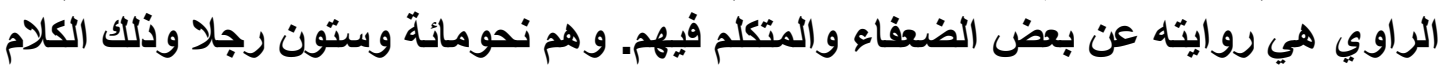
لا يقدح في صحيحه ولا يحط من شأنه لأنه: ولكنه لتزام شرح العلل في بعض الأخبار التي يوردها في مواطنها. لأهاه

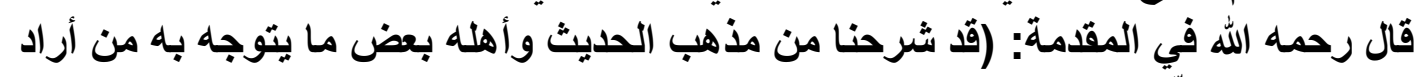

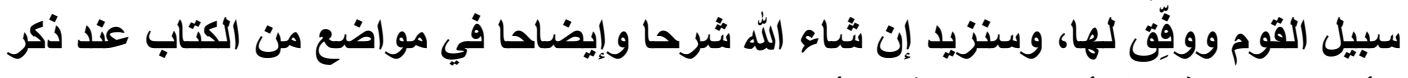

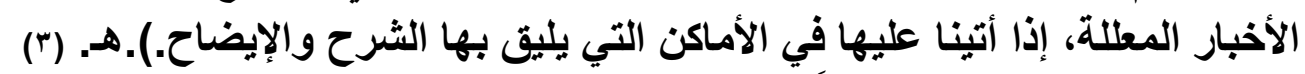

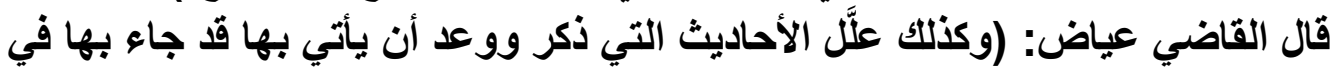

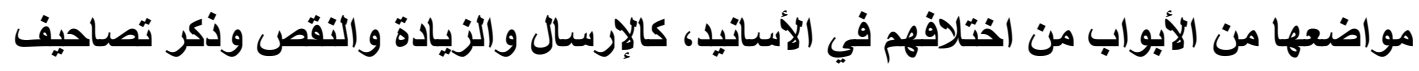

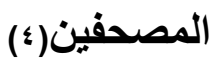

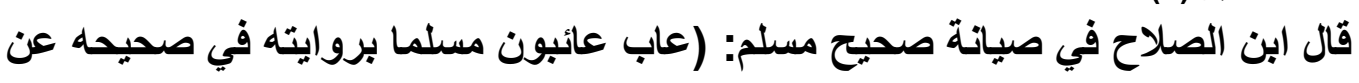

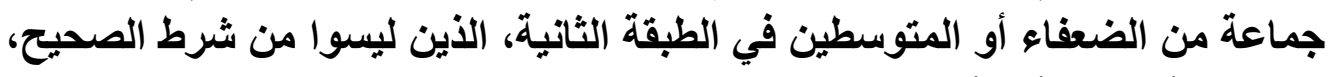

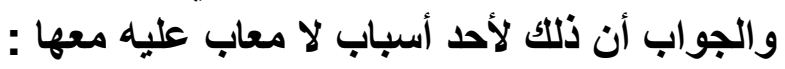
اـ أن يكون ذلك فيمن هو ضعيف عند غيره ثقة عنده، ولا يقال إن الجرح مقدم على التعديل لأن الذي ذكرناه محمول على ما إذا كان الجرح غير مفسرا السبب فإنه لا يعمل بها، ويحتمل

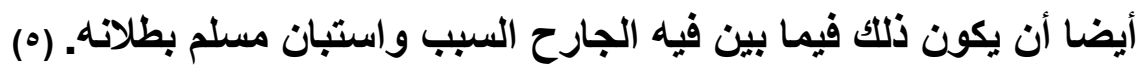

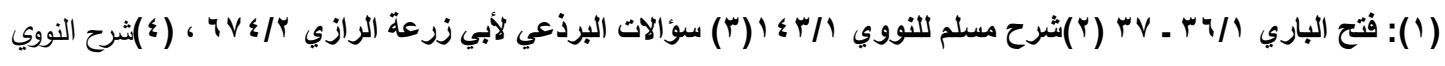

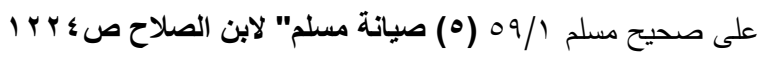


قال الخطيب البذادي كما في مقدمة شرح صحيح مسلم للنووي: "ما احتج البخاري ومسلم

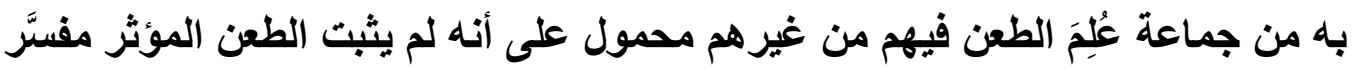

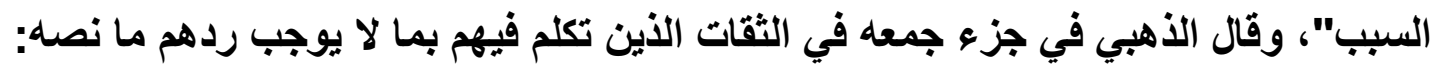

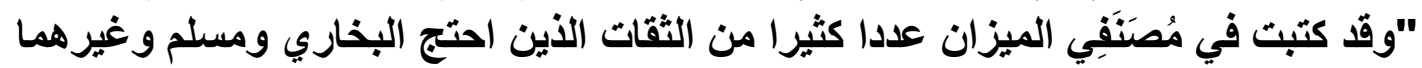

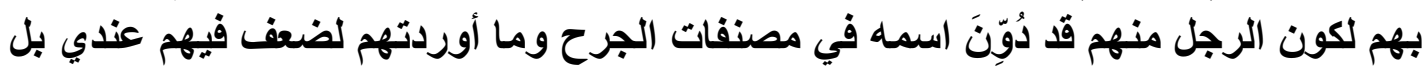

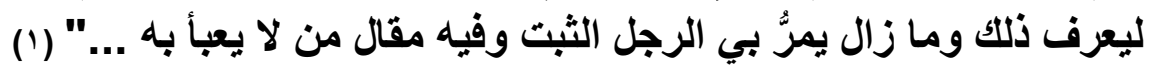

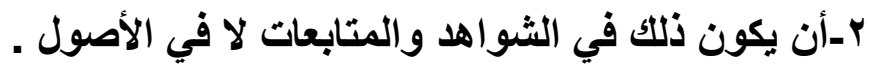

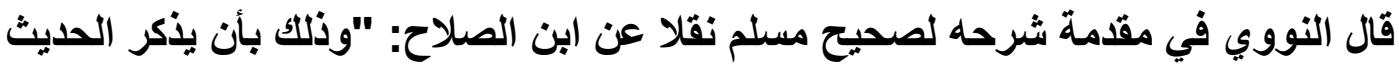

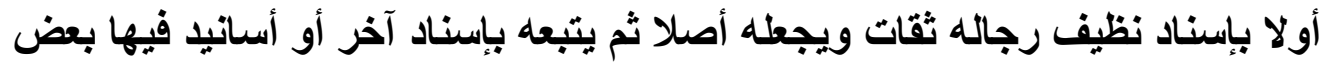

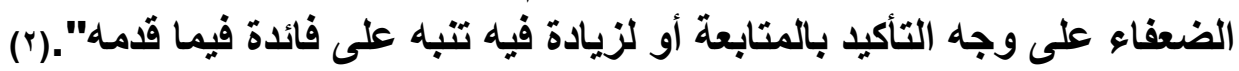

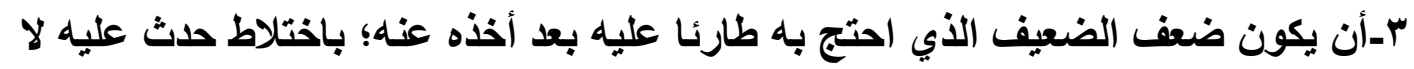

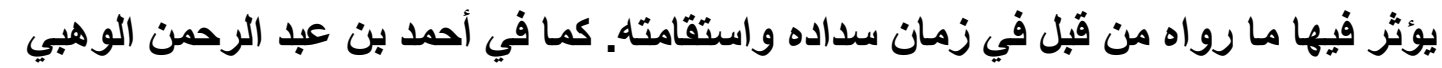

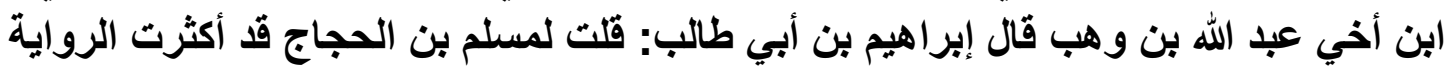

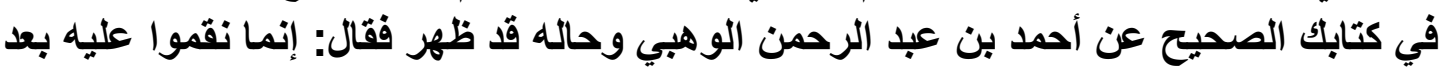

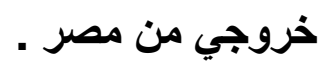

ـ ـ-أن يطلو بالثخص الضعيف إسناده وهو عنده برواية الثقات نازل فيذكر العالي ولا يطول

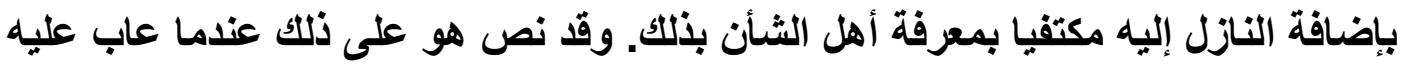

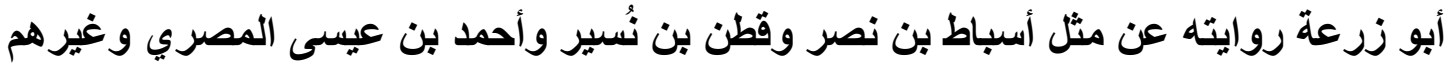

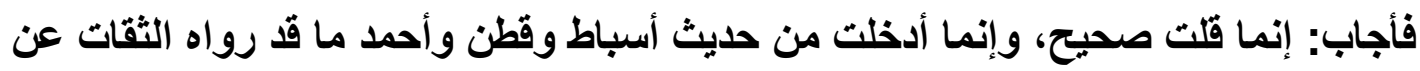

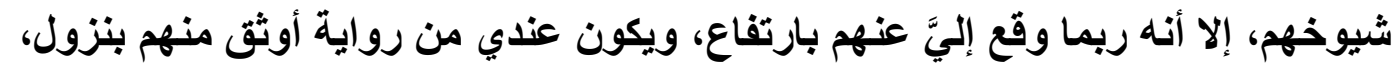

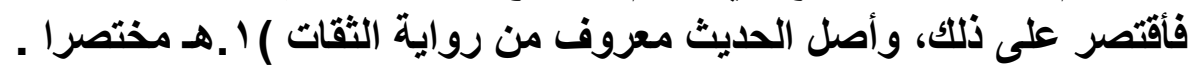

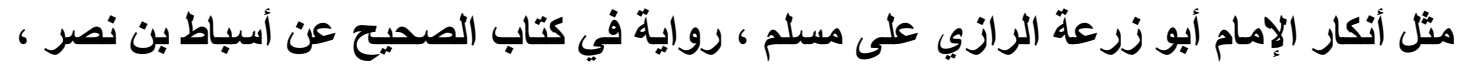
وقطن بن نسير وأحمد بن عيسى.

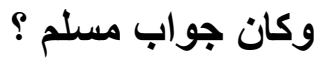

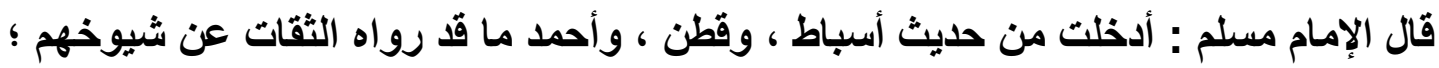

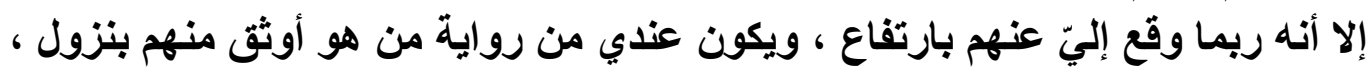

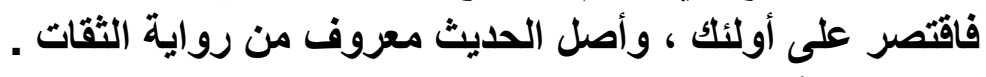

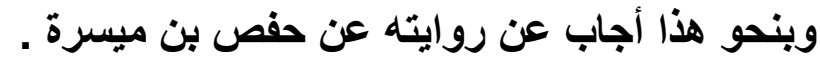

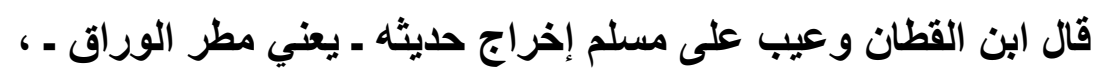

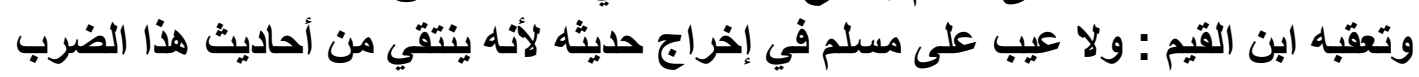

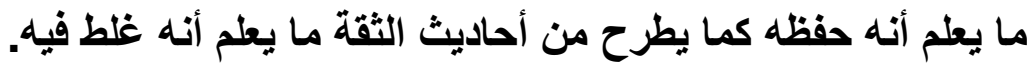


فغلط في هذا المقام من استدرك عليه إخراج جميع حديث الثقة ، ومن ضعف جميع حديث

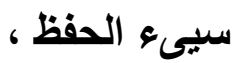
فالأولى: طريقة الحاكم ، وأمثاله. والثانية: طريقة أبي محمد بن حزم ، وأشكاله ، وطريقة مسلم هي طريقة أنمة هذا الثأن أن يكون صاحب الصحيح تجنب ما أنكر على الرجل المتكلم فيه. قال الحافظ ابن حجر في

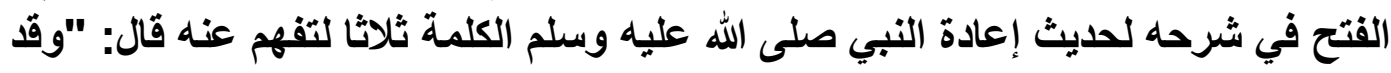

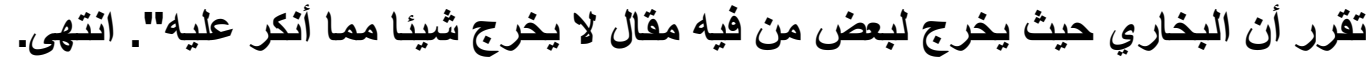

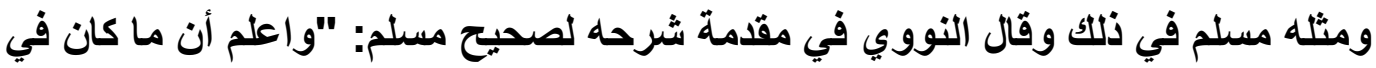

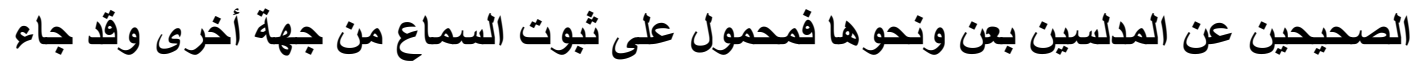

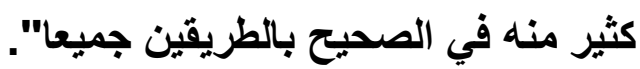

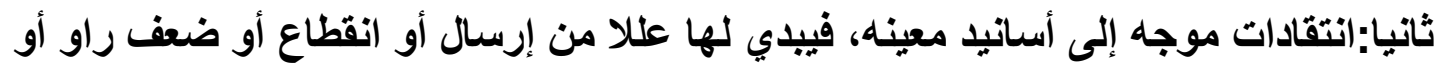

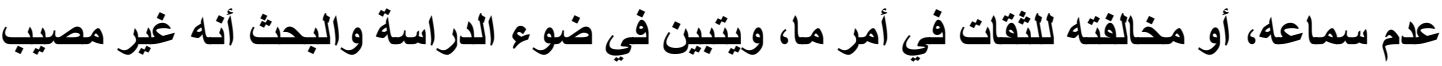

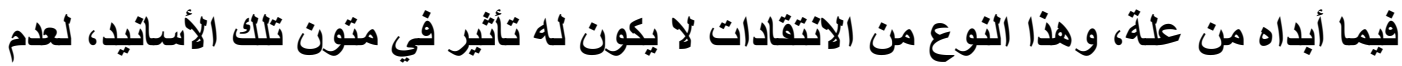

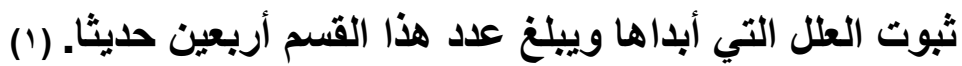

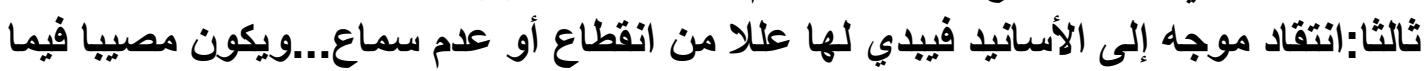

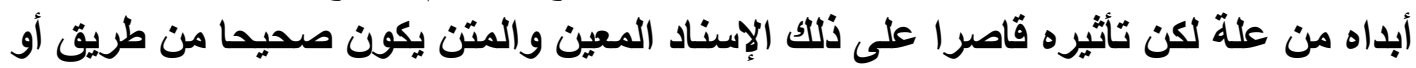

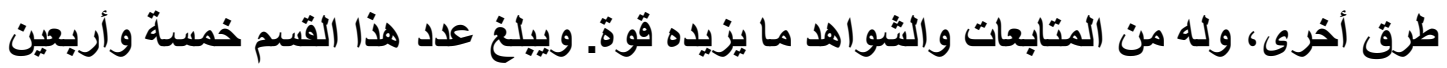
حيثا.

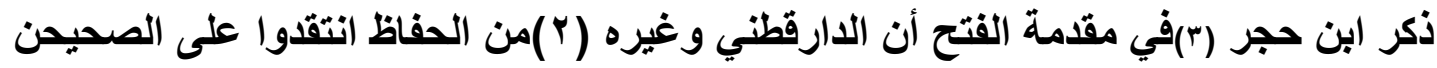

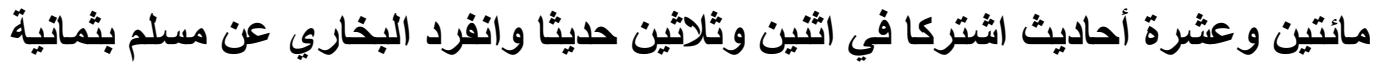

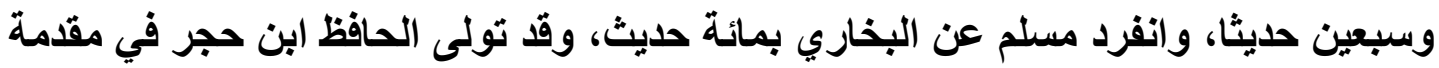

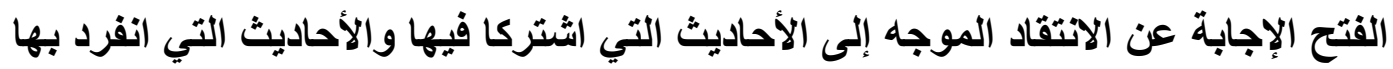

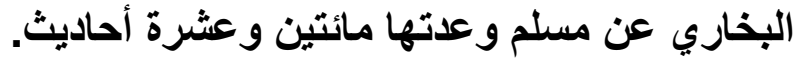

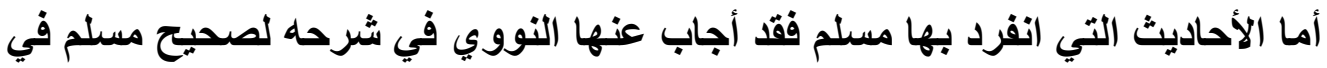

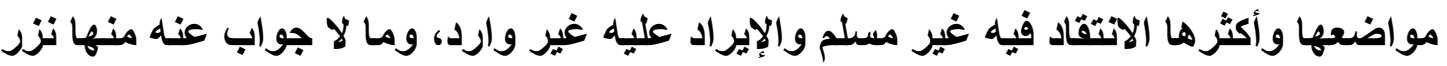

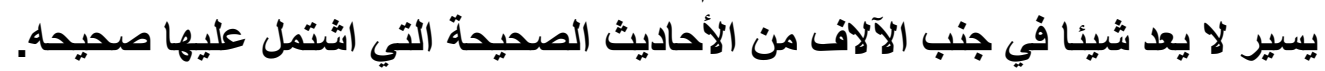

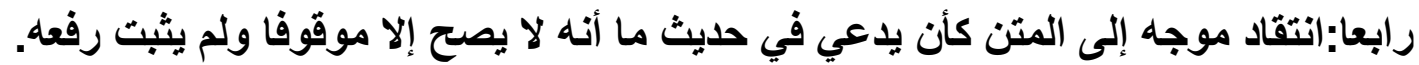

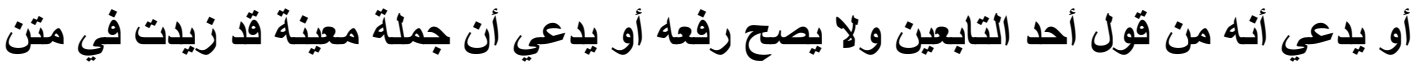

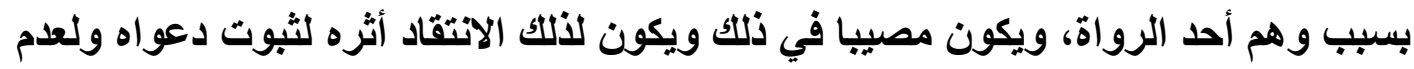
المتابعات والثواهد لذلك المتن وهذا النوع قليل جذا لا يجاوز ثمانية أحاديث. 
خامسا: انتقاد موجه إلى المتن كأن يدعي في حديث ما أنه لا يصح إلا موقوفا عن صحت صحابي

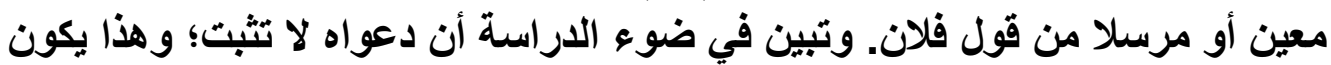

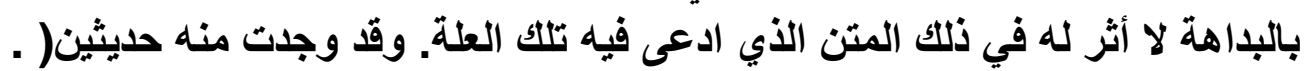

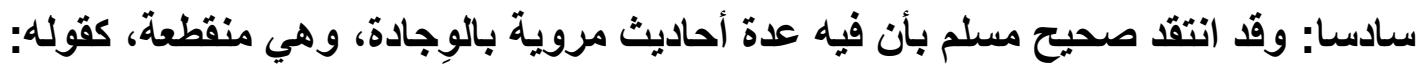

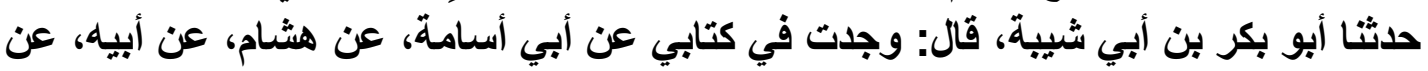

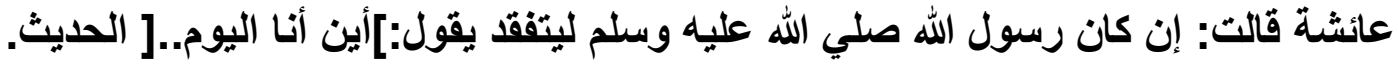

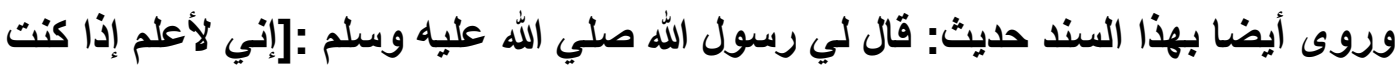

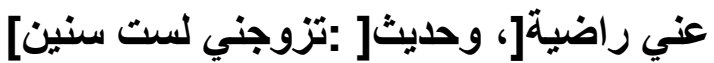

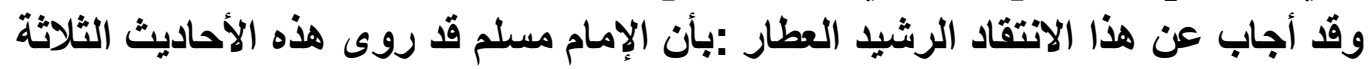

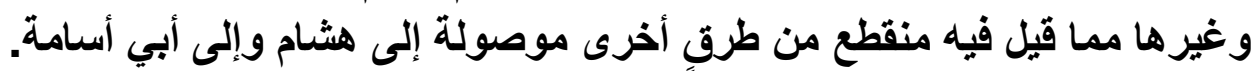

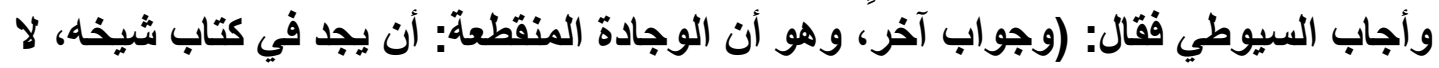

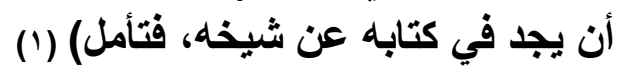

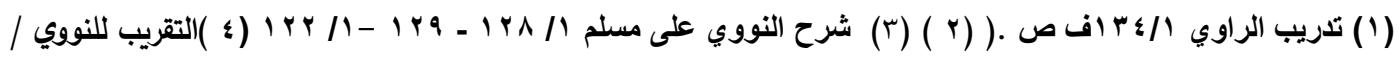

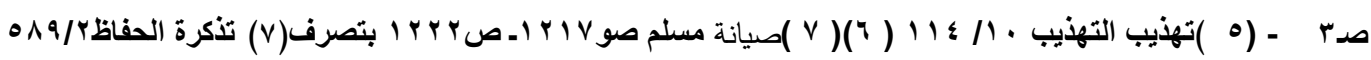

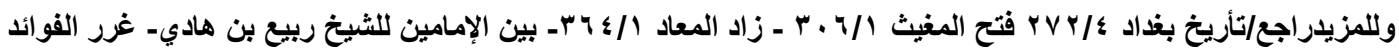

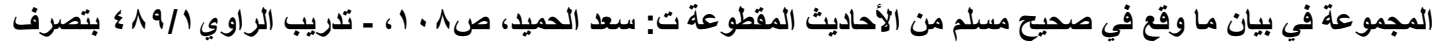

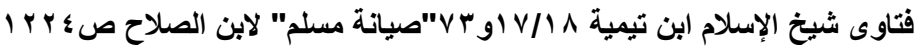


(1): المطلب السادس طبعات كتاب صحيح مسلم

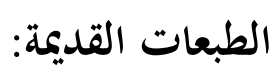
طبع صحيح مسلم طبعات كثيرة جدا قديمة ، وحديثة مفردة ومع الشروح منها ما كان في

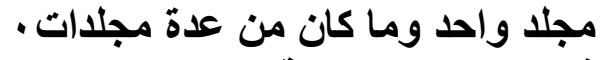

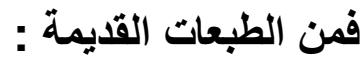

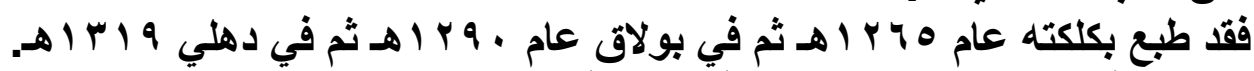

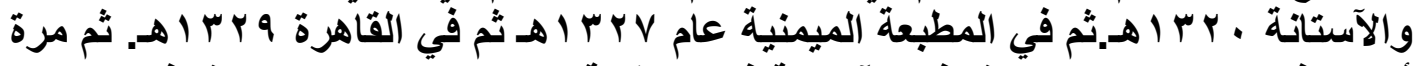

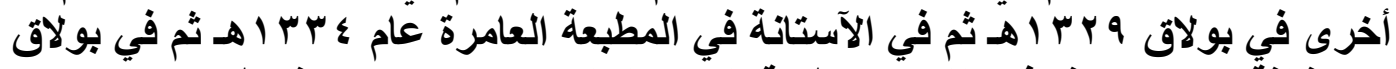

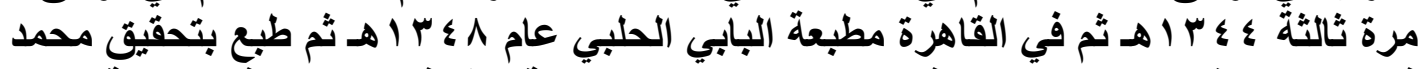

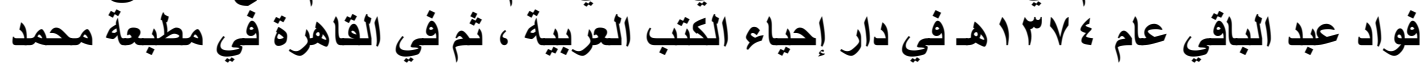

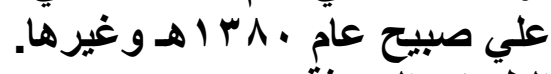

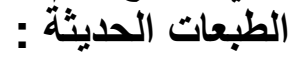

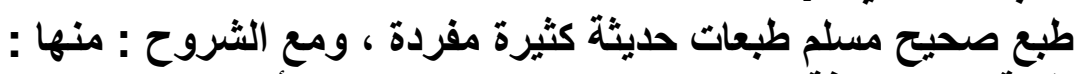

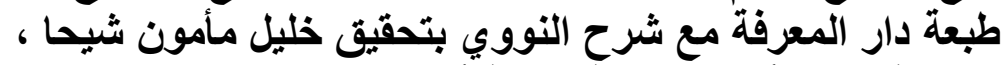

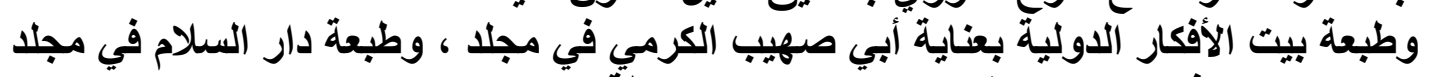

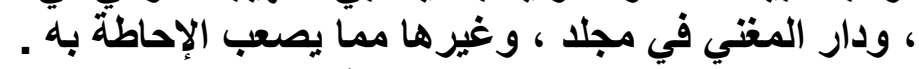

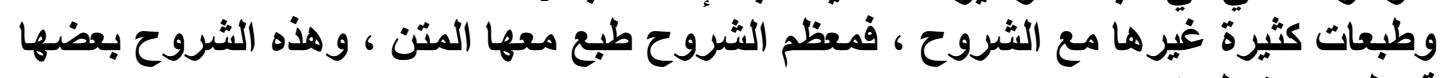

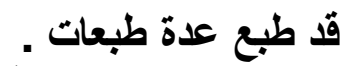

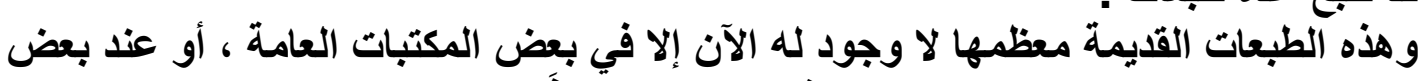

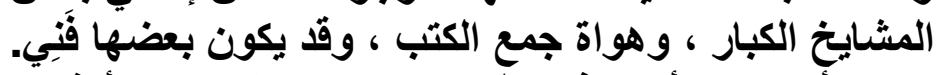

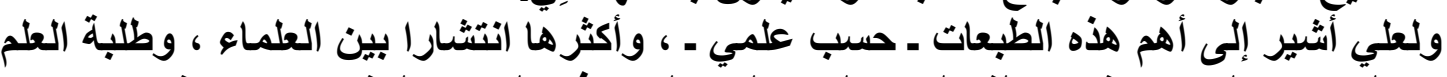

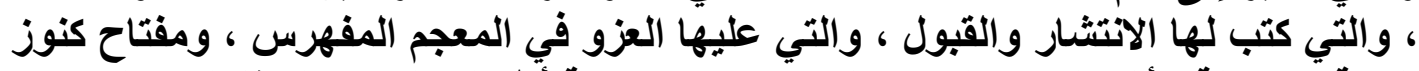

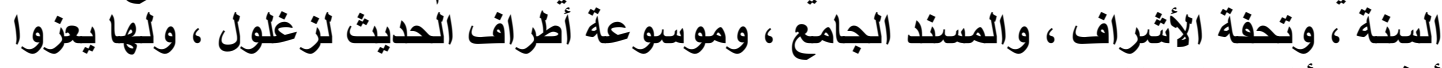
أكثر ، وأشهر المحققين.

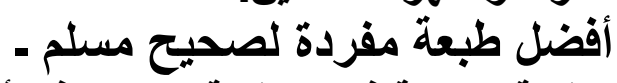

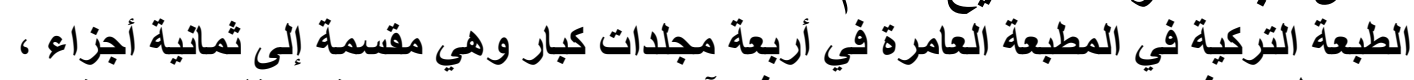

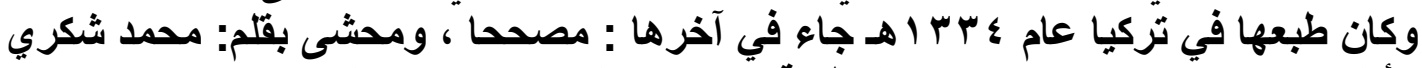

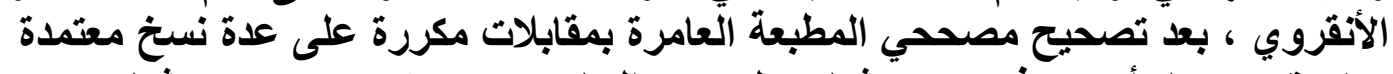

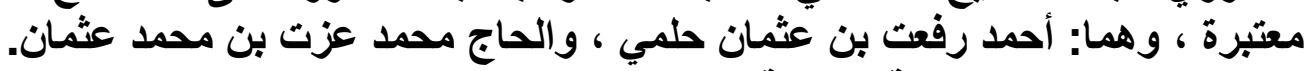

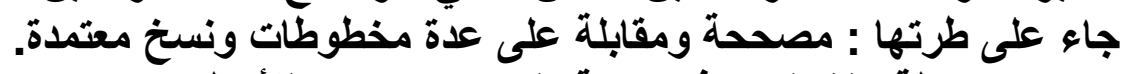

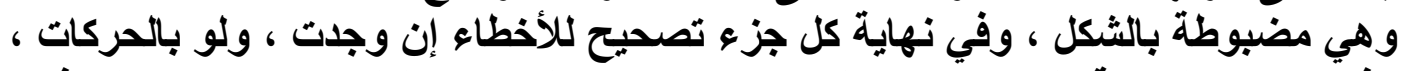

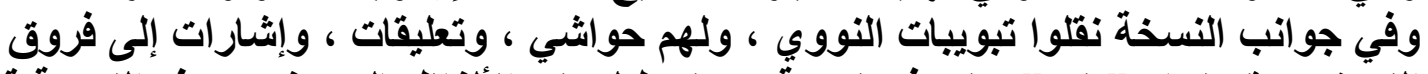

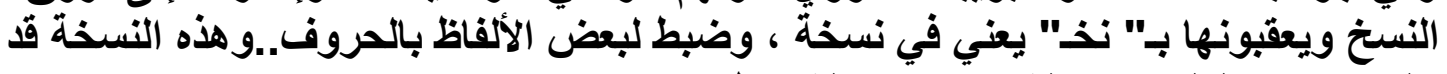

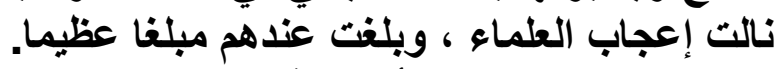

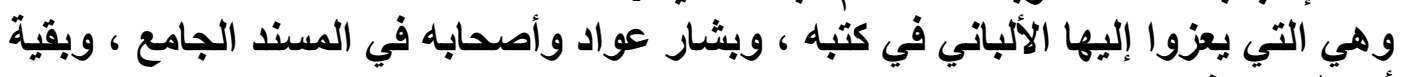

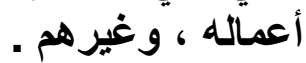
و هذه الطبعة قد صورث أله هدة مرات في دار المعرفة ، و الجيل ، والفكر ..

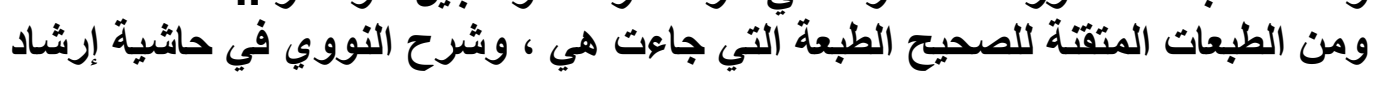

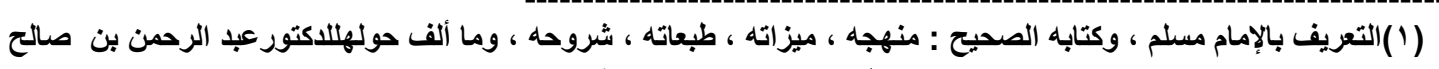

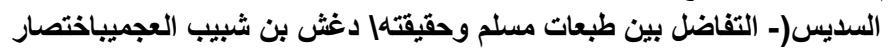




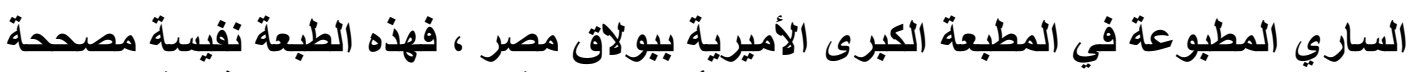

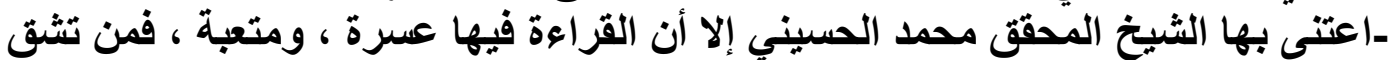

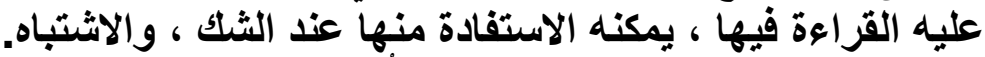

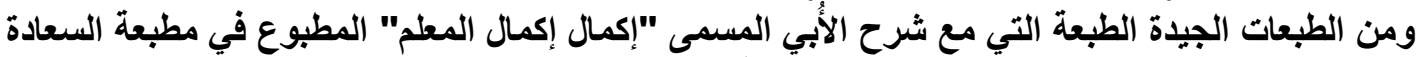

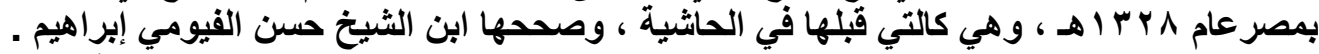

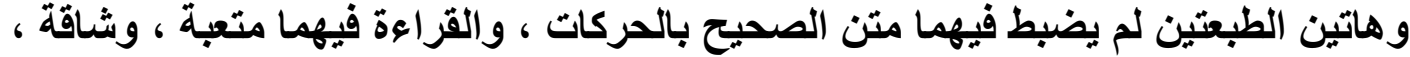

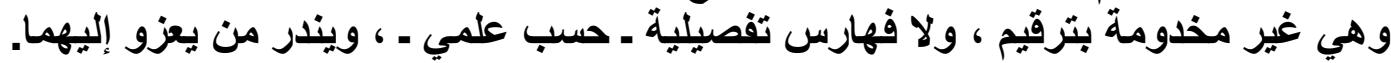

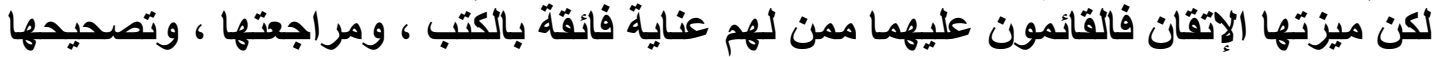

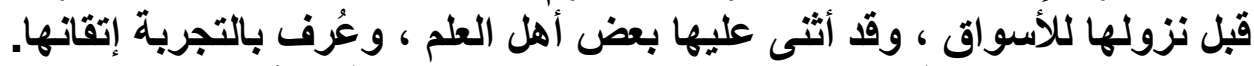

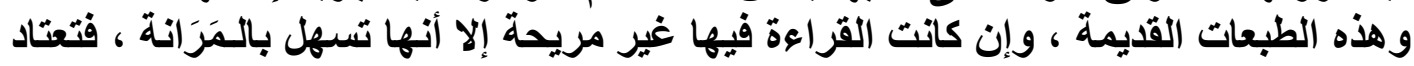

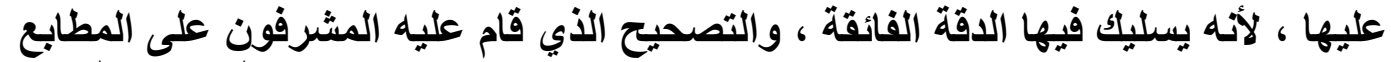

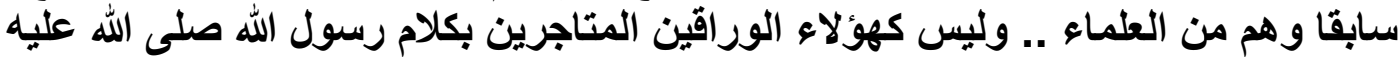

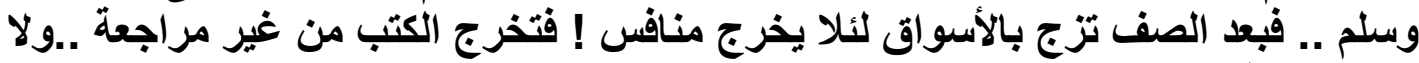

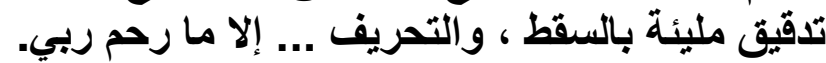

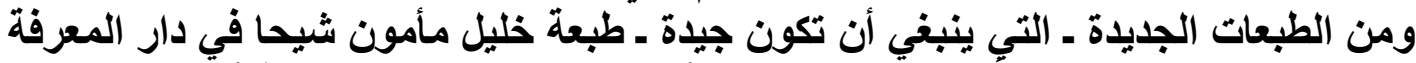

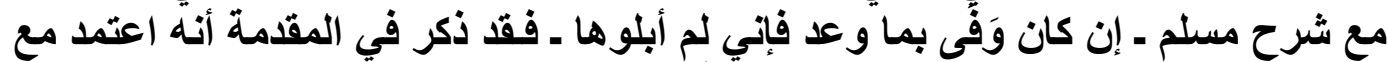

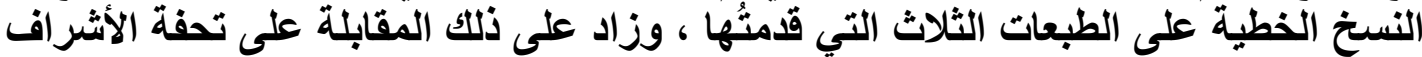

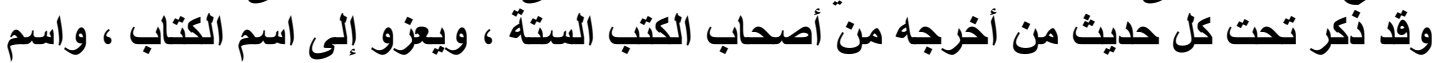

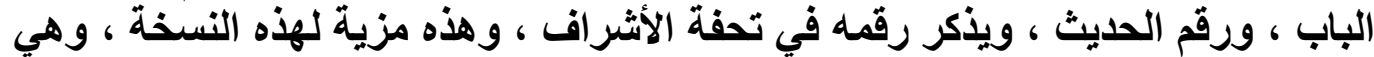

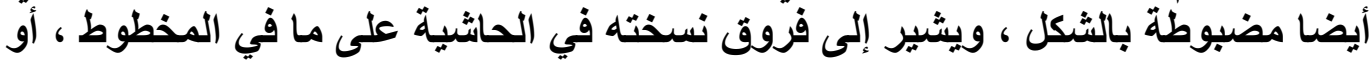

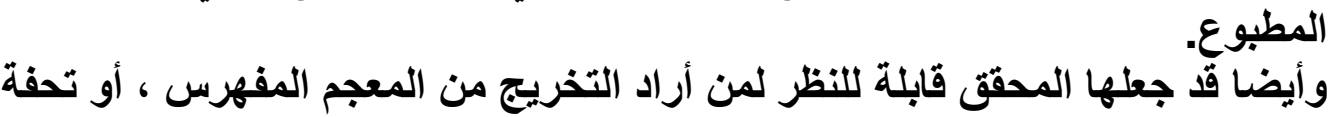

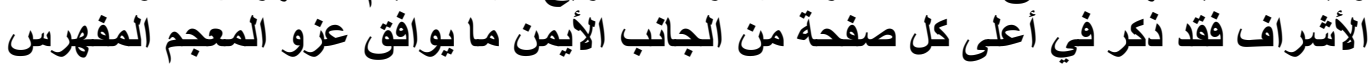

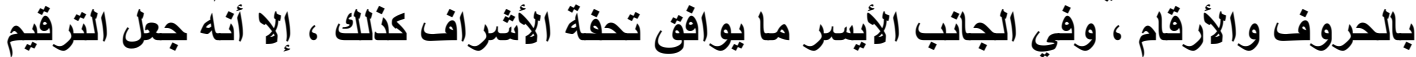

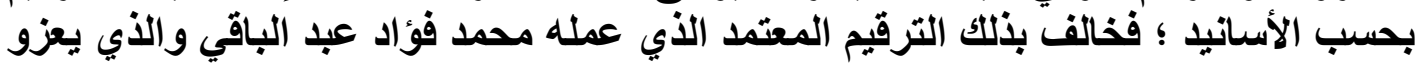

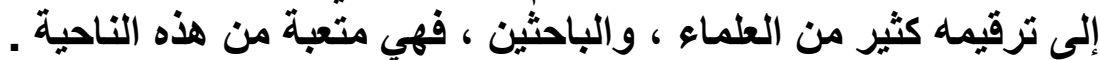

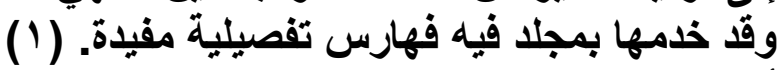

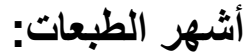

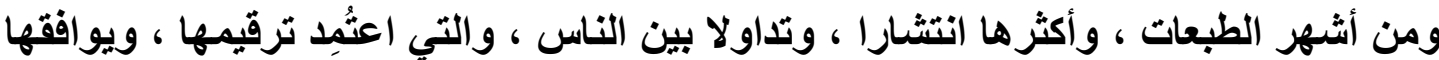

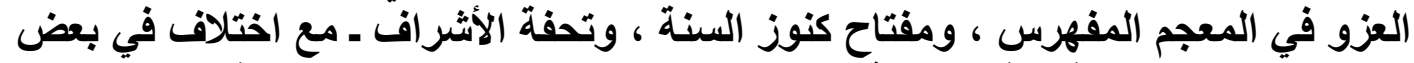

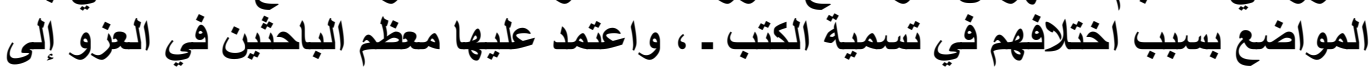

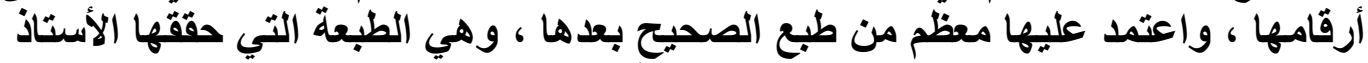

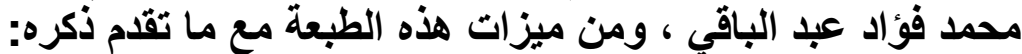

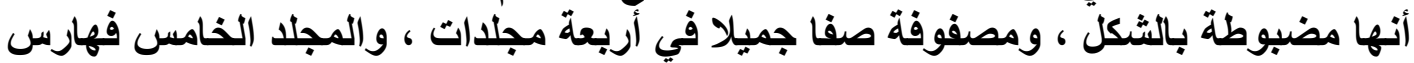

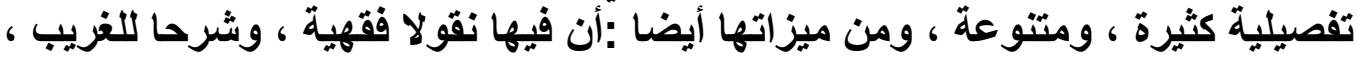

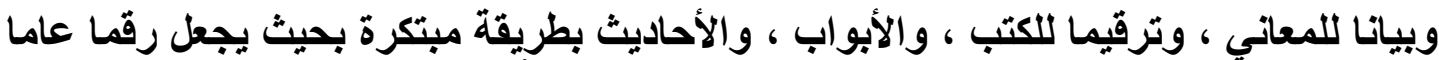

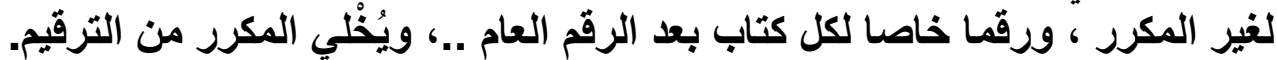

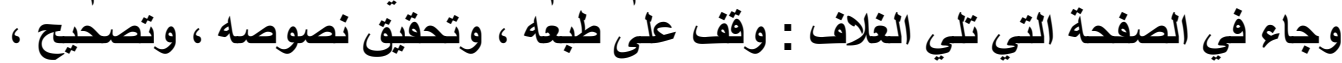

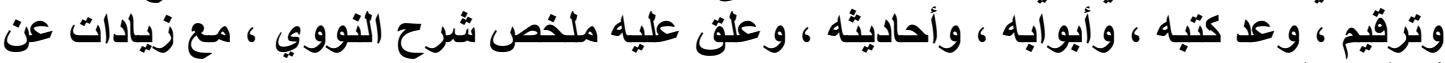

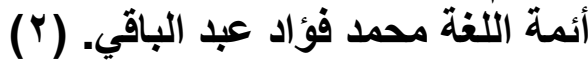

(1) التعريف بالإمام مسلم ، وكتابه الصحيح : منهجه ، ميزاته ، طبعاته ، شروحه ، وما ألف حولهلادكتورعبد الرحمن بن صالح

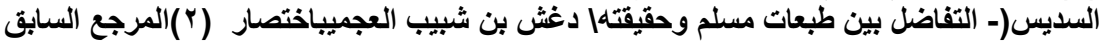


الملاحظات على هذه الطبعة : لم يبين هل أخذ المتن من المطبوعات السابقة ، أو اعتمد على ألى

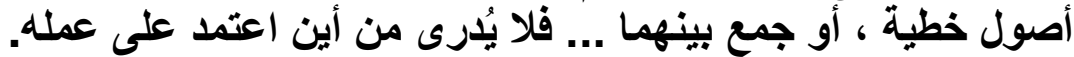

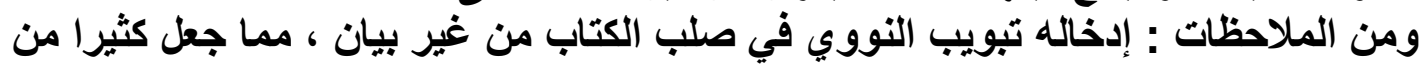

الناس ، بل طلبة العلم يظن أن التبويب لمسلم ، في في قيل فيل : وبوب عليه مسلم في صحيحه

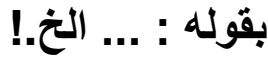
وهذا الإدخال خطأ، فلو أنه ـ رحمه الله ـ فعل كما فعل أصحاب الطبعة العامرة من جعل التبويب

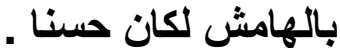

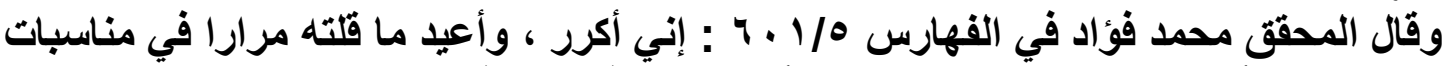

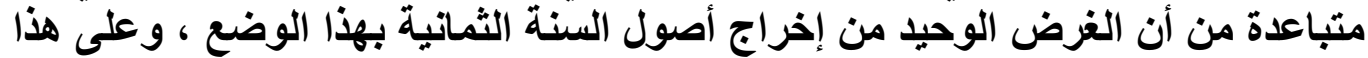

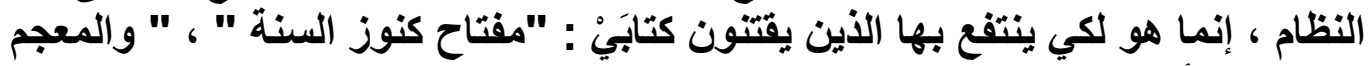

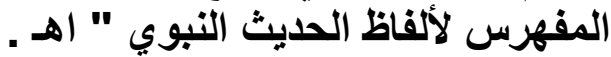

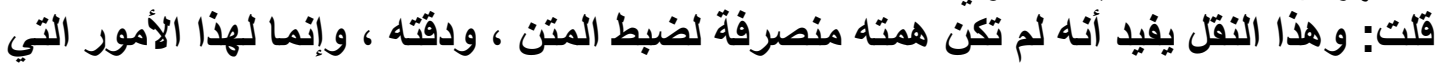
ذكرها ، ولذا جاعت هذه الخدمات الكبيرة في نسخته ... ، وتبعها أخطاء في صلب الكتاب. وق وضع المحقق ـ رحمه الله ـ تصحيحا لبعض الأخطاء التي وقعت في طبعته في آخر المجلا

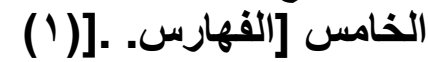
الطبعات ذات المجلد الواحد: الطبعات ذات المجلد الواحد كطبعة أبي صهيب الكرمي ، واتوات أظنها أوله أول الطبعات التي صدرت في مجلا واحد فقد ذكر المحقق ص 9 : أُنها أخذها من طبعة محمد فؤاد عبد الباقي ووصفها بأنها

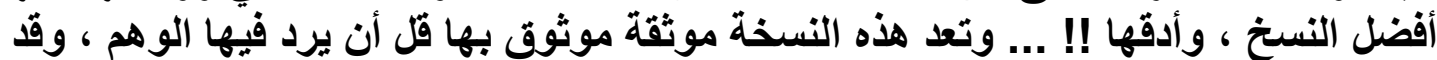
صححنا الأخطاء الواردة فيها ، وأتممنا السقط في بعض المضات المواضع التي سقط منها كلمات

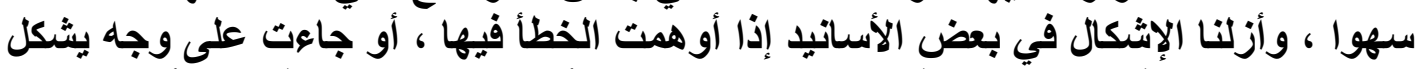

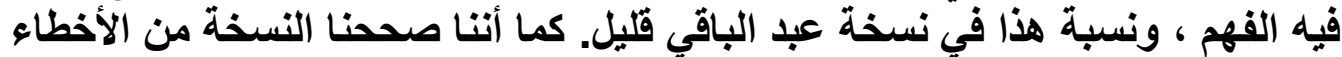

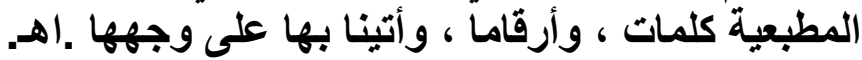

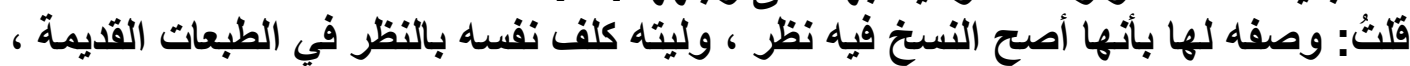

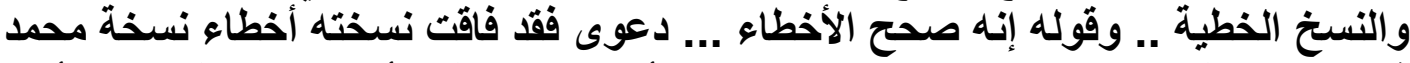

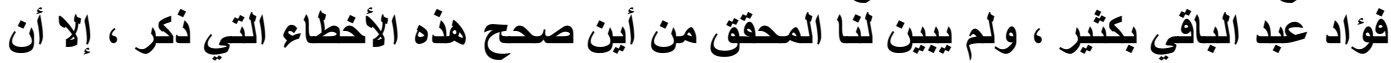

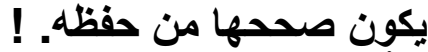

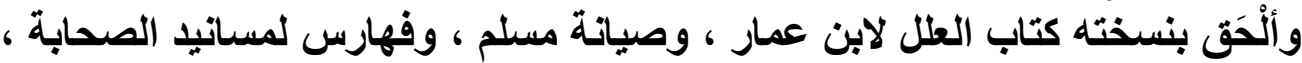

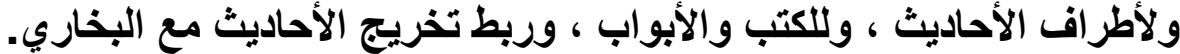

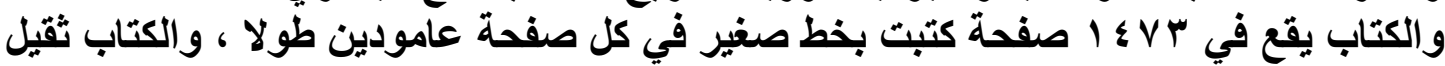
حمله ، صغير خطه ، قليل ضبط فئه

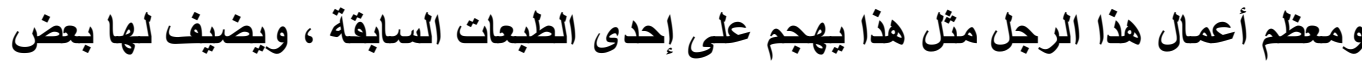

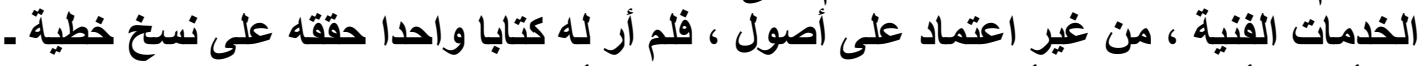

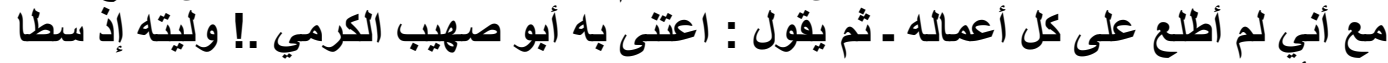

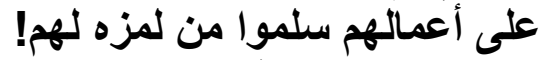
وهذه ظاهرة قبيحة انتشرت بين كثير من المحققين ، يبنون كتبهم على أعمال الآخرين ،

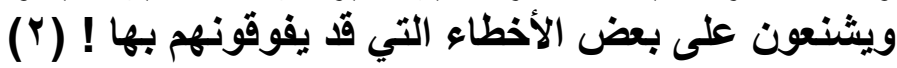


جهود وزارة الأوقاف والثؤون الإسلامية بالكويت:(1)

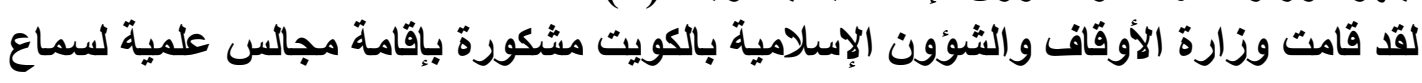

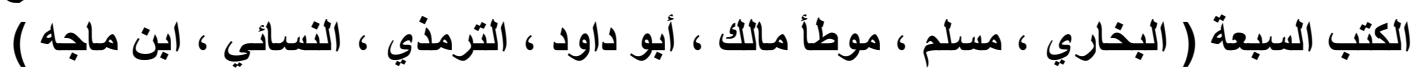

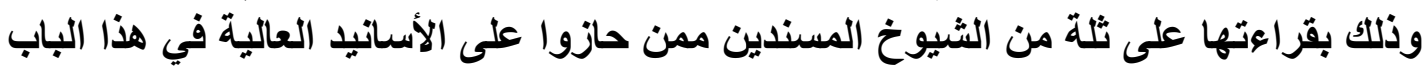

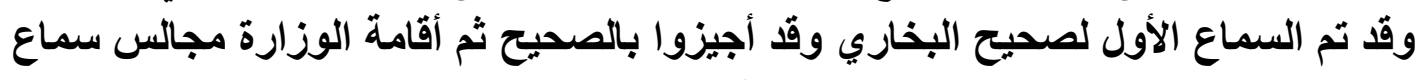

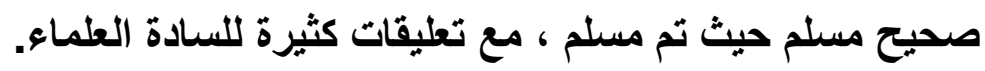

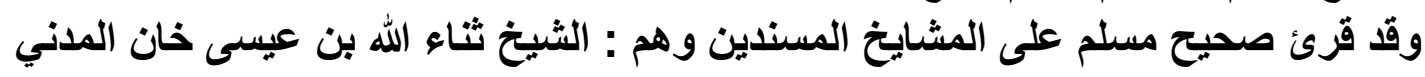
من باكستان ، والثيخ مساعد بن بشير بن علي الحسيني من السودان ، والثيخ عبد الثبن الوكيل

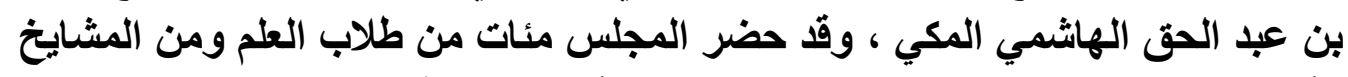
الأفاضل من داخل وخارج الكويت ، وقد كان يقرأ عليهم ستة من طفي طلاب العلم بالتناوب بينهم.

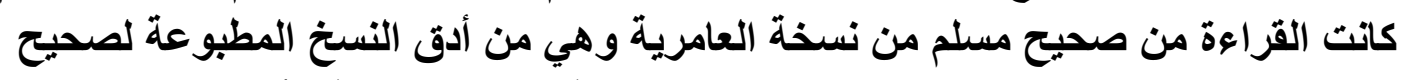

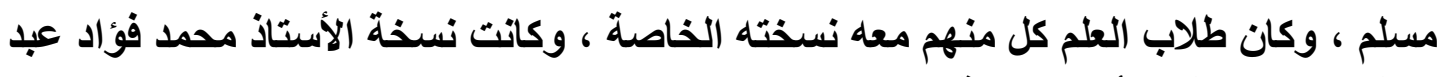

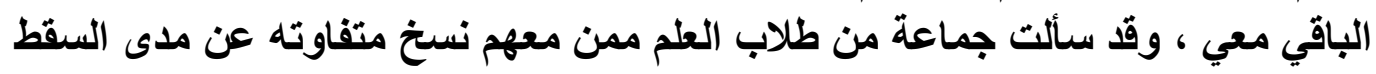

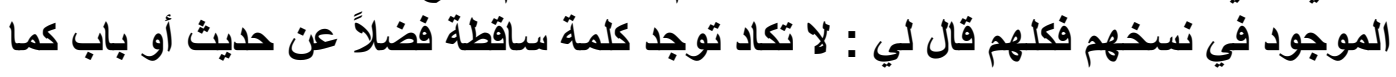
ولعل من أكثر ما سمعت طلاب العلم يتكلمون فيه من النستخ من حيث السوء طبعة بيث الأفكار

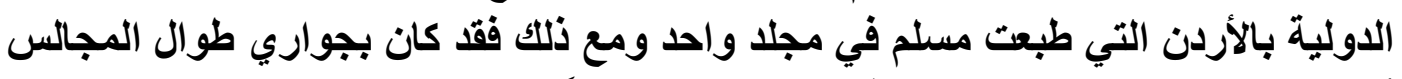

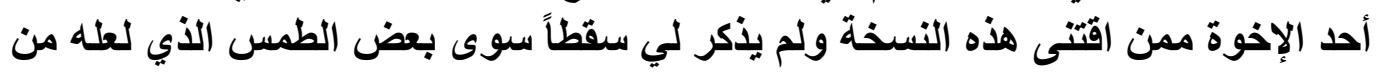

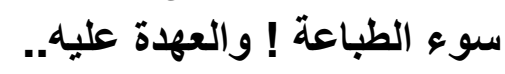
وإليك النسخ التي سألت أصحابها عن السفط علد علده هم وجاويوني بالنفي:

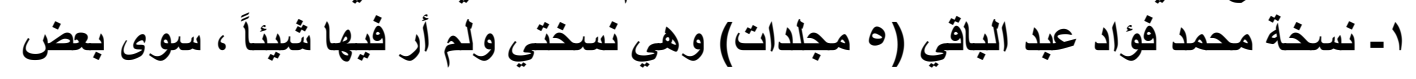

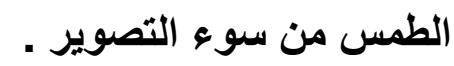

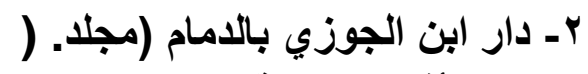

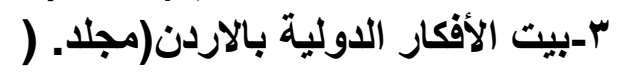

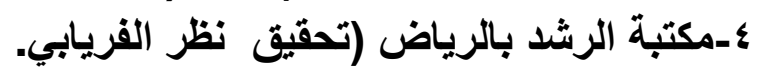
هـدار المعرفة ببيروت مجلد.

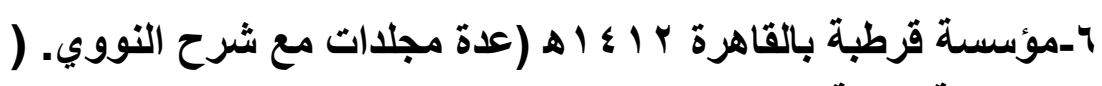
V-العامرية نسخة المشايخ والقراء. وهنا لي بعض التبييهات: الأول : الرد على أهل البدع الأين بشككون في نسخ صحيح مسلم التي بين أيدينا ويزعمون

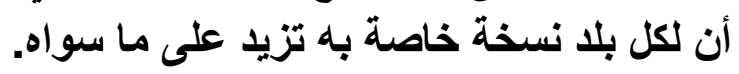

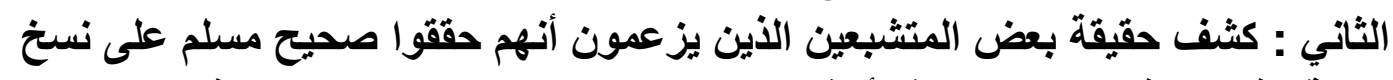

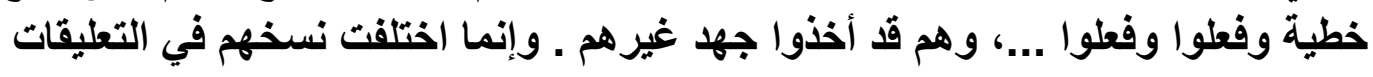

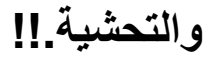


الثالث : الاور التي تزعم أنها شكلت لجنة للعناية بمسلم وتحقيقه وهي قد أخذت جهد وعناية غيرها ولم تذكر ذلك.

والظاهر أن التشابه بين النسخ التي طبعت مسلم هو ناتج عن أخذهم من نسخة واحدة وأصل

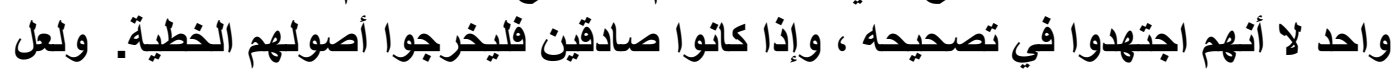

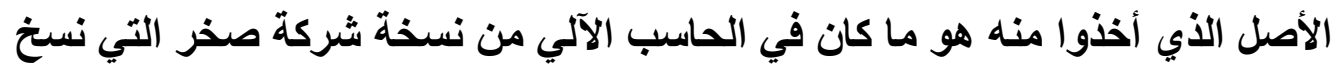

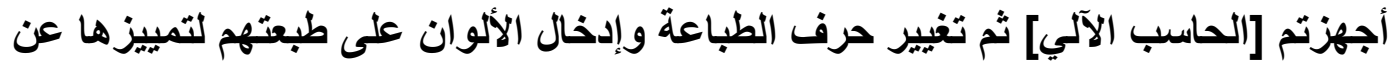

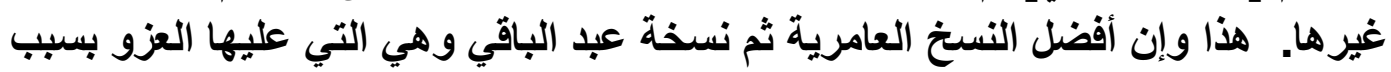
الترقيم والعناية بالفهرسة... 


\section{الخاتقة}

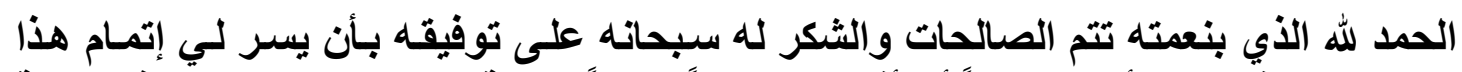

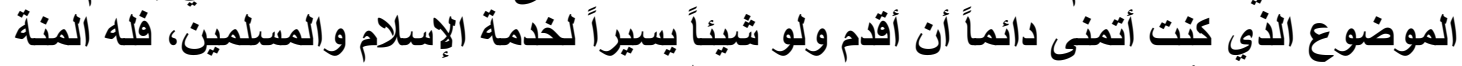

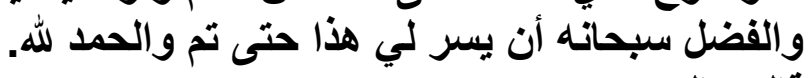

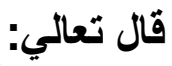

( ربّ أوزعني أن أشكر نعمتلك التي أنعمت علي وعلى والدي وأن أعمل صالحاً ترضاه،

وأدخلي برحمتك في عبادك الصالحين) سورة النمل، الآية: 19

فإنني وبعد دراستي لهذا الموضوع الهام؛ توصلت إلى النتائج الآتية:

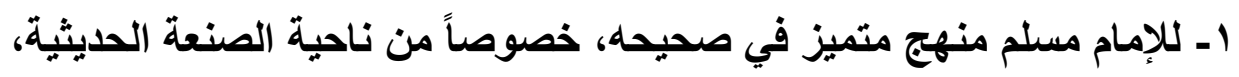

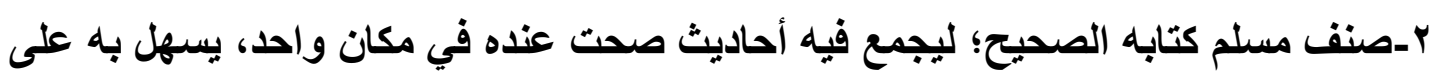

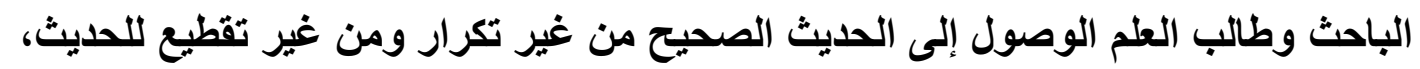

r-الإمام مسلم يعتني بالترتيب في كتابه كما قال في مقدمته، وقد وجدت من خلال أحاديث هذه الإنه

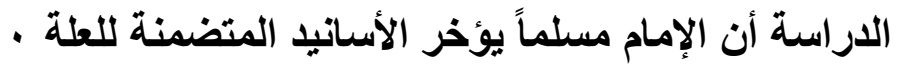




\section{قائمة المراجع والمصادر}

- إبراهيم بن محمد بن سفيان رواياته وزياداته وتعليقاته على صحيح مسلم، تأليف: عبد الله

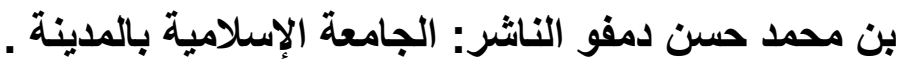
-الإمام مسلم وصحيحه بقلم الثيخ: عبد المحسن العباد

ـ إكمال المعلم بفوائد مسلم - الكاتب:القاضي عياض بن موسى - المحقق:يحيى إسماعيل -

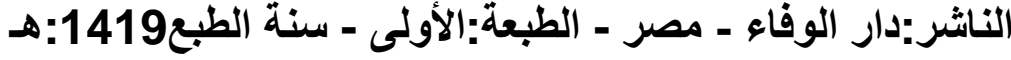

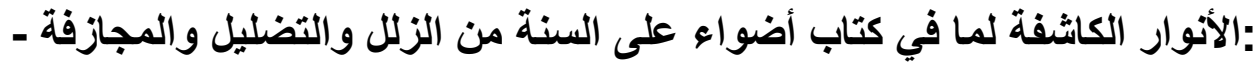

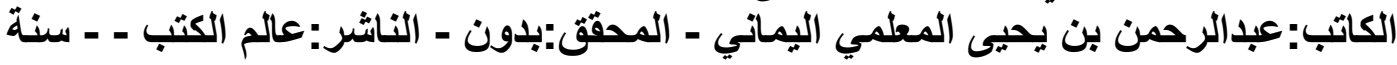
الطبع1403:هـ :الإرشاد في معرفة علماء الحديث ـ الكاتب:الخليل بن عبدالله القزويني - المحقق:محمد سعيد

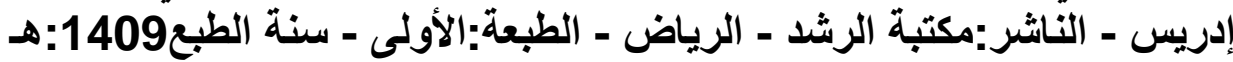

:الإصابة في تمييز الصحابة ـ الكاتب:أحمد بن علي بن حجر العسقلاني - المحقق:بلون -

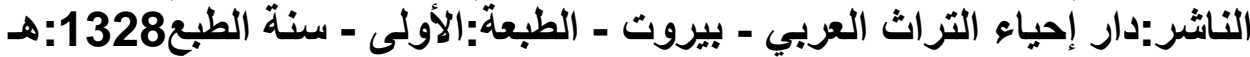

:الإلزامات والتتبع - الكاتب:علي بن عمر الدارقطني - المحقق:مقبل بن هادي الوادعي -

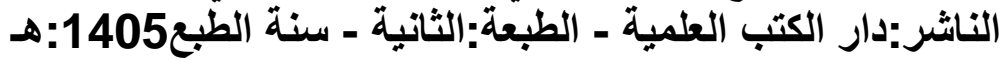

البداية والنهاية ـ الكاتب:إسماعيل بن عمر عماد الاين بن كثير - المحقق:مجموعة محققين -

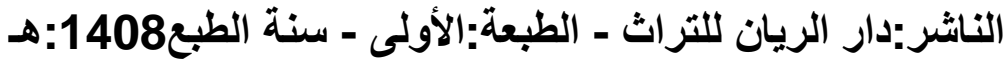

ـتاريخ الأدب العربي لبروكلمان 6مجلات الطبعة الثالثةدار المعارف

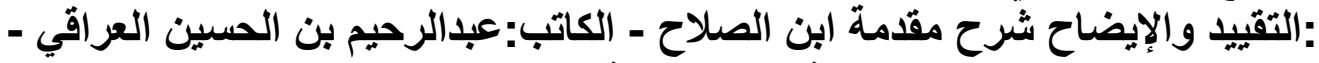

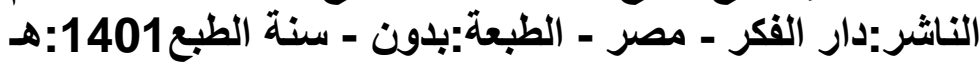

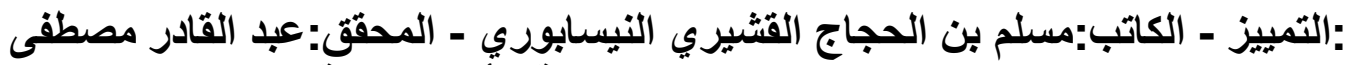

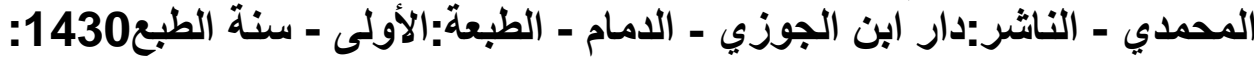

:التنكيل لما ورد في تأتيب الكوثري من الأباطيل ـ الكاتب: عبدالرحمن بن يحيى المعلمي

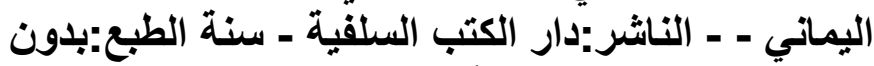

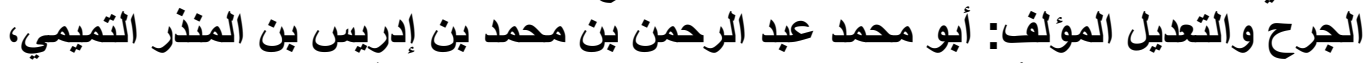

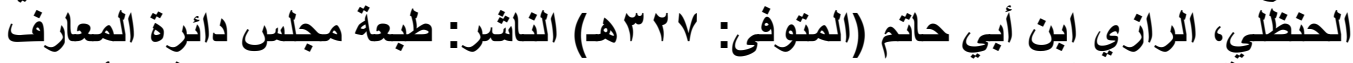

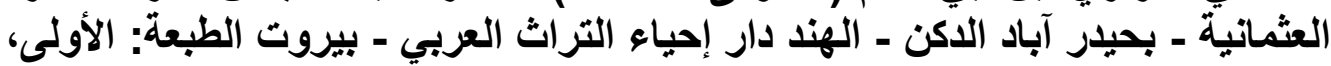

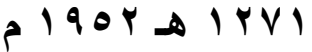

:الفروسية ـ الكاتب:محمد بن أبي بكر بن القيم - المحقق:مشهور حسن آل سلمان -

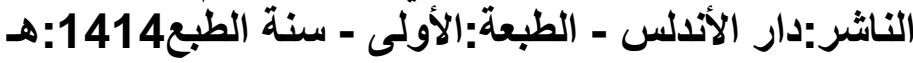




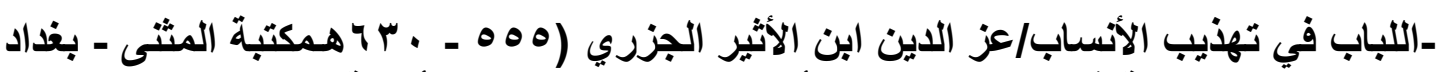

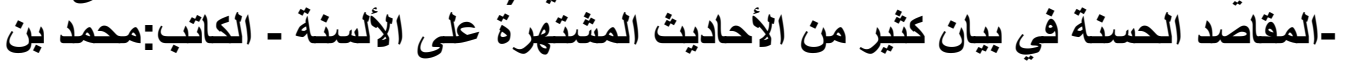

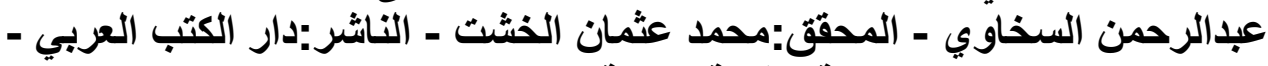

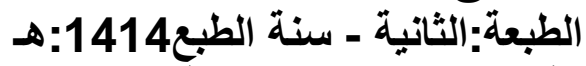

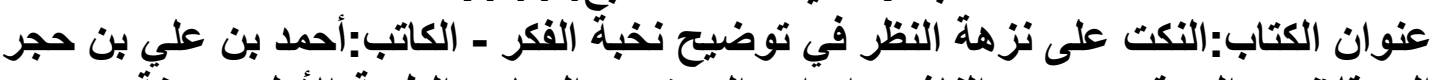

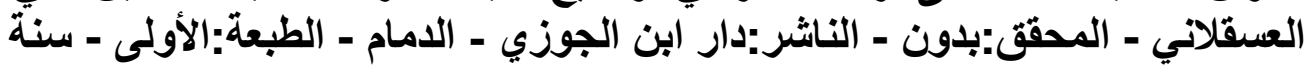
الطبع1413: هـ ـالبدر الطالع بمحاسن من بعد القرن السابع المؤلف: محمد بن علي الشوكاني الناشر: دار

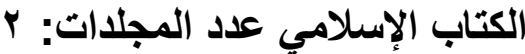

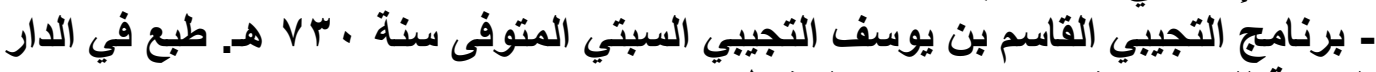

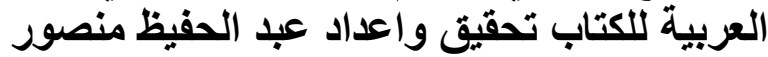

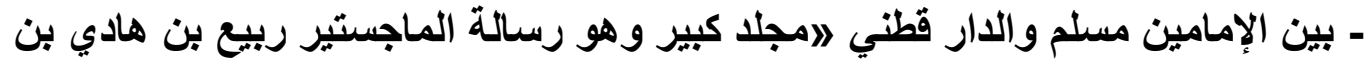

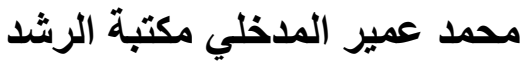

:تاريخ بغداد - الكاتب:أحمد بن علي الخطيب البغدادي - المحقق:مصطفى عبدالقادر عطا -

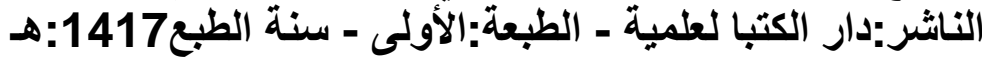

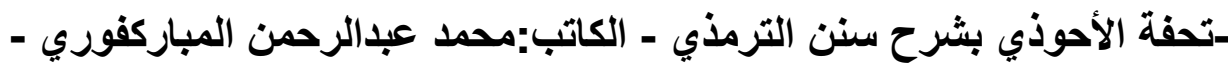

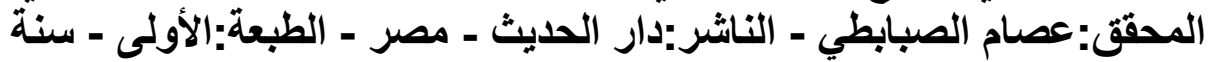

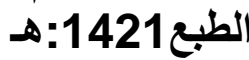

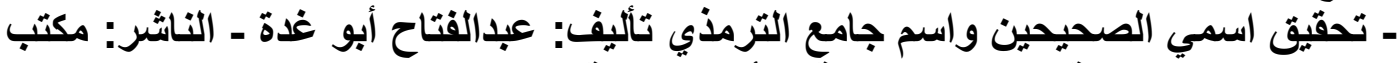

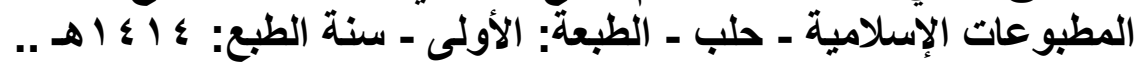

:تلريب الراوي في شرح تقريب النواوي - الكاتب:عبدالرحمن بن أبي بكر السيوطي -

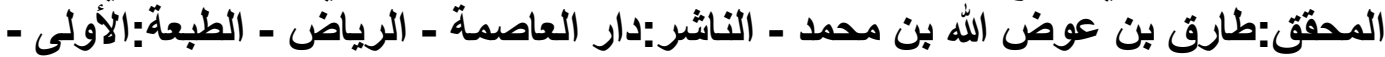

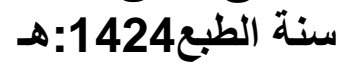

تذكرة الحفاظ محمد بن أحمد بن عثمان بن قايماز الأهبي شمس الدين أبو عبد الله المحقق:

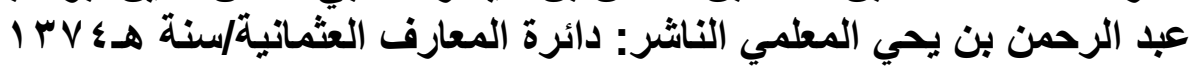

ـالتعريف بالإمام مسلم ، وكتابه الصحيح : منهجه ، ميزاته ، طبعاته ، شروحه ، وما ألف حوله للاكتور عبد الرحمن السديس ومن وكابه

ـ تقريب التهذيب /أحمد بن علي بن حجر العسقلاني أبو الفضل شهاب الدين/ دار

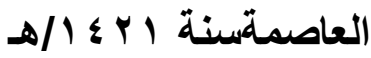

تهذيب الأسماء واللغات/ الكاتب:يحيى بن شرف الدين النووي/ ـ الناشر:دار الكتب العلمية ـ بيروت

:تهذيب التهذيب - الكاتب:أحمد بن علي بن حجر العققلاني - المحقق:بدون - الناشر:مؤسسة

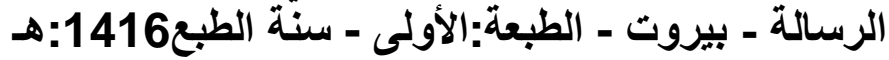

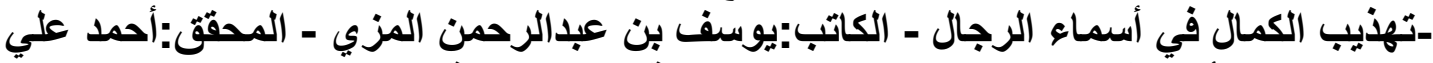

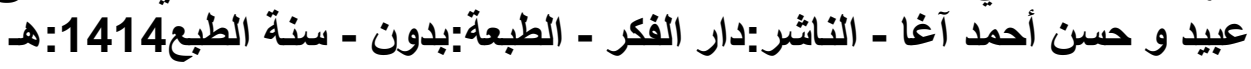




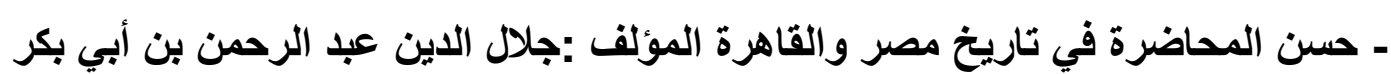

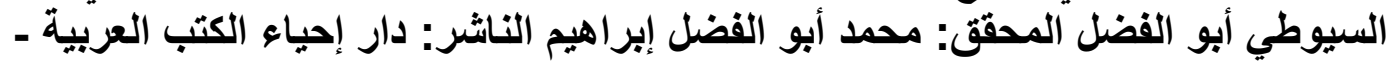

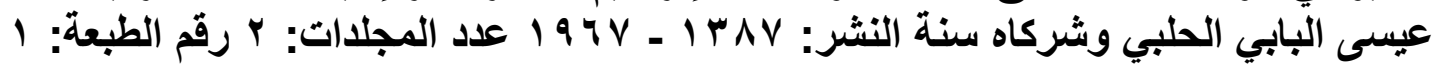

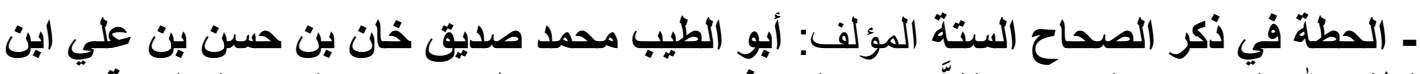

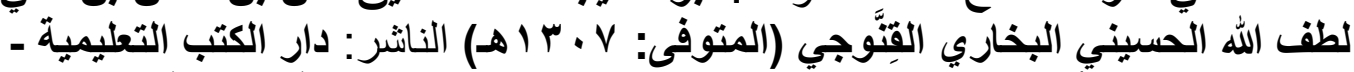

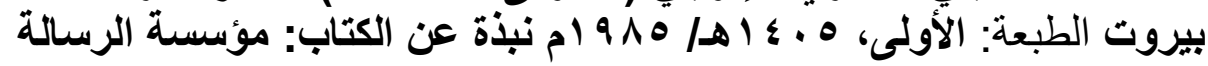

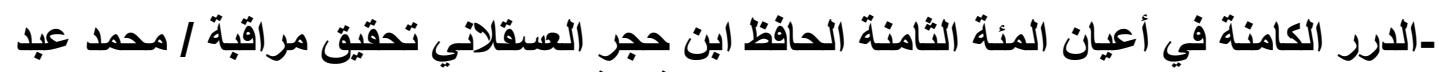

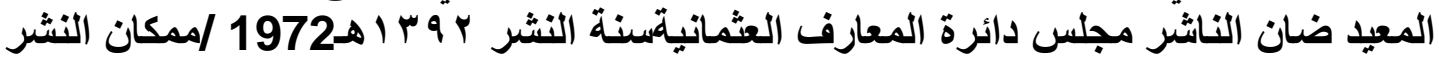

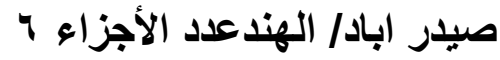

ـالايباج المذهب في معرفة علماء أعيان المذهب /المؤلف: ابن فرحون المالكي/المحقق:

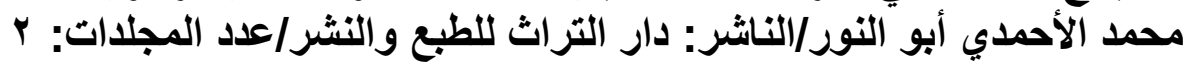

ـ ذكر من يعتمد قوله في الجرح والتعديل المؤلف : شمس الاين محمد بن أحمد الأهبي

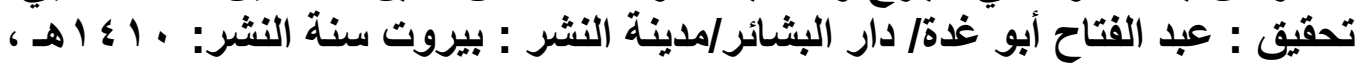
1990 ـالأيل والتكملة لكتابي الموصول والصلة|لمؤلف: ابن عبد الملك المراكثي (ت م . Vـر -رسالة المستطرفة لبيان مشهور كتب السنة المشرفة المؤلف: محمد بن جعفر بن إدريس

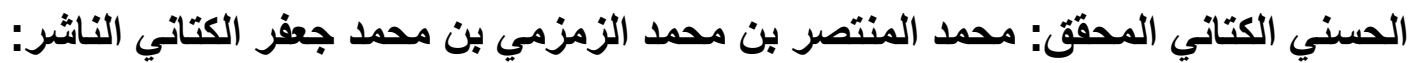

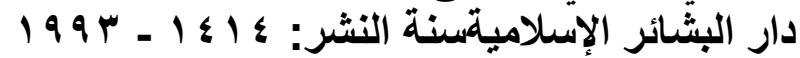

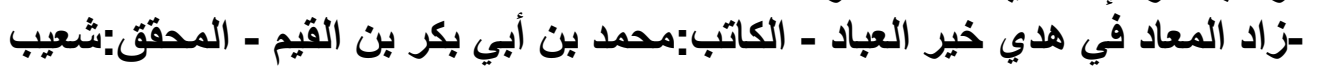

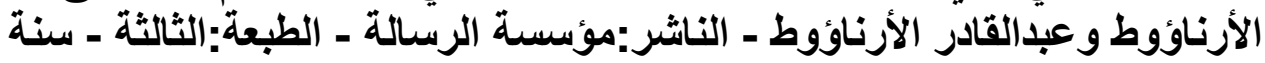

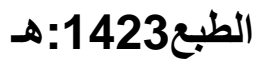

-سؤالات البرذعي لأبي زرعة الرازي ومعه كتاب أسامي الضعفاءالمؤلف: عبيد الله بن عبد

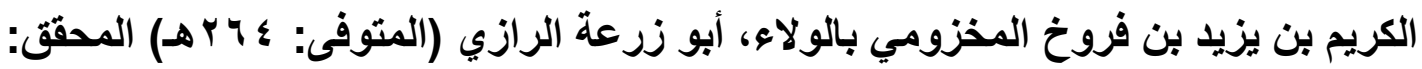

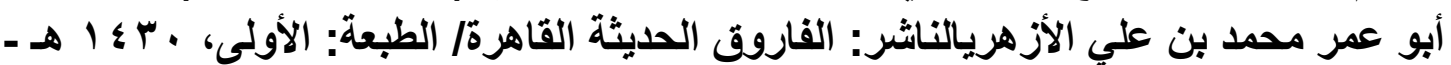

-سير أعلام النبلاء - الكاتب:محمد بن أحمد بن عثمان الذهبي - المحقق:بدون -

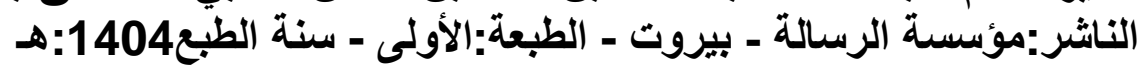

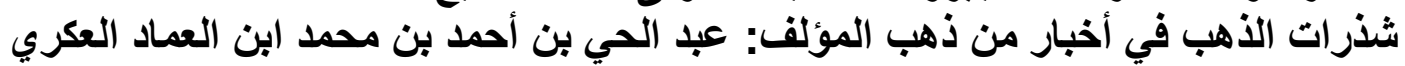

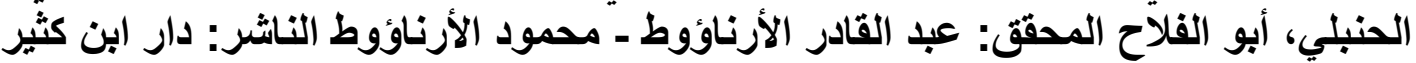

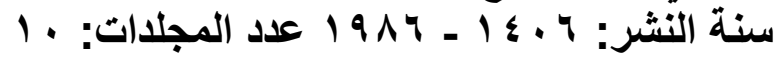

ـ شرح علل الترمذي - الكاتب:عبدالرحمن بن رجب الحنبلي - المحقى:نور الاين عتر -

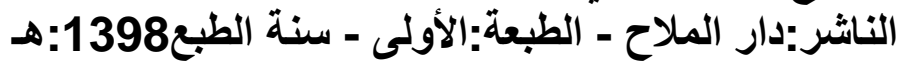

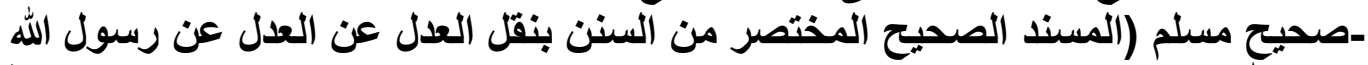

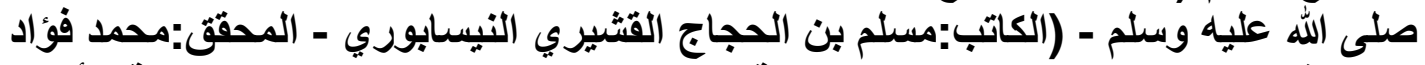
عبدالباقي - الناشر:دار إحياء الكتب العربية ـ عيسى البابي الحلبي وشُركاه ـ الطبعة:الأولى سنة الطبع1374:هـ 


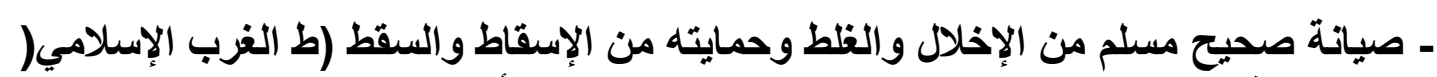

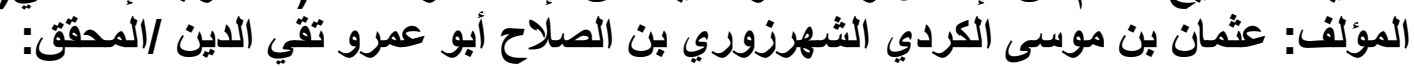

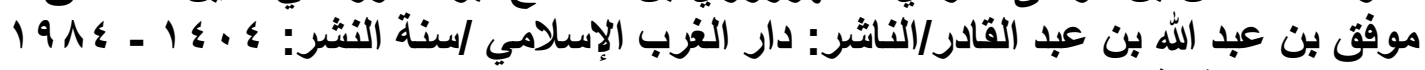

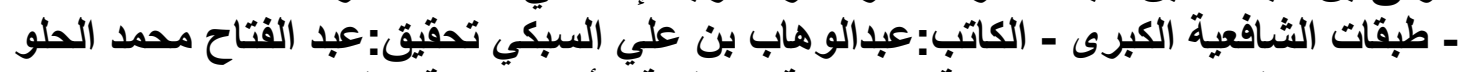

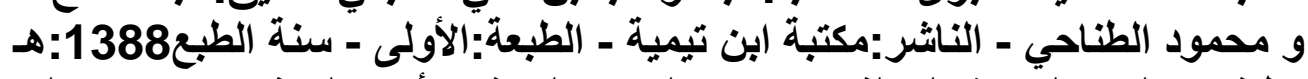

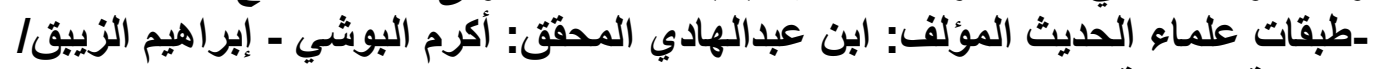
مؤسسة الرسائة؛

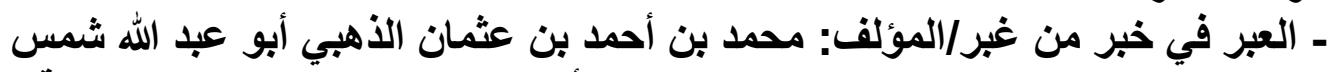

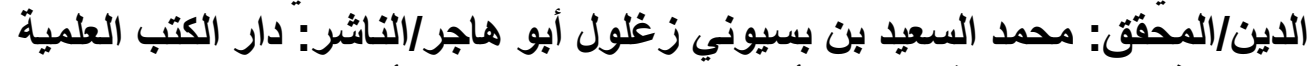

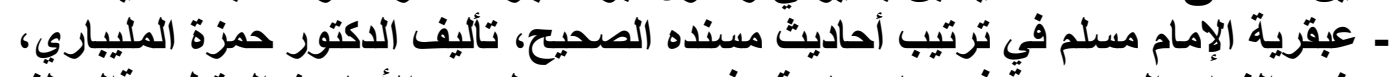

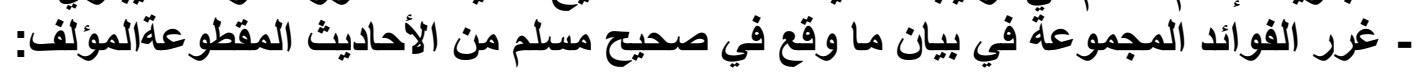

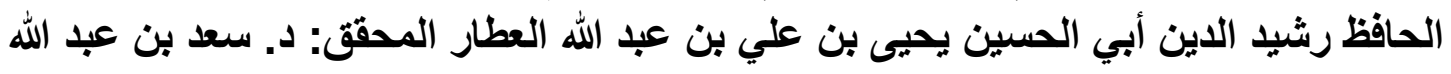

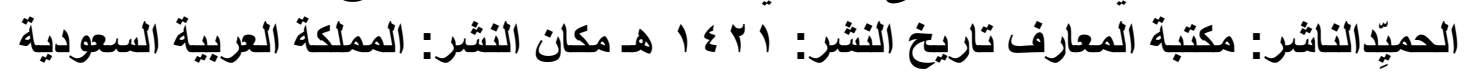

ـغنية المحتاج في ختم صحيح مسلم بن الحجاج - المؤلف :الحافظ أبو الخير محمد بن عبد الثبا.

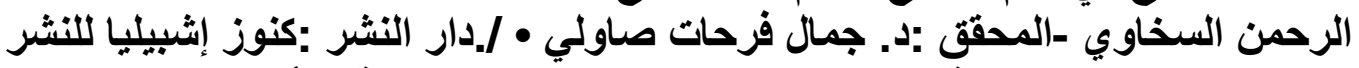

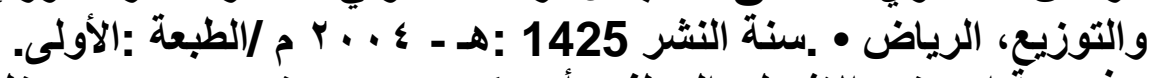

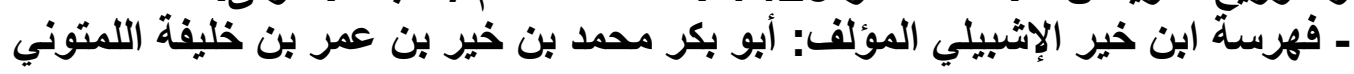

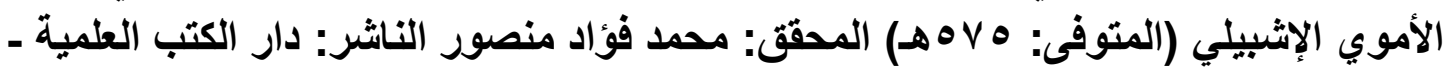

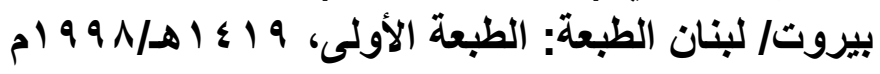

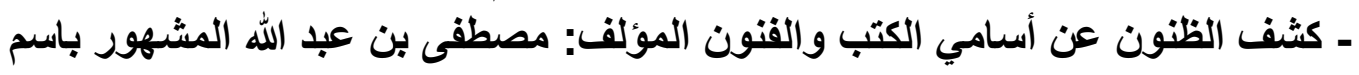

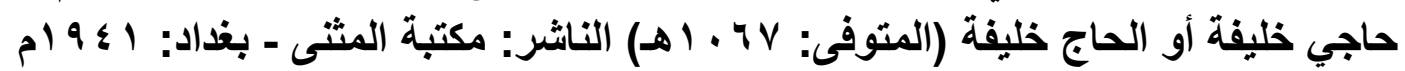

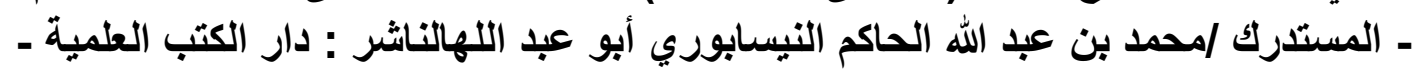

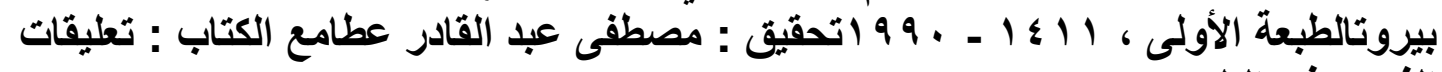

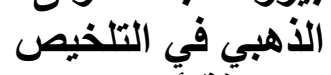

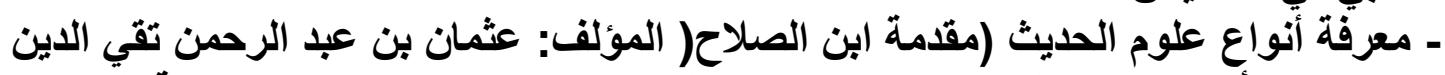

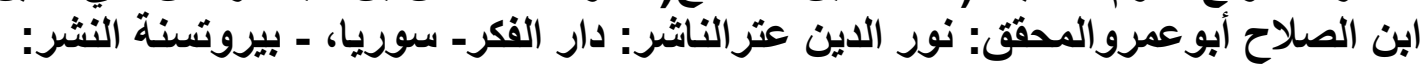

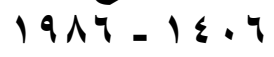

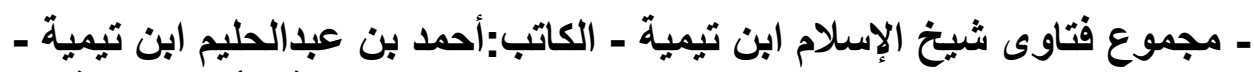

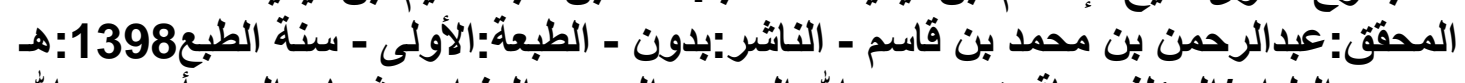

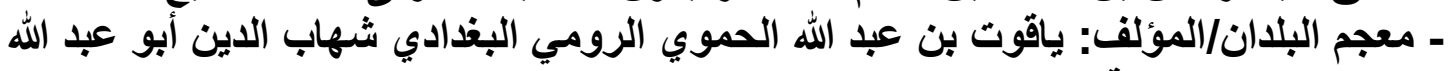

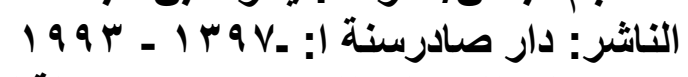

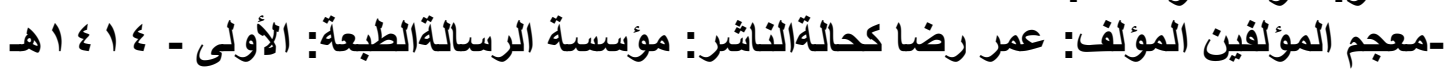

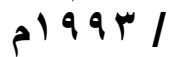
ـ المنهاج في شرح صحيح مسلم بن الحجاج (صحيح مسلم بشرح النووي) (ط المصرية

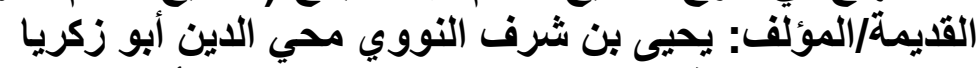

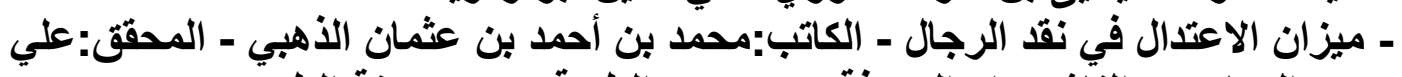

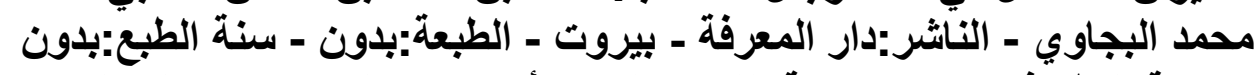

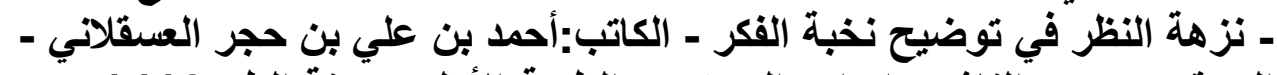

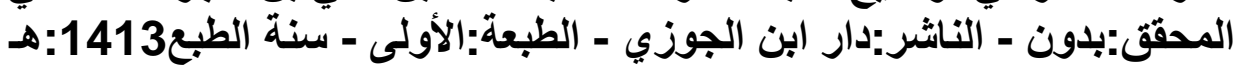




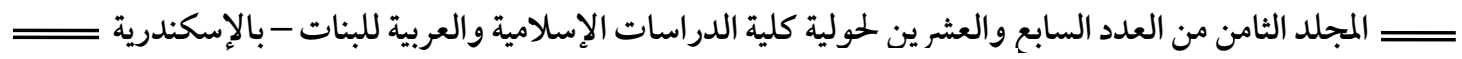
الإمام مسلم ومنهجه في صحيحه

- هدي الساري - الكاتب:أحمد بن علي بن حجر العسقلاني - المحقق:محب الدين الخطيب -

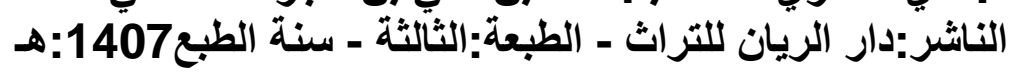

ـ هدية العارفين أسماء المؤلفين وآثار المصنفين - ويليه ذيل على كثف الظنون المؤلف:

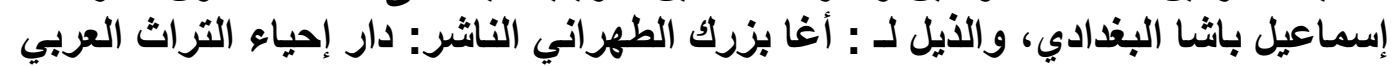

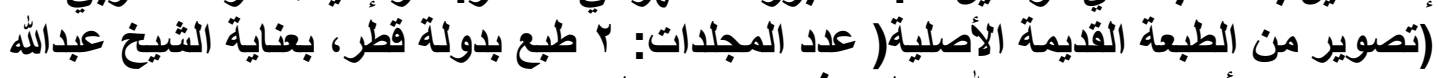

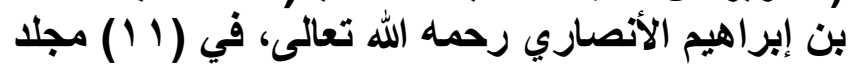

- وفيات الأعيان وأنباء أبناء الزمان - اسم المؤلف: أحمد بن محمد بن أبيب بكر بن خلكان

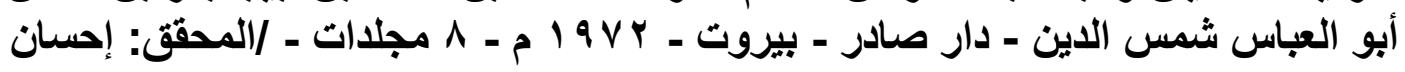
عباس 


\section{فهرس الموضوعات}

19.

191

$19 r$

190

199

$r \ldots$

$r \cdot 1$

$r \cdot \Lambda$

rYT

rrY

rry

$r \leq 1$

$r \leq Y$
المبحث الأول نبذة عن حياة الامام مسلم رحمه الله

المطلب الأول اسمه ونسبه ونشأته

المطلب الثاني سماعه للحديث وشيوخه وتلاميذه :

المطلب الثالث/ ثناء العلماء عليه وصفته الخلقية واهم ملامح شخصيته

المبحث الثاني منهج الامام مسلم في صحيحه

المطلب الأول أسماء صحيح مسلم

المطلب الثاني سبب تأليفه واهتمامه به و مكان تأليفه

المطلب الثالث خصائص صحيح مسلم المطلب الرابع شروح صحيح الإمام مسلم: المطلب الخامس : الانتقادات الموجه لصحيح مسلم والرد عليها: المطلب السادس:بحوث ودراسات حول صحيح مسلم. 